INSTYTUT EKONOMIKI ROLNICTWA I GOSPODARKI ŻYWNOŚCIOWEJ PAŃSTWOWY INSTYTUT BADAWCZY

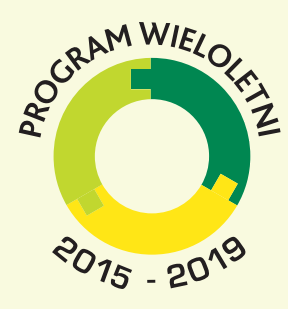

\title{
Konkurencyjność polskich producentów żywności \\ i jej determinanty \\ [3]
}

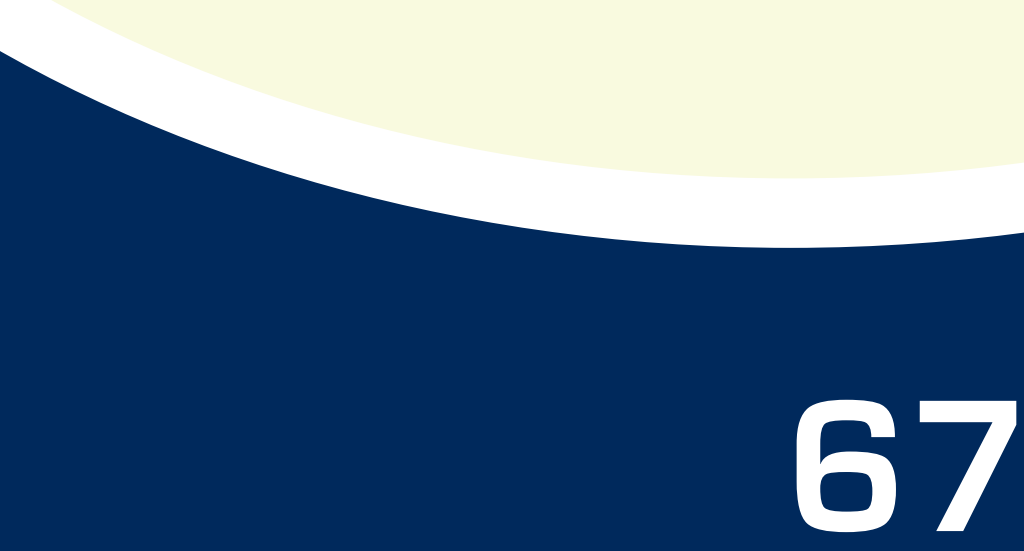

MONOGRAFIE

PROGRAMU WIELOLETNIEGO

WARSZAWA 2017 
Konkurencyjność polskich producentów żywności i jej determinanty

(3) 



\section{INSTYTUT EKONOMIKI ROLNICTWA I GOSPODARKI ŻYWNOŚCIOWEJ PAŃSTWOWY INSTYTUT BADAWCZY}

\section{Konkurencyjność polskich producentów żywności i jej determinanty (3)}

Redakcja naukowa dr Iwona Szczepaniak

Autorzy: dr Łukasz Ambroziak mgr Małgorzata Butkowska dr Katarzyna Kosior prof. dr hab. Henryk Runowski dr Iwona Szczepaniak mgr Mirosława Tereszczuk dr hab. Ludwik Wicki, prof. SGGW

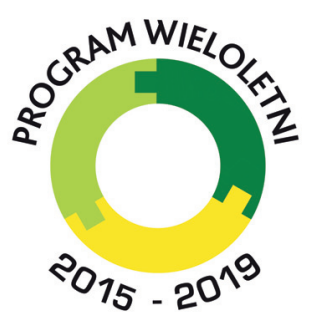

ROLNICTWO POLSKIE I UE 2020+ WYZWANIA, SZANSE, ZAGROŻENIA, PROPOZYCJE Warszawa 2017 
Prof. dr hab. Henryk Runowski i dr hab. Ludwik Wicki, prof. SGGW

są pracownikami Szkoły Głównej Gospodarstwa Wiejskiego w Warszawie.

Pozostali Autorzy publikacji są pracownikami Instytutu Ekonomiki Rolnictwa i Gospodarki Żywnościowej - Państwowego Instytutu Badawczego.

Pracę zrealizowano w ramach tematu

Ewolucja i perspektywy rynków rolno-spożywczych

w zadaniu Konkurencyjność polskich producentów żywności i jej determinanty.

Celem pracy jest ocena konkurencyjności polskich producentów żywności i jej wybranych determinant.

Recenzenci:

dr hab. Krzysztof Firlej, prof. Uniwersytetu Ekonomicznego w Krakowie dr hab. Karolina Pawlak, prof. Uniwersytetu Przyrodniczego w Poznaniu

Opracowanie komputerowe

Anna Staszczak

Korekta

Barbara Pawłowska

Redakcja techniczna

Leszek Ślipski

Projekt okładki

Leszek Ślipski

ISBN 978-83-7658-709-7

DOI: $10.30858 / \mathrm{pw} / 9788376587097$

Instytut Ekonomiki Rolnictwa i Gospodarki Żywnościowej

- Państwowy Instytut Badawczy

ul. Świętokrzyska 20, 00-002 Warszawa

tel.: (22) 5054444

faks: (22) 5054757

e-mail:dw@ierigz.waw.pl

http://www.ierigz.waw.pl 


\section{Spis treści}

Wstęp 7

dr Iwona Szczepaniak

1. Wpływ uwarunkowań makroekonomicznych, politycznych i społecznych na konkurencyjność sektora żywnościowego w Polsce w kontekście procesów globalnych..........................................................................9 dr Katarzyna Kosior

1.1. Wprowadzenie

1.2. Główne czynniki wpływające na konkurencyjność gospodarki z perspektywy konkurencyjności systemowej

1.3. Globalizacja, integracja i dezintegracja? Dynamika zmian w otoczeniu międzynarodowym 16

1.4. Krajowe uwarunkowania konkurencyjności sektora żywnościowego .23

1.5. Podsumowanie 41

2. Przewagi komparatywne w polskim handlu produktami rolno-spożywczymi.... 45 dr Iwona Szczepaniak

2.1. Wprowadzenie 45

2.2. Uwagi metodyczne 48

2.3. Wyniki handlu zagranicznego produktami rolno-spożywczymi Polski na wybranych rynkach

2.4. Ocena przewag komparatywnych w handlu produktami rolno-spożywczymi Polski na wybranych rynkach.... 66

2.5. Podsumowanie 80

3. Ceny relatywne w polskim eksporcie produktów rolno-spożywczych do krajów Unii Europejskiej dr Łukasz Ambroziak

3.1. Wprowadzenie

3.2. Koncepcja zastosowania wartości jednostkowych w badaniach jakości produktów 82

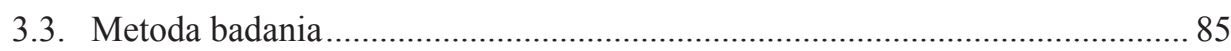

3.4. Analiza cen relatywnych w polskim eksporcie do Unii Europejskiej .............. 88

3.5. Podsumowanie 105 


\section{Umowy o wolnym handlu UE z Ukrainą, Gruzją i Mołdawią}

a konkurencyjność polskich producentów żywności.

mgr Małgorzata Bułkowska

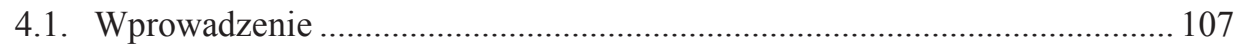

4.2. Handel rolno-spożywczy Polski z Ukrainą, Mołdawią i Gruzją .................... 108

4.3. Bariery w handlu Unii Europejskiej, Ukrainy, Gruzji i Mołdawii ................. 114

4.4. Wpływ umów na konkurencyjność polskich producentów żywności........... 127

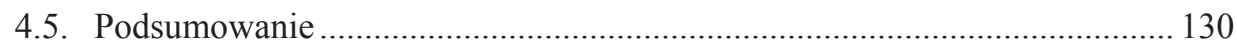

5. Działalność promocyjna jako czynnik konkurencyjności

polskich producentów żywności ....................................................................... 132

mgr Mirosława Tereszczuk

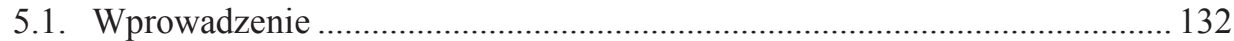

5.2. Działania promocyjne, ich funkcje, znaczenie oraz cele.............................. 133

5.3. Wybrane instrumenty promocji i ich oddziaływanie na odbiorców ............... 138

5.4. Promocja produktów rolno-spożywczych a Wspólna Polityka Rolna .......... 141

5.5. Działania promocyjne $\mathrm{i}$ informacyjne wspierające polskich producentów żywności ....................................................................... 144

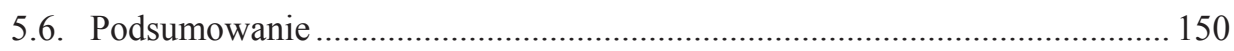

6. Postęp biologiczny w rolnictwie i jego wpływ na konkurencyjność producentów rolnych.

prof. dr hab. Henryk Runowski, dr hab. Ludwik Wicki, prof. SGGW

6.1. Wprowadzenie

6.2. Uwarunkowania wzrostu zapotrzebowania na żywność i pokrycia potrzeb żywnościowych

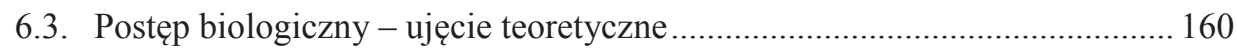

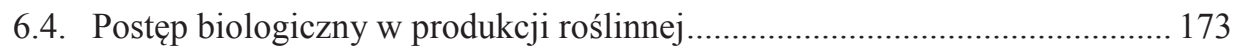

6.5. Postęp biologiczny w produkcji zwierzęcej ................................................. 190

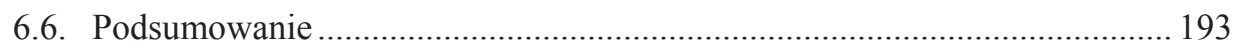

Zakończenie ......................................................................................................................... 198

dr Iwona Szczepaniak

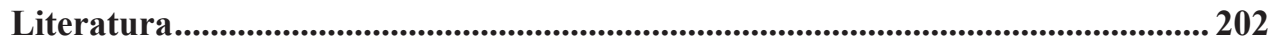




\section{Wstęp}

Przekazujemy do Państwa rąk trzecią monografię opracowaną w ramach zadania badawczego „Konkurencyjność polskich producentów żywności i jej determinanty”. Zadanie to, będąc częścią tematu badawczego „Ewolucja i perspektywy rynków rolno-spożywczych”, realizowane jest w Instytucie Ekonomiki Rolnictwa i Gospodarki Żywnościowej - Państwowym Instytucie Badawczym (IERiGŻ-PIB) w ramach Programu Wieloletniego „Rolnictwo polskie i UE 2020+. Wyzwania, szanse, zagrożenia, propozycje”. Badania objęte tym Programem będą kontynuowane do 2019 roku włącznie.

Zadanie „Konkurencyjność polskich producentów żywności i jej determinanty” jest kontynuacją zadania „Ocena zmian konkurencyjności polskich producentów żywności na Wspólnym Rynku Europejskim i na rynkach innych krajów” oraz zadania „Monitoring stanu konkurencyjności polskich producentów żywności", realizowanych w IERiGŻ-PIB w ramach Programów Wieloletnich w latach 2005-2009 oraz 2011-2014 .

Przeobrażenia zachodzące na rynku światowym, w tym przede wszystkim rozwój procesów globalizacji, integracji i liberalizacji gospodarek, otwarcie nowych rynków oraz intensyfikacja handlu światowego spowodowały zmianę charakteru, intensywności i zasięgu konkurencji. Rywalizacja nie ma już wyłącznie charakteru krajowego, ale coraz częściej odbywa się w wymiarze międzynarodowym. Poszczególne podmioty konkurują zarówno z krajowymi, jak i z zagranicznymi jednostkami. Specyfika uwarunkowań rynkowych powoduje, że nawet podmioty, które nie uczestniczą aktywnie w procesie internacjonalizacji, tzn. nie realizują żadnego rodzaju działalności gospodarczej za granicą, zmuszone są konkurować z zagranicznymi konkurentami. Dzieje się tak dlatego, że krajowy rynek jest rynkiem otwartym, na którym krajowi producenci współistnieją z producentami z innych krajów. Na poziomie mikro- i mezoekonomicznym oznacza to możliwość zdobywania nowych rynków zbytu i dynamicznego rozwoju handlu zagranicznego, a w efekcie ogólnego rozwoju ekonomicznego przedsiębiorstw i sektorów. Z drugiej jednak strony międzynarodowy wymiar konkurencji sprawia, że podmioty stają wobec bardzo wielu nowych wyzwań, a warunki, w jakich funkcjonują, są coraz trudniejsze.

Niniejsza monografia stanowi próbę wieloaspektowego spojrzenia na zagadnienie konkurencyjności polskich producentów żywności. Składa się z sześciu

\footnotetext{
${ }^{1}$ Wszystkie monografie opublikowane w ramach wymienionych zadań z Programów Wieloletnich są dostępne na stronie internetowej IERiGŻ-PIB: https://www.ierigz.waw.pl/.
} 
rozdziałów. W pierwszym z nich (autor: dr Katarzyna Kosior) scharakteryzowano najważniejsze uwarunkowania o charakterze ekonomicznym, politycznym i społecznym, które oddziałują na gospodarkę żywnościową w Polsce, starając się wskazać główne wyzwania oraz zarówno te czynniki, które mają pozytywny wpływ na konkurencyjność, jak i te, które mogą hamować dalszy wzrost konkurencyjności polskiego sektora żywnościowego.

Drugi rozdział (autor: $d r$ Iwona Szczepaniak) zawiera analizę przewag komparatywnych w polskim handlu rolno-spożywczym na wybranych rynkach (na rynku światowym, rynku państw UE-15 i UE-13 oraz rynku krajów spoza UE). Wyniki przeprowadzonego rachunku można traktować jako przybliżoną ocenę zdolności sektora do konkurowania na rynku międzynarodowym, a jednocześnie podstawę do oceny jego międzynarodowej pozycji konkurencyjnej. W badaniu wykorzystano wskaźnik relatywnej przewagi w handlu (RTA).

W trzecim rozdziale (autor: dr Łukasz Ambroziak) starano się odpowiedzieć na pytanie, czy międzynarodowa konkurencyjność polskiego sektora rolno-spożywczego w państwach Unii Europejskiej opierała się dotychczas bardziej na niższych kosztach produkcji, które umożliwiały oferowanie niższych cen produktów, czy na pozacenowych instrumentach konkurowania, w tym na szeroko rozumianej jakości produktów. Na potrzeby badania zastosowano jedną z metod badania konkurencyjności cenowo-jakościowej, tj. wskaźnik cen relatywnych w eksporcie (RC).

Rozdział czwarty (autor: mgr Matgorzata Bułkowska) odnosi się do zewnętrznych determinant konkurencyjności. Jego celem była próba oceny wpływu zawarcia przez Unię Europejską umów DCFTA (Deep and Comprehensive Free Trade Agreement - Porozumienie o pogłębionej i całościowej strefie wolnego handlu) z Ukrainą, Mołdawią i Gruzją na handel rolno-spożywczy Polski, w tym na konkurencyjność polskich producentów żywności na tych rynkach.

W rozdziale piątym (autor: $m g r$ Mirosława Tereszczuk) zwrócono z kolei uwagę na jeden z wewnętrznych czynników konkurencyjności, a mianowicie działania promocyjne prowadzone w obszarze gospodarki żywnościowej, zarówno te realizowane przez podmioty sektora, jak i te w ramach Wspólnej Polityki Rolnej.

Rozdział szósty (autorzy: prof. dr hab. Henryk Runowski, dr hab. Ludwik Wicki, prof. $S G G W$ ) przedstawia pogłębioną analizę postępu biologicznego w rolnictwie (w produkcji roślinnej i zwierzęcej), a także próbę oceny możliwości kreowania dodatkowych przewag konkurencyjnych producentów rolnych w związku z wprowadzaniem postępu biologicznego. 


\section{Wpływ uwarunkowań makroekonomicznych, politycznych i społecznych na konkurencyjność sektora żywnościowego w Polsce w kontekście procesów globalnych}

\subsection{Wprowadzenie}

Gwałtowny postęp technologiczny, zmiany demograficzne, zmiany klimatu, zmieniające się wzorce konsumpcji i oczekiwania konsumentów tworzą nowe ramy rozwoju gospodarki żywnościowej na świecie. Z jednej strony, w związku z rosnącą liczbą ludności na świecie, pojawia się presja na zwiększanie produktywności oraz wielkości produkcji rolnej i artykułów spożywczych. Z drugiej strony rosną oczekiwania dotyczące jakości żywności, jej bezpieczeństwa i przejrzystości funkcjonowania łańcuchów żywnościowych. W krajach najbardziej rozwiniętych można mówić o kształtowaniu się nowego paradygmatu rozwoju gospodarki żywnościowej, bazującego na bardziej niż kiedykolwiek w przeszłości rozwiniętej świadomości konsumenckiej. Oczekuje się, że sektor żywnościowy będzie dostarczać produkty, które nie tylko zaspokoją potrzeby fizjologiczne konsumentów, ale również będą pozytywnie wpływać na ich zdrowie. Dzięki powszechnemu dostępowi do Internetu i masowej komunikacji w skali globalnej trendy żywnościowe rozprzestrzeniają się obecnie bardzo szybko, decydując niejednokrotnie o kierunkach i perspektywach rozwoju konkretnych branż i podmiotów sektora rolno-spożywczego.

Dynamika procesów globalizacji prowadzi z jednej strony do rosnącej współzależności gospodarek żywnościowych poszczególnych państw, z drugiej wskazuje nowe kierunki i możliwości rozwoju rolnictwa i całego łańcucha żywnościowego. Doświadczenia globalnego kryzysu finansowego lat 2008-2009, a w szczególności negatywne skutki gospodarcze, społeczne i polityczne dużej zmienności cen artykułów rolnych, zmieniły podejście decydentów do gospodarki żywnościowej i polityki rolnej. Można mówić o większej niż poprzednio świadomości wagi rolnictwa i żywności w agendzie rozwojowej, a także o większej świadomości potrzeby inwestowania $\mathrm{w}$ ten relatywnie słabiej rozwinięty sektor gospodarki ${ }^{2}$. Inwestycjami w sektor rolno-spożywczy w coraz większym stopniu zainteresowane są również podmioty gospodarcze $\mathrm{z}$ sektorów i branż nowoczesnych technologii informacyjno-komunikacyjnych, które dotąd nie były kojarzone ani z rolnictwem, ani z przemysłem spożywczym. W najbardziej

\footnotetext{
${ }^{2}$ A. Kowalski, Rolnictwo wobec wyzwań globalizacji, [w:] I. Szczepaniak i K. Firlej (red.), Przemyst spożywczy - makrootoczenie, inwestycje, ekspansja zagraniczna, Wydawnictwo Fundacja Uniwersytetu Ekonomicznego w Krakowie, IERiGŻ-PIB, Kraków-Warszawa 2015, s. 13.
} 
zaawansowanych gospodarczo i technologicznie państwach świata przygotowywane są obecnie strategie cyfryzacji rolnictwa i łańcuchów żywnościowych, które mają prowadzić do większej produktywności w tym sektorze bez generowania negatywnych konsekwencji dla środowiska naturalnego.

W związku z nowymi wyzwaniami i dynamicznymi zmianami w środowisku zewnętrznym coraz większego znaczenia nabierają pytania o czynniki, które decydować będą o pozycji i zdolności konkurencyjnej polskiej gospodarki żywnościowej w przyszłości. Ostatnie dekady upływające pod znakiem transformacji gospodarczej i integracji z UE stworzyły odpowiednie warunki dla dynamicznego rozwoju sektora żywnościowego w Polsce. Włączenie rolnictwa do mechanizmów Wspólnej Polityki Rolnej UE doprowadziło do przyspieszenia procesów modernizacji gospodarstw rolnych i poprawy sytuacji dochodowej polskich rolników ${ }^{3}$. Stosunkowo wolne tempo przeobrażeń strukturalnych mimo wszystko ograniczało perspektywy wzmacniania potencjału konkurencyjnego rolnictwa ${ }^{4}$. Z drugiej strony kluczowy w łańcuchu żywnościowym przemysł spożywczy stał się jednym z najszybciej rozwijających się sektorów polskiej gospodarki. W rezultacie Polska znalazła się na pierwszym miejscu na liście głównych producentów żywności w krajach UE-13 (krajach, które przystąpiły do UE po 2004 roku) i na szóstym miejscu wśród państw UE-28, po: Niemczech, Włoszech, Francji, Wielkiej Brytanii i Hiszpanii ${ }^{5}$. W okresie od 2004 do 2016 roku eksport żywności zwiększył się czterokrotnie - do 25,5 mld USD, a import przeszło trzykrotnie (do 17,7 mld USD), co oznaczało, że sektor rolno-spożywczy był w tym okresie jednym z niewielu sektorów polskiej gospodarki o dodatnim saldzie wymiany handlowej ${ }^{6}$. Coraz częściej pojawiają się jednak wątpliwości, czy dotychczasowe strategie rozwoju pozwolą polskiemu sektorowi rolno-spożywczemu utrzymać dobrą pozycję konkurencyjną na rynkach międzynarodowych w średnim i dłuższym horyzoncie czasowym. Wiele wskazuje na to, że w kolejnych latach rola niektórych czynników, które jeszcze niedawno pozytywnie oddziaływały na osiągane wyniki i pozycję konkurencyjną sektora żywnościowego, takich jak m.in. niskie koszty pracy, będzie maleć. Zmieniają się bowiem nie

\footnotetext{
${ }^{3} \mathrm{~W}$. Rembisz, Identyfikacja procesów wzrostowych w sektorze rolno-spożywczym, seria „Monografie Programu Wieloletniego 2015-2019”, nr 22.1, IERiGŻ-PIB, Warszawa 2015, s. 112-113.

${ }^{4}$ A. Sikorska (red.), Kierunki przeobrażeń strukturalnych oraz uwarunkowania rozwoju rolnictwa i obszarów wiejskich, seria „Monografie Programu Wieloletniego 2015-2019”, nr 18, IERiGŻ-PIB, Warszawa 2015, s. 127-128.

${ }^{5}$ J. Drożdż, R. Mroczek, M. Tereszczuk, Rozwój przemystu spożywczego w Polsce i innych krajach Unii Europejskiej, [w:] R. Mroczek (red.), Przemiany strukturalne przemystu spożywczego w Polsce i UE na tle wybranych elementów otoczenia zewnętrznego, seria „Monografie Programu Wieloletniego 2015-2019”, nr 12, IERiGŻ-PIB, Warszawa 2015, s. 104.

${ }^{6}$ Zob. rozdział 2, s. 54-55, 59.
} 
tylko szersze uwarunkowania związane $\mathrm{z}$ funkcjonowaniem międzynarodowych reżimów handlowych, ale również ogólne podejścia do budowania przewag konkurencyjnych w związku z postępującą w skali globalnej digitalizacją i technologizacją życia gospodarczego i społecznego.

Celem rozdziału jest przybliżenie dynamiki zmian w otoczeniu międzynarodowym oraz nakreślenie ogólnych ram i uwarunkowań o charakterze ekonomicznym, politycznym i społecznym, oddziałujących na gospodarkę żywnościową w Polsce, z zamiarem wskazania głównych wyzwań i tych czynników, które mają pozytywny wpływ na konkurencyjność oraz tych, które mogą hamować dalszy rozwój i wzrost konkurencyjności polskiego sektora żywnościowego.

Konkurencyjność można rozumieć i oceniać z różnych perspektyw oraz $\mathrm{z}$ zastosowaniem różnych ujęć ${ }^{7}$. W rozdziale uwaga skoncentrowana zostanie na ocenie perspektyw rozwoju potencjału konkurencyjnego sektora żywnościowego w Polsce. Zastosowana metodologia nawiązuje do perspektywy konkurencyjności systemowej (systemic competitiveness), która pozwala na stosunkowo szeroką i przekrojową ocenę różnych czynników wpływających na i określających zdolność konkurencyjną gospodarki narodowej, jej sektorów i przedsiębiorstw. Rozważania dotyczyć będą dwóch kluczowych ogniw łańcucha żywnościowego rolnictwa i przemysłu spożywczego. Struktura rozdziału jest następująca: w drugiej jego części zaprezentowane zostaną główne determinanty konkurencyjności z perspektywy konkurencyjności systemowej; trzecia część obejmować będzie międzynarodowe uwarunkowania konkurencyjności; w czwartej części znajdzie się właściwa analiza potencjału konkurencyjnego polskiego sektora żywnościowego uporządkowana zgodnie z podejściem systemowym; rozdział zakończy podsumowanie wraz z wnioskami.

\subsection{Główne czynniki wpływające na konkurencyjność gospodarki z perspektywy konkurencyjności systemowej}

Podejście systemowe do badania konkurencyjności zaproponowali w połowie lat 90. ubiegłego wieku ekonomiści Niemieckiego Instytutu Polityki Rozwoju - K. Esser i in. ${ }^{8}$ Analizy sytuacji międzynarodowej oraz funkcjonowania przedsiębiorstw na rynkach międzynarodowych w warunkach szybkich zmian technologicznych i organizacyjnych doprowadziły autorów tego podejścia do przekonania, że kluczowe dla budowania systemowej (strukturalnej) konkurencyjności gospodarek są działania podejmowane na wszystkich poziomach orga-

\footnotetext{
${ }^{7}$ Ibid., s. 33.

${ }^{8}$ K. Esser i in., Systemic competitiveness: new governance patterns for industrial development, GDI/Frank Cass, London 1996.
} 
nizujących i strukturyzujących życie społeczno-polityczne i gospodarcze w państwie. Konkurencyjność nie jest zjawiskiem, które pojawia się automatycznie i samorzutnie - jako np. efekt zmian wyłącznie w środowisku makroekonomicznym, czy też efekt przedsiębiorczości na poziomie mikroekonomicznym. Jest to raczej efekt złożonych i dynamicznych interakcji między rządem, firmami, instytucjami pośredniczącymi i zdolnościami organizacyjnymi społeczeństwa ${ }^{9}$. Konkurencyjność gospodarki, zgodnie z tym podejściem, opiera się więc zarówno na ukierunkowanych oraz wzajemnie powiązanych działaniach na czterech poziomach - meta, makro, mezo i mikro, jak i na wielowymiarowym i angażującym najważniejsze grupy podmiotów procesie kontroli i sterowania rozwojem w oparciu o konkurencję, dialog i wspólne podejmowanie decyzji ${ }^{10}$.

Pełniejsze zrozumienie konkurencyjności i perspektyw jej rozwoju wymaga więc w pierwszym rzędzie uwzględnienia różnych czynników o charakterze przyczynowym, które ulokowane są na poziomach meta, makro, mezo i mikro. Równocześnie, wobec przyspieszających procesów globalizacji, niezbędne jest uwzględnienie zmian w otoczeniu międzynarodowym, które nie tylko wpływają na ogólne warunki konkurencji, ale równocześnie określają wagę i rolę poszczególnych czynników ulokowanych na czterech poziomach konkurencyjności systemowej. Celem działań w tak złożonym środowisku międzynarodowym i krajowym powinno być przekształcanie przewag komparatywnych w przewagi konkurencyjne $^{11} \mathrm{w}$ oparciu o działania prowadzące do wzrostu produktywności czynników produkcji. Produktywność bardzo często wykorzystywana jest w analizach ekonomicznych jako jeden z najważniejszych mierników konkurencyjności. Również w ujęciu systemowym wzrost lub spadek konkurencyjności wiązany jest ze wzrostem lub spadkiem produktywności, mierzonej najczęściej za pomocą PKB na mieszkańca, produktywnością pracy czy techniczną wydajnością, definiowaną przez produktywność wieloczynnikową. Autorzy podejścia systemowego

\footnotetext{
${ }^{9}$ Ibid., s. 27.

${ }^{10}$ Ibid., s. 28.

${ }^{11}$ Pojęcie przewagi komparatywnej dotyczy sytuacji, w której podmioty (przedsiębiorstwa, sektory, gospodarki) są w stanie wytwarzać dane dobra po niższym koszcie względnym niż podmioty z nimi konkurujące. Jako taka przewaga komparatywna może decydować o posiadaniu przewag konkurencyjnych. Źródłem przewag konkurencyjnych mogą być jednak również inne czynniki i uwarunkowania związane $\mathrm{z}$ funkcjonowaniem danego podmiotu $\mathrm{w}$ otoczeniu społeczno-gospodarczym, m.in. dostęp do wykwalifikowanej siły roboczej, sprawność organizacyjna przedsiębiorstwa, wysoka jakość produkcji, umiejętność zarządzania wiedzą i innowacjami, czy umiejętność budowania relacji z otoczeniem. O zmieniających się źródłach przewag konkurencyjnych w świecie nowoczesnych technologii piszą m.in. M.E. Porter i J.E. Heppelmann, How smart, connected products are transforming competition, „Harvard Business Review" 2014, vol. 92(11), s. 64-88.
} 


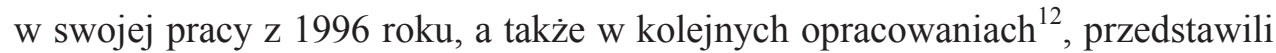
główne czynniki na każdym z wyodrębnionych poziomów, które można łączyć ze wzrostem bądź ze spadkiem produktywności, a zatem i ze zmianami konkurencyjności. W uproszczonej wersji poziomy konkurencyjności systemowej oraz jej główne determinanty zaprezentowane zostały na rysunku 1.1.

Rysunek 1.1. Poziomy konkurencyjności systemowej w warunkach globalizacji

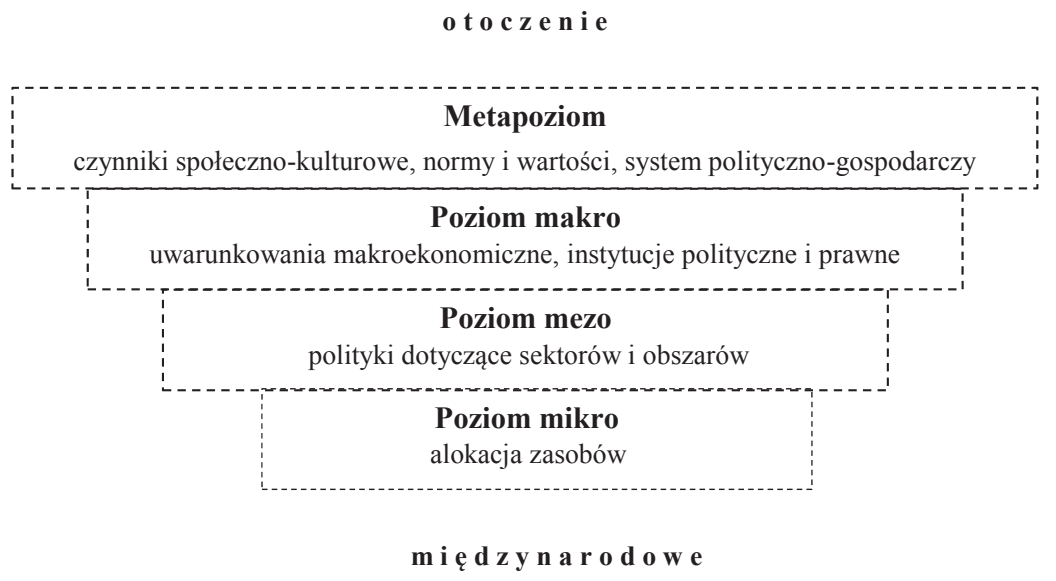

Źródlo: opracowanie wlasne na podstawie K. Esser i in., Systemic competitiveness: new governance patterns for industrial development, GDI/Frank Cass, London 1996; D. Messner, The Network Society: Economic Development and International Competitiveness as Problems of Social Governance, Routledge, 2013; J. Meyer-Stamer, Systemic Competitiveness, http://www.meyer-stamer.de/systemic.html.

Pierwszym kluczowym dla konkurencyjności poziomem jest poziom meta. Uwarunkowania na tym poziomie obejmują czynniki społeczno-kulturowe oraz normy i wartości, które sterują podstawowymi wyborami społecznymi oraz wpływają na system organizacji polityczno-gospodarczej w danym państwie ${ }^{13}$. Czynniki te kształtują tak fundamentalne dla konkurencyjności gospodarki, jej sektorów oraz przedsiębiorstw obszary, jak podejście do przedsiębiorczości, poziom kapitału społecznego, zdolność do współpracy i wzajemnego uczenia się, gotowość do dzielenia się wiedzą, postrzeganie osiągnięć innych, otwartość na zmiany i innowacje. Kształtowany przez czynniki tego poziomu system polityczny i gospodarczy może być też albo otwarty i zorientowany na konkuren-

\footnotetext{
${ }^{12}$ D. Messner, The Network Society: Economic Development and International Competitiveness as Problems of Social Governance, Routledge, 2013; J. Meyer-Stamer, Systemic Competitiveness, http://www.meyer-stamer.de/systemic.html (dostęp: 10.10.2017).

${ }^{13}$ D. Messner, The Network Society..., op. cit., s. 10.
} 
cję (zarówno między firmami, jak i między ugrupowaniami politycznymi) albo zamknięty, nastawiony na klientelizm i protekcjonizm w międzynarodowych relacjach gospodarczych. Czynniki tego poziomu decydują także o tym, czy podmioty posiadają umiejętność tworzenia strategii i polityk, w tym także umiejętność dobrego rządzenia. Konkurencyjność międzynarodowa pojawia się tylko w tych społeczeństwach, które politykę na rzecz konkurencyjności opierają na trwałym konsensusie oraz wspólnie wypracowanych i dopasowanych do potrzeb strategiach ${ }^{14}$.

W dalszej kolejności na konkurencyjność wpływają czynniki na poziomie makro - uwarunkowania makroekonomiczne, polityczne i prawne. Wśród kluczowych polityk na tym poziomie wymienić należy politykę budżetową, fiskalną, pieniężną, walutową, handlową oraz politykę ochrony konkurencji. Kluczowa dla utrzymania i wzrostu konkurencyjności gospodarki, jej sektorów i przedsiębiorstw pozostaje stabilność makroekonomiczna, oznaczająca utrzymywanie inflacji, deficytu budżetowego, kursu wymiany walut i zadłużenia publicznego w ramach, którymi można zarządzać ${ }^{15}$. Obok stabilnej polityki makroekonomicznej fundamentalne znaczenie dla konkurencyjności ma stabilność instytucji politycznych, zaufanie do państwa i jego agend oraz efektywny system egzekwowania prawa, m.in. antymonopolowego. Liczne badania wskazują na bardzo mocną zależność między stabilnymi i efektywnymi instytucjami a wzrostem produktywności i konkurencyjności gospodarek narodowych ${ }^{16}$. Stabilne makrootoczenie tworzy bezpieczne ramy dla inwestycji i zachęca do podejmowania nowych inicjatyw rozwojowych. Równie ważna - obok stabilności - jest jakość regulacji i ogólnych polityk państwa.

Stabilność na poziomie makro jest koniecznym warunkiem rozwoju konkurencyjności, jednak niewystarczającym. Równie istotne są odpowiednio zaprojektowane polityki na poziomie mezo. Polityki i działania ulokowane na tym poziomie dedykowane są konkretnym sektorom, obszarom funkcjonowania państwa czy też zagadnieniom społeczno-gospodarczym. Ich pojawienie się jest najczęściej efektem reakcji państwa na problemy stałej lub czasowej zawodności rynku w określonych obszarach. Chodzi tu o takie polityki, jak m.in.: polityka

\footnotetext{
${ }^{14}$ K. Esser i in., Systemic competitiveness..., op. cit., s. 29.

${ }^{15}$ D. Messner, The Network Society..., op. cit., s. 12.

${ }^{16}$ M. Olson, N. Sarna, A.V. Swamy, Governance and growth: A simple hypothesis explaining cross-country differences in productivity growth, „Public Choice” 2000, t. 102, nr 3-4, s. 341-364; D. Rodrik, A. Subramanian, F. Trebbi, Institutions rule: the primacy of institutions over geography and integration in economic development, „Journal of Economic Growth” 2004, t. 9, nr 2, s. 131-165; D. Acemoglu, S. Johnson, J.A. Robinson, Institutions as a fundamental cause of long-run growth, [w:] P. Aghion i S.N. Durlauf (red.), Handbook of Economic Growth 1, Elsevier 2005, s. 385-472.
} 
przemysłowa, regionalna, w zakresie infrastruktury, środowiskowa, edukacyjna, badań i rozwoju, technologiczna ${ }^{17}$. Duże znaczenie dla rozwoju konkurencyjności ma też polityka handlowa wobec pozostałych partnerów, prowadząca do ograniczenia ochrony rynku wewnętrznego przed importem. W takim otoczeniu podmioty gospodarcze otrzymują jasne sygnały wskazujące na konieczność zbliżania się do międzynarodowych poziomów wydajności. W przypadku analiz konkurencyjności sektora rolno-spożywczego kluczowe jest uwzględnienie dodatkowo polityki rolnej ze względu na jej bezpośrednie oddziaływanie na sektor.

Ostateczne wyniki w zakresie konkurencyjności zależą od zachowań i działań podejmowanych przez przedsiębiorstwa i inne podmioty na poziomie mikro. Istotne $\mathrm{w}$ tym kontekście są: poprawa $\mathrm{w}$ zakresie wykorzystywania posiadanych zasobów, umiejętności menedżerskie, przyjęte strategie biznesowe, elastyczne reagowanie na zmiany, zarządzanie innowacjami, responsywność, rozwinięte sieci współpracy (formalne i nieformalne), alianse i inne powiązania między firmami (np. w formie klastrów), interakcje między dostawcami, producentami i klientami ${ }^{18}$. Wyposażenie gospodarki czy danego sektora w zasoby o określonych właściwościach wynika zarówno z uwarunkowań naturalnych (położenia kraju, dostępu do surowców i innych zasobów naturalnych, czy czynników demograficznych), jak i uwarunkowań systemowych będących efektem funkcjonowania jednostek i grup społecznych w określonych kontekstach społeczno-kulturowych, gospodarczych i politycznych. W dobie gospodarki opartej na wiedzy i innowacjach kwalifikacje siły roboczej oraz kompetencje osób zarządzających przedsiębiorstwami, w tym przygotowanie do zarządzania innowacjami, uznawane są za jedne z podstawowych czynników determinujących konkurencyjność przedsiębiorstw. Odpowiednie wykształcenie i przygotowanie zasobów ludzkich wpływa też na pozostałe uwarunkowania konkurencyjności na poziomie mikro.

Powyższy przegląd pokazuje, że czynniki znajdujące się na poszczególnych poziomach przenikają się, oddziałując na cały kompleks relacji i interakcji kształtujących potencjał konkurencyjny gospodarek, sektorów i przedsiębiorstw. Dodatkowo, na wiele z nich wpływ mają szersze procesy międzynarodowe związane z postępującą globalizacją i rosnącą współzależnością państw i gospodarek. W rezultacie analizy konkurencyjności systemowej pozostają dużym wyzwaniem badawczym. Wciąż jednak podejście systemowe bądź strukturalne do konkurencyjności cieszy się sporym zainteresowaniem i poparciem czołowych ekonomistów i instytucji międzynarodowych. Tworzone obecnie globalne ran-

\footnotetext{
${ }_{17}^{17}$ J. Meyer-Stamer, Systemic Competitiveness, op. cit.

${ }^{18}$ Ibid.
} 
kingi konkurencyjności gospodarek bazują na ogólnym podejściu systemowym. Pojawiają się też nowe propozycje uporządkowania czynników systemowych kształtujących konkurencyjność współczesnych gospodarek. Jedną z nich jest propozycja M. Penedera, który odwołuje się do metafory „góry lodowej”, aby podkreślić, że na konkurencyjność wpływają i definiują ją zarówno czynniki łatwe do zaobserwowania, jak i czynniki mniej widoczne (ukryte pod taflą wody, a więc trudniejsze do obserwacji i mierzenia) ${ }^{19}$. Niewątpliwą zaletą podejścia systemowego jest jednak fakt, że przyjęte ramy analityczne mogą porządkować analizy konkurencyjności zarówno całej gospodarki, jej sektorów, jak i przedsiębiorstw. Co równie istotne, pozwalają również na przekrojową ocenę perspektyw rozwoju potencjału konkurencyjnego. W kolejnych częściach opracowania podejście systemowe wykorzystane zostanie do oceny potencjału konkurencyjnego polskiego sektora żywnościowego. Po analizie głównych czynników i zmian w otoczeniu międzynarodowym konkurencyjność polskiego sektora żywnościowego rozpatrywana będzie przez pryzmat głównych czynników ulokowanych na ww. czterech poziomach konkurencyjności systemowej.

\subsection{Globalizacja, integracja i dezintegracja? Dynamika zmian w otoczeniu międzynarodowym}

Otoczenie międzynarodowe $\mathrm{i}$ tendencje $\mathrm{w}$ gospodarce światowej mają fundamentalne znaczenie dla perspektyw rozwoju rolnictwa i całego sektora rolno-spożywczego ${ }^{20}$. Globalizacja i związana z nią liberalizacja wymiany handlowej produktami rolno-spożywczymi były w ostatnich dwóch dekadach niewątpliwie najważniejszymi procesami wpływającymi na światową gospodarkę żywnościową. W ich wyniku w niektórych państwach doszło do przyspieszonej koncentracji produkcji, handlu i kapitału, i w rezultacie do poprawy ekonomicznej efektywności sektorów żywnościowych. Państwa rozwinięte, które jeszcze w pierwszych dekadach powojennych pozostawały importerami netto żywności, są obecnie głównymi eksporterami produktów rolno-spożywczych na świecie. Natomiast kraje rozwijające się i najmniej rozwinięte odnotowują stały i pogłębiający się deficyt $\mathrm{w}$ handlu rolno-spożywczym ${ }^{21}$. Jest to efekt oddziaływania wielu czynników - wśród najważniejszych wymienić należy rosnące potrzeby

\footnotetext{
${ }^{19}$ M. Peneder, Competitiveness and industrial policy: from rationalities of failure towards the ability to evolve, „Cambridge Journal of Economics” 2017, t. 41, nr 3, s. 829-858.

${ }^{20}$ B. Nosecka, G. Dybowski, Globalne megatrendy a wzrost gospodarczy i rozwój oparty na wiedzy - sektor żywnościowy, seria „Monografie Programu Wieloletniego 2015-2019”, nr 17, IERiGŻ-PIB, Warszawa 2015.

${ }^{21}$ A. Jambor, S. Babu, Competitiveness of global agriculture: Policy lessons for food security, Springer International Publishing Switzerland, 2016, s. 47.
} 
żywnościowe ludności krajów rozwijających się, wynikające z wysokiej dynamiki przyrostu naturalnego oraz rosnącego poziomu dochodów, ograniczone zasoby i możliwości produkcyjne ich gospodarek żywnościowych, a także ograniczone możliwości konkurowania z bardziej dotowanymi sektorami rolnymi krajów rozwiniętych.

Światowy handel produktami rolno-spożywczymi od dłuższego czasu rozwija się dynamicznie. Obecnie handel rolno-spożywczy stanowi około $10 \%$ światowego handlu towarami. Międzynarodowy kryzys finansowy lat 2008-2009 doprowadził do spadku wielkości i wartości obrotów handlowych produktami rolno-spożywczymi w 2009 roku, jednak już w 2010 roku nastąpiło przezwyciężenie symptomów kryzysu i na tle pozostałych grup produktów odnotowano stosunkowo wysoką dynamikę wzrostu obrotów handlu rolno-spożywczego (wykres 1.1). W 2016 roku osiągnęły one rekordową wartość 3223 mld USD. Sam eksport rolno-spożywczy tylko w okresie od 2006 do 2016 roku wzrósł aż o 70\%. Średnio rocznie eksport produktów rolno-spożywczych rósł o ponad $5 \%{ }^{22}$. Według różnych szacunków globalny popyt na żywność ma nadal wzrastać $^{23}$. Prognozy ONZ wskazują, że do 2050 roku liczba ludności świata wzrośnie do 9,7 mld osób, co wymagać będzie zarówno zwiększenia poziomu produkcji w sektorze, jak i dalszej intensyfikacji wymiany handlowej produktami rolno-spożywczymi.

Handel rolno-spożywczy pozostaje wysoce skoncentrowany. Tylko na dwóch graczy - Unię Europejską i Stany Zjednoczone - przypada niemal połowa wartości globalnego handlu produktami rolno-spożywczymi (łącznie dla UE i USA 48,1\% wartości eksportu i 46,6\% wartości importu, z uwzględnieniem handlu wewnątrzunijnego ${ }^{24}$. Unia Europejska i USA zajmują również kluczową pozycję w globalnych łańcuchach wartości (GVC) w sektorze rolno-spożywczym, co częściowo wynika z dominacji amerykańskich i europejskich korporacji transnarodowych $\mathrm{w}$ przemyśle spożywczym oraz intensywnej wymiany $\mathrm{w}$ ramach sieci spółek zależnych. Kolejnymi głównymi eksporterami produktów rolno-

\footnotetext{
${ }^{22}$ World Trade Statistical Review, World Trade Organization 2017, https://www.wto.org/ english/res_e/statis_e/wts2017_e/wts2017_e.pdf.

${ }^{23}$ D. Tilman i in., Global food demand $\overline{\text { and }}$ the sustainable intensification of agriculture, Proceedings of the National Academy of Sciences, 2011, nr 108(50), s. 20260-20264; N. Alexandratos, J. Bruinsma, World agriculture towards 2030/2050: the 2012 revision, Rome FAO ESA Working paper, 2012, nr 12-03.

${ }^{24}$ World Trade Statistical..., op. cit., s. 112. Udział UE-28 w światowym eksporcie rolno-spożywczym, z uwzględnieniem eksportu wewnątrzunijnego, wyniósł w 2016 roku 37,7\%, bez eksportu wewnątrzunijnego 10,1\%. W tym samym roku USA miały 10,4\% udziału w światowym eksporcie rolno-spożywczym. Odpowiednie wartości dla importu wyniosły 36,8 i 10,2\% dla UE-28 oraz $9,8 \%$ dla USA.
} 
-spożywczych są: Brazylia (4,9\% udziału w eksporcie światowym w 2016 roku), Chiny (4,8\%), Kanada (4,0\%), Indonezja (2,4\%), Argentyna (2,3\%), Tajlandia $(2,3 \%)$, Australia $(2,1 \%)$ i Indie $(2,1 \%)^{25}$.

Wykres 1.1. Światowy handel towarami w podziale na główne grupy produktów w latach 2006-2016 (indeks $2006=100$ )

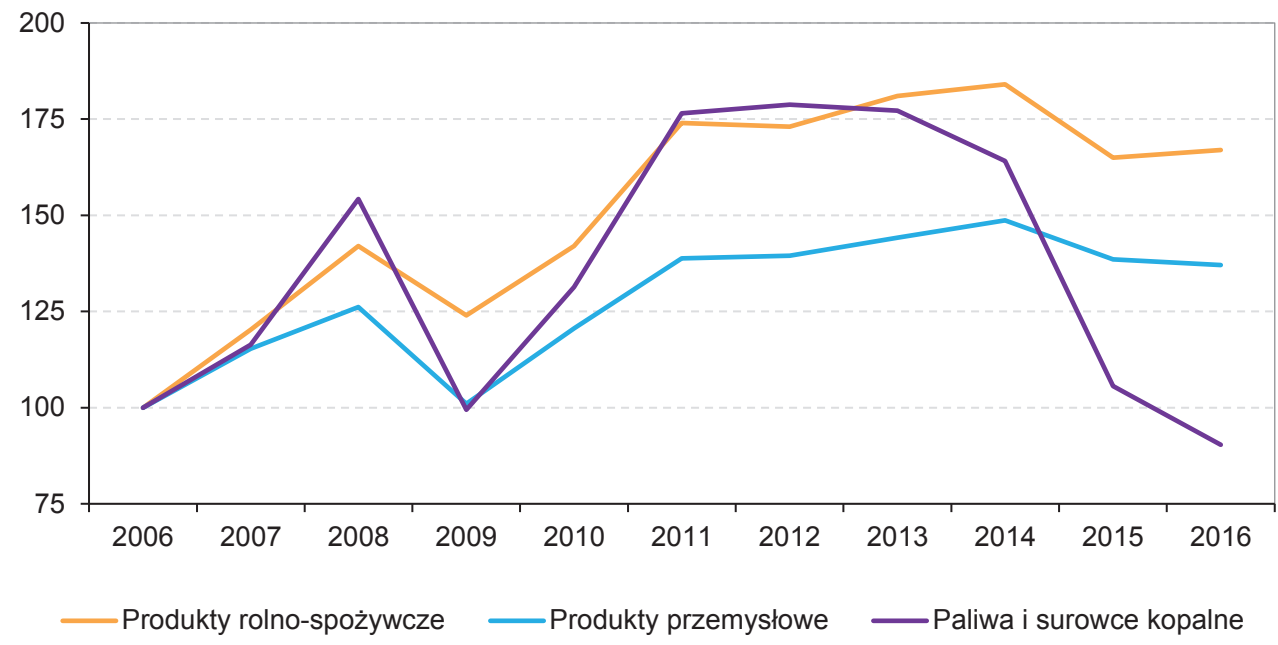

Źródto: opracowanie na podstawie WTO Trade Review Statistics 2017.

Ramy dla wielostronnego handlu rolno-spożywczego określa Porozumienie w sprawie Rolnictwa Rundy Urugwajskiej WTO, które przyjęte zostało w 1994 roku. Pomimo włączenia rolnictwa do dyscypliny WTO skala zakłóceń w handlu rolno-spożywczym wciąż jest bardzo wysoka - ich źródłem są zarówno wysokie stawki celne, subsydia rolnicze, jak i wzrastająca koncentracja rynkowa. Wyraźna dominacja państw najbogatszych w handlu produktami rolno-spożywczymi i szerzej w handlu międzynarodowym, jest jednym z głównych źródeł narastającej fali krytyki globalizacji gospodarczej. Choć globalizacja pozwoliła na wyjście wielu milionów ludzi z biedy, to równocześnie zwiększyła nierówności i podziały społeczne, przebiegające na różnych i nachodzących na siebie płaszczyznach - między kapitałem i pracą, regionami i przemysłami posiadającymi przewagi komparatywne oraz tymi, które są ich pozbawione, korporacjami transnarodowymi i lokalnymi producentami, pracownikami wykwalifikowanymi i niewykwalifikowanymi, pracownikami mobilnymi,

${ }^{25}$ Ibid. 
w tym imigrantami i miejscową ludnością, między elitami i zwykłymi ludźmi ${ }^{26}$. Podziały i napięcia te szczególnie dotkliwie odczuwane są w okresach kryzysów i spowolnień gospodarczych. W czasie ostatniego globalnego kryzysu finansowego i wysokiej fluktuacji cen artykułów żywnościowych przez wiele krajów przetoczyła się fala protestów społecznych, które przyczyniły się do destabilizacji i wzmocnienia sił politycznych opowiadających się za odgradzaniem się od świata i protekcjonizmem gospodarczym.

Obserwowana obecnie i narastająca w skali globalnej fala nowych ruchów nacjonalistycznych niesie wiele zagrożeń dla międzynarodowego ładu gospodarczego i politycznego ${ }^{27}$. Trudności w pogodzeniu interesów narodowych i ustaleniu zasad bardziej sprawiedliwej wymiany handlowej między państwami członkowskimi WTO doprowadziły de facto do fiaska rundy rozwojowej z Ad-Dauhy zapoczątkowanej w 2001 roku $^{28}$. Na konferencji ministerialnej WTO w Nairobi w grudniu 2015 roku podjęta została decyzja o odejściu od zasady „nic nie jest uzgodnione, dopóki wszystko nie jest uzgodnione” (single undertaking). Przyjęto, że celem nie będzie dążenie do porozumienia, które obejmie wszystkie państwa członkowskie. W zamian zadeklarowano dążenie do zawierania wielu innych mniejszych porozumień liberalizujących handel rolny między członkami WTO. Przejście od systemu wielostronnego do systemu plurilateralnego $^{29} \mathrm{w}$ istocie oznacza, że wynegocjowanie istotnego porozumienia WTO w sprawie rolnictwa nie będzie możliwe w najbliższej przyszłości ${ }^{30}$. Zawierane regionalne i megaregionalne porozumienia handlowe nie zawierają zobowiązań odnoszących się do krajowych systemów wsparcia dla rolnictwa. W tym momencie nie tylko kraje rozwinięte, ale również w coraz większym stopniu gospodarki wschodzące realizują rozbudowane programy subsydiowania producentów rolnych. System plurilateralny może więc prowadzić do nowych warunków wymiany handlowej w sektorze rolno-spożywczym, w tym także do ograniczeń w dostępie do niektórych rynków.

\footnotetext{
${ }^{26}$ D. Rodrik, Populism and the Economics of Globalization, „National Bureau of Economic Research" 2017, nr 23559.

${ }^{27}$ G.W. Kołodko, A.K. Koźmiński, Nowy pragmatyzm kontra nowy nacjonalizm, Prószyński i S-ka, Warszawa 2017.

${ }^{28}$ A. Martin, B. Mercurio, Doha dead and buried in Nairobi: lessons for the WTO, ,Journal of International Trade Law and Policy" 2017, t. 16, nr 1, s. 49-66.

${ }^{29}$ Porozumienia plurilateralne są dopuszczalną formą liberalizacji handlu międzynarodowego między członkami WTO. Obejmują mniejsze grupy państw, które łączą wspólne interesy i wspólne podejście do kwestii handlowych. Państwa decydują się na wzajemną liberalizację obrotów handlowych przede wszystkim w tych sektorach, które nie są dla nich wrażliwe.

30 J. Scott, The future of agricultural trade governance in the World Trade Organization, „International Affairs" 2017, t. 93, nr 5, s. 1167-1184.
} 
Nowe nacjonalizmy i niechęć do integracji gospodarczej widoczne są również na poziomie europejskim. Kryzys strefy euro, problem ogromnego i rosnącego zadłużenia publicznego niektórych państw członkowskich UE, kryzys imigracyjny i uchodźczy, wzrost poparcia dla radykalnych ruchów narodowych sprzyjały w ostatnich latach procesom dezintegracji w Europie. Jednym z ostatnich i najbardziej brzemiennych w skutkach przejawów malejącego poparcia dla idei integracji europejskiej jest decyzja Wielkiej Brytanii o wystąpieniu z UE. Wielka Brytania jest jednym z głównych importerów netto żywności w ramach UE oraz jednym z głównych płatników netto do budżetu UE, $w$ tym do budżetu Wspólnej Polityki Rolnej (WPR). Brexit może więc w istotnym stopniu wpłynąć na pozycję konkurencyjną unijnych, w tym polskich producentów żywności. Jednym z poważnie rozważanych scenariuszy jest organizacja handlu między Wielką Brytanią a UE na ogólnych zasadach WTO, która ograniczy dostęp do rynku brytyjskiego producentom z krajów UE. Prawdopodobne jest również ograniczenie wydatków na WPR, w tym wydatków na płatności bezpośrednie, które obecnie są ważnym źródłem dochodów rolniczych w UE. Utrzymujące się różnice zdań między państwami członkowskimi UE co do przyszłości integracji europejskiej wskazują, że dalsze pogłębianie integracji en bloc jest mało prawdopodobne. Pod koniec września 2017 roku prezydent Francji E. Macron przedstawił projekt rekonstrukcji UE - wskazał w nim na możliwość różnicowania tempa integracji poszczególnych państw, tj. ściślejszego integrowania się państw, które łączą wspólne ambicje ${ }^{31}$. Choć w zapowiedziach czołowych polityków europejskich nie ma sygnałów wskazujących na chęć demontażu wspólnej polityki w dziedzinie rolnictwa, pogłębianie integracji $\mathrm{w}$ innych obszarach oraz podejmowanie nowych inicjatyw integracyjnych w ramach mniejszych grup, może doprowadzić do nowej konfiguracji sił ekonomicznych, społecznych i politycznych oddziałujących na pozycję i potencjał konkurencyjny poszczególnych państw członkowskich Unii Europejskiej.

Procesy dezintegracji w UE pozostają bardzo niekorzystnym zjawiskiem również w kontekście nowych uwarunkowań związanych z postępem rewolucji technologicznej i rozwojem nowych technologii informacyjno-komunikacyjnych. Pomimo społecznych protestów i zmian politycznych w wielu państwach świata, globalizacja nie tylko nadal postępuje, ale dodatkowo przyspiesza. Świat wkracza w nową erę globalizacji cyfrowej, która może w sposób fundamentalny zmienić

${ }^{31}$ E. Macron, Initiative for Europe. A sovereign, united, democratic Europe, 26 September 2017, http://www.elysee.fr/assets/Initiative-for-Europe-a-sovereign-united-democratic-EuropeEmmanuel-Macron.pdf. 
funkcjonowanie poszczególnych sektorów, przemysłów czy branż ${ }^{32}$ (wykres 1.2). Wskazuje się, że dane cyfrowe staną się nowym kluczowym zasobem ekonomicznym o potencjalnie dużym znaczeniu dla wzrostu produktywności i wzrostu gospodarczego na świecie ${ }^{33}$.

Wykres 1.2. Nowa era globalizacji cyfrowej - przepływ danych i komunikacji w skali globalnej w latach 2005-2014

(wykorzystanie łączy szerokopasmowych w tysiącach gigabitów na sekundę)

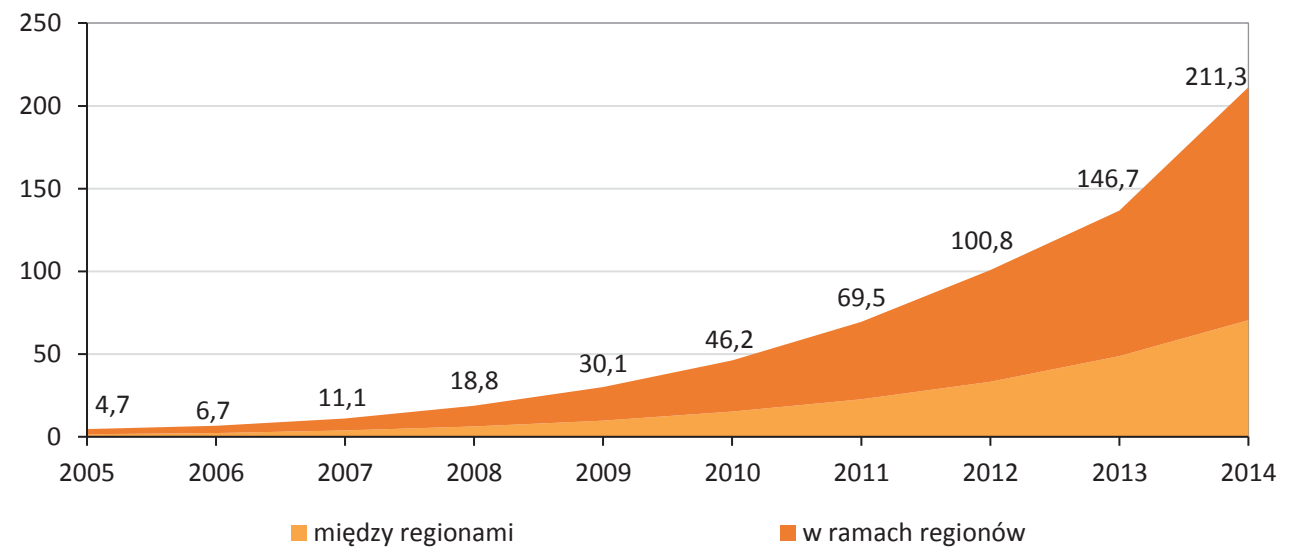

Źródto: opracowanie na podstawie J. Manyika i in., Digital globalization: The new era of global flows, McKinsey Global Institute, 2016.

Obecny moment cyfrowego przełomu (digital disruption) określany jest coraz częściej mianem czwartej rewolucji przemysłowej (Industry 4.0). Jej podstawą są: zaawansowana analityka bazująca na wielkich zbiorach danych (Big Data) ${ }^{34}$, Internet Rzeczy (Internet of Things) ${ }^{35}$, wytwarzanie przyrostowe (additive

\footnotetext{
${ }^{32} \mathrm{~K}$. Cukier, V. Mayer-Schoenberger, The rise of big data: How it's changing the way we think about the world, „Foreign Affairs” 2013, vol. 92(3), s. 28; E. Brynjolfsson, A. McAfee, The second machine age: Work, progress, and prosperity in a time of brilliant technologies, WW Norton \& Company, 2014.

${ }^{33}$ J. Manyika i in., Digital globalization: The new era of global flows, McKinsey Global Institute, 2016.

${ }^{34}$ Termin ten używany jest do określenia olbrzymich i zróżnicowanych zbiorów danych cyfrowych (ustrukturyzowanych i nieustrukturyzowanych), które generowane są nieustannie z dużą prędkością i dla których tradycyjne relacyjne bazy danych i tradycyjne techniki przetwarzania i analizy nie są wystarczające. Wykorzystanie wielkich zbiorów danych do odkrywania nowych zależności i zdobywania wiedzy wymaga zastosowania nierelacyjnych baz danych i zaawansowanych narzędzi analitycznych, w tym algorytmów maszynowego uczenia się.

${ }^{35}$ Internet Rzeczy jest jednym z kluczowych źródeł tworzenia wielkich zbiorów danych. Oznacza system połączonych inteligentnych urządzeń, czujników i sensorów komunikujących się ze sobą za pomocą Internetu.
} 
manufacturing) $)^{36}$, automatyzacja i sztuczna inteligencja ${ }^{37}$. Niespotykany dotąd dynamizm zmian związanych $\mathrm{z}$ rewolucją technologiczną i cyfryzacją zmienia wagę czynników decydujących o przewagach konkurencyjnych. W przypadku gospodarki żywnościowej można mówić o dwóch najważniejszych trendach związanych z rozwojem nowoczesnych technologii - rolnictwie opartym na danych, wykorzystującym m.in. drony i Internet Rzeczy do poprawy w zakresie wykorzystania czynników produkcji (bardziej zaawansowanej wersji rolnictwa precyzyjnego), oraz o cyfryzacji przemysłu spożywczego, polegającej m.in. na wykorzystaniu analityki wielkich zbiorów danych do optymalizacji procesów zarządzania produkcją i łańcuchem dostaw, rozwoju nowych produktów czy poprawy działań w obszarze marketingu i komunikacji z klientem. Zmiany te prowadzą do coraz ostrzejszej konkurencji, nie tylko w ramach poszczególnych sektorów i przemysłów, ale również pomiędzy nimi. Dochodzi do zacierania się granic między branżami - już obecnie tradycyjne przedsiębiorstwa stawiają czoła firmom, których nigdy wcześniej nie postrzegały jako konkurencji ${ }^{38}$. Można zakładać, że również łańcuch żywnościowy będzie podlegał istotnym przeobrażeniem w najbliższych latach w związku z postępującym procesem globalizacji cyfrowej ${ }^{39}$. Intensyfikacja przepływów komunikacyjnych prowadzi do skrócenia dystansu między poszczególnymi ogniwami łańcucha. W sposób wyraźny stawia też konsumenta i jego preferencje w centrum uwagi. Obecnie trendy i nowości na rynku żywnościowym rozprzestrzeniają się bardzo szybko. Konsumenci oczekują już nie tylko żywności o bardzo wysokiej jakości, określonych walorach prozdrowotnych oraz dostarczonej w możliwie najwygodniejszy sposób. Najbardziej zaangażowani konsumenci chcą również mieć wpływ na projektowanie składu wybranych produktów żywnościowych, a także ich opakowań.

Nowe uwarunkowania wymuszają przyjmowanie innowacyjnych modeli biznesowych i nowych metod działania mających na celu utrzymanie pozycji na rynku i wzrost potencjału konkurencyjnego. W warunkach wykładniczego postępu technologicznego konkurencyjność może rozwijać się nie liniowo, a skokowo.

\footnotetext{
${ }^{36}$ Wytwarzanie przyrostowe, znane bardziej pod pojęciem druku 3D, oznacza proces tworzenia obiektów fizycznych przy pomocy grafiki 3D i oprogramowania komputerowego wspierającego proces projektowania. Możliwe zastosowania dotyczą również żywności, gdy w drukarce zamiast tuszu umieszczone zostaną takie składniki, jak cukier, skrobia czy białka.

${ }^{37}$ M. Goenaga i in., Ops 4.0: Fueling the next 20 percent productivity rise with digital analytics, April 2017, https:/www.mckinsey.com/business-functions/operations/our-insights/ops4-0-fueling-the-next-20-percent-productivity-rise-with-digital-analytics.

${ }^{38}$ V. Atluri, M. Dietz, N. Henke, Competing in a world of sectors without borders, McKinsey Quarterly, July 2017.

${ }^{39}$ Przykładem takiej zmiany może być zakup na rynku amerykańskim sieci sklepów spożywczych Whole Foods w 2017 roku przez firmę Amazon, działającą od lat z powodzeniem w branży internetowej.
} 
T. Ndlovu i A. Mariussen wskazują, że ważnym źródłem przewagi konkurencyjnej będzie umiejętność pokonania konkurencji albo poprzez pominięcie niektórych etapów na ścieżce rozwoju, którą musieli przejść liderzy, albo poprzez przyjęcie nowych koncepcji rozwoju i dokonanie wyraźnego skoku do przodu (competitive leapfrogging) ${ }^{40}$. Szybka reakcja na potrzeby rynku nie jest już wystarczającym źródłem przewagi - w dobie nieograniczonego dostępu do informacji strategie konkurencyjne liderów są powielane i szybko tracą na wartości. Problemem może być jednak obecna dominacja na rynku kilku gigantów technologii cyfrowych, którzy kontrolują zdecydowaną większość globalnych przepływów danych i informacji.

Wspólnota międzynarodowa nie zdołała dotąd włączyć kwestii cyfryzacji do międzynarodowego reżimu regulacyjnego, choć sam temat digitalizacji i handlu elektronicznego jest przedmiotem dyskusji na różnych forach, m.in. na forum WTO. Można mieć obawy, czy w sytuacji obecnego kryzysu instytucji międzynarodowych taki reżim zostanie wypracowany w najbliższej przyszłości. Działania regulacyjne dotyczące przepływu danych cyfrowych i ich wykorzystywania podejmuje UE, dotyczą one jednolitego rynku cyfrowego. Biorąc pod uwagę tendencje dezintegracyjne w UE, a przede wszystkim ponadregionalny wymiar rewolucji cyfrowej, nie jest jasne, do jakiego stopnia inicjatywa ta poprawi pozycję i potencjał konkurencyjny przedsiębiorców w Europie. Nie jest też jasne, w jaki sposób obecna fala globalizacji cyfrowej wpłynie na podziały i nierówności, które wcześniej narosły w wyniku globalizacji opartej na przepływie towarów, usług i kapitału. Tempo przemian narzucanych przez procesy globalizacji pozostanie jednak zawsze szybsze niż działania regulacyjne. Kluczowa zatem dla gospodarek, sektorów i przedsiębiorstw będzie odpowiednio wczesna adaptacja do nowych wyzwań i warunków konkurencji.

\subsection{Krajowe uwarunkowania konkurencyjności sektora żywnościowego}

\subsubsection{Wartości i czynniki społeczno-kulturowe}

W ocenach potencjału konkurencyjnego dokonywanych z perspektywy konkurencyjności systemowej uwzględniane są czynniki społeczno-kulturowe oraz uwarunkowania związane $\mathrm{z}$ dominującymi $\mathrm{w}$ społeczeństwie normami i wartościami. Jak wskazuje odwołanie do metafory góry lodowej, są to często

\footnotetext{
${ }^{40}$ T. Ndlovu, A. Mariussen, From Competitive Agility to Competitive Leapfrogging: Responding to the Fast Pace of Change, [w:] L.M. Carmo Farinha, J.J.M. Ferreira, H. Lawton Smith i S. Bagchi-Sen (red.), Handbook of Research on Global Competitive Advantage through Innovation and Entrepreneurship, Information Science Reference, IGI Global, 2015.
} 
czynniki mniej oczywiste i widoczne, jednak o fundamentalnym znaczeniu dla perspektyw rozwoju konkurencyjności. Warto podkreślić, że czynniki te, jako znajdujące się u samych podstaw konkurencyjności, podlegają najwolniejszym zmianom $^{41}$. Znajdują się też poza zasięgiem bezpośredniego oddziaływania polityki czy działań interwencyjnych państwa, choć zdaniem niektórych badaczy można na nie wpływać poprzez wytrwałą reformę instytucjonalną w długiej perspektywie czasu ${ }^{42}$.

Można zakładać, że na obecną konkurencyjność polskiego sektora żywnościowego wpływ miało wiele reguł, wzorców postępowania i postaw wynikających z zakorzenionych w polskim społeczeństwie norm i wartości. W kontekście przedstawionych wyżej trendów w gospodarce światowej szczególną uwagę warto poświęcić ogólnej gotowości do komunikacji i współpracy. Umiejętność współpracy i rozwijania sprawnej sieci kontaktów społecznych na różnych poziomach od dawna uznawana jest za jeden z kluczowych czynników decydujących o przewagach konkurencyjnych ${ }^{43}$. W dobie społeczeństwa sieciowego przepływy informacji, komunikacja i współpraca nabierają dodatkowego znaczenia - w coraz większym stopniu przepływy te organizują i warunkują zarówno konsumpcję, jak i produkcję ${ }^{44}$.

Gotowość do komunikacji i współpracy jest jednym z podstawowych składników kapitału społecznego. Na jej poziom wpływają zarówno jakość i gęstość istniejących więzi społecznych, jak i zaufanie. Jak wskazuje P. Sztompka, wysoki poziom kapitału społecznego sprzyja nie tylko kooperacji, ale również innowacyjności (jako efekt dobrej komunikacji i dostępności do informacji), efektywności działania (jako efekt pozytywnej rywalizacji) i konkurencyjności (m.in. poprzez obniżenie kosztów transakcyjnych i zewnętrznych, dodatkowych obciążeń działalności w rezultacie odformalizowania relacji) ${ }^{45}$. Sektor żywnościowy jest szczególnym sektorem gospodarki ze względu na bardzo rozbudowany kompleks relacji przebiegających pionowo i poziomo pomiędzy różnymi podmiotami zaangażowanymi $\mathrm{w}$ wiele faz produkcji i dystrybucji, od momentu wytworzenia surowców do dostarczenia gotowej żywności konsumentom. Rola kapitału społecznego, współpracy i zaufania w takim kompleksie jest więc trudna

${ }^{41}$ D. Messner, The Network Society..., op. cit.

${ }^{42} \mathrm{M}$. Peneder, Competitiveness and industrial policy..., op. cit.

${ }^{43} \mathrm{Na}$ ten wymiar konkurencyjności szczególną uwagę zwraca Michael Porter. M.E. Porter, Clusters and the new economics of competition, Boston: Harvard Business Review, 1998, t. 76 , nr 6 .

${ }^{44} \mathrm{M}$. Castells, The rise of the network society: The information age: Economy, society, and culture, t. 1, Wiley \& Blackwell, 2011.

${ }^{45}$ P. Sztompka, Kapital społeczny. Teoria przestrzeni międzyludzkiej, Wydawnictwo Znak, Kraków 2016, s. 309, 313. 
do przecenienia. Istotna dla poprawy efektywności działania i konkurencyjności jest zarówno współpraca i integracja pozioma (m.in. między gospodarstwami rolnymi wytwarzającymi ten sam produkt lub grupę produktów, szczególnie w regionach o rozdrobnionej strukturze agrarnej), jak i integracja pionowa polegająca na współpracy jednostek z różnych ogniw łańcucha dostaw lub na łączeniu wszystkich ogniw procesu produkcyjnego, od pola do stołu, w jednym przedsiębiorstwie. Współpraca i zaufanie są podstawowymi wartościami również z punktu widzenia zapewniania bezpieczeństwa żywności i wysokiej jakości produktów rolno-spożywczych.

Badania przeprowadzane przez międzynarodowe instytucje badawcze wskazują, że Polska należy do krajów o stosunkowo niskim poziomie kapitału społecznego i zaufania. W rankingu Instytutu Legatum z 2016 roku, oceniającym poziom dobrobytu na podstawie różnych wskaźników, Polska znalazła się dopiero na 85. pozycji na 149 krajów ocenianych pod względem wyposażenia w kapitał społeczny ${ }^{46}$. Choć Polacy wierzą w sens współpracy z innymi ludźmi, równocześnie pozostają sceptyczni w ocenie skuteczności wspólnego działania przy rozwiązywaniu problemów swojego środowiska. Większość Polaków nie jest też skłonna angażować się wspólnie z innymi w działalność gospodarczą i społeczną ${ }^{47}$. Potencjał kapitału społecznego wydaje się jeszcze niższy w przypadku mieszkańców wsi żyjących w rodzinach utrzymujących się z rolnictwa. Rolników i członków rodzin rolniczych cechuje ponadprzeciętna nieufność wobec ludzi - przekonanie, że w stosunkach z innymi trzeba być bardzo ostrożnym w 2013 roku wyrażało aż 88\% respondentów z tej grupy ${ }^{48}$. Osoby z rodzin rolniczych cechował również większy konserwatyzm. Na pytania o najważniejsze wartości w ich życiu zdecydowana większość wskazywała na dwie wartości szczęście rodzinne i dobre zdrowie. Wartości o bardziej wspólnotowym i gospodarczym charakterze otrzymywały znacznie mniejszą ilość wskazań (pomyślność ojczyzny, dobrobyt i bogactwo, wykształcenie, sukces, praca zawodowa) ${ }^{49}$.

Stosunkowo niski poziom kapitału społecznego w rolnictwie potwierdzają badania poświęcone zrzeszaniu się rolników oraz funkcjonowaniu grup producentów rolnych w Polsce. Polscy producenci rolni niechętnie i w ograniczonym stopniu podejmują wspólne działania na rynku ${ }^{50}$. Choć tempo integracji poziomej

\footnotetext{
${ }^{46}$ Legatum Prosperity Index 2016, http://www.prosperity.com.

${ }^{47}$ Gotowość do wspótpracy, Komunikat z badań CBOS, nr 22, Warszawa, luty 2016.

${ }^{48}$ Wieś polska - charakterystyka ludności rolniczej, Komunikat z badań CBOS, BS/138/2013, Warszawa, październik 2013.

${ }^{49}$ Ibid.

${ }^{50} \mathrm{P}$. Prus, Czynniki hamujące chęć organizowania się rolników w grupy producentów rolnych, [w:] S. Zawisza (red.), Perspektywy rozwoju grup producentów rolnych - szanse i zagrożenia, Wydawnictwa Uczelniane Uniwersytetu Technologiczno-Przyrodniczego, Bydgoszcz 2010.
} 
wzrosło w stosunku do pierwszych lat członkostwa w UE, nadal odsetek rolników realizujących wspólne działania na płaszczyźnie gospodarczej jest znacznie niższy niż w krajach tzw. starej UE ${ }^{51}$. Dodatkowo badania wskazują, że niektóre z zakładanych grup producentów rolnych kierują się jedynie chęcią wykorzystania ustawowego wsparcia, nie podejmując przy tym działań o charakterze rozwojowym $^{52}$. Problemem jest też niewystarczająca integracja pionowa w łańcuchu dostaw, choć należy zaznaczyć, że skala problemu jest zróżnicowana na poziomie poszczególnych sektorów. Konsolidację produkcji i handlu wspierają korporacje transnarodowe, które odgrywają coraz większą rolę w strukturze polskiego przemysłu spożywczego ${ }^{53}$. Barierą jednak pozostaje wciąż stosunkowo niski poziom zaufania konsumentów do przemysłu spożywczego w Polsce. Choć zaufanie to stopniowo wzrasta, wciąż zaledwie połowa Polaków ufa przedsiębiorstwom tego sektora ${ }^{54}$.

Niewielka ilość oddolnych inicjatyw współpracy, zarówno między producentami rolnymi, jak i między producentami rolnymi, podmiotami przetwórstwa spożywczego i sieciami handlowymi, ogranicza konkurencyjność polskiego sektora żywnościowego. Jest to poważna bariera rozwojowa dla polskiego rolnictwa i przemysłu spożywczego, ponieważ potrzeby w zakresie kooperacji i wymiany informacji już obecnie są ogromne, a w najbliższym okresie istotnie jeszcze wzrosną. Wprowadzenie i stosowanie na szeroką skalę nowych technologii rolnictwa Big Data wymaga współpracy między producentami, dzielenia się wiedzą i doświadczeniami, wymiany informacji i danych, tworzenia otwartych wspólnot uczących się. Równolegle kluczowa dla dyfuzji innowacji w sektorze żywnościowym będzie otwartość na współpracę z podmiotami spoza sektora - centrami naukowo-badawczymi, firmami wysokich technologii, start-upami, użytkownikami sieci, mediów społecznościowych i innych platform innowacyjnych nastawionych na wymianę informacji, crowdsourcing idei i produktów. Dzięki postępowi technologicznemu, nowym narzędziom współpracy oraz dzieleniu się wiedzą i zasobami możliwe jest obecnie osiąganie przewag i korzyści, które wcześniej było stosunkowo trudno osiągać. Obserwowane obecnie zjawiska, takie jak eko-

\footnotetext{
${ }^{51}$ P. Prus i in., Działalność ośrodków doradztwa rolniczego w procesie integracji poziomej $w$ rolnictwie $w$ opinii członków grup producentów rolnych, „Roczniki Naukowe Stowarzyszenia Ekonomistów Rolnictwa i Agrobiznesu" 2014, t. XVI, z. 3, s. 242-246; A. Nowak, R. Gąsior, Integracja pozioma producentów rolnych - możliwości $i$ bariery, „Annales Universitatis Mariae Curie-Skłodowska", sectio H - Oeconomia 2017, t. 51, nr 1.

${ }^{52}$ M. Domagalska-Grędys, Kontekst innowacji w grupach producentów rolnych, „Wieś i Rolnictwo" 2016, nr 1(170).

${ }^{53} \mathrm{P}$. Chechelski, Korporacje transnarodowe $w$ przemyśle spożywczym w Polsce, Prezentacja z seminarium IERiGŻ-PIB, Warszawa, 6.10.2017.

${ }^{54}$ Edelman Trust Barometer 2016, https://www.edelman.com/post/trust-food-beverage-five-steprecipe-success/.
} 
nomia współpracy i ekonomia współdzielenia (collaborative economy, sharing economy) nie tylko zmieniają otoczenie i warunki konkurencji, ale redefiniują również samą konkurencyjność oraz czynniki ją kształtujące. Można przypuszczać, że konkurencyjność w coraz większym stopniu zależeć będzie od czynników społeczno-kulturowych, w tym od poziomu wyposażenia danego kraju, gospodarki, czy sektora w kapitał społeczny i zaufanie. W tym kontekście można mieć obawy, czy polski sektor żywnościowy będzie w stanie wzmacniać swój potencjał konkurencyjny w najbliższej przyszłości.

\subsubsection{Uwarunkowania makroekonomiczne i instytucjonalne rozwoju konkurencyjności sektora żywnościowego w Polsce}

Sytuacja makroekonomiczna, w tym makroekonomiczna stabilność oraz stabilne, efektywne instytucje mają fundamentalne znaczenie dla wzmacniania i poprawy konkurencyjności gospodarki, jej sektorów i przedsiębiorstw. Polska od niemal trzech dekad jest krajem, w którym obowiązuje ustrój demokracji parlamentarnej oraz zasady gospodarki rynkowej. Dynamizm rozwojowy całej gospodarki i tempo jej przekształceń już w latach 90. ubiegłego wieku zaczęły tworzyć dobry klimat makroekonomiczny dla poprawy konkurencyjności sektora przetwórstwa spożywczego ${ }^{55}$. Postępująca integracja polskiej gospodarki z gospodarką światową, w tym z gospodarkami krajów UE, zapewniła dodatkowe bodźce rozwojowe, które pozwoliły na dalsze wzmacnianie konkurencyjności polskich producentów żywności ${ }^{56}$. W rezultacie systemowych przekształceń, modernizacji i integracji gospodarczej Polska należy obecnie do grupy krajów UE z najwyższą dynamiką wzrostu gospodarczego. Średnie tempo wzrostu PKB między 2004 a 2016 rokiem wynosiło 3,9\% (o 2,7 pkt proc. więcej niż w przypadku UE-15). Od momentu przystąpienia do UE następuje stopniowe zmniejszanie dystansu, jaki dzieli gospodarkę Polski od bardziej zaawansowanych gospodarek europejskich. W okresie od 2004 do 2016 roku wartość PKB na mieszkańca w Polsce, według parytetu siły nabywczej, w relacji do średniej dla UE-28 wzrosła z 50 do 69\%, natomiast w relacji do średniej UE-15 z 44 do $64 \%{ }^{57}$.

Utrzymujący się wzrost gospodarczy w Polsce jest pochodną stabilności makroekonomicznej. Polska gospodarka jest obecnie jedną z najlepiej zrównoważonych pod względem makroekonomicznym gospodarek europejskich. W okre-

\footnotetext{
${ }^{55}$ R. Urban, Czynniki wzrostu konkurencyjności polskiego przemystu spożywczego, „Zagadnienia Ekonomiki Rolnej" 1999, nr 2-3, s. 20-30.

${ }^{56}$ I. Szczepaniak, Konkurencyjność polskiego przemystu spożywczego na rynku krajowym i międzynarodowym - wybrane elementy, ,Roczniki Naukowe Stowarzyszenia Ekonomistów Rolnictwa i Agrobiznesu" 2014, t. XVI, z. 4, s. 281-287.

${ }^{57}$ Baza danych Eurostatu: http://ec.europa.eu/eurostat/data/database.
} 
sie od 2004 do 2016 roku bezrobocie w Polsce spadło z 19\% ludności aktywnej zawodowo do $8,2 \%$. Założenia polityki pieniężnej od lat pozostają niezmienne. Od 2004 roku Rada Polityki Pieniężnej realizuje politykę celu inflacyjnego w wysokości 2,5\%, z odchyleniami do 1 pkt proc. w górę lub w dół. Przeciętny poziom inflacji w okresie od 2004 do 2016 roku wynosił 2,16\%. Relatywnie dobrze kształtowała się również relacja deficytu sektora finansów publicznych do PKB. Zwiększony deficyt w finansach publicznych w Polsce odnotowywano w momentach kryzysu i recesji gospodarczej na świecie (jak globalny kryzys finansowy i kryzys strefy euro), jednak już po 2013 roku deficyt systematycznie spadał (w 2014 roku wyniósł 3,6\% PKB, w 2015 roku - 2,6\%, a w 2016 roku 2,5\%). W 2016 roku dług publiczny w stosunku do PKB wynosił 54\%. Poprawiła się też $\mathrm{W}$ ostatnich latach relacja rachunku bieżącego bilansu płatniczego do $\mathrm{PKB}$, co w dużym stopniu było zasługą rosnącej wartości polskiego eksportu. Deficyt na rachunku obrotów bieżących zmniejszył się z poziomu $-5,5 \%$ PKB w 2004 roku do $-0,3 \%$ w 2016 roku $^{58}$.

Prognozy dla polskiej gospodarki na najbliższe lata są również korzystne. Międzynarodowy Fundusz Walutowy przewiduje, że PKB w Polsce w okresie od 2017 do 2022 roku będzie rósł średnio o 3\% rocznie. Obok stosunkowo wysokiej dynamiki wzrostu PKB prognozowane jest dalsze zmniejszanie bezrobocia $^{59}$. Suma czynników decydujących o równowagach wewnętrznych i zewnętrznych pozwala sądzić, że w najbliższym okresie Polska pozostanie krajem stabilnym pod względem makroekonomicznym (wykres 1.3). Ewentualne pogorszenie stabilności makroekonomicznej może nastąpić w wyniku stopniowego wzrostu inflacji oraz większej nierównowagi zewnętrznej powodowanej wyższą nierównowagą w handlu międzynarodowym ${ }^{60}$.

Obserwowana w ostatnim okresie dynamika zmian w zakresie produktywności pracy i kosztów pracy w polskiej gospodarce skłania do twierdzenia o możliwości pogorszenia się w niedługim horyzoncie czasowym konkurencyjności kosztowej polskiego eksportu. Choć produktywność pracy mierzona PKB na jedną przepracowaną godzinę wyraźnie wzrosła od czasu przystąpienia Polski do UE (o 35\% między 2004 a 2016 rokiem), wciąż jest dwukrotnie niższa niż w niektórych krajach UE-15 (w 2016 roku PKB na jedną przepracowaną godzinę wyniósł w Polsce nieco ponad 29 USD, w Niemczech niemal 60 USD, w Holandii 61 USD, w Danii 63 USD) ${ }^{61}$. Przewagę polskim przedsiębiorcom zapew-

\footnotetext{
${ }^{58}$ Baza danych GUS: https://stat.gov.pl/wskazniki-makroekonomiczne/.

${ }^{59}$ Baza danych Międzynarodowego Funduszu Walutowego: http://www.imf.org/en/data.

${ }^{60}$ J. Janecki, Pomiar i ocena stabilności makroekonomicznej w Polsce, „Acta Universitas Lodzensis. Folia Oeconomica" 2017, t. 2, nr 328.

${ }^{61}$ Baza danych OECD: https://data.oecd.org.
} 
niały dotąd bardzo niskie koszty pracy (średnio o dwie trzecie mniejsze niż przeciętnie w UE-15) oraz stosunkowo umiarkowane tempo ich wzrostu. Prognozowany wzrost popytu na pracę najprawdopodobniej będzie jednak przekładał się w najbliższym okresie na silniejszy wzrost jednostkowych kosztów pracy ${ }^{62}$. Prawdopodobne będzie więc pogłębianie się różnicy między kosztami i wydajnością pracy (w związku z niższą dynamiką wzrostu wydajności), co może negatywnie wpływać na konkurencyjność polskiego eksportu, w tym eksportu żywności.

Wykres 1.3. Zewnętrzna i wewnętrzna stabilność w Polsce w latach 2002-2020, mierzona na podstawie metody pięciokąta stabilizacji makroekonomicznej (PSM)

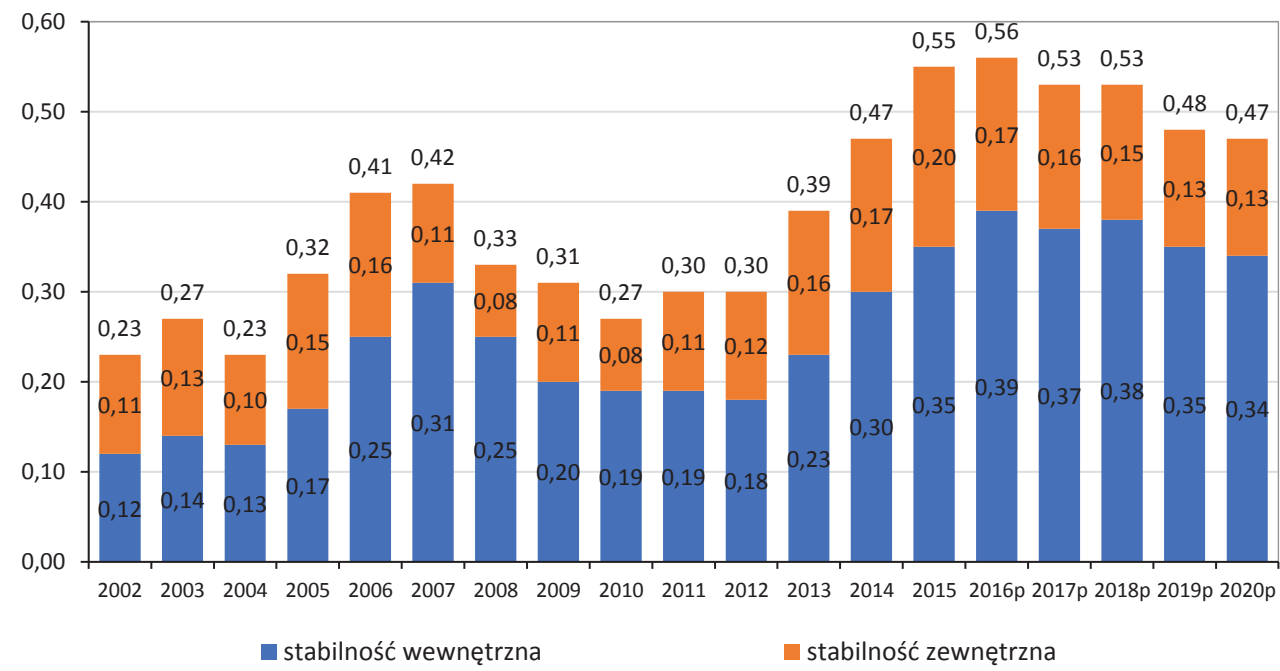

$\mathrm{p}$ - prognoza

Źródto: opracowanie na podstawie J. Janecki, Pomiar i ocena stabilności makroekonomicznej w Polsce, ,Acta Universitas Lodzensis. Folia Oeconomica” 2017, t. 2, nr 328, s. 130.

Obok uwarunkowań makroekonomicznych konkurencyjność polskiego sektora żywnościowego kształtują również szersze uwarunkowania instytucjonalne związane z jakością rządzenia w państwie i stabilnością instytucji. Choć pod względem jakości rządzenia i sprawności sektora publicznego nastąpiła w ciągu ostatnich dekad wyraźna poprawa, istnieją jeszcze obszary, w których stabilność i wzrost efektywności mogłyby przełożyć się na lepsze perspektywy wzrostu konkurencyjności polskiej gospodarki i jej sektorów. W szacunkach Banku Światowego, który mierzy jakość rządzenia za pomocą sześciu wymia-

\footnotetext{
${ }^{62}$ Dane z drugiego kwartału 2017 roku wskazują, że Polska należała do państw, w których nominalne godzinowe koszty pracy wzrosły najbardziej (wzrost o $8,3 \%$ rdr wobec 2,2\% w całej Unii), Eurostat, Newsrelease Euroindicators, 139/2017 - 15 September 2017.
} 
rów - demokratycznej kontroli, rządów prawa, jakości regulacji, stabilności politycznej i braku przemocy, efektywności państwa, kontroli korupcji - Polska wciąż uzyskuje stosunkowo niskie wyniki. Na skali od -2,5 do 2,5 średnie wartości dla poszczególnych wskaźników w okresie od 2004 do 2016 roku kształtowały się w Polsce na poziomie od 0,48 do 0,97 . W tym samym okresie średnie wartości dla Danii wynosiły od 1,6 do 2,4, dla Finlandii od 1,3 do 2,2, dla Holandii od 0,98 do 2,0, a dla Niemiec od 0,85 do 1,8. Ostatnie szacunki Banku Światowego dla Polski wskazują dodatkowo na spadek wskaźników dla wszystkich wskazanych wymiarów, z wyjątkiem kontroli korupcji ${ }^{63}$. Stabilność instytucjonalna i jakość instytucji w Polsce wypadła gorzej również w badaniu Światowego Forum Ekonomicznego ${ }^{64}$. Obserwowana w ostatnich latach stosunkowo wysoka zmienność otoczenia regulacyjnego i legislacyjnego zwiększa poziom niepewności w gospodarce, co może ograniczać plany inwestycyjne i rozwojowe polskich przedsiębiorstw ${ }^{65}$.

Prawo dotyczące konkurencji oraz regulacje odnoszące się bezpośrednio do sektora żywnościowego pozostają jednak stabilne. Rozwinięty system instytucji krajowych i wspólnotowych na poziomie UE gwarantuje skuteczne egzekwowanie zarówno przepisów prawa konkurencji, jak i prawa żywnościowego. Instytucje i regulacje prawne zapewniają również pewność obrotu gospodarczego w transakcjach krajowych i międzynarodowych. Polska należy obecnie do krajów, których stopień integracji z jednolitym rynkiem unijnym w ramach wewnątrzwspólnotowej wymiany towarowej jest jednym z najwyższych w $\mathrm{UE}^{66}$. Choć nadal pojawiają się problemy i opóźnienia w zakresie implementacji niektórych regulacji unijnych do krajowego porządku prawnego, w mniejszym stopniu dotyczą one sektora rolno-spożywczego ${ }^{67}$. Sprawny proces wdrażania i egzekwowania prawa w tym obszarze jest istotny, ponieważ przedsiębiorstwa przemysłu spożywczego podkreślają, że harmonizacja prawa żywnościowego na poziomie UE (w ramach Ogólnego Prawa Żywnościowego UE oraz regulacji odnoszących się do bezpieczeństwa i jakości żywności) jest jednym z głównych elementów

\footnotetext{
${ }^{63}$ Baza danych Banku Światowego: http://databank.worldbank.org/.

${ }^{64}$ World Economic Forum, The Global Competitiveness Report 2017-2018, http://reports. weforum.org/global-competitiveness-index-2017-2018/.

${ }^{65}$ Narodowy Bank Polski, Szybki Monitoring NBP. Analiza sytuacji sektora przedsiębiorstw, nr 04/17, Warszawa, październik 2017.

${ }^{66}$ Single Market Scoreboard, Performance by Member State - Poland, http://ec.europa.eu/internal market/scoreboard/performance_by_member_state/poland/index_en.htm\#maincontentSec 2 .

${ }^{67}$ Commission staff working document accompanying the document "Monitoring the application of European Union law 2016 Annual Report" (Part I: Policy areas, Part II: Member States), Brussels, 6.7.2017.
} 
wzmacniających ich konkurencyjność na rynku europejskim i globalnym ${ }^{68}$. Obecne regulacje krajowe i unijne budują reputację oraz markę polskiej żywności jako żywności wysokiej jakości. W związku z rosnącymi wymogami konsumentów, w tym także rosnącym popytem na żywność wysokiej jakości ze strony klasy średniej w gospodarkach wschodzących, właściwe wdrażanie i stosowanie wspólnotowych i krajowych przepisów prawa żywnościowego pozostanie kluczowe zarówno dla perspektyw utrzymania pozycji sektora na rynku europejskim, jak i zdobywania nowych rynków zbytu poza Europą.

\subsubsection{Znaczenie polityk wspólnotowych i krajowych w stymulowaniu efektywności sektora żywnościowego}

Obok ogólnych czynników makroekonomicznych i instytucjonalnych wpływ na gospodarkę żywnościową mają również polityki sektorowe oraz inne działania państwa skierowane na rozwiązywanie problemów i wyzwań o charakterze ponadsektorowym czy horyzontalnym. Główną polityką sektorową oddziałującą obecnie na gospodarkę żywnościową w Polsce jest Wspólna Polityka Rolna UE, obejmująca - obok zasad regulujących funkcjonowanie wspólnych rynków rolnych - działania skierowane na bezpośrednie wspieranie dochodów rolniczych oraz politykę w zakresie rozwoju obszarów wiejskich. Decyzje dotyczące budżetu WPR oraz jej instrumentów zapadają na szczeblu UE, jednak sposób wdrożenia polityki jest już w dużym stopniu domeną decyzji krajowych. Dodatkowo, ze względu na rosnącą złożoność problemów sektorów rolnych poszczególnych państw członkowskich, zakres elastyczności w ramach WPR wciąż rośnie $^{69}$. Tym samym państwa członkowskie mają stosunkowo duże pole swobody w zakresie realizowania szczegółowych celów rozwojowych czy też stymulowania efektywności sektora. Pozostałe ogniwa łańcucha żywnościowego przedsiębiorstwa przemysłu spożywczego i handlowe - nie są objęte odrębną, dedykowaną im polityką państwa. Na ich funkcjonowanie wpływ ma jednak unijna polityka rolna (poprzez wpływ na produkcję i siłę ekonomiczną gospodarstw rolnych, inwestycje w rozwój obszarów wiejskich, działania skierowane na promocję żywności), polityka spójności (poprzez transfer funduszy strukturalnych UE do gospodarki) oraz inne polityki rozwojowe państwa. W kontekście omawianych w rozdziale trendów w gospodarce światowej związanych z cyfryzacją, szczególnego znaczenia dla całego sektora żywnościowego nabierają

\footnotetext{
${ }^{68}$ The competitive position of the European food and drink industry, Final Report, ECSIP Consortium, Luxembourg: Publications Office of the European Union, 2016.

${ }^{69}$ R. Henke i in., The New Common Agricultural Policy: How do Member States Respond to Flexibility?, „Journal of Common Market Studies” 2017, s. 1-17.
} 
nowe polityki horyzontalne, w tym szczególnie skierowane na wspieranie badań i rozwoju, nowych technologii i innowacji. W ocenie perspektyw rozwoju potencjału konkurencyjnego warto więc przyjrzeć się bliżej nie tylko polityce rolnej i strukturalnej, ale również polityce wspierania innowacji w gospodarce.

Unijna polityka rolna od lat wzbudza wiele kontrowersji - jedną z podstawowych przyczyn jej krytyki jest wysoki odsetek środków budżetowych UE przeznaczanych na bezpośrednie wspieranie dochodów rolniczych. W wyniku reform zapoczątkowanych w latach 90. WPR stopniowo zmienia się - następuje odchodzenie od instrumentów zniekształcających produkcję i handel (m.in. poprzez odejście od kwot produkcyjnych i uniezależnienie płatności bezpośrednich od określonych rodzajów produkcji) i wzmacnianie instrumentów strukturalnych skierowanych na rozwój obszarów wiejskich. Nadal jednak na WPR przeznacza się niemal 40\% całego budżetu UE. Dostępne opracowania i analizy ekonomiczne nie dają jednoznacznych odpowiedzi na pytania o wpływ poszczególnych instrumentów polityki rolnej na konkurencyjność rolnictwa i szerzej sektora rolno-spożywczego. Wynika to m.in. z różnych podejść do mierzenia składowych konkurencyjności oraz różnego rozumienia i definiowania samej konkurencyjności ${ }^{70}$. Niemniej przyjmuje się, że źródłem poprawy konkurencyjności sektora rolnego mogą być: wzrost produktywności czynników produkcji, instytucje wspierające sektor, odpowiednia infrastruktura w zakresie badań i rozwoju, innowacje, edukacja i szkolenia oraz przemiany strukturalne w sektorze ${ }^{71}$. Większość $\mathrm{z}$ tych działań finansowana jest obecnie ze środków II filaru WPR (poświęconego rozwojowi obszarów wiejskich), polityki spójności i polityki naukowo-badawczej. Z kolei ulokowane w I filarze WPR płatności bezpośrednie, jako instrumenty o charakterze dochodowym, mogą poprawiać pozycję konkurencyjną producentów rolnych na rynkach międzynarodowych, nie wspierają jednak rzeczywistej konkurencyjności sektora rolnego. Dominujące wciąż w ramach WPR płatności bezpośrednie prowadzą do pogłębiającego się uzależnienia producentów rolnych od wsparcia państwa i osłabienia efektów oddziaływania instrumentów o charakterze strukturalnym ${ }^{72}$. Choć członkostwo w UE pozwoliło na znaczne zwięk-

\footnotetext{
${ }^{70}$ Przegląd badań w tym obszarze w odniesieniu do sektora rolnego znaleźć można m.in. w opracowaniu L. Latruffe'a. L. Latruffe, Competitiveness, Productivity and Efficiency in the Agricultural and Agri-Food Sectors, „OECD Food, Agriculture and Fisheries Working Papers”, OECD Publishing 2010, nr 30.

${ }^{71} \mathrm{~S}$. Makki, L. Tweeten, C. Thraen, Investing in research and education versus commodity programs: Implications for agricultural productivity, „Journal of Productivity Analysis” 1999, t. 12 , s. $77-94$.

72 S. Tangermann, Direct Payments in the CAP post 2013, document requested by the European Parliament's Committee on Agriculture and Rural Development, IP/B/AGRI/IC/2011_003 PE 438.624, 2011; M. Brady i in., Impacts of decoupled agricultural support on farm structure,
} 
szenie dochodów rolników w Polsce, analizy zasobów pracy i środków trwałych oraz udziału rolnictwa w tworzeniu produkcji globalnej i PKB wskazywały na stosunkowo niewielką produktywność zasobów oraz stagnację w zakresie produktywności pracy w rolnictwie ${ }^{73}$. W tym kontekście można mieć wątpliwości, czy umożliwiona po 2013 roku w ramach mechanizmu elastyczności realokacja środków z II filaru WPR do I filaru i w Polsce wykorzystywana w maksymalnym zakresie $25 \%$ będzie wspierać wzrost produktywności w rolnictwie ${ }^{74}$. Koncentracja działań na płatnościach dochodowych prowadzi do pogłębiania uzależnienia polskich gospodarstw rolnych od wsparcia państwa. Już w tym momencie udział płatności bezpośrednich w dochodach niektórych gospodarstw rolnych w Polsce przekracza $50 \%{ }^{75}$. Rosnąca zależność od instrumentów w niewielkim lub ograniczonym stopniu stymulujących efektywność i konkurencyjność w sektorze jest niekorzystnym zjawiskiem, zwłaszcza w związku z realnym ryzykiem ograniczenia funduszy zarówno WPR, jak i polityki strukturalnej UE po 2020 roku. Ograniczenie środków pomocowych dla sektora może negatywnie wpłynąć nie tylko na przyszłe dochody polskich gospodarstw rolnych, ale również na stabilność bazy surowcowej dla przemysłu spożywczego.

Działania rozwojowe w zakresie badań i innowacji, które mogłyby wzmacniać konkurencyjność sektora rolno-spożywczego w długim okresie czasu są wciąż niewystarczające ${ }^{76}$. Nakłady na działalność badawczo-rozwojową w Polsce należą do jednych z najniższych w UE. W krajach, które znajdują się na podobnym poziomie rozwoju, na ten cel przeznacza się proporcjonalnie dwukrotnie więcej środków ${ }^{77}$. Choć nakłady na badania i rozwój $(\mathrm{B}+\mathrm{R})$ wzrosły w Polsce z poziomu 0,55\% PKB w 2004 roku do 1\% w 2015 roku, dynamika tego wzrostu jest wyraźnie mniejsza niż dynamika wzrostu PKB. Dodatkowo udział nakładów na

biodiversity and landscape mosaic: some EU results, „Journal of Agricultural Economics” 2009, t. 60 , nr 3, s. 563-585.

${ }^{73} \mathrm{M}$. Wigier, The competitiveness of Polish agriculture after accession to the EU, „Economics of Agriculture” („Ekonomika Poljoprivrede”, Belgrade) 2014, vol. 61, nr 1, s. 90.

${ }^{74}$ E. Kawecka-Wyrzykowska, Wsparcie finansowe w ramach Wspólnej Polityki Rolnej dla Polski w latach 2014-2020: ile na poprawe dochodów rolniczych i na wzmacnianie konkurencyjności rolnictwa?, [w:] I. Szczepaniak (red.), Konkurencyjność polskich producentów żywności i jej determinanty (1), seria „Monografie Programu Wieloletniego 2015-2019”, nr 11, IERiGŻ-PIB, Warszawa 2015, s. 86.

${ }^{75}$ Dla niektórych gospodarstw odsetek ten jest jeszcze wyższy, np. w przypadku średnio dużych gospodarstw z chowem bydła rzeźnego, które są zdolne do konkurencji, wynosi $83 \%$. Zob. W. Ziętara i M. Adamski, Konkurencyjność polskich gospodarstw mlecznych i z chowem bydła rzeźnego na tle analogicznych gospodarstw z wybranych krajów, Prezentacja z seminarium IERiGŻ-PIB, Warszawa, 13.10.2017.

${ }^{76}$ Sz. Figiel (red.), Wybrane aspekty innowacyjności w sektorze rolno-spożywczym, seria „Monografie Programu Wieloletniego 2015-2019”, nr 10, IERiGŻ-PIB, Warszawa 2015.

${ }^{77}$ A. Kowalski, Rolnictwo wobec wyzwań..., op. cit., s. 19. 
$\mathrm{B}+\mathrm{R}$ w dziedzinie rolnictwa $\mathrm{w}$ nakładach na B+R ogółem w Polsce spadł z 8,52\% w 2005 roku do 4,55\% w 2015 roku, co oznacza, że na B+R w tym sektorze gospodarki w 2015 roku przeznaczono mniej niż $0,05 \% \mathrm{PKB}^{78}$. Spadek nakładów na działania badawczo-rozwojowe $\mathrm{w}$ rolnictwie był też większy niż spadek udziału wartości dodanej brutto rolnictwa w PKB (w 2005 roku udział ten wynosił 2,9\%, w 2015 roku-2,2\%). Równocześnie, w tym samym czasie, głównie dzięki funduszom unijnym, ale również środkom krajowym, istotnie wzrosło finansowanie płatności bezpośrednich. W rezultacie wydatki na bezpośrednie wsparcie dochodów rolniczych są obecnie niewiele mniejsze niż całkowite nakłady na $\mathrm{B}+\mathrm{R}$ w Polsce (licząc nakłady na B+R sektora rządowego, biznesu, uczelni i organizacji pozarządowych łącznie, wykres 1.4).

Wykres 1.4. Zestawienie wydatków na finansowanie płatności bezpośrednich dla rolników, nakładów na badania i rozwój ogółem oraz badania i rozwój w dziedzinie rolnictwa w Polsce w latach 2005-2015

(w mln euro oraz $\mathrm{B}+\mathrm{R}$ ogółem $\mathrm{i}$ jako proc. $\mathrm{PKB}$ )

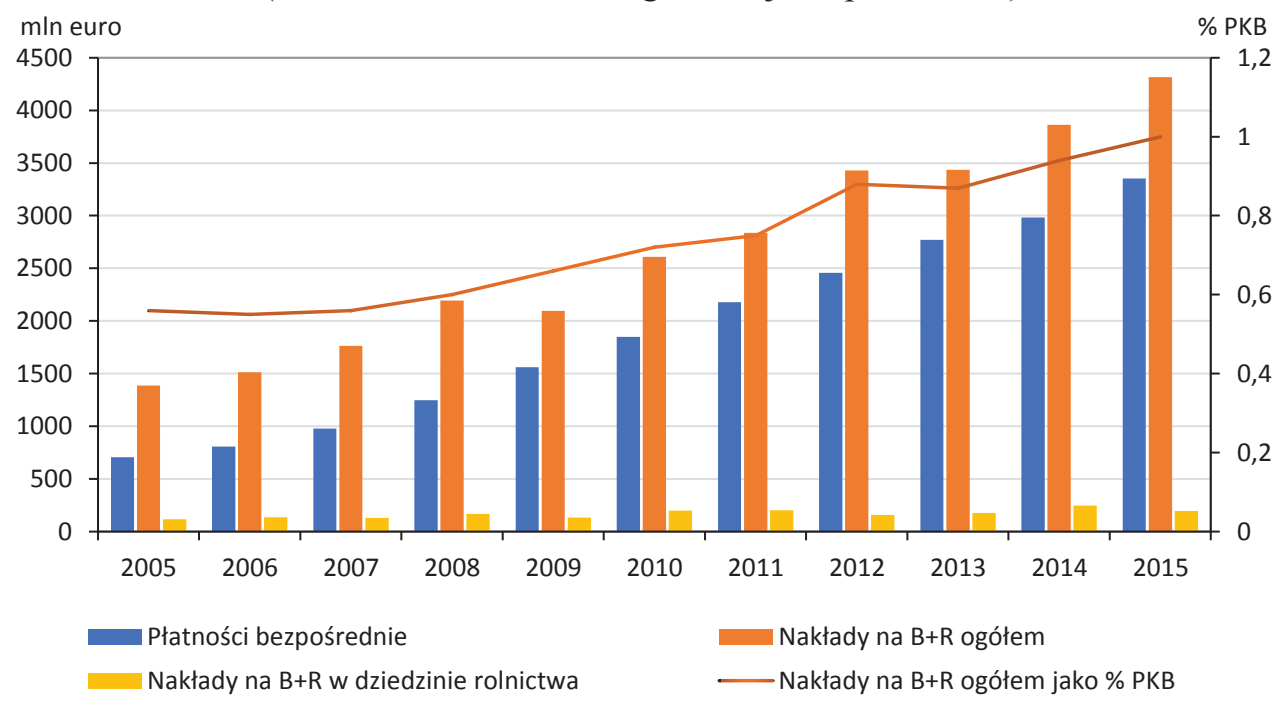

Źródto: dane i obliczenia na podstawie raportów finansowych UE, Eurostatu, GUS i Systemu Monitorowania Rozwoju Strateg.

Ograniczone nakłady na wsparcie prac badawczych, rozwojowych i innowacyjności są charakterystyczne również dla przedsiębiorstw przemysłu spożywczego. Przedsiębiorstwa sektora, podobnie jak inne przedsiębiorstwa w polskiej gospodarce, korzystały ze wsparcia finansowego w ramach najpierw funduszy

\footnotetext{
${ }^{78} \mathrm{Na}$ podstawie danych GUS: https://stat.gov.pl/wskazniki-makroekonomiczne/ i Systemu Monitorowania Rozwoju Strateg: http://strateg.stat.gov.pl.
} 
przedakcesyjnych, a następnie funduszy strukturalnych UE. W związku z koniecznością modernizacji zakładów finansowane projekty koncentrowały się przede wszystkim na inwestycjach w maszyny i urządzenia, w znacznie mniejszym stopniu na wprowadzaniu innowacyjnych technologii czy budowaniu centrów badań i rozwoju. W okresie 2014-2020 ogólna pula wsparcia z funduszy unijnych w ramach polityki spójności ma wynieść dla Polski ponad 82 mld euro. W celu skoncentrowania środków na obszarach, w których Polska może uzyskiwać przewagi konkurencyjne zdecydowano, że preferencje i priorytety w udzielaniu wsparcia dla B+R i innowacji w Polsce powstaną w oparciu o identyfikację inteligentnych specjalizacji. Obecnie sektor rolno-spożywczy jest uwzględniony w krajowych inteligentnych specjalizacjach jako biogospodarka rolno-spożywcza, leśno-drzewna i środowiskowa. W ramach tytułów do wsparcia przewiduje się wsparcie dla innowacyjnych technologii, procesów i produktów sektora rolno-spożywczego i leśno-drzewnego oraz żywności wysokiej jakości. Co istotne, krajowe inteligentne specjalizacje przewidują również wsparcie dla innowacyjnych technologii i procesów przemysłowych w ujęciu horyzontalnym, w tym wsparcie dla sensorów, biosensorów i inteligentnych sieci sensorowych, inteligentnych sieci i technologii geoinformacyjnych, automatyzacji i robotyki procesów technologicznych. Plan na rzecz Odpowiedzialnego Rozwoju przyjęty w 2016 roku przewiduje powstanie do 2020 roku Polskiej Platformy Przemysłu 4.0 ciała koordynacyjnego złożonego z ekspertów i odpowiedzialnego za rozpowszechnianie w polskim przemyśle Internetu Rzeczy. Równocześnie przemysł spożywczy wymieniany jest wśród tych specjalizacji przemysłowych, w których istnieje szansa na uzyskanie wiodącej pozycji na rynku globalnym ${ }^{79}$. Ponadto w programie wspierania inwestycji o istotnym znaczeniu dla gospodarki polskiej na lata 2011-2023 sektor rolno-spożywczy zaliczony został do jednego z ośmiu obszarów priorytetowych.

Można zatem stwierdzić, że na poziomie formułowanych celów plany rozwoju i przekształceń strukturalnych odpowiadają potrzebom wynikającym z ogólnych trendów i zmian w gospodarce światowej. W przypadku sektora żywnościowego problemem jednak nadal pozostają małe nakłady na działalność badawczo-rozwojową i innowacyjną. Nie jest też pewne, do jakiego stopnia i w jakim zakresie projekty z obszaru inteligentnych specjalizacji, w tym kluczowe dla cyfryzacji wsparcie dla technologii innowacyjnych i sztucznej inteligencji, obejmą sektor rolno-spożywczy. Biorąc pod uwagę stosunkowo niewielkie dotychczas zaangażowanie podmiotów sektora w działalność badawczo-rozwojową i w związku z tym mniejsze doświadczenie w zakresie tworzenia i wdrażania

\footnotetext{
${ }^{79}$ Ministerstwo Rozwoju, Plan na rzecz Odpowiedzialnego Rozwoju, Warszawa 2016.
} 
innowacyjnych rozwiązań, a także wciąż dominujące postrzeganie rolnictwa i przemysłu spożywczego jako sektorów niskiej techniki, można mieć obawy, czy dojdzie w najbliższym czasie do jakościowej zmiany w tym obszarze. W samym wykazie krajowych inteligentnych specjalizacji robotyzacja $\mathrm{w}$ przypadku sektora rolnego ograniczona jest do automatyki doju i robotów udojowych. Pominięty jest przy tym potencjał tkwiący w analityce wielkich zbiorów danych, zarówno dla gospodarstw rolnych, jak i innych podmiotów łańcucha żywnościowego. Kluczowe zatem z punktu widzenia wzmacniania skuteczności polityk krajowych i wspólnotowych we wzmacnianiu konkurencyjności sektora byłoby przyjęcie strategii tworzenia w Polsce rolnictwa cyfrowego opartego na Big Data i sztucznej inteligencji oraz równoległe powiązanie wsparcia bezpośredniego w sektorze z działaniami mającymi na celu budowanie zasobów danych cyfrowych w rolnictwie. Podobna strategia dostosowań do epoki 4.0 potrzebna jest również przedsiębiorstwom przemysłu spożywczego.

\subsubsection{Zasoby ludzkie jako klucz do wzmacniania konkurencyjności sektora żywnościowego}

Pomyślna adaptacja do nowych uwarunkowań zewnętrznych w zasadniczym stopniu zależeć będzie od jakości kapitału ludzkiego w sektorze rolno-spożywczym. W 2015 roku w rolnictwie i przemyśle spożywczym zatrudnionych było łącznie ponad 2290 tys. osób (1841 tys. w rolnictwie i ponad 451 tys. w przemyśle spożywczym), co stanowiło łącznie niemal 15\% ogółu zatrudnionych ${ }^{80}$. Pod względem poziomu wykształcenia pracowników sektor rolno-spożywczy nie odróżniał się istotnie od większości pozostałych sektorów rolno-spożywczych w UE. W rolnictwie wykształcenie poniżej podstawowego, podstawowe oraz poniżej zawodowego i średniego posiadało $26 \%$ zatrudnionych, 65\% legitymowało się wykształceniem zawodowym, średnim i powyżej średniego, natomiast $9 \%$ wykształceniem wyższym ${ }^{81}$. W przypadku przemysłu spożywczego dane obejmujące branżę mięsną, mleczarską, owocowo-warzywną i zbożowo-młynarską pokazują wyższy niż w rolnictwie odsetek osób z wykształceniem wyższym (od 10\% w branży mięsnej do niemal 18\% w branży zbożowo-młynarskiej) $)^{82}$. Zdecydowana większość pracowników tych branż posiadała wykształcenie zawodowe, średnie i policealne (średnio powyżej 74\%), najwyższy odsetek osób z wykształceniem podstawowym i gimnazjalnym doty-

\footnotetext{
80 „Rocznik Statystyczny Przemysłu 2016”, GUS, Warszawa 2016.

${ }^{81}$ Dane Labour Force Survey za 2008 rok. Baza danych Eurostatu: http://ec.europa.eu/eurostat/ data/database.

${ }^{82}$ A. Wasilewska, M. Wasilewski, Stan, kierunki i efektywność innowacji w przedsiębiorstwach przetwórstwa rolno-spożywczego, Wydawnictwo SGGW, Warszawa 2016, s. 61.
} 
czył branży owocowo-warzywnej (16,8\%), a najniższy branży mleczarskiej $(8 \%)^{83}$. Generalnie stanowiska menedżerskie w przedsiębiorstwach przemysłu spożywczego, podobnie jak w innych przedsiębiorstwach przemysłowych, obejmowały osoby z wykształceniem co najmniej średnim lub wyższym.

Choć pod względem poziomu wykształcenia pracowników sytuacja sektora rolno-spożywczego mogłaby wydawać się względnie korzystna, dane dotyczące udziału osób dorosłych i osób pracujących ogółem w szkoleniach, edukacji formalnej i nieformalnej świadczą o dużej luce rozwojowej dzielącej Polskę od większości krajów europejskich. W 2016 roku podjęcie edukacji o charakterze formalnym i nieformalnym oraz uczestnictwo w szkoleniach w ciągu ostatniego roku zadeklarowało nieco ponad $32 \%$ pytanych pracowników w Polsce. W tym samym roku odsetek ten wyniósł dla Holandii 73,9\%, a dla Szwecji 66,9\% ${ }^{84}$. Dane te pokazują, że większość pracujących Polaków nie rozwija posiadanych kompetencji i umiejętności, i nie nabywa nowych. Zjawisko to w dobie wykładniczego postępu technologicznego i wzrostu gospodarczego opartego na wiedzy należy uznać za bardzo niekorzystne. $Z$ ogólnoeuropejskich badań przeprowadzonych wiosną 2017 roku wynika, że w Polsce wiedza na temat roli i możliwych zastosowań rozwiązań cyfrowych i sztucznej inteligencji w praktyce życia gospodarczego i społecznego jest stosunkowo niewielka. W Holandii i Szwecji 8 na 10 respondentów zetknęło się w ciągu ostatnich 12 miesięcy z informacją na temat sztucznej inteligencji i jej zastosowań. Polska znalazła się pod tym względem na jednym z ostatnich miejsc w UE - zaledwie 28\% pytanych Polaków czytało bądź słyszało o sztucznej inteligencji i cyfryzacji w gospodarce ${ }^{85}$. Jak wynika z raportu analityków McKinsey, najbardziej świadome i otwarte na stosowanie cyfrowych technologii, robotów, automatyzacji i sztucznej inteligencji w życiu codziennym i w pracy są obecnie społeczeństwa takich krajów Europy, jak: Belgia, Dania, Estonia, Finlandia, Holandia, Irlandia, Luksemburg, Norwegia i Szwecja ${ }^{86}$.

Indeks DESI mierzący poziom cyfryzacji społeczeństwa i gospodarki wskazuje, że Polska jest obecnie jednym z najsłabiej rozwiniętych pod względem cyfrowym państw członkowskich UE. Choć systematycznie rośnie wykorzystanie komputerów i Internetu, ogólny poziom umiejętności cyfrowych - na tle innych państw członkowskich Unii Europejskiej - pozostaje niski. W 2016 roku

\footnotetext{
${ }^{83}$ Ibid.

${ }^{84}$ Baza danych Eurostatu: http://ec.europa.eu/eurostat/data/database.

${ }^{85}$ Attitudes towards the impact of digitisation and automation on daily life, Special Eurobarometer 460, May 2017.

${ }^{86}$ Shaping the future of work in Europe's digital front-runners, McKinsey Global Institute, October 2017.
} 
umiejętnościami cyfrowymi na poziomie wyższym niż podstawowy (a więc takim, który pozwala w zagregowanym ujęciu wykorzystywać technologię do zwiększania produktywności i osiągania wzrostu gospodarczego) legitymowało się niecałe 20\% mieszkańców Polski. Wynik ten znacznie odbiegał od wyników w Luksemburgu (54,2\%), Danii (53\%), Holandii $(44,9 \%)$ czy Finlandii $(43,7 \%)^{87}$. Dodatkowo kompetencje cyfrowe ludności na obszarach wiejskich w Polsce były niższe niż kompetencje cyfrowe ludności ogółem. Kompetencjami cyfrowymi na poziomie łącznie podstawowym i ponadpodstawowym legitymowało się $36 \%$ mieszkańców obszarów wiejskich wobec 44\% ogółu Polaków. Można przypuszczać, że odsetek rolników posiadających podstawowe i ponadpodstawowe umiejętności cyfrowe jest jeszcze niższy niż odpowiedni odsetek mieszkańców obszarów wiejskich. Kluczowe dla poprawy perspektyw przyjęcia i stosowania nowych rozwiązań technologicznych i cyfrowych w sektorze rolno-spożywczym będą więc nie tylko kampanie edukacyjne i informacyjne na temat możliwości, jakie epoka 4.0 oferuje w zakresie stymulowania efektywności, poprawy dochodów i wzrostu gospodarczego, ale równoczesne rozwijanie i pogłębianie ponadpodstawowych umiejętności cyfrowych wśród rolników, i szerzej pracowników sektora rolno-spożywczego.

Obecny ograniczony poziom kompetencji i umiejętności cyfrowych może przekładać się na ogólną niechęć do zmian i innowacji cyfrowych w rolnictwie. Badania przeprowadzone wśród rolników do 40. roku życia w regionach południowej Polski i dotyczące ogólnie innowacji w sektorze pokazują, że choć rolnicy generalnie nie odrzucali zmian, podchodzili do nich $\mathrm{z}$ rezerwą ${ }^{88}$. Wśród przebadanych rolników dominowały osoby ( $2 / 3$ badanych), które - zgodnie z terminologią Rogersa - można określić mianem „wczesnej większości”, a więc osoby, które niezbyt chętnie wprowadzają zmiany i nadążają za nimi. Jedynie 1/3 badanych można było określić mianem „wcześnie przyswajających”, a więc osób, które łatwo przyswajają nowości oraz są ich zwolennikami. W badanej grupie nie było jednak pionierów (innowatorów), którzy są najcenniejszym zasobem ludzkim w procesie dyfuzji innowacji, nie było również „maruderów”, a więc osób, które nie widzą potrzeby wprowadzania zmian ${ }^{89}$. Warto jednak zaznaczyć, że przywołana grupa obejmowała gospodarstwa z regionów Polski południowej i wyłącznie młodych rolników, którzy - jak można przypuszczać mają bardziej otwarty stosunek do zmian i innowacji niż ludzie starsi. Choć od-

\footnotetext{
${ }^{87}$ Digital Scoreboard - Data \& Indicators: http://digital-agenda-data.eu.

${ }^{88}$ B. Kiełbasa, J. Puchała, Innowacyjność młodych rolników i ich postawy wobec zmian na przykładzie gospodarstw rolnych położonych $w$ regionie rozdrobnionego rolnictwa, „Roczniki Naukowe Stowarzyszenia Ekonomistów Rolnictwa i Agrobiznesu” 2015, t. XVII, z. 1, s. 107-111. ${ }^{89}$ Ibid.
} 
setek młodych rolników w Polsce jest wyraźnie wyższy niż w pozostałych państwach UE, nadal większość gospodarstw rolnych w Polsce prowadzą ludzie starsi ${ }^{90}$. Poziom akceptacji dla nowych technologii cyfrowych w rolnictwie może być jednak zróżnicowany - zależeć będzie zapewne nie tylko od wieku właścicieli gospodarstw rolnych, ale również od poziomu wykształcenia, wielkości gospodarstw, ich sytuacji dochodowej i dostępu do usług szkoleniowych i doradczych. Można przypuszczać, że gospodarstwa największe, prowadzone przez młodych, wykształconych i kształcących się rolników, będą najchętniej wdrażać cyfrowe innowacje. Warto jednak w tym miejscu podkreślić, że cyfryzacja rolnictwa może przynosić wymierne korzyści nie tylko dużym gospodarstwom, ale również gospodarstwom mniejszym, w tym gospodarstwom funkcjonującym $\mathrm{w}$ regionach o największym rozdrobnieniu struktury agrarnej.

Równie duże, jeśli nie większe, korzyści z cyfryzacji dotyczą pozostałych ogniw łańcucha żywnościowego, w tym także przedsiębiorstw przemysłu spożywczego. Biorąc pod uwagę wyniki poprzednich badań, można spodziewać się, że podmioty przemysłu spożywczego będą bardziej pozytywnie podchodzić do szans oferowanych przez innowacje cyfrowe. $\mathrm{Z}$ badań przeprowadzonych przez K. Firleja i D. Żmiję obejmujących lata 2007-2012 wynika, że przemysł spożywczy był generalnie sektorem innowacyjnym i wdrażającym elementy zarządzania wiedzą ${ }^{91}$. Menedżerowie badanych przez autorów spółek należących do sektora spożywczego Warszawskiej Giełdy Papierów Wartościowych pozytywnie odnosili się do stosowania informatycznych narzędzi wspomagających zarządzanie wiedzą, wskazując, że może to być ważne źródło przewagi konkurencyjnej. Niektórzy z nich byli również otwarci na korzystanie z usług firm doradczych zajmujących się wdrażaniem systemów wspomagających proces zarządzania i planowania zasobów przedsiębiorstwa. Należy jednak podkreślić, że pozytywny stosunek do zmian i innowacji niekoniecznie przekładał się na praktyczne działania w postaci wypracowanych strategii innowacyjnych czy zwiększonych nakładów inwestycyjnych w tym obszarze. Badania przeprowadzone przez K. Firleja w 2012 i 2013 roku, obejmujące wszystkie przedsiębiorstwa przemysłu spożywczego w Polsce, pokazują, że poziom wiedzy i dy-

\footnotetext{
${ }^{90}$ Rolnicy do 35 roku życia w 2013 roku stanowili niemal 12\% wszystkich rolników w Polsce, średnia dla UE-28 w tym samym roku wyniosła 6\%. Wliczając do kategorii młodych rolników również osoby do 44 roku życia, odsetek dla Polski wzrasta do 36\%. Rolnicy w kategoriach wiekowych od 45 do 54 roku życia, od 54 do 65 roku życia i powyżej 65 roku życia prowadzili łącznie ponad 63\% wszystkich gospodarstw rolnych w Polsce. Baza danych Eurostatu: http://ec.europa.eu/eurostat/data/database.

${ }^{91}$ K. Firlej, D. Żmija, Transfer wiedzy $i$ dyfuzja innowacji jako źródło konkurencyjności przedsiębiorstw przemystu spożywczego w Polsce, Fundacja Uniwersytetu Ekonomicznego w Krakowie, Kraków 2014.
} 
fuzja innowacji nie ogrywały głównej roli w funkcjonowaniu przedsiębiorstw tego sektora ${ }^{92}$. Procesy innowacji miały często charakter incydentalny i w głównej mierze kształtowane były przez czynniki wewnętrzne i najbliższe otoczenie przedsiębiorstwa. Swoją pozycję konkurencyjną polski przemysł spożywczy budował przede wszystkim w oparciu o strategie kosztowo-cenowe - niskie koszty pracy i szeroki dostęp do surowców pochodzących z krajowego rolnictwa ${ }^{93}$. Wobec zmieniających się uwarunkowań zewnętrznych strategia ta de facto nie wzmacnia już potencjału konkurencyjnego polskiego przemysłu spożywczego ${ }^{94}$. Dla jego wzmocnienia pożądana byłaby zarówno zwiększona orientacja na wdrażanie innowacji procesowych, produktowych, marketingowych i organizacyjnych, jak i towarzyszące temu zwiększone inwestycje w rozwój zasobów ludzkich w przedsiębiorstwach sektora, pozwalające na budowanie trwałych podstaw dla rozwoju innowacyjności i przewag konkurencyjnych na rynkach międzynarodowych.

Obecnie przemysł spożywczy w Polsce, jak również w Europie, stoi przed dużym wyzwaniem przyciągnięcia pracowników o wysokich kompetencjach, które dotąd w sektorze nie były często spotykane (m.in. pracowników z kompetencjami cyfrowymi, specjalistów ICT, specjalistów z zakresu nauk behawioralnych, genetyki) ${ }^{95}$. Znaczące zasoby wykształconej siły roboczej wskazują, że Polska ma dobrą pozycję startową, by wykorzystać szanse związane z rewolucją cyfrową $^{96}$. W latach 1998-2012 studia wyższe ukończyło w Polsce 7,2 mln osób, w tym kierunki ścisłe (STEM - science, technology, engineering, mathematics) 800 tys. osób. Pod względem zarówno liczby absolwentów kierunków ścisłych, jak i liczby absolwentów studiów informatycznych (185 tys.) Polska plasuje się na czwartym miejscu w UE, po Niemczech, Wielkiej Brytanii i Francji ${ }^{97}$. Mimo to odsetek przedsiębiorstw prowadzących np. analizy Big Data wciąż jest w Polsce niewielki. W 2015 roku takie analizy prowadziło 5,9\% ogółu przedsiębiorstw

\footnotetext{
${ }^{92}$ K. Firlej, Wzrost konkurencyjności przedsiębiorstw przemystu spożywczego poprzez doskonalenie działań w obszarze zarządzania wiedza, [w:] I. Szczepaniak (red.), Monitoring i ocena konkurencyjności polskich producentów żywności (3). Potencjat konkurencyjny - wybrane elementy, seria „Program Wieloletni 2011-2014”, nr 73, IERiGŻ-PIB, Warszawa 2013, s. 101-112. ${ }^{93}$ K. Firlej, A. Kowalska, A. Piwowar, Competitiveness and innovation of the Polish food industry, „Agricultural Economics” 2017, nr 63(11), s. 502-509.

${ }^{94}$ I. Szczepaniak, Uwarunkowania zewnętrzne konkurencyjności polskich producentów żywności, [w:] I. Szczepaniak (red.), Konkurencyjność polskich producentów żywności i jej determinanty (1), seria „Monografie Programu Wieloletniego 2015-2019”, nr 11, IERiGŻ-PIB, Warszawa 2015, s. 66.

${ }^{95}$ The competitive position of the European food..., op. cit.

${ }^{96}$ Cyfrowa Polska. Szansa na technologiczny skok do globalnej pierwszej ligi gospodarczej, Raport McKinsey\&Company we współpracy z Forbsem, 2016.

${ }^{97}$ Ibid.
} 
i $17,6 \%$ przedsiębiorstw dużych. Były to głównie podmioty z branż informacji i komunikacji, IT, energii i sektora utilities. Udział podmiotów z branży przetwórstwa przemysłowego korzystających z wiedzy płynącej z wielkich wolumenów danych cyfrowych był dużo niższy $(4,7 \%)^{98}$. Wobec spodziewanego wzrostu popytu na zaawansowane kompetencje cyfrowe ze strony wszystkich sektorów i branż można mieć obawy, czy sektor rolno-spożywczy będzie atrakcyjnym miejscem pracy dla specjalistów ICT. Najprawdopodobniej jedynie duże przedsiębiorstwa przemysłu spożywczego będą mogły przyciągać pracowników posiadających kompetencje wymagane w związku z rozwojem Przemysłu 4.0. Można spodziewać się, że cyfryzacja i robotyzacja zmienią rynek pracy ${ }^{99}$. Z jednej strony niektóre zawody i stanowiska pracy okażą się zbędne, z drugiej strony pojawią się nowe potrzeby i nowe zawody wymagające odpowiednich kompetencji cyfrowych.

\subsection{Podsumowanie}

Światowa gospodarka wkracza w nowy etap rozwoju charakteryzujący się coraz bardziej intensywnymi przepływami danych i informacji. Postępująca cyfryzacja wielu dziedzin życia, inteligentne technologie oraz zaawansowane algorytmy pozwalają obecnie uzyskiwać nową wiedzę i kluczowe dla podmiotów gospodarczych informacje w czasie rzeczywistym. W takim środowisku można reagować na potrzeby konsumentów i zmieniające się sygnały rynkowe znacznie szybciej niż jeszcze kilka lat temu. Można też lepiej planować i zarządzać ryzykiem w procesie produkcji oraz zwiększać produktywność posiadanych zasobów. Procesy te już teraz zmieniają i nadal będą zmieniać krajobraz konkurencji na rynku. Konkurencyjność w czasach globalizacji cyfrowej będzie najprawdopodobniej rozwijać się skokowo, nie liniowo. Zdobycie bądź utrzymanie dobrej pozycji na rynku zależeć będzie nie tylko od odpowiedniego ekosystemu i infrastruktury cyfrowej, ale również od przyjmowania i stosowania elastycznych, zwinnych metod zarządzania oraz innowacyjnych modeli biznesowych.

Przyspieszającej na skutek cyfryzacji globalizacji w sferze gospodarczej nie towarzyszy odpowiednia integracja w sferze politycznej. Obserwowane są wręcz odwrotne zjawiska - w siłę rosną radykalne ruchy narodowe, narastają separatyzmy krajowe i tendencje dezintegracyjne, słabnie znaczenie organizacji międzynarodowych. Zjawiska te w dużej mierze są efektem dynamiki procesów

\footnotetext{
${ }^{98}$ Spoleczeństwo informacyjne w Polsce. Wyniki badań statystycznych z lat 2012-2016, GUS, Warszawa 2016.

${ }^{99}$ C.B. Frey, M.A. Osborne, The future of employment: how susceptible are jobs to computerisation?, „Technological Forecasting and Social Change” 2017, t. 114, nr C, s. 254-280.
} 
globalizacyjnych poprzedniej epoki, które pogłębiały podziały w społeczeństwach różnych państw, a także między nimi. Nie wiadomo, czy nowe szanse związane z globalizacją cyfrową pozwolą na rozładowanie istniejących napięć. Nie wiadomo również, czy wspólnota międzynarodowa zdoła wypracować wspólny reżim zapobiegający zjawiskom wykluczenia cyfrowego poszczególnych państw. W sytuacji utrzymującego się kryzysu instytucji międzynarodowych narastanie napięć politycznych może jednak przekładać się na gorsze perspektywy rozwoju międzynarodowej wymiany handlowej i tym samym gorsze perspektywy budowania przewag konkurencyjnych poszczególnych państw, sektorów i branż.

Duża dynamika zmian w otoczeniu międzynarodowym oraz nowe osiągnięcia $\mathrm{w}$ dziedzinie technologii informacyjno-komunikacyjnych pokazują skalę i charakter wyzwań, jakie stoją przed polskim sektorem rolno-spożywczym w najbliższej przyszłości. Można przyjąć, że wzmacnianie potencjału konkurencyjnego sektora zależeć będzie od umiejętności odnalezienia się i funkcjonowania $\mathrm{w}$ ramach wskazanych wyżej procesów i sił o często przeciwnych wektorach. Pewnym ograniczeniem pozostaje dominujące podejście i postrzeganie sektora rolno-spożywczego jako sektora niskiej techniki, w którym mogą i powinny być stosowane głównie tradycyjne metody produkcji. Niewątpliwie jednak w nieodległej przyszłości na produktywność i związaną z nią konkurencyjność duży wpływ będzie miał zakres wykorzystania zdobyczy rewolucji informatycznej i digitalizacji w rolnictwie i przemyśle spożywczym. Rozpowszechnienie rolnictwa precyzyjnego i innowacyjnych rozwiązań technologicznych opartych na wykorzystaniu danych rolniczych i pozarolniczych do sterowania procesami produkcji, przetwórstwa, dystrybucji i sprzedaży produktów rolno-spożywczych może w sposób istotny wpłynąć na produktywność w sektorze żywnościowym oraz wzmocnić jego pozycję konkurencyjną na rynkach międzynarodowych.

Nowe tendencje widoczne są również w funkcjonowaniu łańcuchów żywnościowych. Pojawiają się w nich nowe podmioty, niekojarzone dotąd ani z rolnictwem, ani z przemysłem spożywczym, czy tradycyjnym handlem. Dalsza penetracja łańcucha żywnościowego przez firmy spoza sektora żywnościowego, w tym głównie firmy IT i firmy sektora wysokich technologii dostarczające usługi i aplikacje dla producentów i konsumentów, może tworzyć nowy układ sił w sektorze, decydujący o większych lub mniejszych przewagach konkurencyjnych w przyszłości. Konkurencyjność gospodarek żywnościowych w takich uwarunkowaniach zależeć będzie od możliwości i otwartości na przekształcenia tradycyjnych relacji w łańcuchu żywnościowym obejmujących rolnictwo, przetwórstwo, handel i konsumentów w system sieciowych i ponadsektorowych relacji 
dostosowanych do potrzeb cyfrowej gospodarki. Można przypuszczać, że sprawna komunikacja skracająca dystans między producentami żywności i konsumentami stanie się jednym z ważniejszych źródeł przewag konkurencyjnych w sektorze.

Analiza sytuacji sektora żywnościowego w Polsce z perspektywy konkurencyjności systemowej pozwoliła zidentyfikować czynniki zarówno o pozytywnym, jak i negatywnym wpływie na jego potencjał konkurencyjny w kontekście wyzwań związanych z globalizacją i cyfryzacją gospodarki. W analizie uwzględnione zostały czynniki społeczne o charakterze strukturalnym (wartości i normy społeczne), czynniki makroekonomiczne i polityczne związane z funkcjonowaniem zarówno instytucji w państwie, jak i prowadzonymi przez państwo politykami, oraz czynniki społeczne na poziomie mikroekonomicznym związane ze stanem zasobów ludzkich i potencjałem kapitału ludzkiego w sektorze żywnościowym. Najważniejsze wnioski płynące $\mathrm{z}$ analizy znajdują się poniżej:

- Na metapoziomie podstawową barierą wzmacniania potencjału konkurencyjnego sektora żywnościowego pozostaje niski poziom kapitału społecznego i zaufania w Polsce. Widoczne deficyty w tym obszarze nie sprzyjają dyfuzji innowacji i zmianom. Poprawa perspektyw możliwie pełnego wykorzystania szans związanych z rewolucją cyfrową wymagałaby, szczególnie w przypadku rolnictwa, zwiększenia wysiłków na rzecz budowania lokalnych grup współpracy, koniecznych do tworzenia wspólnych platform i zasobów danych cyfrowych w sektorze.

- Sytuacja makroekonomiczna pozytywnie wpływała na konkurencyjność gospodarki żywnościowej w Polsce. Przyczyniały się do tego m.in. stały realny wzrost PKB na mieszkańca, stabilna polityka monetarna i utrzymywanie dyscypliny w finansach publicznych. Obecne uwarunkowania makroekonomiczne wciąż sprzyjają utrzymywaniu przewag cenowych polskiego sektora rolno-spożywczego. Można jednak spodziewać się, że przewagi te będą stopniowo zanikać w związku ze spodziewanym wzrostem kosztów pracy w Polsce.

- Uwarunkowania polityczne na poziomach makro i mezo związane z funkcjonowaniem instytucji i politykami prowadzonymi przez państwo miały zróżnicowany wpływ na konkurencyjność polskiej gospodarki żywnościowej. Negatywnie na konkurencyjność wpływała stosunkowo duża zmienność krajowego otoczenia regulacyjnego, $z$ drugiej strony pozytywne impulsy płynęły ze strony regulacji przyjmowanych na szczeblu europejskim. Polityki sektorowe nie zapewniały dostatecznego wsparcia dla badań, rozwoju i innowacji w sektorze. W tym kontekście warto zastanowić się nad przyszłością płatności bezpośrednich dla rolników oraz nad możliwościami powiązania ich w jakimś zakresie z działaniami na rzecz budowy zasobów danych cyfrowych w rolnictwie. 
- Zasoby ludzkie w sektorze żywnościowym nie są dostosowane do wymogów epoki cyfrowej. Obecnie niski poziom kompetencji cyfrowych i wiedzy może opóźniać cyfrową transformację w sektorze. Kluczowe dla poprawy perspektyw wzmacniania konkurencyjności sektora byłyby zwiększone inwestycje w rozwój kompetencji cyfrowych i kampanie edukacyjne dotyczące możliwości wykorzystania zdobyczy rewolucji cyfrowej w praktyce życia społecznego i gospodarczego; pozytywnym zjawiskiem, z punktu widzenia potencjału kapitału ludzkiego w Polsce, jest stosunkowo duża liczba absolwentów kierunków ścisłych i informatycznych.

Podsumowując, sektor rolno-spożywczy stoi przed ogromnymi wyzwaniami dostosowania się do nowych uwarunkowań zewnętrznych związanych z rozwojem nowych technologii o potencjalnie dużym wpływie na kształtowanie przewag konkurencyjnych w przyszłości. Równocześnie stoi przed nowymi barierami wynikającymi z narastających nacjonalizmów i obecnych tendencji do dezintegracji na poziomie Unii Europejskiej. W obecnej sytuacji ewentualny kryzys instytucji europejskich może negatywnie oddziaływać na perspektywy rozwoju wspólnego rynku i wspólnych polityk, a tym samym na perspektywy rozwoju polskiego agrobiznesu. Istotne z punktu widzenia wzmacniania potencjału konkurencyjnego polskiego sektora rolno-spożywczego byłoby więc nie tylko wypracowanie strategii cyfryzacji dedykowanej stricte sektorowi, ale również zacieśnianie współpracy w Europie oraz głębsze zaangażowanie w działania wzmacniające instytucje europejskie. 


\section{Przewagi komparatywne w polskim handlu produktami rolno-spożywezymi}

\subsection{Wprowadzenie}

Pojęcie przewagi komparatywnej (względnej) do ekonomii międzynarodowej wprowadził na początku XIX wieku przedstawiciel nurtu klasycznego, brytyjski ekonomista D. Ricardo. Podejście, według którego siłą sprawczą handlu międzynarodowego jest wyłącznie występowanie różnic we względnych, a nie absolutnych kosztach wytwarzania, które są mierzone wielkością nakładów pracy na jednostkę produktu, innymi słowy zróżnicowanie wydajności pracy w skali międzynarodowej, znane jest $\mathrm{w}$ literaturze przedmiotu jako model ricardiański ${ }^{100}$. Zgodnie z tym modelem handel między dwoma krajami może być dla obu krajów korzystny, jeśli każdy z nich eksportuje dobra, w produkcji których ma przewagi komparatywne. Kraj zaś ma przewagę komparatywną w produkcji jakiegoś dobra wtedy, kiedy koszt względny (,niekoniecznie absolutny”) produkcji w przeliczeniu na inne dobra jest niższy w tym kraju niż w innych krajach. Kraj ten eksportuje dobra, które może wyprodukować po niższych kosztach względnych, a importuje dobra, które w innym przypadku wyprodukowałby po wyższych kosztach. Różnica w kosztach względnych stwarza możliwość osiągnięcia obustronnych korzyści ${ }^{101}$. Handel międzynarodowy powoduje zatem zwiększenie światowej produkcji dlatego, że pozwala krajom specjalizować się w wytwarzaniu dóbr, w których mają przewagi komparatywne. W takiej sytuacji każdy kraj uczestniczący w wymianie międzynarodowej osiąga wymierne korzyści, tj. rozmiary produkcji w każdym z tych krajów są większe, niż gdyby nie było handlu między nimi.

Według tej teorii dany kraj może mieć przewagę komparatywną i odnosić korzyści z handlu nawet wtedy, gdy nie posiada absolutnej przewagi w produkcji żadnego $\mathrm{z}$ dóbr ${ }^{102}$. Wystarczy, żeby posiadał relatywną przewagę $\mathrm{w}$ produkcji wybranego towaru, aby mógł być jego eksporterem. W teorii tej nie porównuje się zatem poziomu jednostkowych kosztów produkcji tego samego towaru w dwóch krajach, lecz porównuje się stosunek jednostkowych kosztów produkcji wybranych dwóch produktów w dwóch krajach.

\footnotetext{
${ }^{100}$ P.R. Krugman, M. Obstfeld, Ekonomia międzynarodowa. Teoria i praktyka, t. 1, Wydawnictwo Naukowe PWN, Warszawa 2007, s. 42-44.

${ }^{101}$ T.A. Pugel, International Economics, McGraw-Hill, International Edition, 2012, s. 37.

102 Ibid., s. 40.
} 
Zasada kosztów względnych wielokrotnie poddawana była jednak weryfikacji. Jedna z najbardziej znanych prób weryfikacji tej zasady, oparta na analizie eksportu i wydajności pracy, została podjęta przez G.D.A. MacDougalla, który w 1951 roku objął szczegółową analizą obroty handlowe między Stanami Zjednoczonymi a Wielką Brytanią. Przeprowadzona analiza potwierdziła słuszność teorii D. Ricardo. Podobnie badania empiryczne przeprowadzone w latach następnych przez innych ekonomistów, m.in. R.M. Sterna [1962] i B. Balassę [1963], potwierdziły słuszność teorii kosztów komparatywnych ${ }^{103}$.

Zasada przewag komparatywnych autorstwa D. Ricardo, pierwotnie mająca charakter statyczny, uwzględniająca tylko dwa towary oraz jeden czynnik wytwórczy „praca”, będąc przedmiotem dociekań wielu ekonomistów, doczekała się wielu modyfikacji. R. Dornbusch, S. Fischer i P.A. Samuelson [1977] rozszerzyli ją na większą liczbę dóbr, a m.in. J. Viner [1960] i D.M. Schydlowsky [1984] zaproponowali zwiększenie liczby czynników wytwórczych ${ }^{104}$. Z kolei G. Haberler [1950] i wielu innych później (m.in. T.A. Pugel ${ }^{105}$ ) twierdzili, że analizując przewagi komparatywne poszczególnych krajów w handlu międzynarodowym, należy brać pod uwagę koszty alternatywne, które powstają w związku z rezygnacją z produkcji jednego dobra po to, by wytworzyć drugie dobro. Każdy kraj powinien bowiem specjalizować się w produkcji i handlu produktami, w przypadku których ma względną przewagę mierzoną relatywnie niższymi kosztami alternatywnymi ${ }^{106}$.

Dynamiczne ujęcie zasady przewag komparatywnych umożliwiło natomiast tworzenie różnorodnych modeli międzynarodowej konkurencyjności gospodarki narodowej (m.in. M. Guzka [1967, 2001], T. Griesa, C. Hentschela i B. Wiggera [1992], F. Ezeala-Harrisona [1999, 2005], E. Siggela [2006] ${ }^{107}$ ). Modele te, nawiązując do zasady kosztów względnych D. Ricardo, koncentrują się na analizowaniu zagranicznej wymiany handlowej poszczególnych krajów w przeszłości i możliwościach kształtowania się jej w przyszłości. Są to zatem w dużej mierze modele o charakterze ex ante. Zdaniem J. Misali wymiana między-

\footnotetext{
${ }^{103}$ A. Budnikowski, Międzynarodowe stosunki gospodarcze, Polskie Wydawnictwo Ekonomiczne, Warszawa 2003, s. 56-57; A. Budnikowski, Ekonomia międzynarodowa, Polskie Wydawnictwo Ekonomiczne, Warszawa 2017, s. 64-65.

${ }^{104}$ A. Budnikowski, Międzynarodowe stosunki..., op. cit., s. 52-56; J. Misala, Międzynarodowa konkurencyjność gospodarki narodowej, Polskie Wydawnictwo Ekonomiczne, Warszawa 2011, s. 190-191; B. Ślusarczyk, Międzynarodowa pozycja konkurencyjna Polski. Teoria i praktyka, Wydawnictwa Fachowe CeDeWu.PL, Warszawa 2011, s. 64.

${ }^{105}$ T.A. Pugel, International..., op. cit., s. 40.

${ }^{106}$ J. Misala, Historia rozwoju teorii i polityki konkurencyjności międzynarodowej, Wydawnictwo Szkoły Głównej Handlowej, Warszawa 2009, s. 76.

${ }^{107}$ J. Misala, Międzynarodowa konkurencyjność..., op. cit., s. 191-203.
} 
narodowa poszczególnych krajów odzwierciedla kondycje ich gospodarek narodowych, podczas gdy sama konkurencyjność w tych modelach - mimo ich wielu zalet - traktowana jest raczej drugorzędnie ${ }^{108}$.

D. Ricardo abstrahował w swoich rozważaniach od problemu wartości międzynarodowej i relacji w wymianie między krajami. Nie wyjaśniał także determinant podziału korzyści z handlu międzynarodowego. Mimo tych i innych mankamentów oraz przyjętych założeń upraszczających zasada kosztów komparatywnych stała się fundamentem rozwoju teorii międzynarodowych stosunków gospodarczych $^{109}$. Dwa podstawowe wnioski płynące z tej zasady - że różnice w wydajności pracy odgrywają istotną rolę w handlu międzynarodowym oraz że znaczenie mają przewagi komparatywne, nie zaś absolutne - wydają się bowiem być niezaprzeczalne ${ }^{110}$.

Obok przewag komparatywnych typu ricardiańskiego w literaturze funkcjonuje drugi typ przewag komparatywnych, tj. przewagi typu B. Balassy ${ }^{111}$. M. Guzek porównując oba rodzaje przewag, stwierdza, że: „Przewaga komparatywna w sensie ricardiańskim wynika z kryterium opłacalności eksportu danej dziedziny w porównaniu z innymi dziedzinami i jednocześnie w porównaniu z zagranicą. Niska przewaga komparatywna nie oznacza jednak, że dany towar nie może być eksportowany. Należy ją interpretować jako wskaźnik świadczący o niskiej predyspozycji specjalizacyjnej w porównaniu z innymi krajami. Przewaga komparatywna typu Balassy wynika natomiast z zastosowania kryterium wielkości eksportu w porównaniu z innymi dziedzinami i jednocześnie z zagranicą"112. W ujęciu B. Balassy wysokie przewagi mogą zatem ujawniać się nie tylko przy wysokiej opłacalności produkcji i eksportu określonej grupy produktów danego kraju, ale także przy niskiej ich opłacalności (lub jej braku). Analizę przewag komparatywnych w tym ujęciu można traktować jako przybliżenie zdolności danego kraju do konkurowania w handlu międzynarodowym, a jednocześnie podstawę do oceny aktualnej pozycji konkurencyjnej tego kraju i jej zmian w przeszłości. $Z$ tego też powodu J. Misala uważa, że przewagi komparatywne w tym ujęciu są raczej przewagami konkurencyjnymi ${ }^{113}$.

\footnotetext{
${ }^{108}$ Ibid., s. 191-203.

${ }^{109}$ K. Pawlak, W. Poczta, Międzynarodowy handel rolny, Polskie Wydawnictwo Ekonomiczne, Warszawa 2011, s. 18.

${ }^{110}$ P.R. Krugman, M. Obstfeld, Ekonomia..., op. cit., s. 70.

111 B. Balassa, Trade Liberalization and Revealed Comparative Advantage, The Manchester School, vol. 33, 1965, s. 99-123.

${ }^{112}$ M. Guzek, Międzynarodowe stosunki gospodarcze. Zarys teorii i praktyki handlowej, Wydawnictwo Wyższej Szkoły Bankowej w Poznaniu, Poznań 2004, s. 49.

${ }^{113}$ J. Misala, Międzynarodowa konkurencyjność..., op. cit., s. 166.
} 
Nieustannie rozwijana metoda B. Balassy i zaproponowane przez niego wskaźniki stanowią „współcześnie kanon badań międzynarodowej zdolności konkurencyjnej w sferze handlu międzynarodowego i szerzej rozumianej wymiany międzynarodowej"114.

Międzynarodowa konkurencyjność jest nie tylko kategorią dynamiczną, ale także miarą relatywną, co oznacza, że jej poziom i zmiany zawsze należy rozpatrywać na ściśle określonym tle ${ }^{115}$. W związku z tym do wnioskowania o pozycji konkurencyjnej danej grupy produktów czy sektora gospodarki należy wykorzystywać miary, które porównują je z innymi grupami produktów czy sektorami. Ten postulat spełnia wskaźnik ujawnionych przewag komparatywnych proponowany przez $\mathrm{B}$. Balassę, jak również inne wskaźniki, będące jego kolejnymi modyfikacjami. Potwierdza to E. Siggel, pisząc, że miernik B. Balassy „odzwierciedla sukces w eksporcie krajów względem świata jako całości”"

W badaniu, którego wyniki przedstawiono w niniejszym rozdziale, przeprowadzono analizę przewag komparatywnych w polskim handlu produktami rolno-spożywczymi na kilku wybranych rynkach, tj. na rynku światowym, rynkach państw UE-15 i UE-13 oraz na rynkach krajów spoza UE, w latach 2004-2016. Ocenę przewag komparatywnych poprzedzono omówieniem ewolucji metod badania przewag komparatywnych, które zaowocowało wyborem wskaźnika relatywnej przewagi w handlu RTA jako najbardziej adekwatnego do oceny analizowanego zjawiska, oraz syntetyczną charakterystyką poziomu i struktury towarowej handlu zagranicznego produktami rolno-spożywczymi Polski z wybranymi partnerami handlowymi.

\subsection{Uwagi metodyczne}

Wskaźnik ujawnionej przewagi komparatywnej B. Balassy (RCA - revealed comparative advantage) należy do grupy wskaźników konkurencyjności ex post, tj. odnosi się do pomiaru konkurencyjności w przeszłości ${ }^{117}$. Badanie ujawnionych przewag komparatywnych według B. Balassy polega bowiem na ustaleniu, czy udział danego produktu w eksporcie danego kraju jest wyższy (niższy) od udziału tego produktu w światowym eksporcie na określony rynek. Szerokie zastosowanie tego wskaźnika jako miernika konkurencyjności wynika z jego prostej formuły, która w sposób naturalny daje odpowiedź na pytanie,

\footnotetext{
${ }^{114}$ Ibid., s. 165.

${ }^{115}$ J. Misala, Międzynarodowa zdolność konkurencyjna i międzynarodowa konkurencyjność gospodarki narodowej, Politechnika Radomska, Radom 2007, s. 32.

${ }^{116}$ E. Siggel, International Competitiveness and Comparative Advantage: A Survey and a Proposal for Measurement, „Journal of Industry, Competitiveness and Trade” 2006, nr 6.

${ }^{117}$ J. Misala, Międzynarodowa konkurencyjność..., op. cit., s. 135.
} 
w jakich grupach towarowych dany kraj posiada przewagi komparatywne ${ }^{118}$. Ponadto zwraca się w literaturze uwagę na niewielką wrażliwość formuły tego wskaźnika na różnice w fazach cyklu gospodarczego między poszczególnymi krajami ${ }^{119}$.

Wskaźnik ujawnionych przewag komparatywnych w eksporcie według B. Balassy określa następująca formuła ${ }^{120}$ :

$$
R C A_{i k}=\frac{X_{i k}}{\sum_{i=1}^{N} X_{i k}}: \frac{X_{i w}}{\sum_{i=1}^{N} X_{i w}}
$$

gdzie:

$R C A_{i k}$ - wskaźnik ujawnionych przewag komparatywnych w eksporcie grupy produktów $i$ przez kraj $k$ na określonym rynku,

$X_{i k} \quad$ - eksport grupy produktów $i$ przez kraj $k$ na określony rynek,

$X_{i w} \quad$ - eksport grupy produktów $i$ przez grupę krajów $w$ na określony rynek,

$N \quad$ - liczba grup produktów.

Wskaźnik RCA przybiera wartości od zera do nieskończoności, przy czym wyróżnia się dwa przedziały o odmiennych interpretacjach. Gdy wskaźnik ten przyjmuje wartości większe od 1 (udział danej grupy towarów w eksporcie omawianego kraju jest wyższy od odpowiedniego udziału w światowym eksporcie), badany kraj posiada ujawnione przewagi komparatywne w eksporcie na określony rynek. W przeciwnym razie, gdy wskaźnik przyjmuje wartości mniejsze od 1 (udział danej grupy towarów w eksporcie omawianego kraju jest niższy niż udział tej grupy towarów w eksporcie światowym), badany kraj nie posiada ujawnionych przewag komparatywnych w eksporcie na określony rynek. O posiadaniu czy braku ujawnionych przewag komparatywnych będzie zatem decydować to, czy udział danego produktu w eksporcie analizowanego kraju na wybrany rynek jest wyższy czy niższy niż odpowiedni udział tego produktu w eksporcie wszystkich państw świata na ten rynek.

Formuła zaproponowana przez B. Balassę została w kolejnych latach zmodyfikowana m.in. przez T.L. Vollratha, co pozwoliło na wyeliminowanie podwójnego liczenia analizowanych krajów i branż. Zmodyfikowany indeks T.L. Vollratha

\footnotetext{
${ }^{118}$ Ł. Ambroziak, I. Szczepaniak, Monitoring i ocena konkurencyjności polskich producentów żywności (4). Pozycja konkurencyjna, seria „Program Wieloletni 2011-2014”, nr 74, IERiGŻ-PIB, Warszawa 2013, s. 44-45.

${ }^{119}$ J.C. Hartigan, The U.S. tariff and comparative advantage: A survey of method, „Weltwirtschaftliches Archiv" 1981, vol. 117(1), s. 65-109.

${ }^{120}$ B. Balassa, Trade Liberalization..., op. cit., 99-123.
} 
nazywany jest wskaźnikiem relatywnej przewagi eksportu (RXA - relative export advantage) i definiowany jest następująco ${ }^{121}$ :

gdzie:

$$
R X A_{i k}=\frac{\frac{X_{i k}}{X_{i}}}{\frac{X_{c k}}{X_{c}}}
$$

$R X A_{i k}$ - wskaźnik relatywnej przewagi eksportu grupy produktów $i$ kraju $k$,

$X_{i k} \quad$ - eksport grupy produktów $i$ przez kraj $k$ na określony rynek,

$X_{i} \quad$ - eksport grupy produktów $i$ analizowanej grupy krajów z wyjątkiem kraju $k$ na określony rynek,

$X_{c k} \quad-$ całkowity eksport produktów z kraju $k \mathrm{z}$ wyjątkiem grupy produktów $i$ na określony rynek,

$X_{c} \quad$ - całkowity eksport produktów ze wszystkich analizowanych krajów z wyjątkiem kraju $k$ i z wyjątkiem grupy produktów $i$ na określony rynek.

Gdy wskaźnik ten przyjmuje wartości większe od 1, oznacza to, że badany kraj posiada względem analizowanego rynku ujawnione przewagi komparatywne w handlu daną grupą produktów, podczas gdy wartości poniżej 1 wskazują, że kraj ten nie posiada takich przewag.

Oprócz ww. wskaźnika T.L. Vollrath zaproponował, podobny w konstrukcji, indeks relatywnej przewagi importu (RMA - relative import advantage), którego formuła jest następująca ${ }^{122}$ :

$$
R M A_{i k}=\frac{\frac{M_{i k}}{M_{i}}}{\frac{M_{c k}}{M_{c}}}
$$

gdzie:

$R M A_{i k}-$ wskaźnik relatywnej przewagi importu grupy produktów $i$ kraju $k$,

$M_{i k} \quad$ - import grupy produktów $i$ przez kraj $k$ z określonego rynku,

$M_{i} \quad-$ import grupy produktów $i$ analizowanej grupy krajów z wyjątkiem kraju $k$ z określonego rynku,

$M_{c k} \quad$ - całkowity import produktów z kraju $k \mathrm{z}$ wyjątkiem grupy produktów $i$ $\mathrm{z}$ określonego rynku,

${ }^{121}$ T.L. Vollrath, A theoretical evaluation of alternative trade intensity measures of revealed comparative advantage, „Weltwirtschaftliches Archiv” 1991, nr 130, s. 265-279.

${ }^{122}$ Ibid. 
$M_{c} \quad$ - całkowity import produktów z wszystkich analizowanych krajów z wyjątkiem kraju $k \mathrm{i}$ z wyjątkiem grupy produktów $i \mathrm{z}$ określonego rynku.

Wskaźnik RMA interpretuje się odwrotnie niż RXA. Wartości tego miernika powyżej 1 świadczą o braku przewag komparatywnych danego kraju w handlu daną grupą produktów. Kraj posiada natomiast takie przewagi, jeśli wskaźnik RMA przyjmuje wartości poniżej 1.

Odejmując od wskaźnika relatywnej przewagi eksportu (RXA) wskaźnik relatywnej przewagi importu (RMA), można otrzymać kolejny wskaźnik, tzw. wskaźnik ujawnionej konkurencyjności ( $\mathrm{RC}$ - revealed competitiveness), którego formułę L. Latruffe ${ }^{123}$ sformułował następująco:

$$
R C_{i k}=\ln R X A_{i k}-\ln R M A_{i k}
$$

gdzie:

$R C_{i k} \quad$-wskaźnik ujawnionej konkurencyjności grupy produktów $i$ w handlu kraju $k$.

Zastosowanie $\mathrm{w}$ tej formule postaci logarytmicznej pozwala na zachowanie symetryczności dodatnich i ujemnych wskaźników RC w przedziale wahającym się wokół zera ${ }^{124}$. Wskaźnik RC większy od 0 oznacza występowanie ujawnionych przewag komparatywnych w handlu daną grupą produktów, zaś jego wartość mniejsza od 0 wskazuje, że przewagi takie nie występują. Wyższość indeksu RC nad wcześniej omówionymi wskaźnikami ujawnionych przewag komparatywnych wynika $\mathrm{z}$ jednoczesnego uwzględnienia sytuacji w zakresie eksportu i importu produktów danego kraju.

W zbliżony sposób do oceny ujawnionych przewag komparatywnych podeszli J.H.M. Wijnands i D. Verhoog, autorzy Raportu pt. Competitiveness of the EU food industry. Ex-post assessment of trade performance embedded in international economic theory ${ }^{125}$. Zbudowali oni syntetyczny wskaźnik konkurencyjności, którego jednym ze wskaźników cząstkowych był wskaźnik ujawnionych przewag w handlu (RTA - relative trade advantage). Zdefiniowali go jako różnicę pomiędzy wskaźnikiem ujawnionych przewag w eksporcie (RXA) a wskaźnikiem ujawnionych przewag w imporcie (RMA) ${ }^{126}$ :

$$
R T A_{i c t}=R X A_{i c t}-R M A_{i c t}
$$

\footnotetext{
${ }^{123}$ L. Latruffe, Competitiveness..., s. 7-8.

${ }^{124}$ Ibid., s. 8; J. Misala, Międzynarodowa konkurencyjność..., op. cit., s. 165.

${ }^{125}$ J.H.M. Wijnands, D. Verhoog, Competitiveness of the EU food industry. Ex-post assessment of trade performance embedded in international economic theory, LEI Wageningen UR, February 2016.

${ }^{126}$ Ibid., s. 16.
} 


$$
R X A_{i c t}=\frac{\frac{X_{i c t}}{X_{i w t}}}{\frac{X T_{c t}}{X T_{w t}}} \quad R M A_{i c t}=\frac{\frac{M_{i c t}}{M_{i w t}}}{\frac{M T_{c t}}{M T_{w t}}}
$$

gdzie:

$R T A_{i c t}$ - wskaźnik ujawnionych przewag w handlu produktami przemysłu $i$, kraju $c$, w okresie $t$,

$R X A_{\text {ict }}$ - wskaźnik ujawnionych przewag w eksporcie produktów przemysłu $i$, kraju $c$, w okresie $t$,

$R M A_{i c t}$ - wskaźnik ujawnionych przewag w imporcie produktów przemysłu $i$, kraju $c$, w okresie $t$,

$X_{i c t}-$ wartość eksportu produktów przemysłu $i$, kraju $c$, w okresie $t$,

$X_{i w t} \quad$ - wartość światowego eksportu produktów przemysłu $i$, w okresie $t$,

$X T_{c t}$ - wartość eksportu produktów całego przemysłu przetwórczego, kraju $c$, w okresie $t$,

$X T_{w t}$ - wartość światowego eksport produktów przemysłu przetwórczego, w okresie $t$,

$M_{i c t} \quad$-wartość importu produktów przemysłu $i, \operatorname{kraju} c$, w okresie $t$,

$M_{i w t} \quad$-wartość światowego importu produktów przemysłu $i$, w okresie $t$,

$M T_{c t} \quad$ - wartość importu produktów całego przemysłu przetwórczego, kraju $c$, w okresie $t$,

$M T_{w t} \quad$ - wartość światowego importu produktów całego przemysłu przetwórczego, w okresie $t$.

W tym ujęciu dodatni wskaźnik RTA również wskazuje na przewagi komparatywne danego kraju w handlu produktami danej branży przemysłu: najogólniej rzecz biorąc, eksport przewyższa bowiem wtedy import. Wartości ujemne oznaczają natomiast brak przewag komparatywnych. Autorzy Raportu podkreślają, że wskaźnik ten wykorzystywany jest w celu dokonania bardziej pogłębionej oceny pozycji konkurencyjnej danego kraju w handlu poszczególnymi grupami produktów ${ }^{127}$.

\footnotetext{
${ }^{127}$ Szczegółowa analiza metodologii oceny pozycji konkurencyjnej przemysłu spożywczego w UE (w tym ujawnionych przewag komparatywnych), zastosowanej w Raporcie LEI Wageningen UR - Competitiveness of the EU food industry. Ex-post assessment of trade performance embedded in international economic theory, oraz jej wyników została przedstawiona w: M. Tereszczuk, Ocena pozycji konkurencyjnej przemystu spożywczego w Polsce na tle wybranych państw Unii Europejskiej, [w:] I. Szczepaniak (red.), Konkurencyjność polskich producentów żywności i jej determinanty (2), seria „Monografie Programu Wieloletniego 2015-2019”, nr 38, IERiGŻ-PIB, Warszawa 2016, s. 93-121.
} 
W metodologii zastosowanej przez J.H.M. Wijnandsa i D. Verhooga zwracają uwagę pewne niewielkie uproszczenia w stosunku do rozwiązań proponowanych przez T.L. Vollratha oraz L. Latruffe'a. W przypadku wskaźników ujawnionych przewag w eksporcie (RXA) oraz w imporcie (RMA) polegają one na nieeliminowaniu z liczenia analizowanych krajów i branż, co ma jednak minimalny wpływ na otrzymane wyniki ${ }^{128}$. Druga różnica dotyczy niezastosowania w rachunku wskaźnika ujawnionych przewag w handlu (RTA) postaci logarytmicznej, a zatem niezapewnienie symetryczności dodatnich i ujemnych wskazań tego miernika (co już jest cechą częściej krytykowaną).

Biorąc pod uwagę powyższe rozważania, do oceny przewag komparatywnych w polskim handlu produktami rolno-spożywczymi na wybranych rynkach zdecydowano się wykorzystać wskaźnik relatywnej przewagi handlowej (RTA) w postaci logarytmicznej oraz wskaźniki ujawnionych przewag w eksporcie (RXA) i w imporcie (RMA), w których formułach zrezygnowano jednak z eliminowania Polski i analizowanych grup produktów ${ }^{129}$. W obliczeniach zastosowano następujące wzory:

$$
\begin{gathered}
R T A_{i P L}=\ln R X A_{i P L}-\ln R M A_{i P L} \\
R X A_{i P L}=\frac{\frac{X_{i P L}}{X_{i w}}}{\frac{X_{P L}}{X_{w}}} \quad R M A_{i P L}=\frac{\frac{M_{i P L}}{M_{i w}}}{\frac{M_{P L}}{M_{w}}}
\end{gathered}
$$

gdzie:

$R T A_{i P L}$ - wskaźnik relatywnej przewagi w polskim handlu grupą produktów $i$ na danym rynku,

$R X A_{i P L}$ - wskaźnik relatywnej komparatywnej przewagi polskiego eksportu grupy produktów $i$ na dany rynek,

$R M A_{i P L}$ - wskaźnik relatywnej komparatywnej przewagi polskiego importu grupy produktów $i$ z danego rynku,

\footnotetext{
${ }^{128} \mathrm{~W}$ takiej sytuacji wskaźnik RXA po przekształceniu jest tożsamy z RCA. O sytuacji takiej pisze m.in. L. Latruffe, Competitiveness..., op. cit., s. 8.

${ }^{129}$ Za nieeliminowaniem Polski oraz analizowanych grup produktów z formuł określających wskaźniki ujawnionych przewag w eksporcie (RXA) i w imporcie (RMA) przemawiają dwa czynniki. Po pierwsze, różnice w otrzymywanych wynikach obliczeń, jak sprawdzono, są minimalne. Po drugie, w prowadzonych od lat badaniach konkurencyjności polskich producentów żywności niejednokrotnie wykorzystywano wskaźniki RCA (m.in. Ł. Ambroziak, I. Szczepaniak, Wskaźnikowa ocena konkurencyjności handlu produktami rolno-spożywczymi, [w:] I. Szczepaniak (red.), Monitoring i ocena konkurencyjności polskich producentów żywności (1), seria „Program Wieloletni 2011-2014”, nr 25, IERiGŻ-PIB, Warszawa 2011, s. 45-65; Ł. Ambroziak, I. Szczepaniak, Monitoring i ocena ..., op. cit., s. 50-57), również nie eliminując ani Polski, ani analizowanych grup produktów. Chcąc umożliwić porównywalność wyników i zachować spójność metodologiczną, zdecydowano się kontynuować tę metodę.
} 
$X_{i P L}-$ polski eksport grupy produktów $i$ na dany rynek,

$X_{i w}$ - światowy eksport grupy produktów $i$ na dany rynek,

$X_{P L} \quad$ - polski eksport wszystkich grup produktów na dany rynek,

$X_{w} \quad$ - światowy eksport wszystkich grup produktów na dany rynek,

$M_{i P L}$ - polski import grupy produktów $i$ z danego rynku,

$M_{i w}$ - światowy import grupy produktów $i$ z danego rynku,

$M_{P L} \quad$ - polski import wszystkich grup produktów z danego rynku,

$M_{w} \quad$ - światowy import wszystkich grup produktów z danego rynku.

Dodatnia wartość wskaźnika RTA (większa od 0) oznacza występowanie ujawnionej przewagi komparatywnej w polskim handlu daną grupą produktów na danym rynku i wskazuje na intensywność tej przewagi, natomiast ujemna jego wartość (mniejsza od 0) wskazuje, że przewaga ta nie występuje. Wskaźnik ten $\mathrm{w}$ porównaniu $\mathrm{z}$ dotychczas wykorzystywanym $\mathrm{w}$ badaniach konkurencyjności polskich producentów żywności wskaźnikiem ujawnionych przewag komparatywnych RCA ma bardziej kompleksowy charakter, gdyż uwzględnia jednocześnie sytuację eksportową i importową kraju.

W niniejszej analizie wyznaczono wskaźniki RTA (a wcześniej także RXA i RMA) w polskim handlu produktami rolno-spożywczymi na rynku światowym, rynku państw UE-15 i UE-13 oraz rynku krajów spoza UE. Okres objęty badaniem obejmuje lata 2004-2016. Źródłem danych była baza danych handlowych WITS-Comtrade, w której strumienie handlu wyrażone są w USD. Analizę przeprowadzono na poziomie działów HS. Pod pojęciem ,produkty rolno-spożywcze” rozumiane są działy 01-24 Zharmonizowanego Systemu Oznaczania i Kodowania Towarów (HS).

\subsection{Wyniki handlu zagranicznego produktami rolno-spożywczymi Polski na wybranych rynkach}

\subsubsection{Tendencje ogólne}

Lata 2004-2016 to okres systematycznego wzrostu i poprawy wyników handlu zagranicznego produktami rolno-spożywczymi (wykres 2.1). Pozytywne zmiany widoczne były już w roku akcesji, kiedy to obroty handlowe Polski produktami rolno-spożywczymi były o blisko 30\% większe niż w 2003 roku. Obroty te, dzięki utrzymującemu się wzrostowi wartości zarówno eksportu, jak i importu, zwiększały się także w kolejnych latach. Wyjątek stanowił jedynie rok 2009, gdy wartość obrotów zmalała o prawie $11 \% \mathrm{w}$ porównaniu z rokiem poprzednim. Zmiany te wynikały ze spowolnienia gospodarczego wywołanego przez światowy kryzys finansowy. W 2016 roku łączna wartość obrotów handlowych Polski 
produktami rolno-spożywczymi wyniosła ponad 43,2 mld USD, w tym eksport osiągnął poziom 25,5 mld USD, a import 17,7 mld USD. W porównaniu z 2004 rokiem oznacza to ponad trzyipółkrotny wzrost obrotów handlowych, w tym samego eksportu - czterokrotny, a importu - przeszło trzykrotny ${ }^{130}$. Od momentu akcesji Polski do UE dodatnie saldo wymiany handlowej produktami rolno-spożywczymi także na ogół się zwiększało (z wyjątkiem lat 2008 i 2011). W 2016 roku wartość salda obrotów przekroczyła 7,8 mld USD, co oznacza, że była wprawdzie o $8,3 \%$ niższa niż przed rokiem, ale ponad siedmioipółkrotnie wyższa w porównaniu z 2004 rokiem. Dla porównania, w tym samym okresie skumulowany wskaźnik wzrostu PKB, wyrażonego w cenach stałych, wyniósł około $156 \%{ }^{131}$. Dynamika wzrostu eksportu i salda handlu zagranicznego produktami rolno-spożywczymi znacznie przewyższa więc dynamikę PKB, potwierdzając proeksportowy charakter rozwoju tego sektora gospodarki w Polsce.

Wykres 2.1. Handel rolno-spożywczy Polski w latach 2004-2016 (w mln USD)

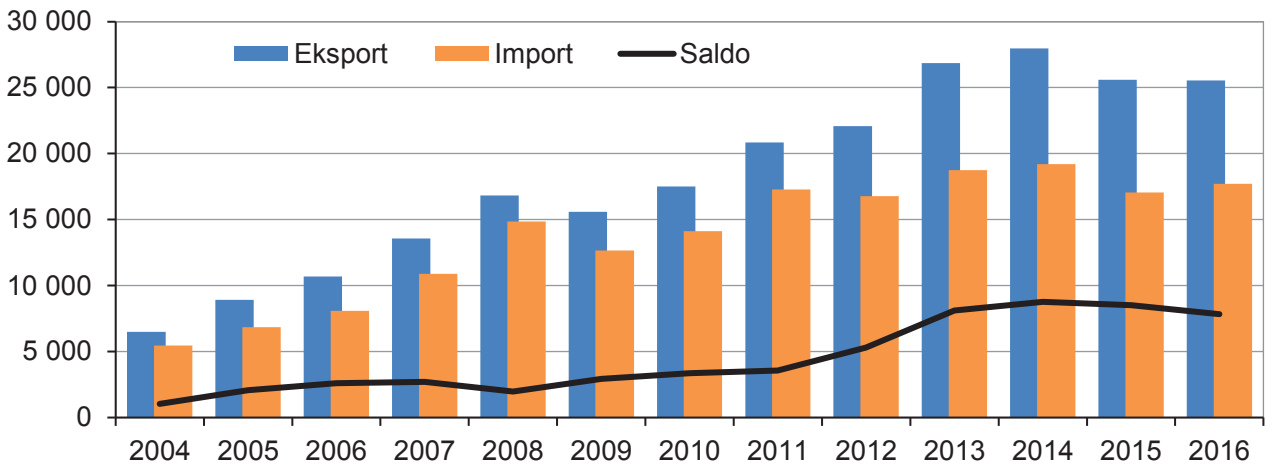

Źródto: opracowanie wtasne na podstawie danych WITS-Comtrade.

W latach 2004-2016 w strukturze geograficznej polskiego eksportu rolno-spożywczego dominowały państwa członkowskie Unii Europejskiej, choć ich znaczenie w poszczególnych latach zmieniało się (wykres 2.2). Do 2008 roku notowano stopniowy wzrost ich udziału, w latach 2009-2012 spadek, a w kolejnych trzech latach ponownie wzrost. W 2016 roku udział państw UE w polskim eksporcie rolno-spożywczym wyniósł $80,4 \%$. Był to udział o 5,9 pkt proc. wyższy niż w 2004 roku i podobny do odnotowanego w 2009 roku (80,8\%). W grupie państw członkowskich dominującym partnerem handlowym były państwa UE-15,

\footnotetext{
${ }^{130}$ W latach 2015-2016 nastąpił spadek obrotów handlowych zarówno Polski ogółem, jak i sektora rolno-spożywczego wyrażonych w USD, co wynikało ze znacznego osłabienia złotego i euro w stosunku do dolara amerykańskiego. Dane dotyczące polskiego handlu zagranicznego pochodzące z Ministerstwa Finansów, wyrażone w euro, nie potwierdzają tego spadku.

${ }^{131}$ Baza danych GUS: https://stat.gov.pl/wskazniki-makroekonomiczne/ (dostęp: 30.10.2017).
} 
z udziałem sięgającym na ogół 58-59\%. Najwyższy był on w 2015 roku, gdy wyniósł blisko 61\%, natomiast najniższy - w roku akcesji (57\%). W 2016 roku udział państw UE-15 w polskim eksporcie rolno-spożywczym sięgnął blisko $60 \%$. Udział państw UE-13 w eksporcie rolno-spożywczym Polski przez większość analizowanego okresu oscylował wokół $20 \%$. Jego najwyższy poziom odnotowano w 2008 roku (23\%), a najniższy - w roku akcesji (17,5\%). W 2016 roku sięgnął on blisko $21 \%$. Wahania udziału nowych państw członkowskich w eksporcie rolno-spożywczym Polski były znacznie większe niż w przypadku państw „Piętnastki”.

Wykres 2.2. Struktura geograficzna eksportu i importu rolno-spożywczego Polski (w proc.)

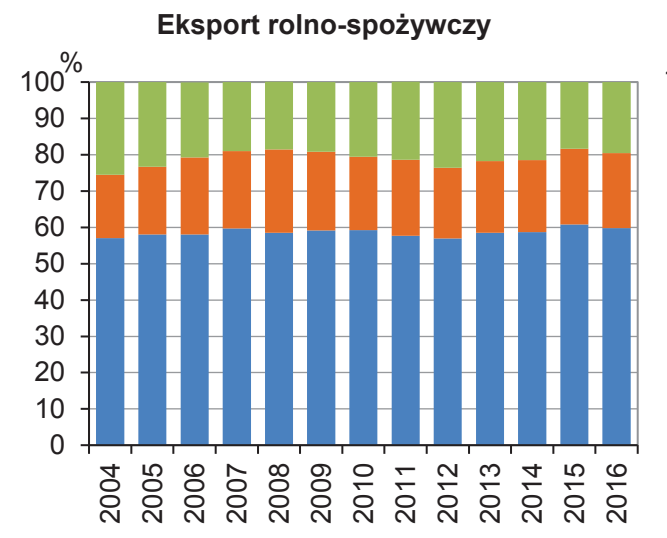

-UE-15 -UE-13 -poza UE

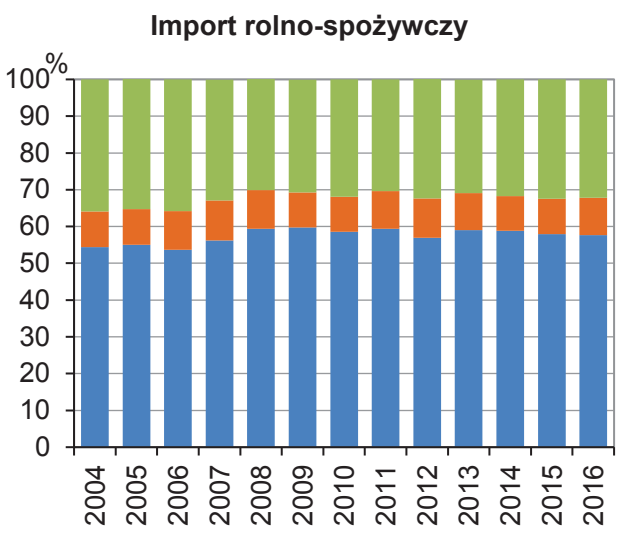

-UE-15 -UE-13 -spoza UE

Źródto: opracowanie wtasne na podstawie danych WITS-Comtrade.

W strukturze geograficznej polskiego importu rolno-spożywczego, podobnie jak eksportu, również przeważały państwa członkowskie UE (wykres 2.2). W latach 2004-2016 ich udział wahał się w granicach 63-70\%. Najwyższy był w 2008 roku, ale generalnie w całym analizowanym okresie wykazywał niewielką tendencję wzrostową. Zwiększenie udziału UE w polskim imporcie rolno-spożywczym wynikało przede wszystkim ze wzrostu znaczenia państw UE-15. Do 2007 roku ich udział w imporcie rolno-spożywczym wahał się w granicach 52-56\%, a przez większość następnego okresu sięgał około 59-60\%. W 2016 roku wyniósł on 57,7\%, a więc o 3,3 pkt proc. więcej niż w roku akcesji. Udział państw UE-13 w polskim imporcie rolno-spożywczym nie uległ w analizowanym okresie dużym zmianom - wahał się w granicach 9,5-11\%. Łącznie w latach 2004-2016 zwiększył się on o 0,4 pkt proc., do 10,1\%. Znaczenie państw członkowskich w imporcie rolno-spożywczym było zatem wyraźnie mniejsze niż w eksporcie rolno-spożywczym Polski. 
W latach 2004-2016 w polskim handlu zagranicznym produktami rolno-spożywczymi z państwami UE następowała systematyczna poprawa salda (wykres 2.3). W 2016 roku saldo to osiągnęło wartość 8,5 mld USD. Świadczy to wyraźnie o tym, że polscy producenci żywności są w dalszym ciągu konkurencyjni na rynku unijnym. O ile jednak do 2007 roku saldo to było przede wszystkim generowane przez wymianę z państwami UE-15, o tyle w latach 2008-2011 jego źródłem był głównie handel z nowymi państwami członkowskimi. Członkostwo w UE nadało bowiem nowy, bardzo silny impuls wymianie handlowej polskimi produktami rolno-spożywczymi z tymi krajami. Począwszy od 2012 roku relacja ta uległa odwróceniu i na skutek dynamicznego wzrostu salda obrotów z krajami „Piętnastki” (do 5,7 mld USD w 2015 roku i 5,1 mld USD w 2016 roku), saldo to ponownie ma decydujący udział w generowanej przez sektor nadwyżce.

Wykres 2.3. Saldo handlu rolno-spożywczego Polski z UE, z krajami spoza UE oraz ogółem (w mld USD)

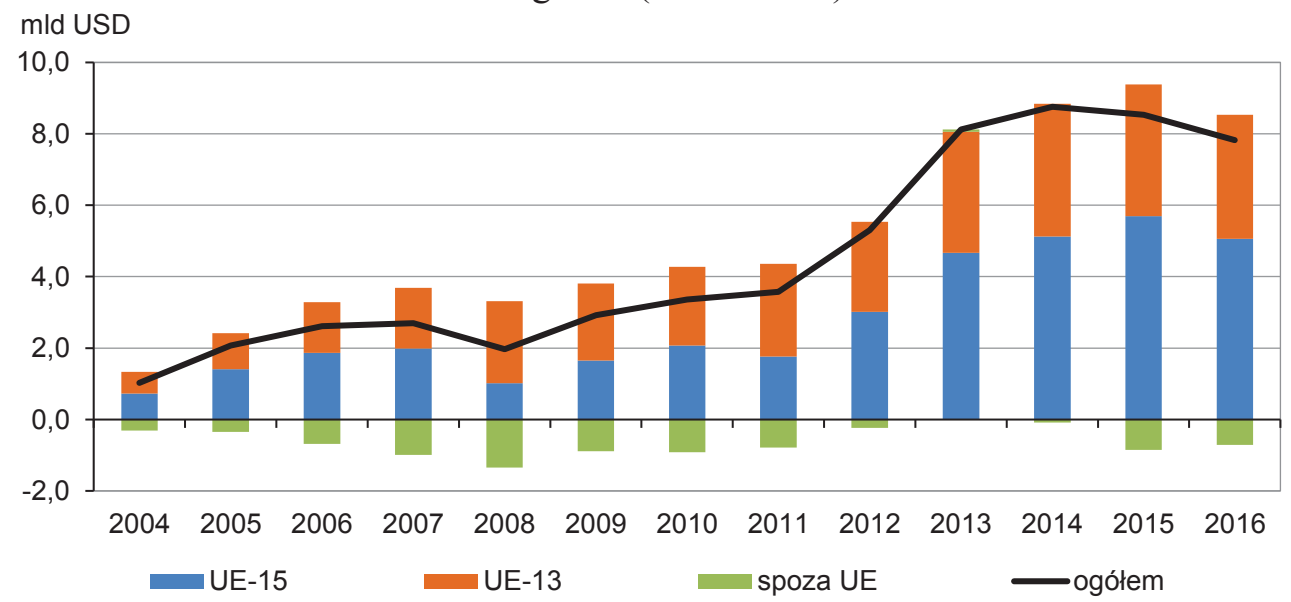

Źródło: opracowanie własne na podstawie danych WITS-Comtrade.

Odmienna sytuacja występuje w obrotach handlowych z krajami spoza UE. W latach 2004-2008 ujemne saldo obrotów handlowych produktami rolno-spożywczymi z tymi krajami systematycznie się pogłębiało - aż do 1,3 mld USD. W kolejnych latach bilans obrotów handlowych z krajami trzecimi poprawiał się, co zaowocowało osiągnięciem w 2013 roku niewielkiej nadwyżki (0,07 mld USD). Lata 2014-2016 ponownie jednak zamknęły się deficytem (w 2016 roku w wysokości 0,71 mld USD). Dodatnie saldo handlu zagranicznego z państwami członkowskimi Unii Europejskiej z nadwyżką pokrywa jednak deficyt w wymianie handlowej z krajami spoza UE i w efekcie polski sektor rolno-spożywczy niezmiennie osiąga dodatni bilans handlowy. 


\subsubsection{Handel rolno-spożywczy Polski ogólem - ujęcie towarowe}

W 2016 roku do najważniejszych grup towarowych (działów HS) w eksporcie rolno-spożywczym Polski ogółem należały: mięso i podroby (02), tytoń i wyroby tytoniowe (24), przetwory zbożowe i pieczywo cukiernicze (19), produkty mleczarskie (04), kakao i przetwory z kakao (18), różne przetwory spożywcze (21), przetwory z mięsa i ryb (16), ryby i owoce morza (03), przetwory z owoców i warzyw (20) oraz zboża (10). Na tych dziesięć grup produktów przypadało 74,1\% polskiego eksportu rolno-spożywczego (tabela 2.1 ). W latach 2004-2016 zwiększyła się wartość eksportu niemal wszystkich grup produktów rolno-spożywczych. W dwunastu działach HS odnotowano wzrost wyższy od przeciętnego, najwyższy w przypadku: zbóż, tytoniu i wyrobów tytoniowych, tłuszczów i olejów oraz kawy, herbaty i przypraw. W efekcie tych zmian zaszło wyraźne przetasowanie na liście dziesięciu głównych grup towarowych - zniknęły z niej warzywa, owoce i orzechy oraz cukry i wyroby cukiernicze, a pojawiły się zboża, przetwory z mięsa i ryb oraz tytoń i wyroby tytoniowe. Nieznacznie obniżył się także stopień koncentracji polskiego eksportu rolno-spożywczego na rynek światowy, gdyż w 2004 roku na dziesięć głównych grup towarowych przypadało $74,6 \%$ tego eksportu.

Do najważniejszych grup towarowych (działów HS) w imporcie rolno-spożywczym Polski ogółem w 2016 roku należały: ryby i owoce morza (03), mięso i podroby (02), owoce i orzechy (08), odpady i pasze dla zwierząt (23), kakao i przetwory z kakao (18), różne przetwory spożywcze (21), produkty mleczarskie (04), tłuszcze i oleje (15), napoje (22) oraz tytoń i wyroby tytoniowe (24). Udział tych dziesięciu grup produktów w polskim imporcie rolno-spożywczym wynosił 67,7\% (tabela 2.1). W latach 2004-2016 zwiększyła się wartość importu wszystkich grup produktów rolno-spożywczych. W trzynastu działach HS odnotowano wzrost wyższy od przeciętnego, najwyższy w następujących grupach produktów: tłuszcze i oleje, produkty mleczarskie oraz zwierzęta żywe. W efekcie zaszły zmiany na liście dziesięciu głównych grup towarowych - zniknęły z niej kawa, herbata i przyprawy oraz zboża, a pojawiły się produkty mleczarskie oraz tytoń i wyroby tytoniowe. Na zbliżonym poziomie utrzymał się stopień koncentracji polskiego importu rolno-spożywczego ogółem, gdyż w 2004 roku na dziesięć głównych grup towarowych przypadało $67,9 \%$ tego importu.

Saldo obrotów handlowych produktami rolno-spożywczymi Polski ogółem w 2016 roku dodatnie było w przypadku 14 działów HS (w 2004 roku - 10 działów). Najwyższa jego wartość dotyczyła handlu mięsem i podrobami, przetworami zbożowymi i pieczywem cukierniczym, tytoniem i wyrobami tytoniowymi oraz przetworami z mięsa i ryb. Największy deficyt generowała wymiana handlowa odpadami i paszami dla zwierząt oraz rybami i owocami morza. 


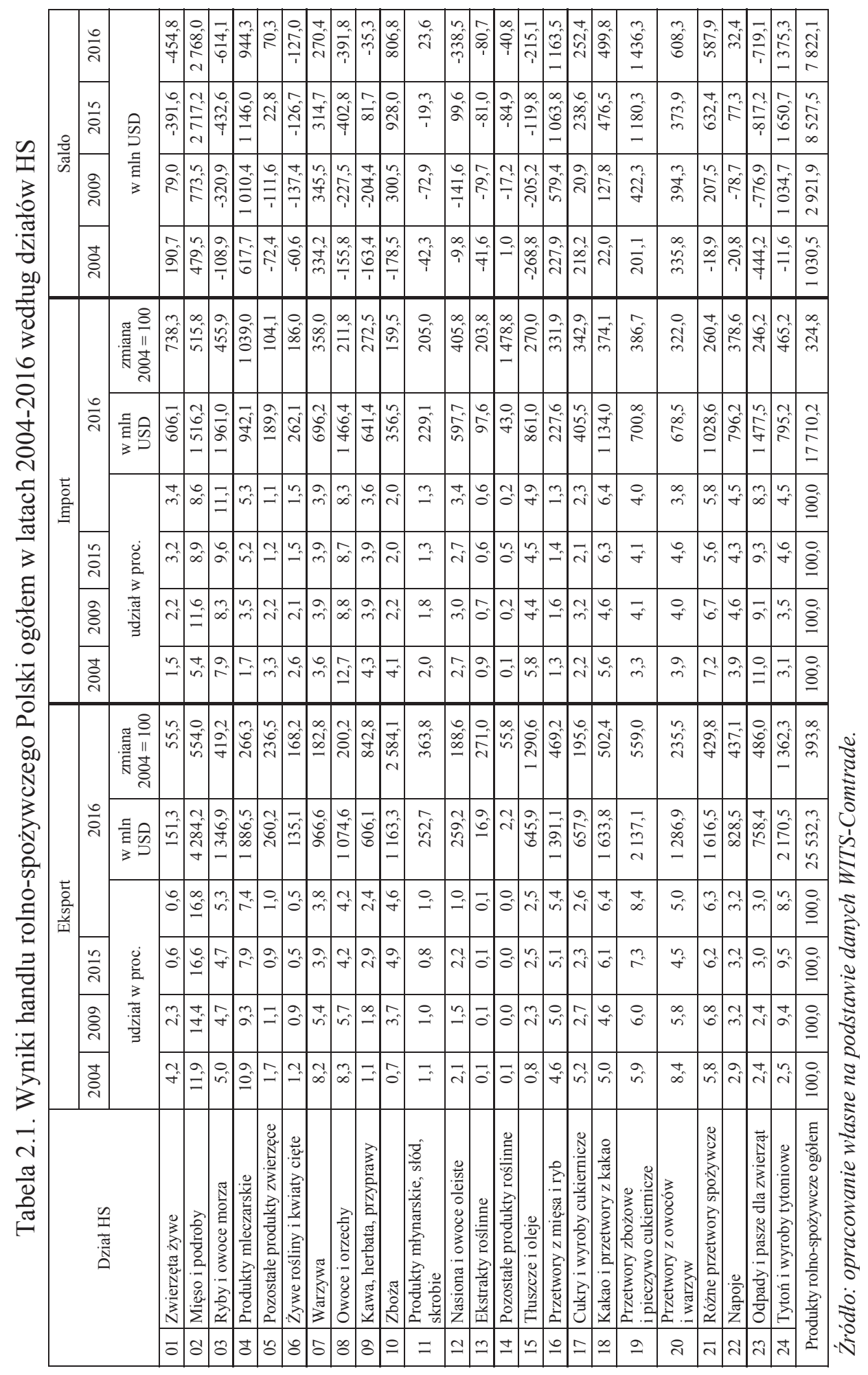




\subsubsection{Handel rolno-spożywczy Polski z państwami UE-15 - ujęcie towarowe}

W latach 2004-2016 w eksporcie rolno-spożywczym Polski do państw UE-15 wzrosła wartość eksportu większości grup towarowych. W trzynastu działach HS odnotowano wzrost wyższy od przeciętnego, największy w przypadku: tytoniu i wyrobów tytoniowych, zbóż oraz kawy, herbaty i przypraw. Na liście dziesięciu głównych grup towarowych także zaszły w tym okresie wyraźne zmiany (tabela 2.2). Zniknęły z niej zwierzęta żywe, owoce i orzechy oraz cukry i wyroby cukiernicze, pojawiło się natomiast kakao i przetwory z kakao (18), różne przetwory spożywcze (21) oraz tytoń i wyroby tytoniowe (24). Do pozostałych grup towarowych obecnych na liście „top 10" w 2016 roku należały: mięso i podroby (02), przetwory zbożowe i pieczywo cukiernicze (19), ryby i owoce morza (03), przetwory z mięsa i ryb (16), produkty mleczarskie (04), przetwory z owoców i warzyw (20) oraz warzywa (10). W efekcie tych zmian, w latach 2004-2016 zmniejszył się nieco stopień koncentracji towarowej polskiego eksportu rolno-spożywczego do państw UE-15. Na dziesięć głównych grup towarowych w 2016 roku przypadało 77,9\% tego eksportu, czyli o 1,4 pkt proc. mniej niż w 2004 roku (79,3\%).

W analizowanym okresie w imporcie rolno-spożywczym Polski z państw UE-15 wzrosła wartość importu wszystkich grup towarowych. W jedenastu działach HS wzrost ten był wyższy od przeciętnego. Lista dziesięciu głównych grup towarowych $\mathrm{w}$ polskim imporcie rolno-spożywczym z UE-15 również uległa w tym okresie zmianom (tabela 2.2). Z grupy tej wypadły żywe rośliny i kwiaty cięte oraz odpady i pasze dla zwierząt, a pojawiły się zwierzęta żywe (01) oraz produkty mleczarskie (04), a więc tradycyjne polskie produkty eksportowe. Do pozostałych grup towarowych obecnych na liście „top 10” w 2016 roku należały: mięso i podroby (02), kakao i przetwory z kakao (18), owoce i orzechy (08), różne przetwory spożywcze (21), thuszcze i oleje (15), przetwory zbożowe i pieczywo cukiernicze (19), warzywa (10) oraz napoje (22). Zmiany te skutkowały zmniejszeniem się w latach 2004-2016 stopnia koncentracji towarowej polskiego importu rolno-spożywczego z UE-15, nieco większym przy tym niż eksportu. W 2016 roku na dziesięć głównych działów HS przypadało 70,4\% tego importu, a więc o 1,7 pkt proc. mniej niż w roku akcesji $(72,1 \%)$.

W 2016 roku nadwyżka w obrotach handlowych produktami rolno-spożywczymi Polski z państwami „Piętnastki” wystąpiła w przypadku 16 działów HS (w 2004 roku - 12 działów), najwyższa jej wartość dotyczyła handlu mięsem i podrobami, tytoniem i wyrobami tytoniowymi, przetworami z mięsa i ryb, rybami i owocami morza oraz przetworami zbożowymi i pieczywem cukierniczym. Źródłem największego deficytu była wymiana handlowa tłuszczami i olejami oraz zwierzętami żywymi. 


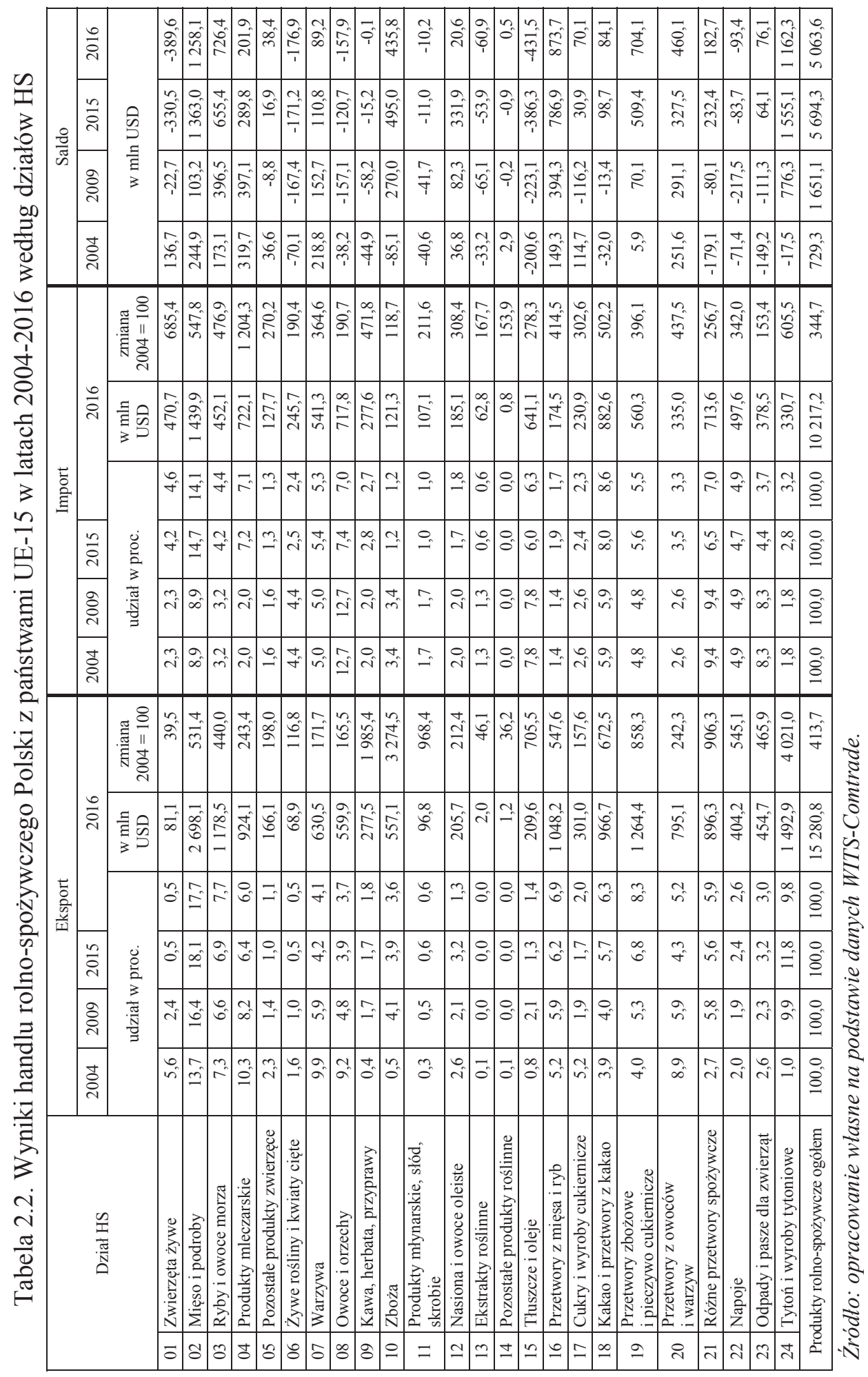




\subsubsection{Handel rolno-spożywczy Polski z państwami UE-13 - ujęcie towarowe}

W latach 2004-2016 w eksporcie rolno-spożywczym Polski do państw UE-13 wzrosła wartość eksportu wszystkich grup towarowych. W jedenastu działach HS odnotowano wzrost wyższy od przeciętnego, największy jeśli chodzi o thuszcze i oleje, tytoń i wyroby tytoniowe oraz mięso i podroby. Na liście dziesięciu głównych grup towarowych także zaszły w tym okresie wyraźne zmiany (tabela 2.3). Nie występują na niej już warzywa, owoce i orzechy, cukry i wyroby cukiernicze oraz przetwory z owoców i warzyw. W ich miejsce weszły natomiast: kawa, herbata i przyprawy (09), tłuszcze i oleje (15), przetwory z mięsa i ryb (16) oraz tytoń i wyroby tytoniowe (24). Do pozostałych grup towarowych obecnych na liście „top 10” w 2016 roku należały: mięso i podroby (02), produkty mleczarskie (04), przetwory zbożowe i pieczywo cukiernicze (19), różne przetwory spożywcze (21), kakao i przetwory z kakao (18) oraz napoje (22). Na skutek tych zmian w latach 2004-2016 istotnie zmniejszył się stopień koncentracji towarowej polskiego eksportu rolno-spożywczego do państw UE-13 (nadal pozostał jednak wysoki). Na dziesięć głównych grup towarowych w 2016 roku przypadało 79,3\% tego eksportu, czyli o 3,7 pkt proc. mniej niż w 2004 roku (83,0\%).

W analizowanym okresie wzrosła wartość importu wszystkich grup towarowych w imporcie rolno-spożywczym Polski z państw UE-13. W dziesięciu działach HS wzrost ten był wyższy od przeciętnego. Lista głównych grup towarowych w polskim imporcie rolno-spożywczym z UE-13 także uległa w tym okresie zmianom (tabela 2.3). Nie ma na niej już cukrów i wyrobów cukierniczych, przetworów z owoców i warzyw oraz różnych przetworów spożywczych, a znalazły się zwierzęta żywe (01), produkty mleczarskie (04) oraz nasiona i owoce oleiste (12). Do pozostałych grup towarowych obecnych na liście „top 10” w 2016 roku należały: napoje (22), odpady i pasze dla zwierząt (23), zboża (10), produkty młynarskie, słód i skrobie (11), przetwory zbożowe i pieczywo cukiernicze (19), thuszcze i oleje (15), oraz kakao i przetwory z kakao (18). Zmiany te wpłynęły na znaczące zmniejszenie stopnia koncentracji towarowej polskiego importu rolno-spożywczego z państw UE-13 (większe niż eksportu). W 2016 roku na dziesięć głównych działów HS przypadało 72,3\% tego importu, tj. aż o 6,2 pkt proc. mniej niż w 2004 roku (78,5\%).

W 2016 roku nadwyżka w obrotach handlowych produktami rolno-spożywczymi Polski z nowymi państwami członkowskimi wystąpiła aż w 18 działach HS (podobnie jak w 2004 roku), najwyższa jej wartość dotyczyła handlu mięsem i podrobami, tytoniem i wyrobami tytoniowymi, produktami mleczarskimi, różnymi przetworami spożywczymi oraz tłuszczami i olejami. Największy deficyt powodowała wymiana handlowa zwierzętami żywymi oraz nasionami i owocami oleistymi. 


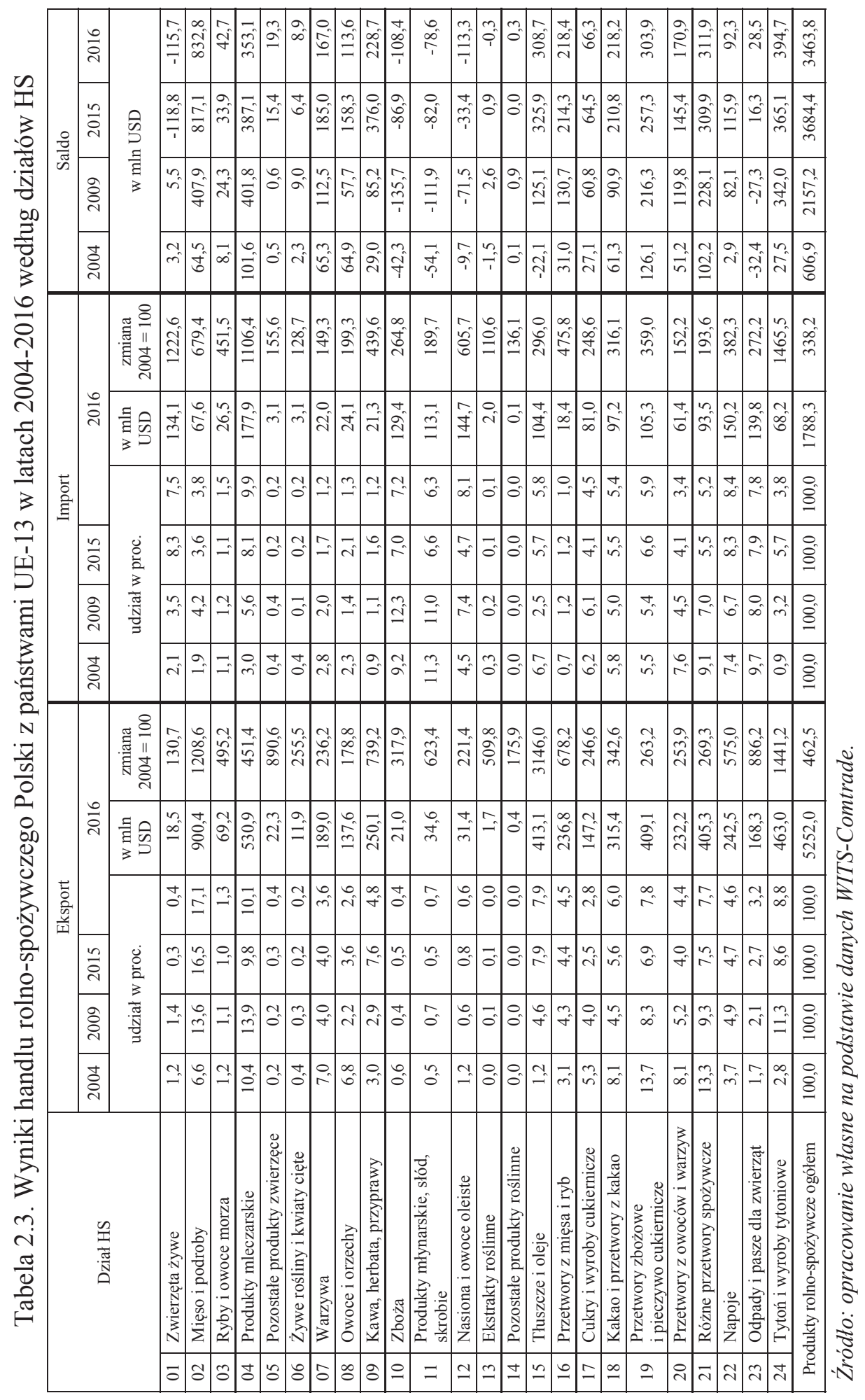




\subsubsection{Handel rolno-spożywczy Polski z krajami spoza UE - ujęcie towarowe}

W latach 2004-2016 w eksporcie rolno-spożywczym Polski do krajów spoza UE wzrosła wartość eksportu większości grup towarowych. W jedenastu działach HS odnotowano wzrost wyższy od przeciętnego, największy w przypadku zbóż, ekstraktów roślinnych oraz przetworów zbożowych i pieczywa cukierniczego. Na liście dziesięciu głównych grup towarowych zaszły w tym okresie tylko niewielkie zmiany (tabela 2.4). Nie występują na niej już warzywa, a w ich miejsce pojawiły się zboża (10). Do pozostałych grup towarowych obecnych na liście „top 10” w 2016 roku należały: mięso i podroby (02), przetwory zbożowe i pieczywo cukiernicze (19), produkty mleczarskie (04), owoce i orzechy (08), kakao i przetwory z kakao (18), różne przetwory spożywcze (21), przetwory z owoców i warzyw (20), tytoń i wyroby tytoniowe (24) oraz cukry i wyroby cukiernicze (17). W efekcie tych zmian, w analizowanym okresie wyraźnie wzrósł stopień koncentracji towarowej polskiego eksportu rolno-spożywczego do krajów trzecich. W 2016 roku na dziesięć głównych grup towarowych przypadało $77,8 \%$ tego eksportu, tj. o 5,0 pkt proc. więcej niż w 2004 roku $(72,8 \%)$.

W latach 2004-2016 wzrosła także wartość importu większości grup towarowych w imporcie rolno-spożywczym Polski z krajów spoza UE. W trzynastu grupach produktów wzrost ten był wyższy od przeciętnego. Lista dziesięciu głównych działów w polskim imporcie rolno-spożywczym z krajów trzecich także w tym okresie się zmieniła (tabela 2.4). Nie ma na niej już pozostałych produktów zwierzęcych oraz zbóż, a pojawiły się różne przetwory spożywcze (21) oraz napoje (22). Na liście „top 10” w 2016 roku znalazły się także następujące grupy towarowe: ryby i owoce morza (03), odpady i pasze dla zwierząt (23), owoce i orzechy (08), tytoń i wyroby tytoniowe (24), kawa, herbata i przyprawy (09), przetwory z owoców i warzyw (20), nasiona i owoce oleiste (12) oraz kakao i przetwory z kakao (18). Zmiany te wpłynęły na zwiększenie stopnia koncentracji towarowej polskiego importu rolno-spożywczego z krajów spoza UE. W 2016 roku na dziesięć głównych działów HS przypadało aż 87,2\% tego importu, czyli o 1,6 pkt proc. więcej niż w 2004 roku (85,6\%).

W 2016 roku dodatnie saldo obrotów handlowych produktami rolno-spożywczymi Polski z krajami trzecimi wystąpiło w 14 działach HS (w 2004 roku - w 12 działach), najwyższą jego wartość osiągnięto w handlu mięsem i podrobami, zbożami, przetworami zbożowymi i pieczywem cukierniczym oraz produktami mleczarskimi. Największy deficyt generowała wymiana handlowa rybami i owocami morza oraz odpadami i paszami dla zwierząt. 


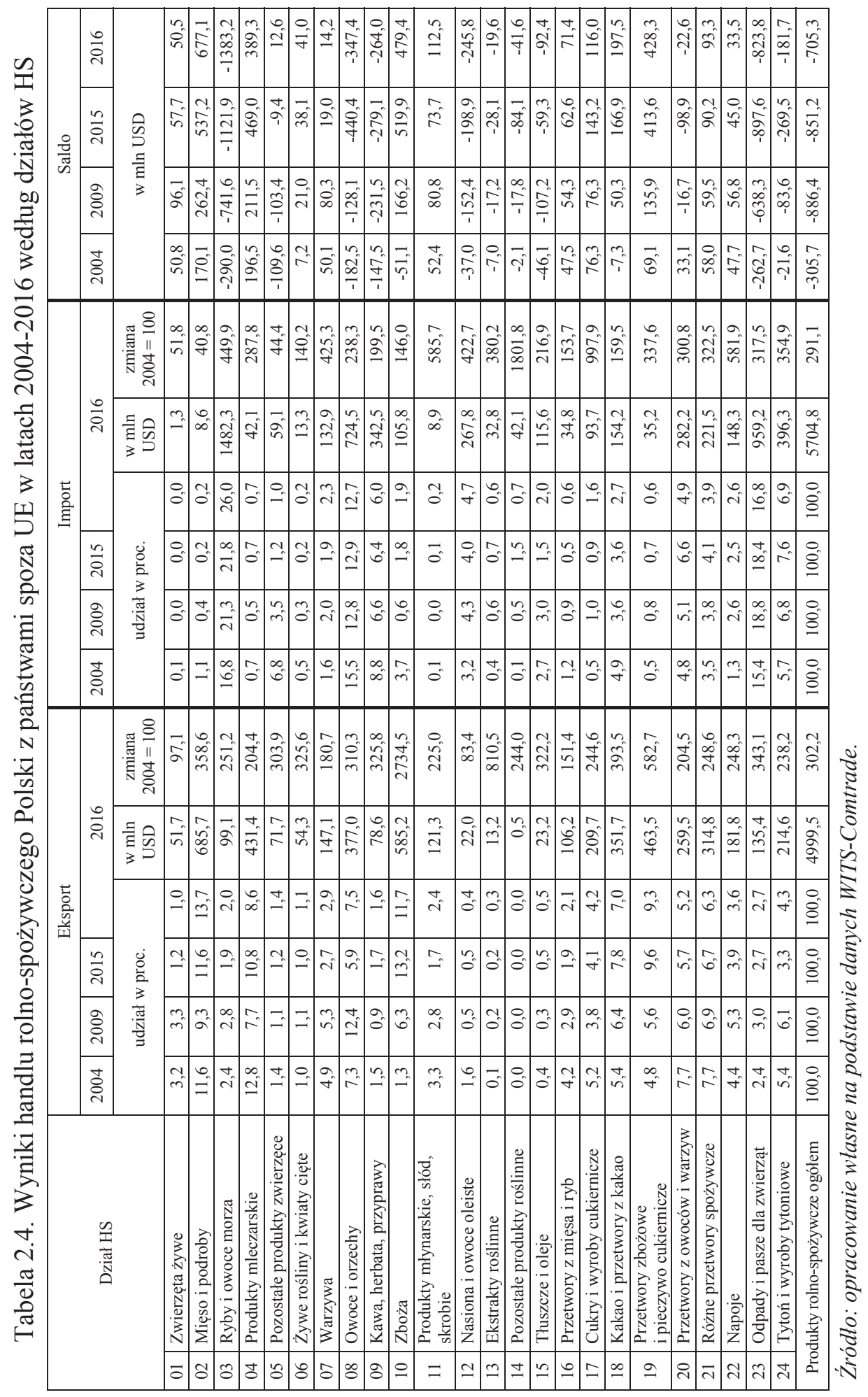


Bilans okresu członkostwa Polski w Unii Europejskiej dla podmiotów polskiego sektora rolno-spożywczego, które zdecydowały się rozwijać zagraniczną wymianę handlową i tym samym aktywnie uczestniczyć w procesie internacjonalizacji, okazał się zdecydowanie korzystny. Świadczą o tym bardzo dobre wyniki polskiego handlu zagranicznego produktami rolno-spożywczymi, w tym przede wszystkim dynamicznie rosnący eksport i wysokie dodatnie saldo obrotów handlowych. Najważniejszym partnerem handlowym Polski w tej wymianie niezmiennie pozostają państwa członkowskie Unii Europejskiej.

Handel rolno-spożywczy Polski - zarówno eksport, jak i import - charakteryzuje wyraźna koncentracja towarowa, a co za tym idzie specjalizacja eksportowa. Najwyższy stopień koncentracji towarowej eksportu charakteryzuje wymianę handlową z państwami UE-13, a importu - obroty handlowe z krajami spoza UE. Zaobserwowane zmiany struktury towarowej świadczą o rosnącej dywersyfikacji towarowej obu strumieni handlu, tj. rozszerzaniu oferty eksportowej produktów i imporcie nowych asortymentów towarów.

\subsection{Ocena przewag komparatywnych $w$ handlu produktami rolno- -spożywczymi Polski na wybranych rynkach}

\subsubsection{Tendencje ogólne}

W latach 2004-2016 wartości wskaźników RTA w polskim handlu produktami rolno-spożywczymi wykazywały różnokierunkowe wahania (wykres 2.4). W całym tym okresie Polska miała jednak relatywne przewagi komparatywne zarówno w handlu rolno-spożywczym na rynku światowym, jak i w handlu na poszczególnych rynkach. Najwyższe przewagi, niemal w całym analizowanym okresie, polscy producenci żywności odnotowywali na rynkach państw UE-13, a najniższe - nieprzerwanie na rynkach państw UE-15. W obu przypadkach wartości wskaźników RTA w latach 2004-2016 uległy jednak niewielkiemu obniżeniu - odpowiednio o 0,13 i 0,12 pkt. Najbardziej stabilny był wskaźnik relatywnej przewagi RTA na rynkach krajów spoza UE, który w badanym okresie obniżył się zaledwie o 0,06 pkt. Mimo spadku w okresie członkostwa w UE wskaźników RTA w polskim handlu produktami rolno-spożywczymi na wszystkich analizowanych rynkach Polska nadal posiadała relatywne przewagi w handlu tymi produktami. Były one przy tym wyraźnie wyższe w handlu z państwami UE-13 i krajami spoza UE niż z państwami UE-15. 
Wykres 2.4. Wskaźniki relatywnej przewagi RTA w handlu rolno-spożywczym Polski w latach 2004-2016

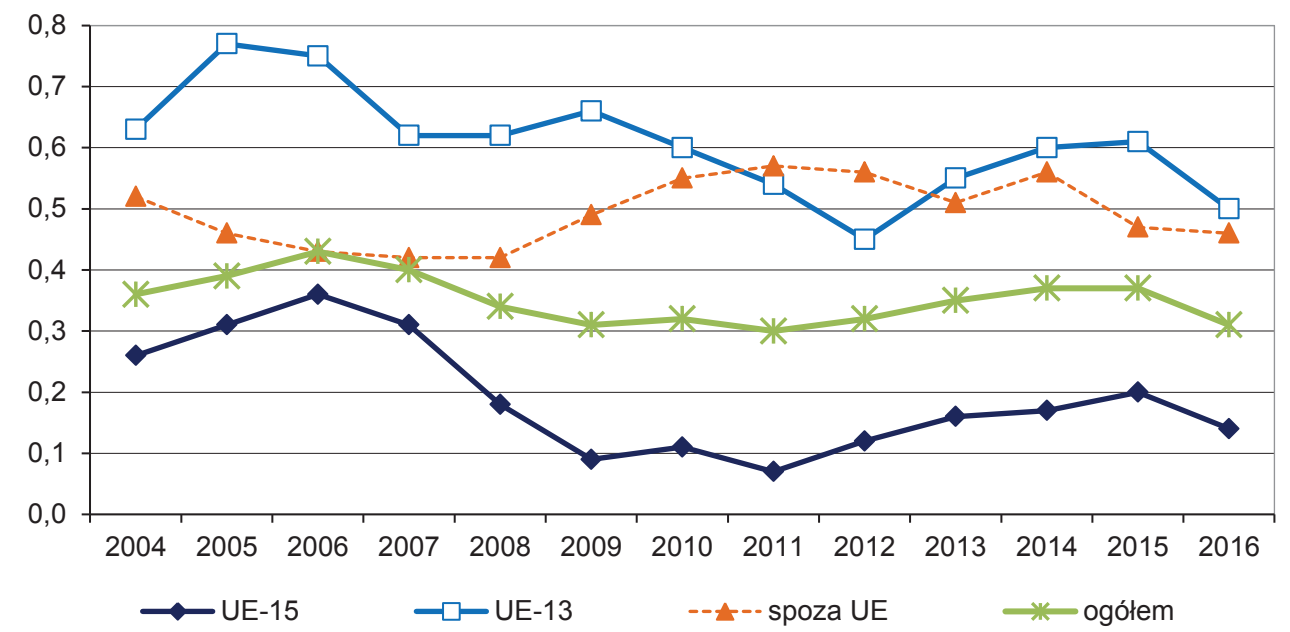

Źródto: opracowanie własne na podstawie danych WITS-Comtrade.

Przedstawione wartości wskaźników relatywnej przewagi RTA w polskim handlu rolno-spożywczym na rynku światowym i na wybranych rynkach stanowią duże uogólnienie. Rozpatrując wszystkie grupy produktów rolno-spożywczych łącznie, trudno jest przeprowadzić rzetelne wnioskowanie i sformułować obiektywne wnioski. Konieczna jest w związku z tym analiza przewag komparatywnych na poziomie poszczególnych grup produktów (działów HS).

\subsubsection{Handel rolno-spożywczy Polski ogólem}

W 2016 roku wskaźnik relatywnej przewagi RTA w handlu produktami rolno-spożywczymi Polski ogółem wyniósł 0,31, co oznacza, że Polska posiadała względne przewagi komparatywne w handlu tymi produktami na rynku światowym, a zatem była konkurencyjna na tym rynku. Poziom tych przewag zbliżony był do odnotowanego w 2009 roku, natomiast nieco niższy w porównaniu zarówno z 2004, jak i 2015 rokiem (w latach tych wskaźniki RTA wyniosły odpowiednio 0,36 i 0,37 ), co wskazywać może na niewielkie pogorszenie pozycji konkurencyjnej polskich producentów żywności na rynku światowym (tabela 2.5).

W 2016 roku, spośród 24 działów HS obejmujących produkty rolno-spożywcze, wskaźniki relatywnej przewagi RTA wyższe od 0 występowały w 16 działach, na które przypadało łącznie aż 72,7\% obrotów polskiego handlu rolno-spożywczego ogółem. Najwyższe wskaźniki RTA odnotowano w takich grupach produktów, jak: przetwory z mięsa i ryb $(1,71)$, zboża $(1,09)$, przetwory 
zbożowe i pieczywo cukiernicze $(1,01)$, tytoń i wyroby tytoniowe $(0,99)$ oraz mięso i podroby $(0,90)$. Łączny udział tych pięciu grup produktów w polskim handlu rolno-spożywczym ogółem przekraczał 1/3 (34,1\%). Nieco słabsze relatywne przewagi RTA dotyczyły handlu produktami mleczarskimi $(0,62)$, przetworami z owoców i warzyw $(0,52)$ oraz cukrami i wyrobami cukierniczymi $(0,40)$. Spośród siedmiu działów o najwyższym udziale w obrotach polskiego handlu rolno-spożywczego ogółem (mięso i podroby, ryby i owoce morza, tytoń i wyroby tytoniowe, przetwory zbożowe i pieczywo cukiernicze, produkty mleczarskie, kakao i przetwory z kakao, różne przetwory spożywcze) wskaźnik RTA poniżej 0 wystąpił tylko w przypadku wymiany handlowej rybami i owocami morza $(-0,41)$, co wiązać należy z dużą rolą importu w zaopatrzeniu surowcowym tego sektora gospodarki.

Tabela 2.5. Wskaźniki relatywnej przewagi RTA w handlu rolno-spożywczym Polski ogółem w latach 2004-2016 według działów HS

\begin{tabular}{|c|c|c|c|c|c|c|c|}
\hline & Dział HS & 2004 & 2009 & 2015 & 2016 & $\begin{array}{l}\text { Zmiana } \\
\text { w latach } \\
\end{array}$ & $\begin{array}{c}\text { Udział danego } \\
\text { działu w handlu } \\
\text { rolno-spożywczym }\end{array}$ \\
\hline 01 & Zwierzęta żywe & 1,31 & 0,25 & $-1,27$ & $-1,49$ & $-2,80$ & 1,8 \\
\hline 02 & Mięso i podroby & 1,08 & 0,45 & 0,92 & 0,90 & $-0,17$ & 13,4 \\
\hline 03 & Ryby i owoce morza & $-0,01$ & $-0,18$ & $-0,34$ & $-0,41$ & $-0,40$ & 7,6 \\
\hline 04 & Produkty mleczarskie & 2,14 & 1,22 & 0,78 & 0,62 & $-1,52$ & 6,5 \\
\hline 05 & Pozostałe produkty zwierzęce & $-0,31$ & $-0,43$ & 0,05 & 0,20 & 0,51 & 1,0 \\
\hline 06 & Żywe rośliny i kwiaty cięte & $-0,40$ & $-0,76$ & $-0,77$ & $-0,80$ & $-0,40$ & 0,9 \\
\hline 07 & Warzywa & 1,18 & 0,61 & 0,36 & 0,26 & $-0,93$ & 3,8 \\
\hline 08 & Owoce i orzechy & 0,05 & $-0,04$ & $-0,23$ & $-0,27$ & $-0,32$ & 5,9 \\
\hline 09 & Kawa, herbata, przyprawy & $-0,99$ & $-0,43$ & 0,12 & 0,00 & 0,99 & 2,9 \\
\hline 10 & Zboża & $-1,46$ & 0,80 & 1,26 & 1,09 & 2,55 & 3,5 \\
\hline 11 & Produkty młynarskie, słód, skrobie & $-0,47$ & $-0,31$ & $-0,17$ & 0,03 & 0,50 & 1,1 \\
\hline 12 & Nasiona i owoce oleiste & 0,20 & $-0,34$ & 0,24 & $-0,85$ & $-1,05$ & 2,0 \\
\hline 13 & Ekstrakty roślinne & $-1,80$ & $-1,88$ & $-1,84$ & $-1,73$ & 0,07 & 0,3 \\
\hline 14 & Pozostałe produkty roślinne & 0,82 & $-1,19$ & $-3,64$ & $-2,68$ & $-3,50$ & 0,1 \\
\hline 15 & Tłuszcze i oleje & $-1,57$ & $-0,18$ & $-0,20$ & $-0,35$ & 1,22 & 3,5 \\
\hline 16 & Przetwory z mięsa i ryb & 1,61 & 1,42 & 1,63 & 1,71 & 0,10 & 3,7 \\
\hline 17 & Cukry i wyroby cukiernicze & 1,19 & 0,12 & 0,47 & 0,40 & $-0,79$ & 2,5 \\
\hline 18 & Kakao i przetwory z kakao & 0,27 & 0,30 & 0,38 & 0,47 & 0,20 & 6,4 \\
\hline 19 & \begin{tabular}{|l} 
Przetwory zbożowe \\
i pieczywo cukiernicze
\end{tabular} & 0,85 & 0,64 & 0,91 & 1,01 & 0,16 & 6,6 \\
\hline 20 & Przetwory z owoców i warzyw & 1,10 & 0,63 & 0,31 & 0,52 & $-0,58$ & 4,5 \\
\hline 21 & Różne przetwory spożywcze & 0,10 & 0,36 & 0,45 & 0,36 & 0,27 & 6,1 \\
\hline 22 & Napoje & 0,04 & $-0,07$ & 0,05 & 0,00 & $-0,04$ & 3,8 \\
\hline 23 & Odpady i pasze dla zwierząt & $-1,16$ & $-1,04$ & $-0,72$ & $-0,75$ & 0,40 & 5,2 \\
\hline 24 & Tytoń i wyroby tytoniowe & 0,18 & 1,33 & 1,10 & 0,99 & 0,81 & 6,9 \\
\hline & Produkty rolno-spożywcze ogółem & 0,36 & 0,31 & 0,37 & 0,31 & $-0,05$ & 100,0 \\
\hline
\end{tabular}

Źródło: opracowanie własne na podstawie danych WITS-Comtrade. 
W latach 2004-2016 zmiany wskaźników relatywnej przewagi w handlu rolno-spożywczym Polski na rynku światowym były różnokierunkowe. Wskaźnik RTA wzrósł w 12 z 24 działów HS, najbardziej w przypadku zbóż (o 2,55pkt), a następnie tłuszczów i olejów (o 1,22 pkt) oraz kawy, herbaty i przypraw (o 0,99 pkt). W tym samym okresie wskaźnik ten znacząco zmniejszył się w handlu pozostałymi produktami roślinnymi (o 3,50 pkt), zwierzętami żywymi (o 2,80 pkt), produktami mleczarskimi (o $1,52 \mathrm{pkt}$ ) oraz nasionami i owocami oleistymi (o 1,05 pkt) - por. tabela 2.5 .

Wykres 2.5. Wskaźniki relatywnej przewagi RTA w handlu rolno-spożywczym

Polski ogółem w 2016 roku oraz ich zmiany w latach 2004-2016 według działów HS

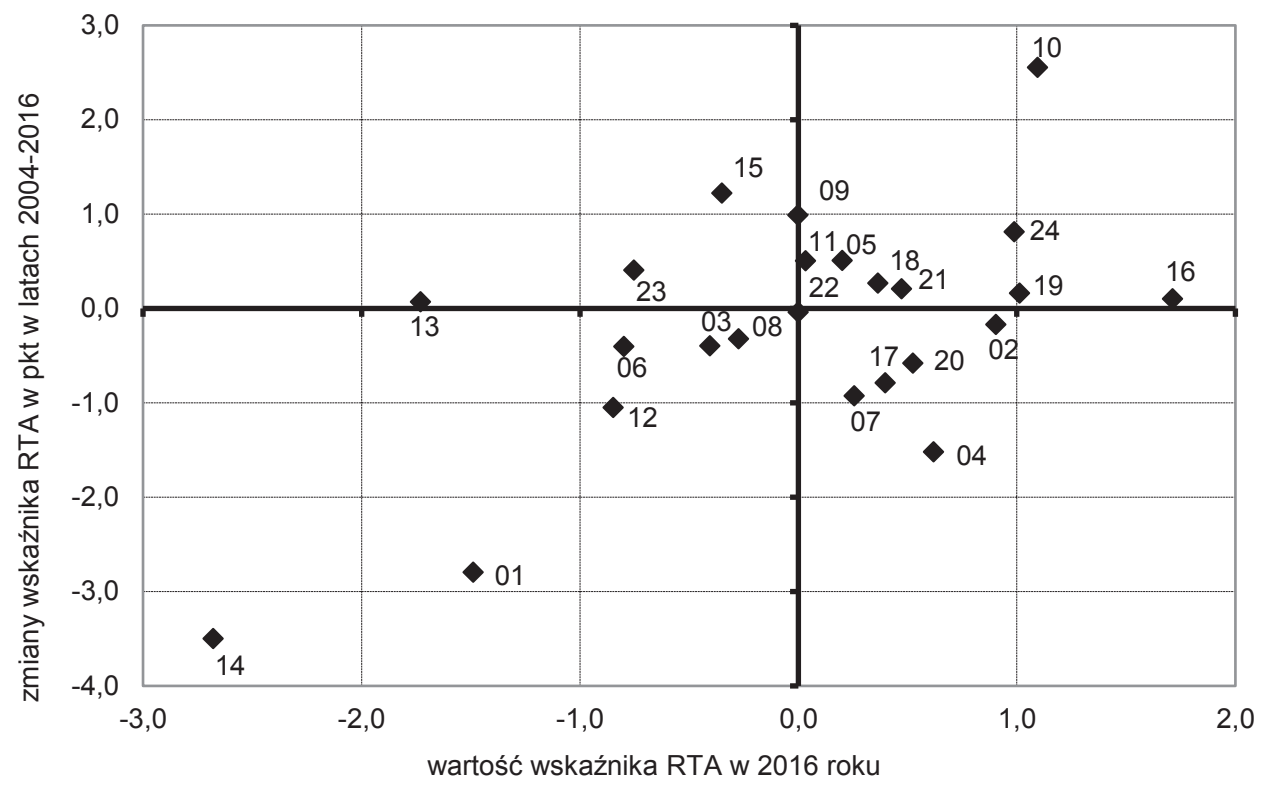

Uwaga: opis działów jak w tabelach 2.1-2.8.

Źródto: opracowanie własne na podstawie danych WITS-Comtrade.

Jednoczesne uwzględnienie wskaźników relatywnej przewagi RTA w handlu rolno-spożywczym Polski ogółem w 2016 roku oraz ich zmian w latach 2004-2016 pozwala wyróżnić cztery grupy działów HS (wykres 2.5). Pierwsza z nich to działy posiadające relatywne przewagi komparatywne w handlu w 2016 roku, które to przewagi $\mathrm{w}$ analizowanym okresie się umocniły. Z punktu widzenia konkurencyjności jest to niewątpliwie najkorzystniejsza sytuacja. Do grupy tej należy 9 następujących działów: przetwory z mięsa i ryb (16), zboża (10), tytoń 
i wyroby tytoniowe (24), przetwory zbożowe i pieczywo cukiernicze (19), różne przetwory spożywcze (21), kakao i przetwory z kakao (18), pozostałe produkty zwierzęce (05), produkty młynarskie, słód i skrobie (11) oraz kawa, herbata i przyprawy (09). Druga grupa obejmuje działy HS posiadające relatywne przewagi komparatywne w handlu w 2016 roku, które to przewagi w latach 2004-2016 uległy jednak zmniejszeniu. Były to takie działy, jak: produkty mleczarskie (04), mięso i podroby (02), warzywa (07), cukry i wyroby cukiernicze (17), przetwory z owoców i warzyw (20) oraz napoje (22).

Kolejna grupa zawiera działy, które mimo poprawy w analizowanym okresie wskaźnika RTA nie zdołały osiągnąć w 2016 roku minimalnych relatywnych przewag komparatywnych. W grupie tej znalazły się następujące grupy produktów: tłuszcze i oleje (15), odpady i pasze dla zwierząt (23) oraz ekstrakty roślinne (13). Ostatnia kombinacja wartości wskaźnika RTA w 2016 roku i jego zmian w latach 2004-2016 obejmuje te działy, w których nastąpiło pogorszenie relatywnej przewagi w handlu przy braku tej przewagi w 2016 roku. W handlu rolno-spożywczym Polski ogółem sytuacja ta wystąpiła w obrotach rybami i owocami morza (03), owocami i orzechami (08), żywymi roślinami i kwiatami (06), nasionami i owocami oleistymi (12), zwierzętami żywymi (01) oraz pozostałymi produktami roślinnymi (14). Większość z tych działów produkcji charakteryzuje się dużym udziałem importu w zaopatrzeniu surowcowym ${ }^{132}$.

\subsubsection{Handel rolno-spożywczy Polski z państwami UE-15}

Wskaźnik relatywnej przewagi RTA w handlu produktami rolno-spożywczymi Polski z państwami UE-15 w 2016 roku wyniósł 0,14, czyli Polska posiadała względne przewagi komparatywne w handlu tymi produktami i była konkurencyjna na rynku państw „Piętnastki”. Poziom tych przewag, chociaż wyższy od odnotowanego w 2009 roku $(0,09)$, był jednak niższy w porównaniu zarówno z 2004, jak i 2015 rokiem (w latach tych wskaźniki RTA wyniosły odpowiednio 0,26 i 0,20 ), co wskazuje na pewne pogorszenie pozycji konkurencyjnej polskich producentów żywności na rynkach państw UE-15 (tabela 2.6).

W 2016 roku połowa (12) wszystkich działów HS obejmujących produkty rolno-spożywcze charakteryzowała się wskaźnikami relatywnej przewagi RTA wyższymi od 0 . Na działy te przypadało łącznie $68,1 \%$ obrotów polskiego handlu rolno-spożywczego z państwami UE-15. Najwyższe wskaźniki RTA występowały w takich grupach produktów, jak: tytoń i wyroby tytoniowe $(1,20)$, przetwory z mięsa i ryb $(1,19)$, zboża $(1,16)$, przetwory zbożowe i pieczywo cukiernicze $(0,89)$

\footnotetext{
${ }^{132}$ I. Szczepaniak, Krajowe i importowane surowce $w$ produkcji żywności w Polsce, „Przemysł Spożywczy” 2017, nr 4, s. 2-5.
} 
oraz przetwory z owoców i warzyw $(0,49)$. Łączny udział tych pięciu grup produktów w polskim handlu rolno-spożywczym z państwami UE-15 przekraczał 1/4 (26,3\%). Nieco słabsze relatywne przewagi RTA dotyczyły handlu mięsem i podrobami $(0,47)$, produktami mleczarskimi $(0,24)$ oraz produktami młynarskimi, słodem i skrobiami (0,23). Spośród siedmiu działów o najwyższym udziale w obrotach handlowych produktami rolno-spożywczymi Polski z państwami „Piętnastki” (mięso i podroby, kakao i przetwory z kakao, przetwory zbożowe i pieczywo cukiernicze, tytoń i wyroby tytoniowe, produkty mleczarskie, ryby i owoce morza, różne przetwory spożywcze) wskaźnik relatywnej przewagi RTA poniżej 0 wystąpił tylko w przypadku wymiany handlowej kakao i przetworami z kakao $(-0,07)$.

Tabela 2.6. Wskaźniki relatywnej przewagi RTA w handlu rolno-spożywczym Polski z państwami UE-15 w latach 2004-2016 według działów HS

\begin{tabular}{|c|c|c|c|c|c|c|c|}
\hline \multicolumn{2}{|r|}{ Dział HS } & \multirow{2}{*}{$\begin{array}{r}2004 \\
1,18\end{array}$} & \multirow{2}{*}{$\begin{array}{r}2009 \\
-0,18\end{array}$} & \multirow{2}{*}{$\begin{array}{r}2015 \\
-1,66\end{array}$} & \multirow{2}{*}{$\begin{array}{r}2016 \\
-1,80\end{array}$} & \multirow{2}{*}{$\begin{array}{c}\begin{array}{c}\text { Zmiana } \\
\text { w latach } \\
2004-2016 \\
\text { (w pkt) }\end{array} \\
-2,98\end{array}$} & \multirow{2}{*}{$\begin{array}{l}\text { Udział danego } \\
\text { działu w handlu } \\
\text { rolno-spożywczym } \\
\text { w } 2016 \text { roku } \\
\text { (w proc.) } \\
2,2\end{array}$} \\
\hline 01 & Zwierzęta żywe & & & & & & \\
\hline 02 & Mięso i podroby & 0,72 & 0,03 & 0,47 & 0,47 & $-0,24$ & 16,2 \\
\hline 03 & Ryby i owoce morza & 0,54 & 0,34 & 0,03 & 0,03 & $-0,51$ & 6,4 \\
\hline 04 & Produkty mleczarskie & 2,06 & 0,84 & 0,36 & 0,24 & $-1,82$ & 6,5 \\
\hline 05 & Pozostałe produkty zwierzęce & 0,39 & $-0,27$ & $-0,23$ & $-0,12$ & $-0,51$ & 1,2 \\
\hline 06 & Żywe rośliny i kwiaty cięte & $-0,64$ & $-1,20$ & $-1,42$ & $-1,55$ & $-0,91$ & 1,2 \\
\hline 07 & Warzywa & 0,95 & 0,19 & $-0,02$ & $-0,12$ & $-1,06$ & 4,6 \\
\hline 08 & Owoce i orzechy & $-0,50$ & $-0,85$ & $-0,90$ & $-1,00$ & $-0,50$ & 5,0 \\
\hline 09 & Kawa, herbata, przyprawy & $-2,10$ & $-1,19$ & $-1,06$ & $-0,96$ & 1,14 & 2,2 \\
\hline 10 & Zboża & $-1,73$ & 1,23 & 1,34 & 1,16 & 2,88 & 2,7 \\
\hline 11 & Produkty młynarskie, słód, skrobie & $-0,98$ & $-0,01$ & 0,25 & 0,23 & 1,21 & 0,8 \\
\hline 12 & Nasiona i owoce oleiste & $-0,18$ & $-0,30$ & 0,11 & $-0,86$ & $-0,68$ & 1,5 \\
\hline 13 & Ekstrakty roślinne & $-1,70$ & $-3,39$ & $-2,96$ & $-3,33$ & $-1,63$ & 0,3 \\
\hline 14 & Pozostałe produkty roślinne & 1,56 & $-0,54$ & $-1,53$ & $-0,40$ & $-1,96$ & 0,0 \\
\hline 15 & Thuszcze i oleje & $-1,90$ & $-0,84$ & $-1,41$ & $-1,44$ & 0,46 & 3,3 \\
\hline 16 & Przetwory z mięsa i ryb & 1,29 & 0,86 & 1,07 & 1,19 & $-0,10$ & 4,8 \\
\hline 17 & Cukry i wyroby cukiernicze & 1,06 & $-0,38$ & 0,05 & 0,16 & $-0,89$ & 2,1 \\
\hline 18 & Kakao i przetwory z kakao & $-0,22$ & $-0,22$ & $-0,20$ & $-0,07$ & 0,15 & 7,3 \\
\hline 19 & $\begin{array}{l}\text { Przetwory zbożowe } \\
\text { i pieczywo cukiernicze }\end{array}$ & 0,29 & 0,32 & 0,75 & 0,89 & 0,60 & 7,2 \\
\hline 20 & Przetwory z owoców i warzyw & 1,35 & 0,55 & 0,32 & 0,49 & $-0,86$ & 4,4 \\
\hline 21 & Różne przetwory spożywcze & $-0,63$ & 0,15 & 0,32 & 0,20 & 0,83 & 6,3 \\
\hline 22 & Napoje & $-0,22$ & $-0,44$ & 0,14 & 0,16 & 0,37 & 3,5 \\
\hline 23 & Odpady i pasze dla zwierząt & $-1,27$ & $-0,81$ & $-0,38$ & $-0,35$ & 0,92 & 3,3 \\
\hline 24 & Tytoń i wyroby tytoniowe & $-0,19$ & 1,90 & 1,47 & 1,20 & 1,39 & 7,2 \\
\hline \multicolumn{2}{|r|}{ Produkty rolno-spożywcze ogółem } & 0,26 & 0,09 & 0,20 & 0,14 & $-0,12$ & 100,0 \\
\hline
\end{tabular}

Źródło: opracowanie własne na podstawie danych WITS-Comtrade. 
W analizowanym okresie wskaźniki relatywnej przewagi komparatywnej w handlu rolno-spożywczym Polski z państwami UE-15 zmieniały się różnokierunkowo, jednak przeważały spadki tego miernika. Spośród 24 działów HS wskaźnik RTA zmniejszył się bowiem w przypadku 14 działów, najbardziej w handlu zwierzętami żywymi (o 2,98 pkt), pozostałymi produktami roślinnymi (o 1,96 pkt), produktami mleczarskimi (o 1,82 pkt) oraz ekstraktami roślinnymi (o 1,63 pkt). W latach 2004-2016 wskaźnik ten wzrósł natomiast znacząco w grupie zbóż (o 2,88 pkt), a następnie tytoniu i wyrobów tytoniowych (o 1,39 pkt), produktów młynarskich, słodu i skrobi (o 1,21 pkt) oraz kawy, herbaty i przypraw (o 1,14 pkt) - por. tabela 2.6.

Wykres 2.6. Wskaźniki relatywnej przewagi RTA w handlu rolno-spożywczym Polski z państwami UE-15 w 2016 roku oraz ich zmiany w latach 2004-2016 według działów HS

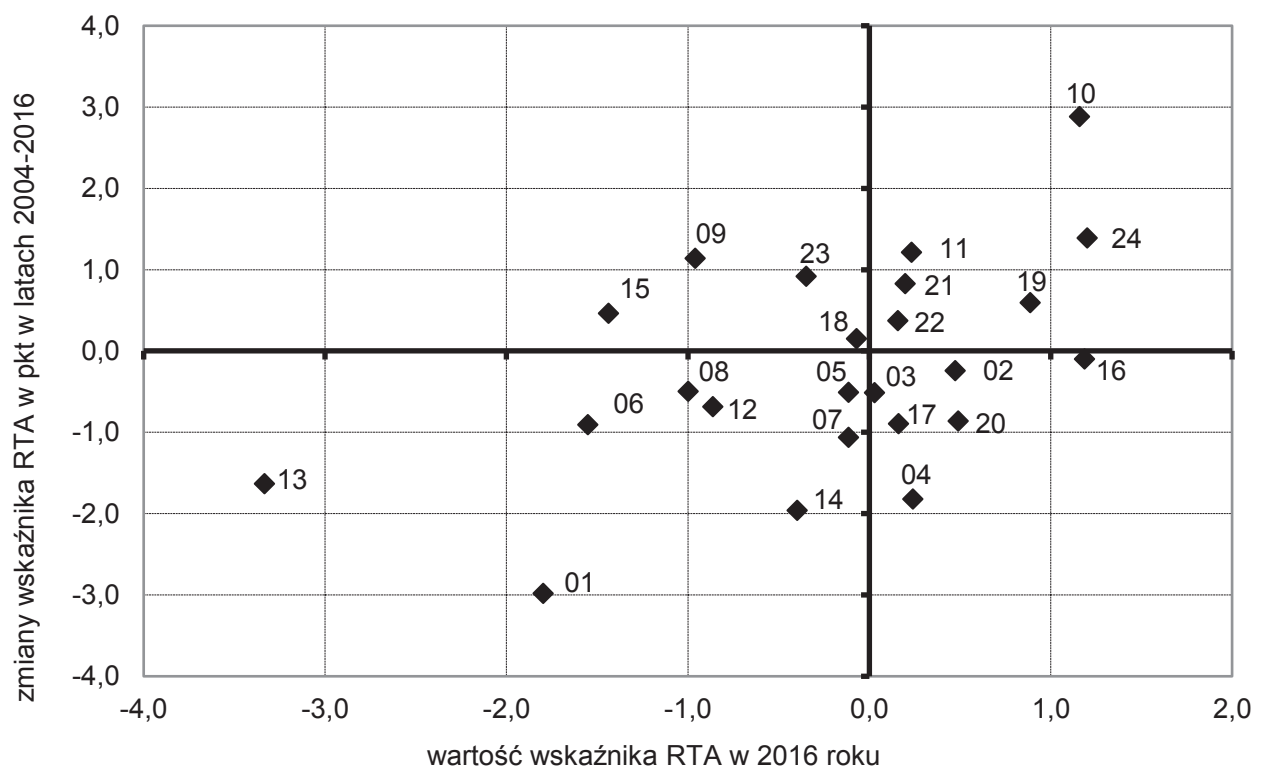

Uwaga: opis działów jak w tabelach 2.1-2.8.

Źródto: opracowanie wtasne na podstawie danych WITS-Comtrade.

Przedstawiony na wykresie 2.6 podział działów HS pod względem poziomu i zmian wskaźników relatywnej przewagi RTA w handlu rolno-spożywczym Polski z państwami UE-15 na cztery grupy pozwolił do pierwszej z nich zakwalifikować działy odznaczające się relatywnymi przewagami komparatywnymi w handlu w 2016 roku, które to przewagi w analizowanym okresie się zwiększyły. Grupę tę tworzą następujące działy: zboża (10), tytoń i wyroby 
tytoniowe (24), przetwory zbożowe i pieczywo cukiernicze (19), produkty młynarskie, słód i skrobie (11), różne przetwory spożywcze (21) oraz napoje (22). Druga grupa obejmuje działy HS, w zakresie których Polska posiadała relatywne przewagi komparatywne w handlu w 2016 roku, które to przewagi w latach 2004-2016 uległy jednak zmniejszeniu. Były to takie działy, jak: przetwory z mięsa i ryb (16), mięso i podroby (02), przetwory z owoców i warzyw (20), produkty mleczarskie (04), cukry i wyroby cukiernicze (17) oraz ryby i owoce morza (03).

Trzecia grupa obejmuje działy, które mimo poprawy w analizowanym okresie wskaźnika RTA nie zdołały osiągnąć w 2016 roku minimalnych relatywnych przewag komparatywnych. W grupie tej znalazły się następujące działy: thuszcze i oleje (15), kawa, herbata i przyprawy (09), odpady i pasze dla zwierząt (23) oraz kakao i przetwory z kakao (18). Ostatnia kombinacja wartości wskaźnika RTA w 2016 roku i jego zmian w latach 2004-2016 obejmuje te grupy produktów, w których wymianie handlowej nastąpiło pogorszenie relatywnej przewagi, przy jej braku w 2016 roku. W handlu rolno-spożywczym Polski z UE-15 sytuacja ta wystąpiła w obrotach aż ośmiu grupami produktów, tj. ekstraktami roślinnymi (13), zwierzętami żywymi (01), owocami i orzechami (08), żywymi roślinami i kwiatami (06), nasionami i owocami oleistymi (12), warzywami (07) oraz pozostałymi produktami zwierzęcymi (05) i roślinnymi (14). Grupy te miały jednak na ogół minimalny udział w obrotach handlowych (z wyjątkiem warzyw oraz owoców i orzechów).

\subsubsection{Handel rolno-spożywczy Polski z państwami UE-13}

W 2016 roku wskaźnik relatywnej przewagi RTA w handlu produktami rolno-spożywczymi Polski z państwami UE-13 wyniósł 0,50. Oznacza to, że Polska posiadała dość wysokie względne przewagi komparatywne w handlu tymi produktami i była konkurencyjna na rynkach nowych państw członkowskich. Poziom tych przewag był jednak nieco niższy niż w latach poprzednich (w latach 2004, 2009 i 2015 wskaźniki RTA wyniosły odpowiednio 0,63, 0,66 i 0,61), a zatem nastąpiło niewielkie osłabienie pozycji konkurencyjnej polskich producentów żywności na rynkach państw UE-13 (tabela 2.7).

Spośród 24 działów HS obejmujących produkty rolno-spożywcze wskaźniki relatywnej przewagi RTA wyższe od 0 występowały w 15 działach, na które przypadało łącznie aż 79,6\% obrotów polskiego handlu rolno-spożywczego z państwami UE-13 w 2016 roku. Najwyższe wskaźniki RTA występowały $\mathrm{w}$ takich działach produkcji, jak: przetwory z mięsa i ryb $(2,32)$, tytoń i wyroby tytoniowe $(2,25)$, mięso i podroby $(2,07)$, pozostałe produkty zwierzęce $(1,32)$ 
oraz warzywa $(1,25)$. Łączny udział tych pięciu grup produktów w polskim handlu rolno-spożywczym z państwami UE-13 przekraczał 1/4 (28,3\%). Nieco słabsze relatywne przewagi RTA dotyczyły handlu kawą, herbatą i przyprawami $(1,01)$, przetworami zbożowymi i pieczywem cukierniczym $(0,91)$ oraz produktami mleczarskimi $(0,74)$. We wszystkich siedmiu działach o najwyższym udziale w obrotach handlowych produktami rolno-spożywczymi Polski z nowymi państwami członkowskimi (mięso i podroby, produkty mleczarskie, tytoń i wyroby tytoniowe, tłuszcze i oleje, przetwory zbożowe i pieczywo cukiernicze, różne przetwory spożywcze, kakao i przetwory z kakao) wskaźnik relatywnej przewagi RTA był dodatni. Przedmiotem wymiany handlowej były zatem przede wszystkim te produkty, w zakresie których Polska posiadała przewagi komparatywne.

Tabela 2.7. Wskaźniki relatywnej przewagi RTA w handlu rolno-spożywczym Polski z państwami UE-13 w latach 2004-2016 według działów HS

\begin{tabular}{|c|c|c|c|c|c|c|c|}
\hline \multicolumn{2}{|r|}{ Dział HS } & \multirow{2}{*}{$\begin{array}{r}2004 \\
1,10\end{array}$} & \multirow{2}{*}{$\begin{array}{r}2009 \\
0,08 \\
\end{array}$} & \multirow{2}{*}{$\begin{array}{l}2015 \\
-2,62\end{array}$} & \multirow{2}{*}{$\begin{array}{r}2016 \\
-2,51\end{array}$} & \multirow{2}{*}{\begin{tabular}{|c|}
$\begin{array}{c}\text { Zmiana } \\
\text { w latach }\end{array}$ \\
$\begin{array}{c}2004-2016 \\
\text { (w pkt) }\end{array}$ \\
$-3,61$ \\
\end{tabular}} & \multirow{2}{*}{$\begin{array}{c}\text { Udział danego } \\
\text { działu w handlu } \\
\text { rolno-spożywczym } \\
\text { w 2016 roku } \\
\text { (w proc.) } \\
2,2\end{array}$} \\
\hline 01 & Zwierzęta żywe & & & & & & \\
\hline 02 & Mięso i podroby & 1,99 & 1,60 & 2,15 & 2,07 & 0,09 & 13,8 \\
\hline 03 & Ryby i owoce morza & 0,44 & 0,30 & $-0,11$ & $-0,30$ & $-0,74$ & 1,4 \\
\hline 04 & Produkty mleczarskie & 2,76 & 2,03 & 1,08 & 0,74 & $-2,02$ & 10,1 \\
\hline 05 & Pozostałe produkty zwierzęce & $-0,09$ & $-0,62$ & 1,03 & 1,32 & 1,41 & 0,4 \\
\hline 06 & Żywe rośliny i kwiaty cięte & $-0,65$ & 0,61 & $-0,72$ & $-0,47$ & 0,19 & 0,2 \\
\hline 07 & Warzywa & 1,77 & 1,13 & 1,06 & 1,25 & $-0,51$ & 3,0 \\
\hline 08 & Owoce i orzechy & 1,35 & 0,39 & 0,26 & 0,36 & $-0,99$ & 2,3 \\
\hline 09 & Kawa, herbata, przyprawy & 0,61 & 0,60 & 1,28 & 1,01 & 0,40 & 3,9 \\
\hline 10 & Zboża & $-1,75$ & $-1,48$ & $-0,82$ & $-1,20$ & 0,55 & 2,1 \\
\hline 11 & Produkty młynarskie, słód, skrobie & $-2,33$ & $-1,86$ & $-1,74$ & $-1,37$ & 0,96 & 2,1 \\
\hline 12 & Nasiona i owoce oleiste & 0,04 & $-1,14$ & $-0,39$ & $-1,40$ & $-1,44$ & 2,5 \\
\hline 13 & Ekstrakty roślinne & $-2,64$ & $-0,29$ & $-0,98$ & $-1,32$ & 1,32 & 0,1 \\
\hline 14 & Pozostałe produkty roślinne & 2,41 & 2,36 & $-1,78$ & 0,83 & $-1,58$ & 0,0 \\
\hline 15 & Tłuszcze i oleje & $-1,75$ & 0,87 & 0,61 & 0,33 & 2,08 & 7,3 \\
\hline 16 & Przetwory z mięsa i ryb & 2,46 & 2,25 & 2,19 & 2,32 & $-0,14$ & 3,6 \\
\hline 17 & Cukry i wyroby cukiernicze & 0,75 & 0,06 & 0,13 & 0,01 & $-0,73$ & 3,2 \\
\hline 18 & Kakao i przetwory z kakao & 0,62 & 0,18 & 0,35 & 0,34 & $-0,28$ & 5,9 \\
\hline 19 & $\begin{array}{l}\text { Przetwory zbożowe } \\
\text { i pieczywo cukiernicze }\end{array}$ & 1,29 & 1,05 & 0,73 & 0,91 & $-0,37$ & 7,3 \\
\hline 20 & Przetwory z owoców i warzyw & 1,01 & 0,81 & 0,41 & 0,60 & $-0,41$ & 4,2 \\
\hline 21 & Różne przetwory spożywcze & 0,51 & 0,78 & 0,81 & 0,79 & 0,29 & 7,1 \\
\hline 22 & Napoje & $-0,17$ & 0,04 & $-0,39$ & $-0,48$ & $-0,31$ & 5,6 \\
\hline 23 & Odpady i pasze dla zwierząt & $-1,56$ & $-1,03$ & $-0,83$ & $-0,65$ & 0,91 & 4,4 \\
\hline 24 & Tytoń i wyroby tytoniowe & 1,43 & 2,53 & 1,92 & 2,25 & 0,81 & 7,5 \\
\hline \multicolumn{2}{|r|}{ Produkty rolno-spożywcze ogółem } & 0,63 & 0,66 & 0,61 & 0,50 & $-0,13$ & 100,0 \\
\hline
\end{tabular}

Źródto: opracowanie własne na podstawie danych WITS-Comtrade. 
W latach 2004-2016 zmiany wskaźników relatywnej przewagi w handlu rolno-spożywczym Polski z państwami UE-13 również były dwukierunkowe. Wskaźnik RTA wzrósł w 11 z 24 działów HS, najbardziej w przypadku tłuszczów i olejów (o 2,08 pkt), a następnie pozostałych produktów zwierzęcych (o 1,41pkt) oraz ekstraktów roślinnych (o 1,32 pkt). W tym samym okresie wskaźnik ten znacząco zmniejszył się w handlu zwierzętami żywymi (o 3,61 pkt), produktami mleczarskimi (o 2,02 pkt), pozostałymi produktami roślinnymi (o 1,58 pkt) oraz nasionami i owocami oleistymi (o 1,44 pkt) - por. tabela 2.7.

Wykres 2.7. Wskaźniki relatywnej przewagi RTA w handlu rolno-spożywczym Polski z państwami UE-13 w 2016 roku oraz ich zmiany w latach 2004-2016 według działów HS

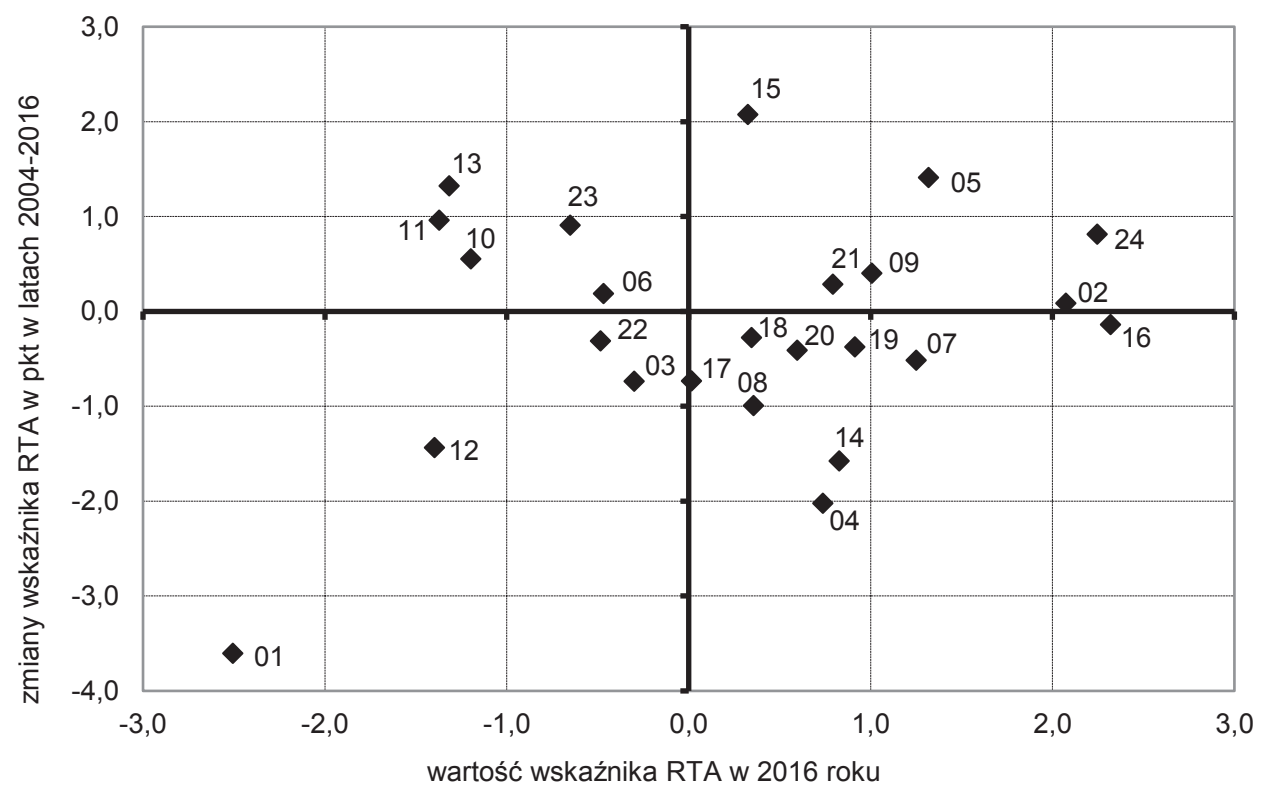

Uwaga: opis działów jak w tabelach 2.1-2.8.

Źródto: opracowanie wtasne na podstawie danych WITS-Comtrade.

Do działów HS charakteryzujących się w 2016 roku relatywnymi przewagami komparatywnymi w handlu rolno-spożywczym z państwami UE-13, które to przewagi w latach 2004-2016 zwiększyły się, należą (wykres 2.7): tłuszcze i oleje (15), mięso i podroby (02), pozostałe produkty zwierzęce (05), tytoń i wyroby tytoniowe (24), kawa, herbata i przyprawy (09) oraz różne przetwory spożywcze (21). Działy HS, w zakresie których Polska posiadała relatywne przewagi komparatywne w handlu z nowymi państwami członkowskimi w 2016 roku, które to przewagi w analizowanym okresie uległy jednak zmniejszeniu, 
obejmowały takie produkty, jak: przetwory z mięsa i ryb (16), kakao i przetwory z kakao (18), cukry i wyroby cukiernicze (17), przetwory z owoców i warzyw (20), przetwory zbożowe i pieczywo cukiernicze (19), owoce i orzechy (08), warzywa (07), produkty mleczarskie (04) oraz pozostałe produkty roślinne (14).

Do działów, które mimo poprawy wskaźnika RTA w latach 2004-2016 nie zdołały osiągnąć w 2016 roku minimalnych relatywnych przewag komparatywnych w handlu z państwami UE-13, zakwalifikowały się: zboża (10), produkty młynarskie, słód i skrobie (11), ekstrakty roślinne (13), odpady i pasze dla zwierząt (23) oraz żywe rośliny i kwiaty (06). Ostatnia kombinacja wartości wskaźnika RTA w 2016 roku i jego zmian w latach 2004-2016 obejmuje te grupy produktów, w których wymianie handlowej nastąpiło pogorszenie relatywnej przewagi, przy jej braku w 2016 roku. W handlu rolno-spożywczym Polski z UE-13 sytuacja ta wystąpiła w obrotach tylko czterema grupami produktów, tj. zwierzętami żywymi (01), nasionami i owocami oleistymi (12), rybami i owocami morza (03) oraz napojami (22).

\subsubsection{Handel rolno-spożywczy Polski z krajami spoza UE}

W 2016 roku Polska posiadała dość wysokie względne przewagi komparatywne w handlu produktami rolno-spożywczymi z krajami spoza UE. Wskazuje na to dość wysoki wskaźnik relatywnej przewagi RTA w handlu tymi produktami, który wyniósł 0,46. Oznacza to, że polska żywność była konkurencyjna na rynkach krajów trzecich. Poziom tych przewag w 2016 roku był podobny jak przed rokiem $(0,47)$, ale nieco niższy w porównaniu zarówno z 2004, jak i 2009 rokiem (w latach 2004 i 2009 wskaźniki RTA wyniosły odpowiednio 0,52 i 0,49), a zatem nastąpiło nieznaczne osłabienie pozycji konkurencyjnej polskich producentów żywności na rynku pozaunijnym (tabela 2.8).

W 2016 roku spośród 24 działów HS obejmujących produkty rolno-spożywcze wskaźniki relatywnej przewagi RTA wyższe od 0 występowały aż w 16 działach, na które przypadało łącznie $60,5 \%$ obrotów polskiego handlu rolno-spożywczego z krajami spoza UE. Najwyższe wskaźniki RTA występowały w takich grupach produktów, jak: mięso i podroby $(4,76)$, zwierzęta żywe $(3,98)$, produkty młynarskie, słód i skrobie $(2,88)$, przetwory zbożowe i pieczywo cukiernicze $(2,77)$, produkty mleczarskie $(2,53)$. Łączny udział tych pięciu grup produktów w polskim handlu rolno-spożywczym z krajami spoza UE wyniósł $17,3 \%$. Nieco słabsze, aczkolwiek wysokie, relatywne przewagi RTA dotyczyły handlu zbożami $(2,21)$, żywymi roślinami i kwiatami $(1,94)$ oraz przetworami z mięsa i ryb $(1,81)$. Spośród siedmiu działów o najwyższym udziale w obrotach polskiego handlu rolno-spożywczego z krajami spoza UE (ryby i owoce morza, 
owoce i orzechy, odpady i pasze dla zwierząt, mięso i podroby, zboża, tytoń i wyroby tytoniowe, przetwory z owoców i warzyw) wskaźnik RTA poniżej 0 wystąpił w przypadku wymiany handlowej trzema grupami produktów, tj. rybami i owocami morza $(-1,81)$, odpadami i paszami dla zwierząt $(-1,26)$ oraz tytoniem i wyrobami tytoniowymi $(-0,09)$.

Tabela 2.8. Wskaźniki relatywnej przewagi RTA w handlu rolno-spożywczym Polski z krajami spoza UE w latach 2004-2016 według działów HS

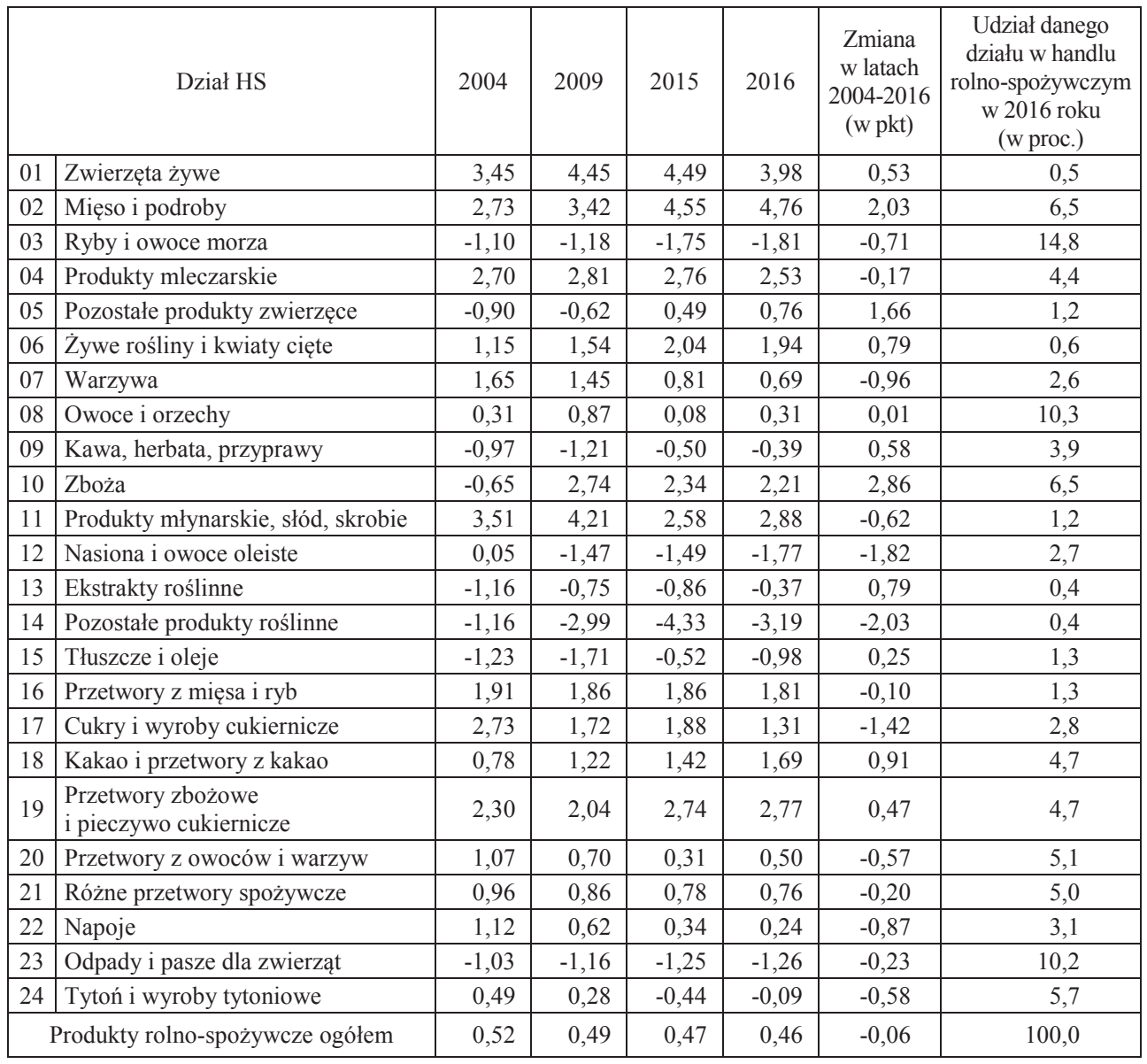

Źródto: opracowanie własne na podstawie danych WITS-Comtrade.

W latach 2004-2016 wskaźniki relatywnej przewagi w handlu rolno-spożywczym Polski z krajami trzecimi wzrosły w 11 z 24 działów HS, najbardziej w przypadku zbóż (o 2,86 pkt), a następnie mięsa i podrobów (o 2,03pkt), pozostałych produktów zwierzęcych (o 1,66 pkt) oraz ekstraktów roślinnych (o 1,32 pkt). W zakresie wymiany handlowej pozostałymi grupami produktów 
wskaźniki RTA w analizowanym okresie obniżyły się, szczególnie w handlu pozostałymi produktami roślinnymi (o 2,03 pkt), nasionami i owocami oleistymi (o $1,82 \mathrm{pkt}$ ) oraz rybami i owocami morza (o $0,71 \mathrm{pkt}$ ) - por. tabela 2.8 .

Wykres 2.8. Wskaźniki relatywnej przewagi RTA w handlu rolno-spożywczym Polski z krajami spoza UE w 2016 roku oraz ich zmiany w latach 2004-2016 według działów HS

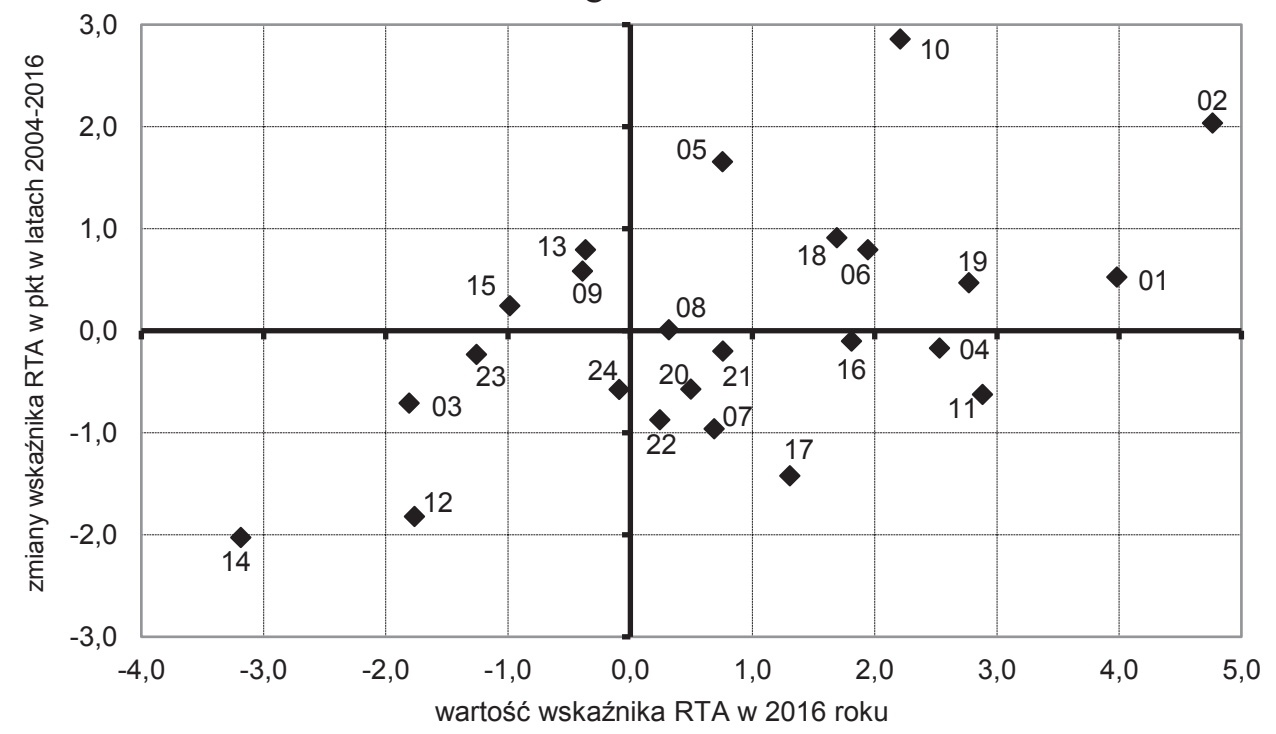

Uwaga: opis działów jak w tabelach 2.1-2.8.

Źródto: opracowanie własne na podstawie danych WITS-Comtrade.

Przedstawiony na wykresie 2.8 podział działów HS pod względem poziomu i zmian wskaźników relatywnej przewagi RTA w handlu rolno-spożywczym Polski z krajami spoza UE pozwolił do pierwszej grupy zakwalifikować działy odznaczające się relatywnymi przewagami komparatywnymi w handlu w 2016 roku, które to przewagi w latach 2004-2016 się zwiększyły. Grupę tę utworzyły następujące działy: mięso i podroby (02), zwierzęta żywe (01), przetwory zbożowe i pieczywo cukiernicze (19), zboża (10), żywe rośliny i kwiaty (06), kakao i przetwory z kakao (18), owoce i orzechy (08) oraz pozostałe produkty zwierzęce (05). W grupie działów HS, w zakresie których Polska posiadała w 2016 roku relatywne przewagi komparatywne $\mathrm{w}$ handlu $\mathrm{z}$ krajami trzecimi, które to przewagi w analizowanym okresie uległy jednak zmniejszeniu, znalazły się natomiast takie produkty, jak: produkty młynarskie, słód i skrobie (11), produkty mleczarskie (04), przetwory z mięsa i ryb (16), cukry i wyroby cukiernicze (17), warzywa (07), przetwory z owoców i warzyw (20), napoje (22) oraz różne przetwory spożywcze (21). 
Do działów, które mimo poprawy wskaźnika RTA w latach 2004-2016 nie zdołały osiągnąć w 2016 roku minimalnych relatywnych przewag komparatywnych w handlu z krajami spoza UE zakwalifikowały się: kawa, herbata i przyprawy (09), ekstrakty roślinne (13) oraz thuszcze i oleje (15). Ostatnią grupę działów tworzą te grupy produktów, w których wymianie handlowej nastąpiło pogorszenie relatywnej przewagi w latach 2004-2016, przy jej braku w 2016 roku. W handlu rolno-spożywczym Polski z krajami spoza UE sytuacja ta wystąpiła w obrotach pięcioma grupami produktów, tj.: nasionami i owocami oleistymi (12), rybami i owocami morza (03), odpadami i paszami dla zwierząt (23), tytoniem i wyrobami tytoniowymi (24) oraz pozostałymi produktami roślinnymi (14).

Przeprowadzona analiza relatywnych przewag w handlu rolno-spożywczym wykazała, że mimo spadku w latach 2004-2016 wskaźników relatywnej przewagi RTA w polskim handlu produktami rolno-spożywczymi zarówno na rynku światowym, jak i na wszystkich analizowanych rynkach Polska nadal posiadała relatywne przewagi komparatywne w handlu tymi produktami. Były one przy tym wyraźnie wyższe w handlu z państwami UE-13 i krajami spoza UE niż z państwami UE-15.

W 2016 roku Polska posiadała przewagi komparatywne w szesnastu grupach produktów (działach HS), które stanowiły niespełna 73\% obrotów handlowych polskiego sektora rolno-spożywczego na rynku światowym. Jeśli chodzi o wymianę handlową z poszczególnymi grupami krajów, to udział takich produktów był dość zróżnicowany. Wahał się od około $61 \% \mathrm{w}$ obrotach handlowych z krajami spoza UE do $68 \%$ w handlu z państwami UE-15 i aż niespełna $80 \%$ w obrotach handlowych z państwami UE-13.

Najwyższe relatywne przewagi komparatywne w handlu na rynku światowym występowały w takich grupach produktów, jak: przetwory z mięsa i ryb, zboża, przetwory zbożowe i pieczywo cukiernicze, tytoń i wyroby tytoniowe, mięso i podroby, a także produkty mleczarskie, przetwory z owoców i warzyw oraz cukry i wyroby cukiernicze. Warto zauważyć, że były to na ogół produkty mające duże znaczenie dla polskiego przetwórstwa spożywczego.

W latach 2004-2016 wzrost przewag komparatywnych dotyczył grup produktów (dwunastu działów), których udział w 2016 roku w obrotach handlowych polskiego sektora rolno-spożywczego na rynku światowym wynosił ponad $47 \%$. Najbardziej wzrosły relatywne przewagi w handlu z państwami UE-13 - poprawa dotyczyła jedenastu działów HS, które miały udział w wymianie handlowej prowadzonej na tych rynkach wynoszący niespełna 49\%. W mniejszym stopniu poprawiły się względne przewagi w handlu z państwami UE-15 - wskaźniki RTA 
wzrosły w dziesięciu działach, których udział w obrotach handlowych z tymi krajami w 2016 roku wyniósł blisko 44\%. W handlu prowadzonym na rynku pozaunijnym wskaźniki RTA w analizowanym okresie zwiększyły się w jedenastu grupach produktów mających prawie $41 \%$ udziału w wymianie handlowej polskiego sektora rolno-spożywczego na tym rynku.

\subsection{Podsumowanie}

Analiza przewag komparatywnych w ujęciu B. Balassy (w tym ujęciu według wielu ekonomistów - raczej przewag konkurencyjnych) w handlu rolno-spożywczym Polski, w latach ubiegłych dokonywana na podstawie wskaźnika ujawnionych przewag komparatywnych RCA, w niniejszym opracowaniu przeprowadzona została na podstawie jego zmodyfikowanej formuły, tj. wskaźnika relatywnej przewagi RTA. Wskaźnik ten ma bardziej kompleksowy charakter, gdyż uwzględnia jednocześnie sytuację eksportową i importową kraju. Wyniki tego rachunku można traktować jako przybliżoną ocenę zdolności danego sektora do konkurowania w handlu międzynarodowym, a jednocześnie podstawę do oceny jego międzynarodowej pozycji konkurencyjnej (gdyż jest to wskaźnik konkurencyjności ex post, odnoszący się do jej pomiaru w przeszłości).

Przeprowadzone badania wykazały, że w okresie członkostwa w Unii Europejskiej Polska posiadała relatywne przewagi komparatywne zarówno w handlu rolno-spożywczym na rynku światowym, jak i w handlu na poszczególnych rynkach. Najwyższe przewagi, niemal w całym analizowanym okresie, polscy producenci żywności odnotowywali na rynku państw UE-13, a najniższe - nieprzerwanie na rynku państw UE-15. W analizowanym okresie poziom tych przewag we wszystkich przypadkach uległ jednak niewielkiemu obniżeniu. Produkty, w handlu którymi Polska posiadała w 2016 roku przewagi komparatywne, stanowiły niespełna $73 \%$ obrotów handlowych polskiego sektora rolno-spożywczego na rynku światowym. Nie wchodząc w szczegóły, z dużą dozą prawdopodobieństwa można stwierdzić, że polscy producenci żywności pozostawali konkurencyjni na rynku międzynarodowym.

Mimo niewątpliwych zalet teorii kosztów komparatywnych złożoność i turbulentność procesów występujących we współczesnej gospodarce powoduje, że kierunków i natężenia zmian strumieni handlu nie da się przedstawić tylko za pomocą jednej teorii handlu międzynarodowego. Próbując znaleźć odpowiedź na pytanie, dlaczego jeden kraj czy sektor gospodarki odnosi większe sukcesy w handlu zagranicznym i jest bardziej konkurencyjny od drugiego, należy poszukiwać coraz to nowych zmiennych objaśniających wymianę handlową i pozwalających oceniać konkurencyjność. 


\section{Ceny relatywne w polskim eksporcie produktów rolno-spożywczych do krajów Unii Europejskiej}

\subsection{Wprowadzenie}

Kraje Unii Europejskiej były i są największymi odbiorcami polskich produktów rolno-spożywczych. Po przystąpieniu Polski do UE nastąpił dynamiczny wzrost eksportu polskiej żywności na rynek unijny. W 2016 roku wartość tego eksportu wyniosła 20,6 mld USD i była ponad czteroipółkrotnie wyższa niż wartość eksportu w roku akcesji (2004) ${ }^{133}$. Tym samym, w 2016 roku na rynek Unii Europejskiej trafiło ponad $80 \%$ polskiej żywności sprzedanej za granicą. Systematycznie rosła też nadwyżka obrotów handlowych produktami rolno-spożywczymi Polski z UE, której wartość w 2016 roku wyniosła 8,5 mld USD.

Z badań przeprowadzonych w IERiGŻ-PIB wynika, iż w okresie członkostwa Polski w UE wyraźnie poprawiła się międzynarodowa konkurencyjność polskich producentów w wielu grupach produktów rolno-spożywczych. Wśród czynników poprawy konkurencyjności można wymienić wzrost produktywności i efektywności w rezultacie restrukturyzacji i modernizacji zakładów przetwórstwa spożywczego (przeprowadzonych w większości przed przystąpieniem Polski do UE i w pierwszym okresie po akcesji), wzrost koncentracji produkcji, napływ bezpośrednich inwestycji zagranicznych do polskiego przemysłu spożywczego, a przede wszystkim uzyskanie z dniem członkostwa dostępu przez polskich producentów do dużego unijnego rynku zbytu. Analizy konkurencyjności cenowo-jakościowej przeprowadzone metodą K. Aigingera wykazały, że podstawowymi instrumentami konkurowania w polskim handlu produktami rolno-spożywczymi (w tym z państwami UE) były niższe koszty produkcji, które umożliwiały oferowanie niższych cen produktów ${ }^{134}$. Potwierdziły to również analizy zróżnicowania cen żywności w Unii Europejskiej, przeprowadzone na

\footnotetext{
${ }^{133}$ W 2016 roku wartość polskiego eksportu rolno-spożywczego do państw UE-15 wyniosła 15,3 mld USD, a do państw UE-13 - 5,3 mld USD. Oznacza to odpowiednio ponad czterokrotny i czteroipółkrotny wzrost wartości eksportu w porównaniu z 2004 rokiem.

${ }^{134}$ Na przykład: I. Szczepaniak, Jakościowo-cenowe strategie konkurencji w polskim handlu produktami rolno-spożywczymi, [w:] I. Szczepaniak (red.), Monitoring i ocena konkurencyjności polskich producentów żywności (5). Synteza, seria „Program Wieloletni 2011-2014”, nr 115, IERiGŻ-PIB, Warszawa 2014, s. 67-81; I. Szczepaniak, Quality and price competition strategies in trade in agri-food products of Poland with the European Union, [w:] Ł. Ambroziak, M. Bułkowska, I. Szczepaniak, Assessment of the competitiveness of Polish food producers in the European Union, series „Multi-annual Programme 2011-2014”, nr 126.1, IAFE-NRI, Warsaw 2014, s. 86-101.
} 
podstawie danych Eurostatu ${ }^{135}$, czy też analizy wykonywane na podstawie statystyk poszczególnych krajów ${ }^{136}$.

W badaniu, którego wyniki przedstawiono w niniejszym rozdziale, podjęto próbę odpowiedzi na pytanie, czy ceny produktów rolno-spożywczych oferowanych przez polskich producentów żywności w krajach Unii Europejskiej były wyższe czy niższe od cen oferowanych przez dostawców z innych krajów. Tym samym badanie to pozwoli zweryfikować tezę, że międzynarodowa konkurencyjność polskiego sektora rolno-spożywczego w krajach Unii Europejskiej dotychczas opierała się bardziej na niższych kosztach produkcji, które umożliwiały oferowanie niższych cen produktów (strategia przywództwa kosztowego), niż na pozacenowych instrumentach konkurowania, w tym szeroko rozumianej jakości produktów (strategia zróżnicowania). Na potrzeby badania zastosowano jedną z metod badania konkurencyjności cenowo-jakościowej, tj. wskaźnik cen relatywnych w polskim eksporcie do krajów Unii Europejskiej.

Punktem wyjścia opracowania jest przedstawienie teoretycznych aspektów koncepcji wartości jednostkowych (unit values), utożsamianych z ceną, wykorzystywanej do badania jakości produktów w handlu międzynarodowym. Następnie szczegółowo omówiono metodę badania. Wykorzystując wskaźniki cen relatywnych w polskim eksporcie, w dalszej kolejności dokonano oceny konkurencyjności polskich producentów żywności w krajach UE wobec konkurentów z innych krajów.

\subsection{Koncepcja zastosowania wartości jednostkowych w badaniach jakości produktów}

Kwestia wartościowania jakości produktów w literaturze przedmiotu nie jest jednoznacznie określona. K. Aiginger określa produkt wysokiej jakości jako dobro, które posiada jedną lub wiele dodatkowych cech, które są na tyle cenione przez nabywców, że są oni gotowi zapłacić za to dobro wyższą cenę ${ }^{137}$. Na poprawę jakości produktu mogą wpływać różne czynniki wewnętrzne, m.in. wyko-

\footnotetext{
${ }^{135}$ I. Szczepaniak, Price advantages of Polish food producers in the European Union market, [w:] Ł. Ambroziak, M. Bułkowska, I. Szczepaniak, Assessment of the competitiveness of Polish food producers in the European Union, series „Multi-annual Programme 2011-2014”, nr 126.1, IAFE-NRI, Warsaw 2014, s. 102-115; I. Szczepaniak, Ceny żywności w Polsce i Unii Europejskiej w 2016 r., „Przemysł Spożywczy” 2017, nr 10, s. 2-6.

${ }^{136}$ J. Drożdż, Stan przewag cenowych na rynku wybranych produktów przetwórstwa spożywczego, [w:] I. Szczepaniak (red.), Monitoring i ocena konkurencyjności polskich producentów żywności (3). Potencjat konkurencyjny - wybrane elementy, seria „Program Wieloletni 2011-2014", nr 73, IERiGŻ-PIB, Warszawa 2013, s. 24-41.

${ }^{137}$ K. Aiginger, Europe's Position in Quality Competition, [w:] Competitiveness Report 2000, European Commission, Brussels 2000.
} 
rzystywanie w procesie produkcji wysoko wykwalifikowanej siły roboczej, nowoczesnych maszyn i urządzeń, lepszych jakościowo materiałów, dobra organizacja pracy, wysokie nakłady na badania i rozwój, wzrost innowacyjności poprzez imitację efektywnych technik i procesów, skuteczny marketing, a także czynniki zewnętrzne, m.in. polityka gospodarcza państwa ${ }^{138}$. Wysoką jakość produktu można traktować jako rodzaj przewagi konkurencyjnej i instrument konkurowania, a przy porównaniu z produktami oferowanymi przez konkurentów - również jako miernik pozycji konkurencyjnej ${ }^{139}$. K. Aiginger definiuje pojęcie konkurowania jakością jako środowisko konkurowania, w którym poprawa jakości powoduje wzrost skłonności do nabywania produktów, w przeciwieństwie do sytuacji konkurowania niższą ceną. Z poprawą jakości wiąże się bowiem nierozłącznie wzrost ceny oferowanego nabywcom produktu ${ }^{140}$. Według D. Greenawaya, R. Hine'a i C. Milnera, przy założeniu doskonałej informacji, dobro sprzedane po wyższej cenie musi być wyższej jakości niż dobro tańsze ${ }^{141}$. Co więcej, J. Stiglitz uważa, że nawet w warunkach niedoskonałej informacji ceny często odzwierciedlają różnice $\mathrm{w}$ jakości ${ }^{142}$.

Jak zauważa E. Duchnowska, strategia konkurowania ceną, budowana w oparciu o przewagę kosztową, zależy przede wszystkim od poziomu i zmian jednostkowych kosztów pracy oraz nominalnego kursu walutowego. Z kolei strategia konkurowania jakością (zwana również strategią różnicowania), opierająca się na skutecznym konkurowaniu produktami charakteryzującymi się swoistymi właściwościami, odróżniającymi je od konkurentów, jest głównie związana z nowoczesnością i innowacyjnością produktów ${ }^{143}$.

Podstawą metody analizy handlu z wykorzystaniem średnich cen są wartości jednostkowe (unit value) w eksporcie i imporcie, definiowane jako relacje wartości strumienia handlu i ilości w jednostkach fizycznych (zazwyczaj w kilogramach). K. Aiginger zauważa, że wartości jednostkowe mogą być z jednej strony miernikiem produktywności i jakości produktu, a z drugiej - jego ceną

\footnotetext{
${ }^{138}$ Ł. Ambroziak, Konkurencyjność cenowo-jakościowa polskich producentów żywności na rynku niemieckim, „Zeszyty Naukowe SGGW w Warszawie. Problemy Rolnictwa Światowego” 2016, nr 16(31), z. 1, s. 7-24.

${ }^{139}$ E. Duchnowska, Konkurencyjność cenowo-jakościowa polskiego handlu zagranicznego, [w:] K. Marczewski (red.), Ceny w handlu zagranicznym Polski. Aspekty makro- i mikroekonomiczne, Dom Wydawniczy ELIPSA, Warszawa 2014.

${ }^{140} \mathrm{~K}$. Aiginger, Europe's Position..., op. cit.

${ }^{141}$ D. Greenaway, R. Hine, C. Milner, Country specific factors and the pattern of horizontal and vertical intra-industry trade in the United Kingdom, „Weltwirtschaftliches Archiv” 1994, nr 130(1), s. 77-100.

142 J.E. Stiglitz, The causes and consequences of the dependence of quality price, „The Journal of Economic Literature" 1987, nr 25, s. 1-48.

${ }^{143}$ E. Duchnowska, Konkurencyjność cenowo-jakościowa..., op. cit.
} 
i kosztem. W największym stopniu odzwierciedlają one szeroko rozumianą jakość produktu na najniższym poziomie agregacji danych handlowych ${ }^{144}$. E. Duchnowska uważa, że ma to szczególne znaczenie w przypadku produktów heterogenicznych, gdyż wartość przyjmowana do wyliczenia ceny wagowej uwzględnia wszystkie cechy jakościowe produktu - fizycznie mierzalne i niemierzalne, np.: pojemność, wielkość, prędkość, trwałość, niezawodność, wzornictwo itp. ${ }^{145}$ Wzrost wartości jednostkowej nie zawsze może być jednak efektem poprawy jakości produktu. Może on też wynikać ze zmiany struktury asortymentowej i geograficznej strumieni handlu zagranicznego ${ }^{146}$, silnego wzrostu popytu na rynku zagranicznym czy ograniczenia podaży przez konkurentów, przy założeniu braku spadku udziału w rynku ${ }^{147}$. Ponadto nawet samo wyliczanie wartości jednostkowych może budzić wątpliwości natury metodologicznej, m.in. wartość eksportu i importu jest na granicy rejestrowana odmiennie (eksport według fob, a import według cif), występują liczne braki w danych wagowych sprzedawanych za granicę produktów. Mając na uwadze ww. problemy, należy do uzyskanych wyników podchodzić z ostrożnością.

Mimo trudności interpretacyjnych, analiza cen w handlu zagranicznym dość często wykorzystywana jest w badaniach konkurencyjności krajów, głównie na poziomie sektorów (branż). K. Aiginger ${ }^{148}$ badał konkurencyjność cenowo-jakościową z wykorzystaniem metody opartej na relacji średnich cen w eksporcie i imporcie (zwanej również metodą K. Aigingera) w handlu zagranicznym Niemiec, krajów Europy Środkowej i Wschodniej ${ }^{149}$ oraz państw Unii Europejskiej $^{150}$. Metodę K. Aigingera do badania handlu krajów Europy Środkowej i Wschodniej wykorzystali także J. Nielsen ${ }^{151}$ oraz U. Dulleck i in. ${ }^{152}$, a do badania

\footnotetext{
${ }^{144} \mathrm{~K}$. Aiginger, The use of unit values to discriminate between price and quality competition, „Cambridge Journal of Economics” 1997, nr 21, s. 571-592.

${ }^{145}$ E. Duchnowska, Konkurencyjność cenowo-jakościowa..., op. cit.

${ }^{146}$ W. Burzyński, K. Marczewski, J. Wojnar, Analiza cen osiaganych przez eksporterów polskich i konkurentów z krajów Unii Europejskiej na rynku niemieckim w latach 1992-1995, [w:] Zagraniczna polityka gospodarcza Polski 1996-1997, IKCHZ, Warszawa 1997.

${ }_{147}$ J.W. Bossak, Konkurencyjność gospodarki Polski a proces integracji europejskiej i rozwoju gospodarki opartej na wiedzy, [w:] T. Michalski i K. Piech (red.), Konkurencyjność Polski $w$ procesie pogtębiania integracji europejskiej i budowy gospodarki opartej na wiedzy, Oficyna Wydawnicza SGH, Warszawa 2008.

${ }^{148} \mathrm{~K}$. Aiginger, The use of unit values..., op. cit.

${ }^{149} \mathrm{~K}$. Aiginger, Unit values to signal the quality position of CEECs, [w:] Y. Wolfmayr (red.), The Competitiveness of Transition Countries, OECD Publishing, 1998, s. 93-121.

${ }^{150} \mathrm{~K}$. Aiginger, Europe's Position..., op. cit.

${ }^{151} \mathrm{~J}$. Nielsen, Price-quality competition in the exports of the Central and Eastern European Countries, „Intereconomics” 2000, nr 35(2), s. 94-101.

${ }^{152}$ U. Dulleck i in., Dimensions of Quality Upgrading in CEECs, wiiw Working Paper, 2004, nr 29, Wien.
} 
handlu Polski: M. Olczyk ${ }^{153}$, W. Burzyński ${ }^{154}$, Ł. Ambroziak ${ }^{155}$ oraz E. Duchnow$\mathrm{ska}^{156}$. Metoda K. Aigingera była również stosowana w analizach konkurencyjności handlu rolno-spożywczego Rumunii ${ }^{157}$ oraz Polski ${ }^{158}$. Z kolei W. Burzyński, K. Marczewski i J. Wojnar ${ }^{159}$ oraz W. Burzyński i L. Jasiński ${ }^{160}$ analizowali ceny osiągane przez eksporterów polskich na rynku niemieckim wobec konkurentów $\mathrm{z}$ innych krajów, a E. Duchnowska ${ }^{161}$ ceny w polskim eksporcie na rynek państw UE-15 i UE-13 względem wybranych konkurentów z innych krajów. Ł. Ambroziak $^{162}$ analizował natomiast ceny relatywne $\mathrm{w}$ polskim eksporcie rolno-spożywczym na rynku niemieckim wobec konkurentów z innych krajów.

\subsection{Metoda badania}

W opracowaniu wykorzystano jedną z metod badania konkurencyjności cenowo-jakościowej, tj. wskaźnik cen relatywnych w polskim eksporcie rolno-

\footnotetext{
${ }^{153}$ M. Olczyk, Konkurencyjność. Teoria i praktyka, Wydawnictwa Fachowe CeDeWu.PL, Warszawa 2008.

${ }^{154}$ W. Burzyński, Analiza konkurencyjności polskiego eksportu do Unii Europejskiej przeprowadzona metoda jakościowo-cenowa, [w:] J. Kotyński (red.), Korzyści i koszty członkostwa Polski w Unii Europejskiej, t. I, IKCHZ, Warszawa 2000.

${ }^{155}$ Ł. Ambroziak, Kierunki specjalizacji w handlu zagranicznym Polski z Unia Europejska, [w:] E. Kaliszuk i K. Marczewski (red.), Wpływ członkostwa w Unii Europejskiej na stosunki gospodarcze Polski z zagranica, IBRKK, Warszawa 2009.

${ }_{156}$ E. Duchnowska, Konkurencyjność cenowo-jakościowa..., op. cit.

${ }^{157}$ C. Gavrilescu, D.-M. Voicilaş, Changes in the Romanian agrifood trade competitiveness in the post-accession period, „Management Theory and Studies for Rural Business and Infrastructure Development" 2014, vol. 36, nr 4, s. 823-834.

${ }^{158}$ Ł. Ambroziak, I. Szczepaniak, Jakościowo-cenowe wskaźniki konkurencyjności w handlu produktami rolno-spożywczymi Polski, [w:] I. Szczepaniak (red.), Monitoring i ocena konkurencyjności polskich producentów żywności (2), seria „Program Wieloletni 2011-2014”, nr 40, IERiGŻ-PIB, Warszawa 2012, s. 71-90; I. Szczepaniak, Jakościowo-cenowe strategie konkurencji..., op. cit.; I. Szczepaniak, M. Tereszczuk, The improvement in the international competitiveness of the Polish food sector and its support with public funds during Poland's membership in the EU, [w:] A. Sorrentino, S. Severini i C. Cicatiello (red.), The Value of Food. Internazionalization, competition and local development in agro-food systems, Proceedings of the 52nd SIDEA Conference, Rome/Viterbo, September 17th - 19th, 2015, Rivista di Economia Agraria, vol. 71, nr 1 (Suppl.) - 2016, s. 134-143; Ł. Ambroziak, Price and quality competition strategies of Polish agri-food products exporters, [w:] T. Löster i T. Pavelka (red.), The 7th International Days of Statistics and Economics. Conference Proceedings, September 19-21, 2013, Prague, Libuše Macáková, Melandrium, 2013, s. 22-32.

${ }^{159}$ W. Burzyński, K. Marczewski, J. Wojnar, Analiza cen..., op. cit.

${ }^{160}$ W. Burzyński, L. Jasiński, Analiza poziomu cen osiaganego przez eksporterów polskich na rynku niemieckim w latach 1992-1994, [w:] Polska polityka handlu zagranicznego 1995-1996, IKCHZ, Warszawa 1996.

${ }^{161}$ E. Duchnowska, Konkurencyjność cenowo-jakościowa..., op. cit.

${ }^{162}$ Ł. Ambroziak, Konkurencyjność cenowo-jakościowa..., op. cit.
} 
-spożywczym na rynek Unii Europejskiej. Metoda ta pozwala określić, czy ceny oferowane przez polskich producentów żywności na rynku unijnym są wyższe bądź niższe od cen oferowanych przez konkurentów z innych krajów.

Dla zachowania porównywalności średnich cen w eksporcie wszystkich krajów świata do poszczególnych krajów UE posłużono się danymi o imporcie krajów UE. Przyjęto bowiem, że nie ma różnic w statystykach lustrzanych. Dla przykładu, wartość polskiego eksportu do Niemiec jest równa wartości niemieckiego importu z Polski. Założenie to z góry nie jest jednak spełnione, chociażby z uwagi na różny sposób ujmowania wartości strumieni eksportu i importu (fob versus cif). Punktem wyjścia opracowywania bazy danych były zatem bilateralne strumienie importu wszystkich krajów UE (z wyjątkiem Polski) na poziomie sześciocyfrowym klasyfikacji HS. Dane te posłużyły do obliczenia średnich cen w imporcie UE z Polski oraz z pozostałych krajów-partnerów handlowych (zwanych również konkurentami) na poziomie sześciocyfrowym klasyfikacji HS. Obliczenia te poprzedziły działania służące eliminacji tzw. obserwacji odstających (outliers) mogących zaburzyć otrzymane wyniki badania. W tym celu dokonano kilku zabiegów, zalecanych przez literaturę przedmiotu ${ }^{163}$. Po pierwsze, usunięto obserwacje, dla których wartość importu wyniosła poniżej 1 tys. USD, brak było danych dotyczących wagi importowanych produktów, bądź waga ta była niższa niż $50 \mathrm{~kg}$. Po drugie, dla danego kraju handlującego, danej grupy produktów (na poziomie sześciocyfrowym HS) i danego roku wyeliminowano obserwacje dotyczące importu z poszczególnych krajów, dla których wartości jednostkowe wyraźnie odstawały w porównaniu ze średnią dla wszystkich partnerów. Po trzecie, dla danej pary krajów i danej grupy produktów (na poziomie sześciocyfrowym HS) wyeliminowano te obserwacje, dla których wartości jednostkowe $\mathrm{w}$ imporcie w danym roku istotnie różniły się od wartości jednostkowych w roku poprzednim bądź następnym.

Średnie ceny w eksporcie ze wszystkich krajów-konkurentów łącznie (z wyjątkiem Polski) do poszczególnych krajów UE na poziomie sześciocyfrowym klasyfikacji HS obliczono według wzoru ${ }^{164}$ :

$$
U V_{i}^{k o n k, m}=\sum_{j=1}^{k}\left(\frac{V_{i}^{j m}}{Q_{i}^{j m}}\right) \cdot\left(\frac{V_{i}^{j m}}{\sum_{j=1}^{k} V_{i}^{j m}}\right)
$$

\footnotetext{
${ }^{163}$ Więcej informacji o metodach pozbywania się obserwacji odstających można znaleźć w następujących publikacjach: Export and Import Price Index Manual. Theory and Practice, IMF, 2009; R. Jansen, Calculation of external trade indices based on unit values - training module, UN DESA, Statistics Division, 2009; A. Berthou, Ch. Emlinger, The Trade Unit Values Database, CEPII Working Paper, nr 2011-10.

${ }^{164}$ Opracowanie własne na podstawie: U. Dulleck i in., Dimensions of Quality..., op. cit., s. 8-10.
} 
gdzie:

$U V_{i}^{k o n k, m}$ - średnia cena wagowa w eksporcie produktu $i$ przez wszystkie krajekonkurentów (z wyjątkiem Polski) do kraju $m$ (poszczególne kraje UE z wyjątkiem Polski),

$V_{i}^{j m}, Q_{i}^{j m}$-odpowiednio wartość i wolumen eksportu produktu $i$ przez krajkonkurenta $j$ do kraju $m$,

$i$ - produkt na poziomie sześciocyfrowym klasyfikacji HS,

$j$ - kraj-konkurent,

$k$ - liczba krajów-konkurentów,

$m$ - poszczególne kraje UE, z wyjątkiem Polski.

Wskaźniki cen relatywnych w eksporcie rolno-spożywczym do poszczególnych krajów UE obliczono natomiast według następującego wzoru ${ }^{165}$ :

$$
R C_{z}^{k o n k, m}=\frac{\sum_{i=1}^{n} U V_{i}^{k o n k, m} \cdot\left(\frac{V_{i}^{\text {PLm }}}{\sum_{i=1}^{n} V_{i}^{\text {PLm }}}\right)}{\sum_{i=1}^{n}\left(\frac{V_{i}^{\text {PLm }}}{Q_{i}^{\text {PLm }}}\right) \cdot\left(\frac{V_{i}^{\text {PLm }}}{\sum_{i=1}^{n} V_{i}^{\text {PLm }}}\right)}
$$

gdzie:

$R C_{z}^{k o n k, m}$ - wskaźnik relacji średnich cen wagowych w polskim eksporcie i eksporcie konkurentów z pozostałych krajów świata na rynek $m$ w grupie produktów $z$ (tutaj: działy HS bądź handel rolno-spożywczy ogółem, tj. działy HS01-HS24),

$U V_{i}^{k o n k, m}$ - średnia cena wagowa w eksporcie produktu $i$ wszystkich krajów (z wyjątkiem Polski) na rynek $m$,

$V_{i}^{P L m}, Q_{i}^{P L m}$ - odpowiednio wartość i wolumen eksportu Polski $i$-tego produktu na rynek $m$,

$n$ - liczba produktów w grupie produktów $z$.

Analogicznie obliczono wskaźniki cen relatywnych w polskim eksporcie rolno-spożywczym ogółem oraz według działów do państw UE-15 oraz UE-13.

${ }^{165}$ Opracowanie własne na podstawie: E. Duchnowska, Konkurencyjność cenowo-jakościowa..., op. cit., s. 87. 
Zwraca uwagę fakt, że ceny krajów-konkurentów w polskim eksporcie rolno-spożywczym do danego kraju UE na poziomie działu HS bądź ogółem (licznik we wzorze) uzyskano poprzez zważenie ich cen na poziomie sześciocyfrowym klasyfikacji HS strukturą wartościową polskiego eksportu danego działu bądź eksportu rolno-spożywczego ogółem na rynek danego kraju. Innymi słowy obliczono ceny krajów-konkurentów w eksporcie do danego kraju, przy założeniu, że struktura jego eksportu była taka sama jak polskiego eksportu.

Wskaźniki RC > 1 oznaczały, że średnie ceny w eksporcie na rynek danego kraju UE z krajów-konkurentów były wyższe niż w polskim eksporcie, co wskazuje na posiadanie przewag cenowych przez polskich eksporterów na rynku tego kraju. W sytuacji, gdy $\mathrm{RC}<1$ to ceny $\mathrm{w}$ polskim eksporcie na rynek danego kraju UE były wyższe niż w eksporcie krajów-konkurentów, a tym samym polscy eksporterzy konkurowali na tym rynku jakością oferowanych produktów.

Badanie przeprowadzono w oparciu o dane dotyczące importu wszystkich krajów UE z poszczególnych krajów-partnerów handlowych na poziomie sześciocyfrowym klasyfikacji HS, wyrażone w USD i pochodzące z bazy WITS-Comtrade. Analizą objęto produkty rolno-spożywcze ogółem oraz w podziale na działy HS. Pod pojęciem produkty rolno-spożywcze rozumiano działy 01-24 klasyfikacji HS. Badaniem objęto lata 2004-2016, jednak w celu wyeliminowania przypadkowych zmian obrotów handlowych mających wpływ na otrzymane wyniki oceny analizę wskaźników przeprowadzono w okresach dwu- i trzyletnich ${ }^{166}$.

\subsection{Analiza cen relatywnych w polskim eksporcie do Unii Europejskiej}

\subsubsection{Ceny relatywne w eksporcie do państw UE-15 i UE-13}

W latach 2004-2016 Polska miała w eksporcie rolno-spożywczym zarówno do państw UE-15, jak i UE-13 cenowe przewagi konkurencyjne nad pozostałymi konkurentami. Oznacza to, że ceny oferowane przez polskich producentów żywności na rynkach tych krajów były niższe niż ceny konkurentów z innych krajów. W badanym okresie wyższe wskaźniki cen relatywnych notowano w eksporcie do nowych państw członkowskich UE niż do krajów „Piętnastki”. W eksporcie do tej pierwszej grupy państw wskaźniki cen relatywnych cechowały się również większą zmiennością.

\footnotetext{
${ }^{166}$ Wyszczególniono następujące okresy: 2004-2006 - pierwsze trzy lata członkostwa Polski w UE, 2007-2008 - dwa lata poprzedzające globalny kryzys finansowo-gospodarczy, 2009-2011 - okres kryzysu finansowo-gospodarczego oraz kryzysu zadłużeniowego w strefie euro, 2012-2013 - okres spowolnienia gospodarczego w UE, 2014-2016 - ostatnie trzy lata objęte analizą, w czasie których nastąpiło ożywienie gospodarcze w UE.
} 
Z wyjątkiem lat 2012-2013 oraz 2004 średnie ceny w polskim eksporcie rolno-spożywczym do krajów „Piętnastki” były o około 20-26\% niższe od cen pozostałych dostawców do tych krajów. Największe przewagi cenowe na rynkach państw UE-15 polscy producenci żywności mieli w 2004 roku, kiedy to wskaźnik RC wyniósł 1,34 (wykres 3.1). Oznacza to, że za jednostkę wolumenu eksportowanego do państw UE-15 Polska otrzymywała wartość jednostkową niższą o $34 \%$ niż pozostali światowi konkurenci. Innymi słowy, aby uzyskać tę samą wartość wyrażoną w dolarach amerykańskich w eksporcie, Polska musiała wywieźć do krajów „Piętnastki” 1,34 ton produktów, podczas gdy pozostali konkurenci zaledwie 1 tonę. W latach 2005-2007 osłabiły się przewagi cenowe w polskim eksporcie rolno-spożywczym do państw UE-15 wobec światowych konkurentów (wskaźniki RC ukształtowały się na poziomie nieco powyżej 1,20). Oznacza to, że w coraz mniejszym stopniu polskie firmy konkurowały na tym rynku niższą ceną sprzedawanych produktów. W latach 2008-2010 wskaźniki RC wzrosły i przekroczyły poziom 1,25 , a zatem w okresie światowego kryzysu finansowo-gospodarczego większego znaczenia nabrało konkurowanie niższą ceną oferowanych produktów. Lata 2011-2014 to okres ponownego osłabienia przewag cenowych polskich eksporterów na rynkach państw UE-15 wobec pozostałych konkurentów. W latach 2015-2016 wskaźniki RC ponownie wzrosły, do poziomu 1,25 w 2016 roku. Były one jednak w dalszym ciągu niższe niż w roku akcesji (o 0,09 pkt).

Wykres 3.1. Wskaźniki cen relatywnych RC w polskim eksporcie rolno-spożywczym do państw UE-15 oraz UE-13

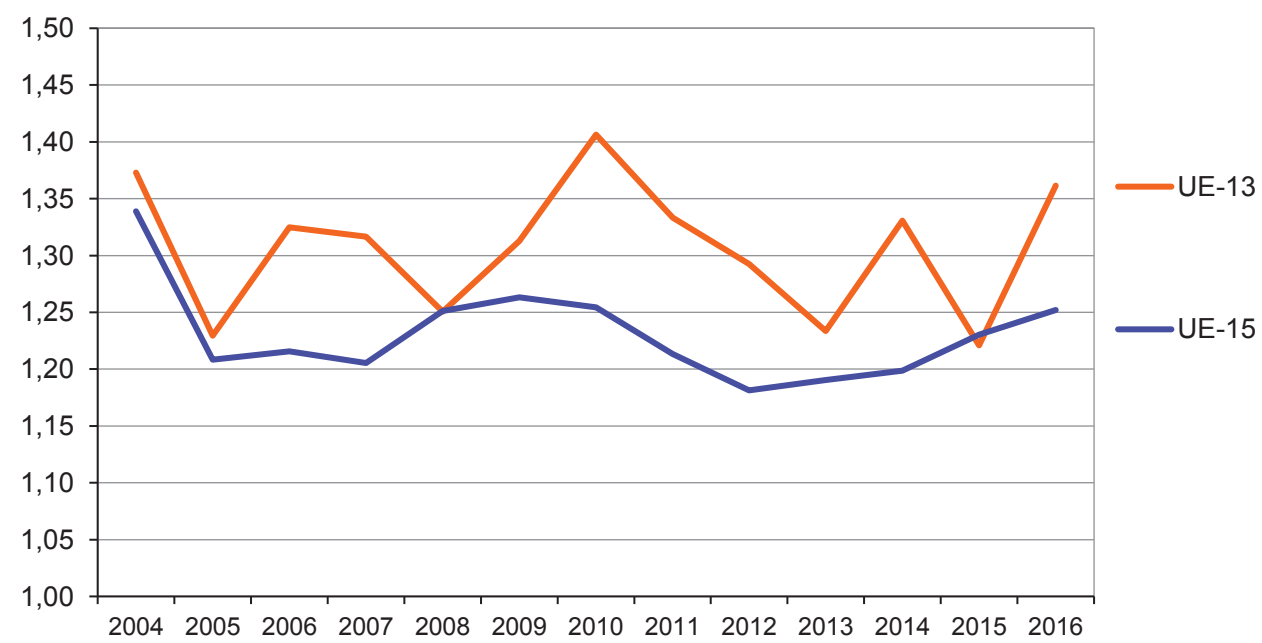

Źródto: obliczenia wtasne na podstawie danych WITS-Comtrade. 
W eksporcie rolno-spożywczym Polski do nowych państw członkowskich UE brak było wyraźnego trendu w zmianach wskaźników cen relatywnych. Odnotowano duże wahania wartości tych wskaźników. Najsilniejsze przewagi cenowe na rynkach państw UE-13 wobec pozostałych konkurentów polscy producenci żywności mieli w latach 2004, 2010 oraz 2016. Wówczas wskaźniki RC przekraczały wartość 1,35 . Wskaźniki poniżej 1,25 odnotowano natomiast w latach 2005, 2008, 2013 oraz 2015. W 2016 roku średnie ceny w polskim eksporcie do państw UE-13 były o $36 \%$ niższe od cen pozostałych dostawców. Oznacza to, że w całym analizowanym okresie Polska konkurowała na rynkach państw UE-13 niższymi cenami sprzedawanych produktów.

\subsubsection{Ceny relatywne w eksporcie do poszczególnych państw UE}

Ceny w polskim eksporcie rolno-spożywczym do poszczególnych państw Unii Europejskiej w relacji do cen oferowanych przez konkurentów niekiedy istotnie się różniły. W pierwszych trzech latach po przystąpieniu Polski do UE (2004-2006) polscy producenci żywności mieli przewagi jakościowe na rynkach trzech krajów - Portugalii, Luksemburga i Irlandii (tabela 3.1 i wykres 3.2). Oznacza to, że ceny w polskim eksporcie rolno-spożywczym do tych krajów były niższe niż ceny w eksporcie pozostałych krajów-konkurentów. Wskazuje to także, że polscy producenci konkurowali na tych rynkach jakością sprzedawanych produktów. Przewagi jakościowe były jednak słabe, gdyż odnotowano zaledwie kilkuprocentowe różnice między cenami produktów oferowanymi przez polskich i pozostałych producentów żywności.

W eksporcie rolno-spożywczym do pozostałych krajów UE Polska miała w latach 2004-2006 przewagi cenowe wobec pozostałych konkurentów na rynkach tych krajów. Najsilniejsze przewagi odnotowano w eksporcie na Litwę, do Szwecji i Czech. Ceny produktów oferowanych na tych rynkach przez konkurentów z innych krajów były o 40-50\% wyższe niż ceny produktów rolno-spożywczych oferowanych przez polskich producentów. W eksporcie do Niemiec, na Słowację, do Hiszpanii i Słowenii różnice te oscylowały w granicach 30-40\%. Do krajów, w eksporcie do których ceny żywności sprzedawanej przez konkurentów były w latach 2004-2006 wyższe o 20-30\% niż ceny polskiej żywności należały: Węgry, Holandia, Łotwa, Dania, Austria, Bułgaria, Cypr i Wielka Brytania. Słabe cenowe przewagi konkurencyjne polscy producenci żywności mieli natomiast w: Belgii, Francji, Finlandii, Grecji, Włoszech, Rumunii, Estonii i na Malcie. W eksporcie do Chorwacji średnie ceny produktów oferowanych przez konkurentów były zaledwie o 4\% wyższe niż ceny produktów oferowanych przez polskie firmy. 
Tabela 3.1. Wskaźniki cen relatywnych RC w polskim eksporcie rolno-spożywczym do poszczególnych państw UE wobec konkurentów z innych krajów

\begin{tabular}{|c|c|c|c|c|c|c|c|c|}
\hline & \multirow[t]{2}{*}{ Kraj } & $\begin{array}{l}2004- \\
-2006\end{array}$ & $\begin{array}{l}2007- \\
-2008\end{array}$ & $\begin{array}{l}2009- \\
-2010\end{array}$ & $\begin{array}{l}2011- \\
-2013\end{array}$ & $\begin{array}{l}2014- \\
-2016\end{array}$ & \multirow{2}{*}{$\begin{array}{l}\text { Zmiana wartości } \\
\text { wskaźnika RC } \\
\text { 2014-2016/ } \\
\text { 2004-2006 } \\
\text { (w pkt) }\end{array}$} & \multirow{2}{*}{$\begin{array}{c}\text { Udział danego } \\
\text { państwa w eksporcie } \\
\text { rolno-spożywczym } \\
\text { Polski } \\
\text { w latach 2014-2016 } \\
\text { (w proc.) }\end{array}$} \\
\hline & & \multicolumn{5}{|c|}{ wartość wskaźnika RC } & & \\
\hline \multirow{15}{*}{$\frac{n}{\frac{1}{b}}$} & Niemcy & 1,37 & 1,30 & 1,38 & 1,28 & 1,29 & $-0,08$ & 22,6 \\
\hline & Wielka Brytania & 1,21 & 1,12 & 1,30 & 1,43 & 1,62 & 0,41 & 8,4 \\
\hline & Francja & 1,15 & 1,13 & 1,13 & 1,21 & 1,20 & 0,05 & 6,1 \\
\hline & \begin{tabular}{|l|} 
Włochy \\
\end{tabular} & 1,15 & 1,15 & 1,08 & 0,99 & 0,99 & $-0,16$ & 5,7 \\
\hline & Holandia & 1,27 & 1,25 & 1,29 & 1,22 & 1,35 & 0,08 & 5,4 \\
\hline & Hiszpania & 1,31 & 1,67 & 1,22 & 1,05 & 1,11 & $-0,20$ & 2,2 \\
\hline & Belgia & 1,12 & 1,00 & 1,04 & 1,07 & 1,03 & $-0,09$ & 2,1 \\
\hline & Dania & 1,26 & 1,38 & 1,77 & 1,49 & 1,25 & $-0,01$ & 2,0 \\
\hline & Szwecja & 1,46 & 1,17 & 1,26 & 1,28 & 1,33 & $-0,13$ & 1,6 \\
\hline & Austria & 1,25 & 1,10 & 1,34 & 1,09 & 1,14 & $-0,11$ & 1,6 \\
\hline & Irlandia & 0,96 & 1,23 & 1,18 & 1,14 & 1,38 & 0,42 & 0,8 \\
\hline & Grecja & 1,15 & 1,26 & 1,17 & 1,24 & 1,27 & 0,12 & 0,7 \\
\hline & Finlandia & 1,14 & 1,28 & 1,56 & 1,34 & 1,36 & 0,22 & 0,5 \\
\hline & Portugalia & 0,91 & 1,00 & 0,89 & 1,05 & 1,09 & 0,18 & 0,4 \\
\hline & Luksemburg & 0,92 & 0,94 & 1,00 & 1,04 & 0,95 & 0,03 & 0,0 \\
\hline \multirow{12}{*}{$\begin{array}{l}\frac{m}{1} \\
\frac{1}{b}\end{array}$} & Czechy & 1,40 & 1,39 & 1,46 & 1,41 & 1,49 & 0,09 & 6,6 \\
\hline & Słowacja & 1,33 & 1,32 & 1,43 & 1,36 & 1,29 & $-0,04$ & 3,1 \\
\hline & Węgry & 1,28 & 1,27 & 1,50 & 1,39 & 1,29 & 0,01 & 2,6 \\
\hline & Litwa & 1,47 & 1,45 & 1,38 & 1,27 & 1,20 & $-0,27$ & 2,2 \\
\hline & Rumunia & 1,19 & 1,15 & 1,36 & 1,22 & 1,42 & 0,23 & 2,2 \\
\hline & Lotwa & 1,27 & 1,13 & 0,98 & 0,97 & 1,18 & $-0,09$ & 1,2 \\
\hline & Bułgaria & 1,26 & 1,14 & 1,12 & 1,17 & 1,28 & 0,02 & 1,1 \\
\hline & Chorwacja & 1,04 & 1,16 & 1,50 & 1,20 & 1,01 & $-0,03$ & 0,7 \\
\hline & Estonia & 1,13 & 1,30 & 1,23 & 1,19 & 1,23 & 0,10 & 0,6 \\
\hline & Słowenia & 1,31 & 1,21 & 1,14 & 1,21 & 1,17 & $-0,14$ & 0,4 \\
\hline & Cypr & 1,21 & 1,03 & 0,91 & 0,94 & 1,02 & $-0,19$ & 0,2 \\
\hline & Malta & 1,15 & 1,07 & 1,49 & 1,15 & 0,75 & $-0,40$ & 0,0 \\
\hline
\end{tabular}

Źródto: obliczenia własne na podstawie danych WITS-Comtrade.

W okresie członkostwa Polski w UE przewagi cenowe polskich producentów żywności wobec pozostałych konkurentów osłabiły się (spadek wskaźnika RC) w eksporcie do trzynastu państw członkowskich UE. Wskaźniki RC najbardziej zmalały w eksporcie: na Maltę (o 0,40 pkt), Litwę (o 0,27 pkt), do Hiszpanii (o 0,20 pkt), na Cypr (o 0,19 pkt), do Włoch (o 0,16 pkt), Słowenii (o 0,14 pkt), Szwecji (o 0,13 pkt) oraz Austrii (o 0,11 pkt). W eksporcie na Łotwę, do Belgii i Niemiec wskaźniki RC zmniejszyły się o mniej niż 0,10 pkt, a w eksporcie na Słowację, do Chorwacji i Danii - o mniej niż 0,05 pkt. Wyraźne umocnienie przewag cenowych wobec konkurentów (wzrost wskaźników RC) odnotowano 
w polskim eksporcie rolno-spożywczym do Irlandii (o 0,42 pkt) i Wielkiej Brytanii (o $0,41 \mathrm{pkt}$ ). W pewnym stopniu przyczynić się do tego mogła duża skala emigracji Polaków do tych krajów po przystąpieniu Polski do Unii Europejskiej ${ }^{167}$. Nabywając produkty żywnościowe, kierowali się oni prawdopodobnie bardziej ich ceną i przyzwyczajeniami niż jakością. O nieco ponad 0,20 pkt wzrosły w okresie członkostwa wskaźniki RC w polskim eksporcie żywności do Finlandii i Rumunii, a o ponad 0,10 pkt - w eksporcie do Portugalii, Grecji i Estonii. W eksporcie do pozostałych krajów, tj.: Czech, Francji, Holandii, Belgii, Luksemburga, Bułgarii wskaźniki RC wzrosły o mniej niż 0,10 pkt, a w eksporcie do Bułgarii i na Węgry praktycznie się nie zmieniły.

Wykres 3.2. Wskaźniki cen relatywnych $\mathrm{RC}$ w polskim eksporcie rolno-spożywczym do poszczególnych państw UE wobec konkurentów z innych krajów

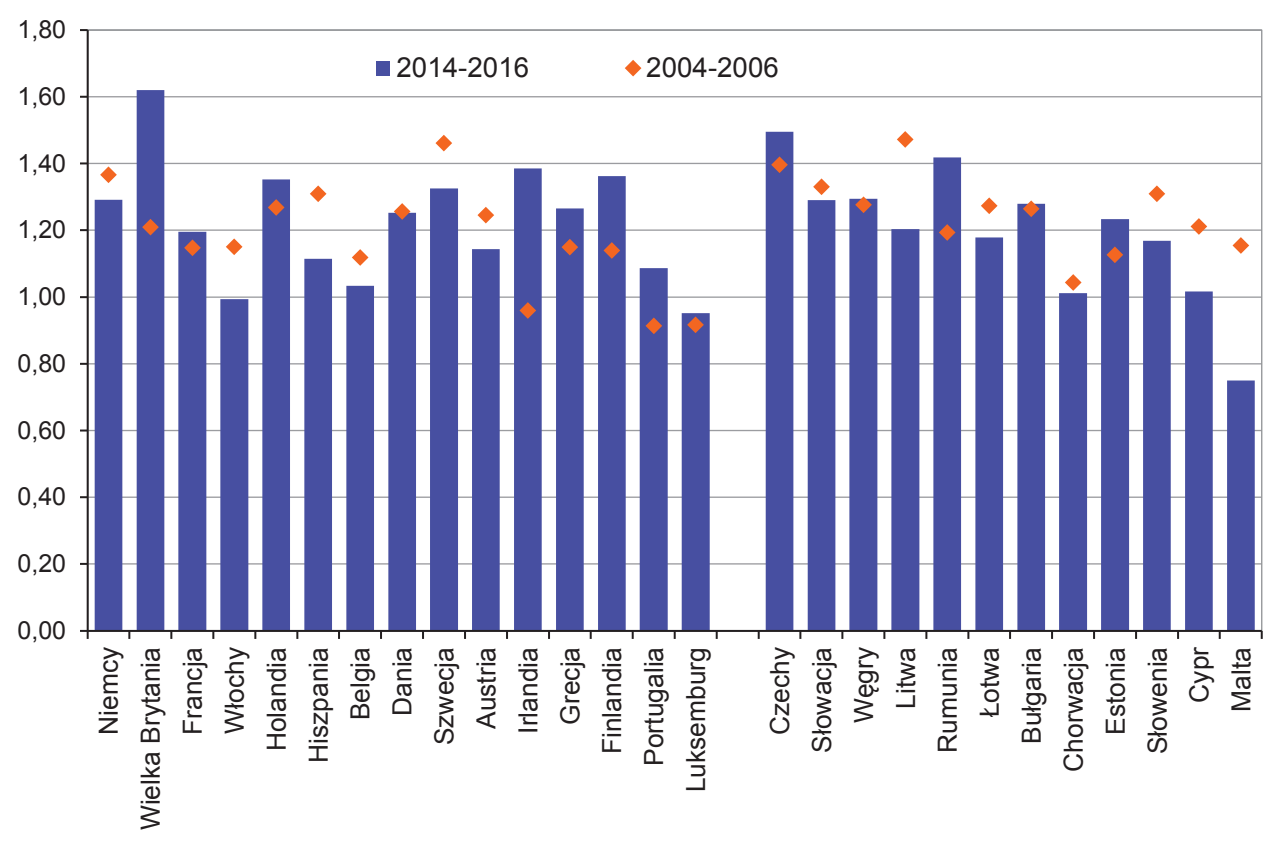

Źródto: obliczenia wtasne na podstawie danych WITS-Comtrade.

W latach 2014-2016 Polska miała przewagi jakościowe wobec konkurentów w eksporcie rolno-spożywczym do zaledwie trzech krajów, tj. na Maltę, do Luksemburga i Włoch. Z wyjątkiem Malty przewagi te były niewielkie - średnia

\footnotetext{
${ }^{167}$ Według danych GUS, na koniec 2016 roku w Wielkiej Brytanii czasowo przebywało 788 tys. Polaków, a w Irlandii - 112 tys. Stanowiło to odpowiednio 38 i 5\% liczby Polaków przebywających w UE, zob. w: Informacja o rozmiarach i kierunkach czasowej emigracji z Polski w latach 2004-2016, Notatka informacyjna z dn. 16.10.2017 r., GUS.
} 
cena w eksporcie rolno-spożywczym konkurentów była wyższa w eksporcie do Luksemburga o 5\%, a w eksporcie do Włoch zaledwie o 1\%. Wśród tych trzech krajów tylko Włochy miały relatywnie duże znaczenie jako odbiorca polskiej żywności. W eksporcie do pozostałych krajów UE wskaźniki RC były wyższe od jedności, co wskazuje na konkurowanie przez polskich producentów żywności przede wszystkim ceną oferowanych produktów. Najsilniejsze przewagi cenowe wobec konkurentów z innych krajów Polska miała w eksporcie produktów rolno-spożywczych do Wielkiej Brytanii. W latach 2014-2016 średnie ceny w polskim eksporcie rolno-spożywczym do tego kraju były o $62 \%$ niższe od cen pozostałych dostawców do Wielkiej Brytanii. Oznacza to, że polscy producenci żywności mieli na rynku brytyjskim silne przewagi cenowe wobec pozostałych konkurentów sprzedających na tym rynku żywność. Silne przewagi cenowe Polska miała także w eksporcie rolno-spożywczym do Czech (wskaźnik RC w latach 2014-2016 wyniósł 1,49$)$ oraz Rumunii $(\mathrm{RC}=1,42)$. W eksporcie do: Irlandii, Finlandii, Holandii i Szwecji średnie ceny konkurentów na rynkach tych krajów były o 30-40\% wyższe od cen oferowanych przez polskich producentów żywności. W eksporcie do: Niemiec, Danii, Grecji, Francji, na Węgry, Słowację, Litwę i do Bułgarii oraz Estonii różnice między cenami osiąganymi przez polskich eksporterów i eksporterów z krajów-konkurentów oscylowały w granicach 20-30\%.

Mimo spadku wartości wskaźników RC w eksporcie do Niemiec, nadal polscy producenci żywności mieli na tym rynku silne przewagi cenowe wobec pozostałych konkurentów. Oznacza to, że cały czas główną strategią konkurencji na rynku najważniejszego dla Polski odbiorcy żywności było konkurowanie niższą ceną oferowanych produktów. Wśród krajów ze wskaźnikiem RC oscylującym w granicach 1,10-1,20 znalazły się: Austria, Hiszpania, Łotwa i Słowenia. W eksporcie do: Belgii, Portugalii, Chorwacji i na Cypr ceny osiągane przez polskich eksporterów żywności były zaledwie o kilka procent niższe niż ceny oferowane przez pozostałych konkurentów.

\subsubsection{Ceny relatywne w eksporcie do państw UE-15 oraz UE-13 według działów HS}

W latach 2004-2006 Polska miała przewagi jakościowe $(\mathrm{RC}<1)$ na rynkach państw UE-15 wobec pozostałych konkurentów światowych w eksporcie przetworów zbożowych i pieczywa cukierniczego, przetworów z owoców i warzyw, produktów przemysłu młynarskiego oraz przetworów z mięsa i ryb. Wskaźniki RC nieznacznie powyżej jedności odnotowano także w eksporcie tłuszczów i olejów, kakao i przetworów z kakao oraz ryb i owoców morza. 
Wśród ww. grup w okresie członkostwa w UE relacja średnich cen oferowanych przez konkurentów z innych krajów do cen oferowanych przez polskie firmy zmniejszyła się tylko w eksporcie ryb i owoców morza (o $0,16 \mathrm{pkt}$ ) oraz nieznacznie w eksporcie kakao i przetworów z kakao (o $0,02 \mathrm{pkt}$ ). W pozostałych grupach produktów wskaźniki RC się zwiększyły. W latach 2014-2016 w dwóch $\mathrm{z}$ ww. grup, tj. rybach i owocach morza oraz przetworach zbożowych i pieczywie cukierniczym, udało się polskim firmom utrzymać przewagi jakościowe w eksporcie do państw UE-15 (wykres 3.3 i tabela 3.2). W eksporcie kakao i przetworów z kakao polscy eksporterzy osiągali takie same ceny jak konkurenci z pozostałych krajów. Pogorszenie relacji średnich cen oferowanych przez konkurentów do cen polskich firm sprawiło, że również w grupie napojów alkoholowych i bezalkoholowych podstawą konkurowania polskich producentów żywności stała się jakość oferowanych produktów $(\mathrm{RC}=0,73 \mathrm{w}$ latach 2014-2016). Wskaźniki RC zmalały także w kilku innych grupach produktów, jednak w eksporcie żadnej z nich nie udało się polskim producentom uzyskać przewag jakościowych w eksporcie do krajów „Piętnastki”.

Wykres 3.3. Wskaźniki cen relatywnych $\mathrm{RC}$ w polskim eksporcie rolno-spożywczym do państw UE-15 i UE-13 według działów HS wobec konkurentów z innych krajów w latach 2014-2016

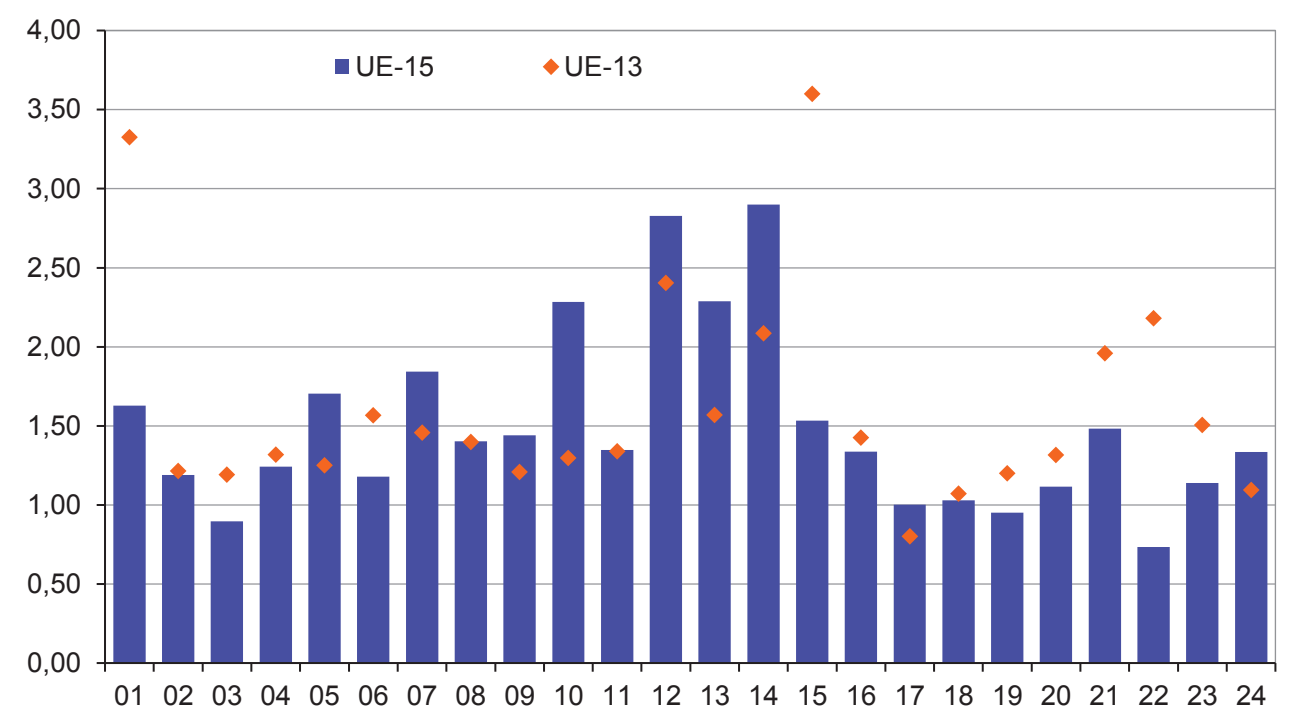

Uwaga: opis działów HS jak w tabeli 3.2.

Źródło: obliczenia własne na podstawie danych WITS-Comtrade. 


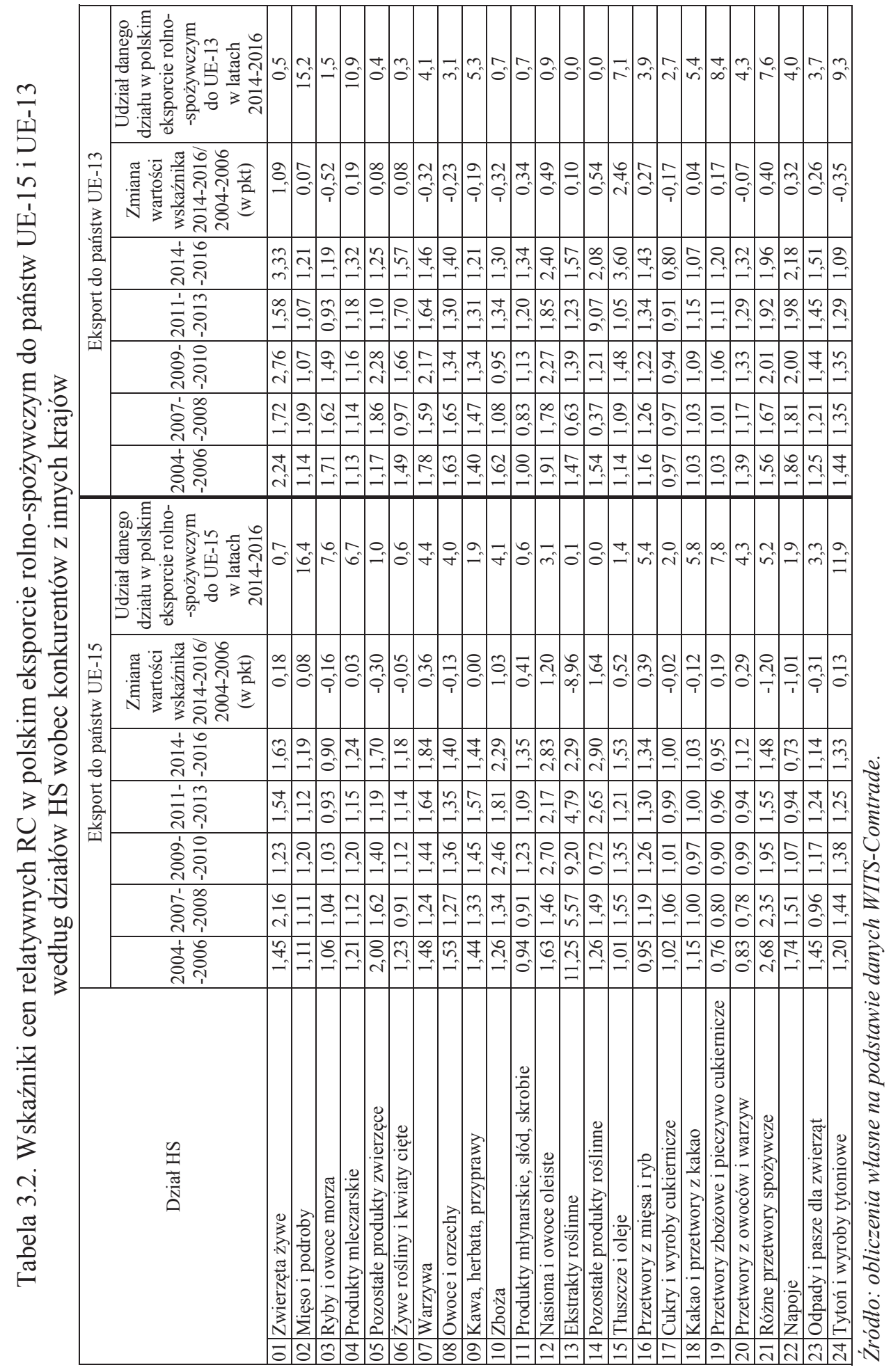


W latach 2014-2016 Polska miała największe przewagi cenowe (wskaźnik $\mathrm{RC}>2,00)$ w eksporcie do państw UE-15 pozostałych produktów roślinnych, nasion i owoców oleistych, zbóż oraz ekstraktów roślinnych. Wskaźniki RC w granicach 1,50-2,00 odnotowano w eksporcie pozostałych produktów pochodzenia zwierzęcego, zwierząt żywych, warzyw oraz tłuszczów i olejów. Z wyjątkiem zbóż, nasion i owoców oleistych oraz warzyw wymienione wyżej grupy produktów miały niewielkie znaczenie w polskim eksporcie do UE-15. W kilku, istotnych dla polskich producentów żywności grupach produktów, średnie ceny w eksporcie konkurentów do krajów „Piętnastki” były o 30-50\% wyższe niż ceny oferowane przez polskie firmy (tabela 3.2 i wykres 3.3). Dotyczyło to: różnych przetworów spożywczych, kawy, herbaty i przypraw, owoców, produktów przemysłu młynarskiego, przetworów z mięsa i ryb oraz tytoniu i wyrobów tytoniowych. Oznacza to, że polscy producenci konkurowali na rynkach państw UE-15 wyraźnie niższą ceną oferowanych produktów. Pogorszenie relacji średnich cen oferowanych przez konkurentów do cen polskich firm (spadek wskaźnika RC) nastąpiło tylko w grupie owoców i różnych przetworów spożywczych. W eksporcie produktów przemysłu mleczarskiego ceny oferowane przez konkurentów były o blisko $25 \%$ wyższe niż cen polskich firm. Wyższe o $10-20 \%$ były ceny oferowane przez konkurentów w eksporcie: mięsa i podrobów, odpadów i pasz dla zwierząt, żywych roślin i kwiatów ciętych oraz przetworów z owoców i warzyw. Wskaźnik RC dla kakao i przetworów z kakao był tylko nieznacznie wyższy od jedności.

W latach 2004-2006 w eksporcie do pozostałych państw członkowskich UE polscy producenci mieli przewagi jakościowe wobec pozostałych konkurentów światowych $(\mathrm{RC}<1)$ tylko w jednej grupie produktów - cukry i wyroby cukiernicze. W kolejnych trzech grupach wskaźniki RC były równe bądź tylko niewiele wyższe od jedności. Dotyczyło to produktów młynarskich, kakao i przetworów z kakao oraz przetworów zbożowych i pieczywa cukierniczego. W eksporcie pozostałych grup produktów ceny światowych konkurentów na rynkach państw UE-13 były wyraźnie wyższe od cen oferowanych przez polskie firmy.

W okresie członkostwa Polski w UE wskaźniki RC w eksporcie rolno-spożywczym do państw UE-13 zmalały w zaledwie ośmiu z dwudziestu czterech działów HS. Największy spadek, bo o ponad 0,50 pkt, odnotowano w grupie ryby i owoce morza. W eksporcie tytoniu i wyrobów tytoniowych, warzyw oraz zbóż wskaźniki RC zmalały o nieco ponad 0,30 pkt, a w eksporcie owoców, kawy, herbaty i przypraw oraz cukrów i wyrobów cukierniczych - o około 0,20 pkt. Mimo tych spadków w żadnej innej - niż cukry i wyroby cukiernicze - grupie produktów nie udało się polskim producentom osiągnąć w latach 2014-2016 
przewag jakościowych w państwach UE-13. W eksporcie kakao i przetworów z kakao oraz tytoniu i wyrobów tytoniowych ceny światowych konkurentów były zaledwie o kilka procent niższe niż ceny oferowane przez polskie firmy. Najwyższe wskaźniki RC (powyżej 3,00) odnotowano w przypadku tłuszczów i olejów oraz zwierząt żywych. W eksporcie napojów, nasion i owoców oleistych oraz pozostałych produktów pochodzenia roślinnego ceny oferowane przez światowych konkurentów na rynkach państw UE-13 były ponad dwukrotnie wyższe niż ceny oferowane przez polskie firmy, zaś w eksporcie różnych przetworów spożywczych, odpadów i pasz dla zwierząt, ekstraktów roślinnych oraz roślin żywych i kwiatów ciętych - ponad półtorakrotnie wyższe. Silne przewagi cenowe wobec światowych konkurentów $(1,30<\mathrm{RC}<1,50)$ Polska miała w państwach UE-13 także w eksporcie: warzyw, owoców, przetworów z owoców i warzyw, zbóż, produktów młynarskich, produktów mleczarskich, przetworów z mięsa i ryb. Te grupy produktów stanowiły w latach $2014-2016$ blisko $30 \%$ polskiego eksportu rolno-spożywczego do państw UE-13. O 20-30\% wyższe ceny produktów oferowane przez światowych konkurentów w porównaniu z cenami polskich firm odnotowano w eksporcie: mięsa i podrobów, kawy, herbaty i przypraw, przetworów zbożowych i pieczywa cukierniczego. W eksporcie ryb i owoców morza średnie ceny oferowane przez polskich producentów były o kilkanaście procent niższe od cen konkurentów na rynkach państw UE-13, a w eksporcie kakao i przetworów z kakao oraz tytoniu i wyrobów tytoniowych - zaledwie o kilka procent niższe.

Ciekawych wniosków dostarcza analiza cen relatywnych w eksporcie poszczególnych grup produktów (według działów HS) na rynki poszczególnych krajów UE. W eksporcie mięsa i podrobów (najważniejsza pozycja w eksporcie według działów HS) Polska miała przewagi jakościowe tylko na rynkach dwóch krajów, tj. Belgii i Irlandii (tabela 3.3). W pozostałych krajach konkurowała niższą ceną sprzedawanych produktów. W eksporcie do: Wielkiej Brytanii, na Węgry, do Szwecji, Estonii i Słowenii przewagi cenowe były słabe - ceny mięsa i podrobów oferowane przez konkurentów były zaledwie o kilka procent wyższe od cen polskich firm. W eksporcie tytoniu i wyrobów tytoniowych polscy producenci mieli przewagi jakościowe na rynkach ośmiu krajów UE, m.in.: we Włoszech, na Litwie, Łotwie, w Belgii i Bułgarii. Szczególnie wysokie wskaźniki RC cechowały natomiast polski eksport tytoniu i wyrobów tytoniowych do Wielkiej Brytanii $(\mathrm{RC}=4,41)$, a także do Niemiec, Szwecji i Francji (RC powyżej 2,00). Oznacza to, że ceny wyrobów tytoniowych oferowane przez światowych konkurentów na rynku brytyjskim były blisko czteroipółkrotnie wyższe od cen polskich firm. 


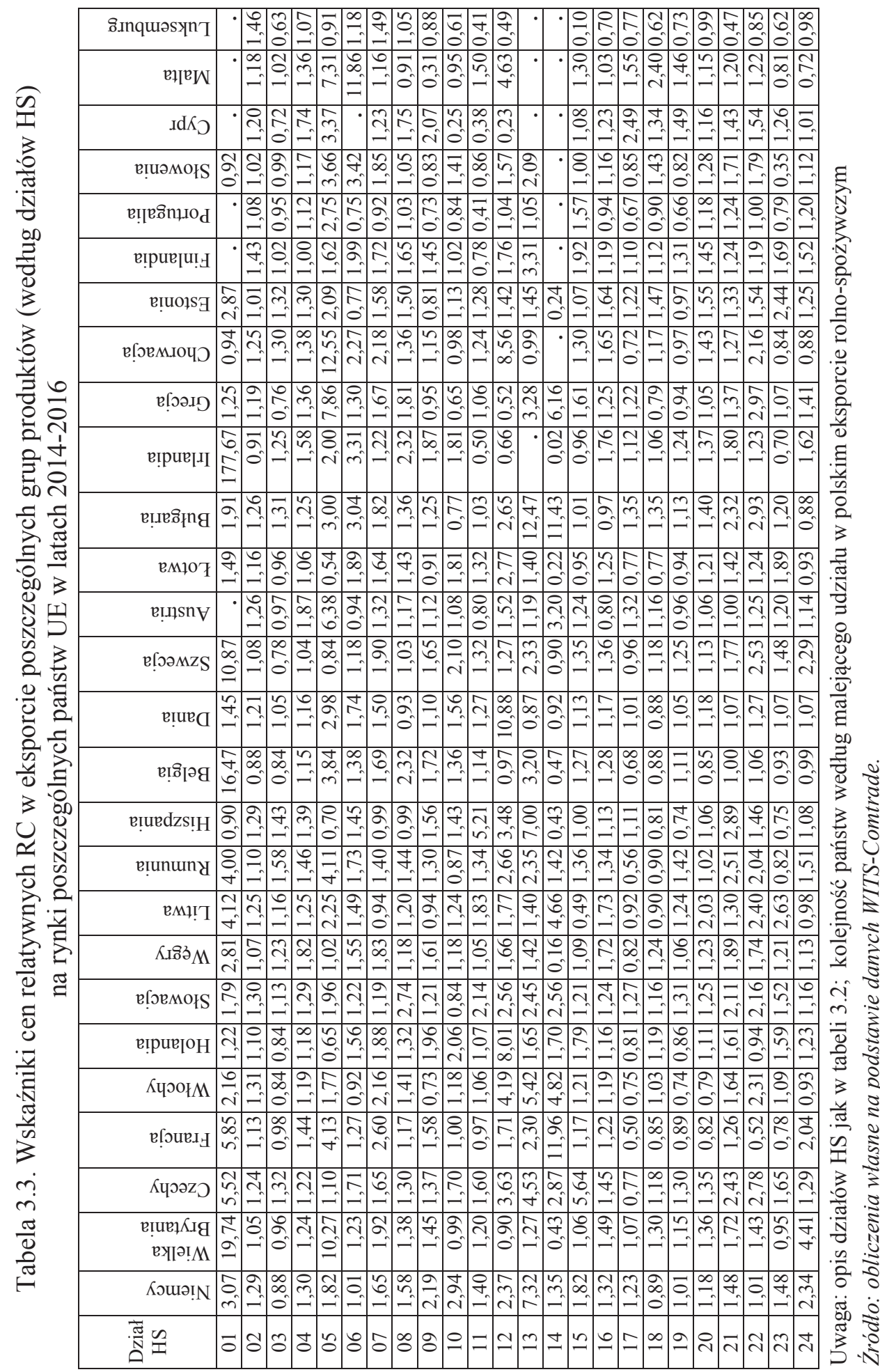


W eksporcie przetworów zbożowych i pieczywa cukierniczego polscy producenci konkurowali jakością na rynkach aż dwunastu krajów, m.in.: we Francji, Włoszech, Holandii, Hiszpanii i Austrii. Ceny tych produktów oferowanych przez światowych konkurentów były niższe od cen oferowanych przez polskie firmy. Wskaźniki RC nieco poniżej jedności odnotowano także w dostawach do Niemiec, na Węgry i do Danii.

Zwraca uwagę, że w latach 2014-2016 w polskim eksporcie produktów mleczarskich, jaj i miodu do wszystkich krajów UE wskaźniki RC kształtowały się powyżej jedności. Oznacza to, że polscy producenci konkurowali niższą ceną sprzedawanych na rynku unijnym produktów. Niewiele było też unijnych krajów, na rynkach których polskie firmy miały przewagi jakościowe wobec światowych konkurentów w eksporcie warzyw (tylko na Litwie, w Hiszpanii i Portugalii), owoców (w Hiszpanii, Danii i na Malcie), przetworów z owoców i warzyw (we Francji, Włoszech, Belgii i Luksemburgu), pozostałych przetworów spożywczych (w Luksemburgu) oraz napojów (we Francji, Holandii i Luksemburgu). Szczególnie silne przewagi jakościowe wobec konkurentów polskie firmy miały w eksporcie napojów do Francji $(\mathrm{RC}=0,52)$ oraz pozostałych przetworów spożywczych do Luksemburga $(\mathrm{RC}=0,47)$.

W eksporcie niektórych grup produktów (według działów HS) polskie firmy miały przewagi jakościowe na rynkach nawet kilkunastu krajów. Dotyczyło to ryb i owoców morza (14 krajów, m.in.: Niemcy, Wielka Brytania, Francja, Włochy, Holandia), cukrów i wyrobów cukierniczych (14 krajów, m.in.: Czechy, Francja, Włochy, Holandia, Węgry), kakao i przetworów z kakao (11 krajów, m.in.: Niemcy, Francja, Litwa, Rumunia, Hiszpania) oraz odpadów i pasz dla zwierząt (11 krajów, m.in.: Wielka Brytania, Francja, Rumunia, Hiszpania, Belgia). Szczególnie niskie wskaźniki RC (poniżej 0,60) odnotowano w polskim eksporcie cukrów i wyrobów cukierniczych do Francji i Rumunii, napojów do Francji oraz odpadów i pasz dla zwierząt do Słowenii.

\subsubsection{Struktura polskiego eksportu do państw UE-15 oraz UE-13 według posiadanych przewag nad konkurentami}

Wskaźniki cen relatywnych można również wykorzystać do podziału polskiego eksportu produktów rolno-spożywczych do krajów Unii Europejskiej pod względem posiadanych przewag nad konkurentami z innych krajów. Z analizy struktury tego eksportu wynika, że w latach 2004-2016 dla przeważającej części polskiego eksportu zarówno do państw UE-15, jak i UE-13 ceny oferowane przez światowych konkurentów były wyższe niż oferowane przez polskie firmy. Oznacza to, że polscy producenci konkurowali na rynku unijnym głównie niższymi cenami 
sprzedawanych produktów. Nieco wyższy był przy tym ten odsetek eksportu w przypadku sprzedaży w nowych państwach członkowskich UE niż w krajach „Piętnastki”. W niektórych latach nawet ponad 35\% polskiego eksportu rolno-spożywczego do państw UE-15 było efektem konkurowania przez polskie firmy jakością. W latach 2014-2016 udział polskiego eksportu do UE-15, którego podstawą były przewagi jakościowe, ukształtował się średnio na poziomie około $30 \%$, podczas gdy udział polskiego eksportu do UE-13 - na poziomie blisko $24 \%$ (wykres 3.4). Było to zatem odpowiednio o blisko 5 pkt proc. i 2 pkt proc. mniej niż przeciętnie w latach 2004-2006. Tym samym w latach 2014-2016 około 70\% polskiego eksportu rolno-spożywczego do krajów „Piętnastki” i 76\% eksportu do nowych państw członkowskich Unii Europejskiej wynikało z konkurowania niższymi cenami oferowanymi przez polskich producentów w porównaniu z ich światowymi konkurentami.

Wykres 3.4. Struktura polskiego eksportu do państw UE-15 oraz UE-13 według posiadanych przewag nad konkurentami w latach 2004-2016 (w proc.)

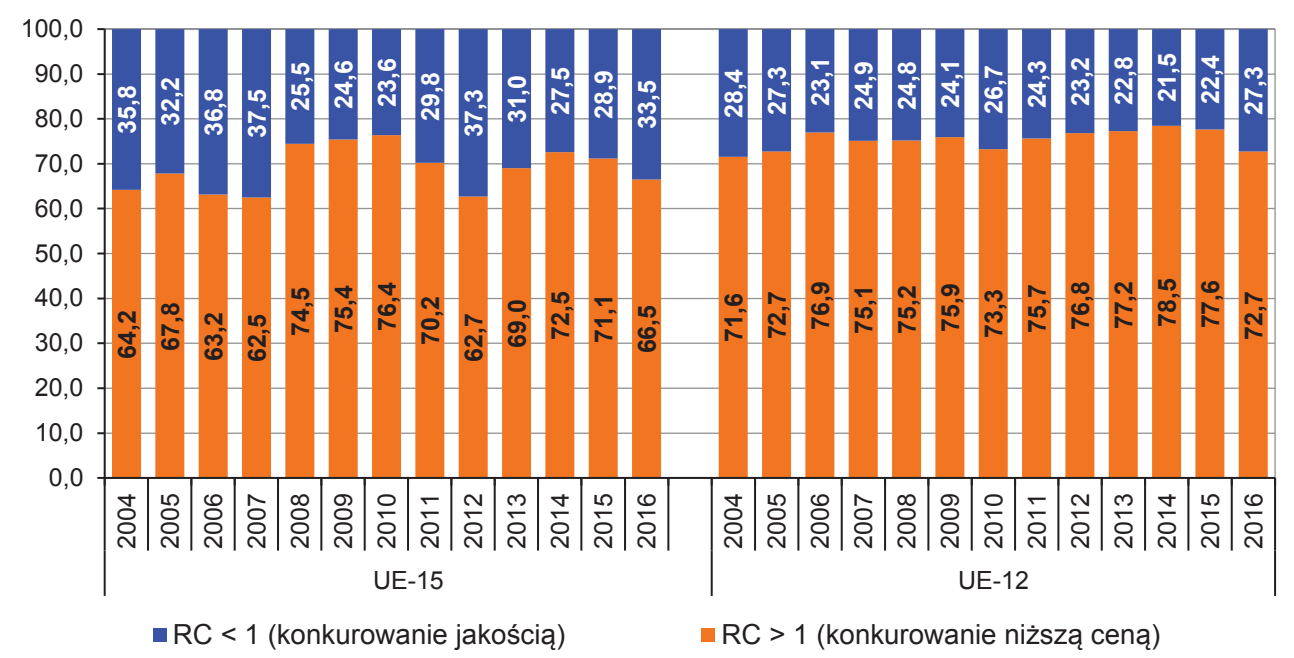

Źródto: obliczenia wtasne na podstawie danych WITS-Comtrade.

W okresie członkostwa Polski w UE udział eksportu, którego podstawą były przewagi jakościowe, zwiększył się tylko w czterech krajach „Piętnastki” i sześciu nowych państwach członkowskich. Największą poprawę odnotowano w przypadku krajów, które miały niewielkie znaczenie jako odbiorcy polskiej żywności, a mianowicie Luksemburga, Malty i Cypru (tabela 3.4 i wykres 3.5). Wyraźnie wzrosło także znaczenie przewag jakościowych w eksporcie na Litwę i Łotwę. Natomiast w eksporcie do Francji i Włoch udział dostaw, dla których wyższe były ceny oferowane przez polskie firmy niż przez konkurentów, zwięk- 
szył się odpowiednio o 5 i 6 pkt proc. Największy spadek znaczenia przewag jakościowych dotyczył polskiego eksportu do: Irlandii, Austrii, Wielkiej Brytanii, Holandii, Belgii, Hiszpanii, Słowenii, na Węgry i Słowację. W latach 2014-2016 ponad $80 \%$ polskiego eksportu rolno-spożywczego do: Finlandii, Wielkiej Brytanii, Czech, Słowenii i na Węgry wynikało z konkurowania niższą ceną oferowanych produktów. Konkurowanie jakością miało największe znaczenie w eksporcie do Luksemburga i na Maltę, a w mniejszym stopniu na Cypr, do Portugalii i Hiszpanii oraz na Łotwę.

Tabela 3.4. Struktura polskiego eksportu do poszczególnych państw UE według posiadanych przewag nad konkurentami w latach 2004-2006 oraz 2014-2016 (w proc.)

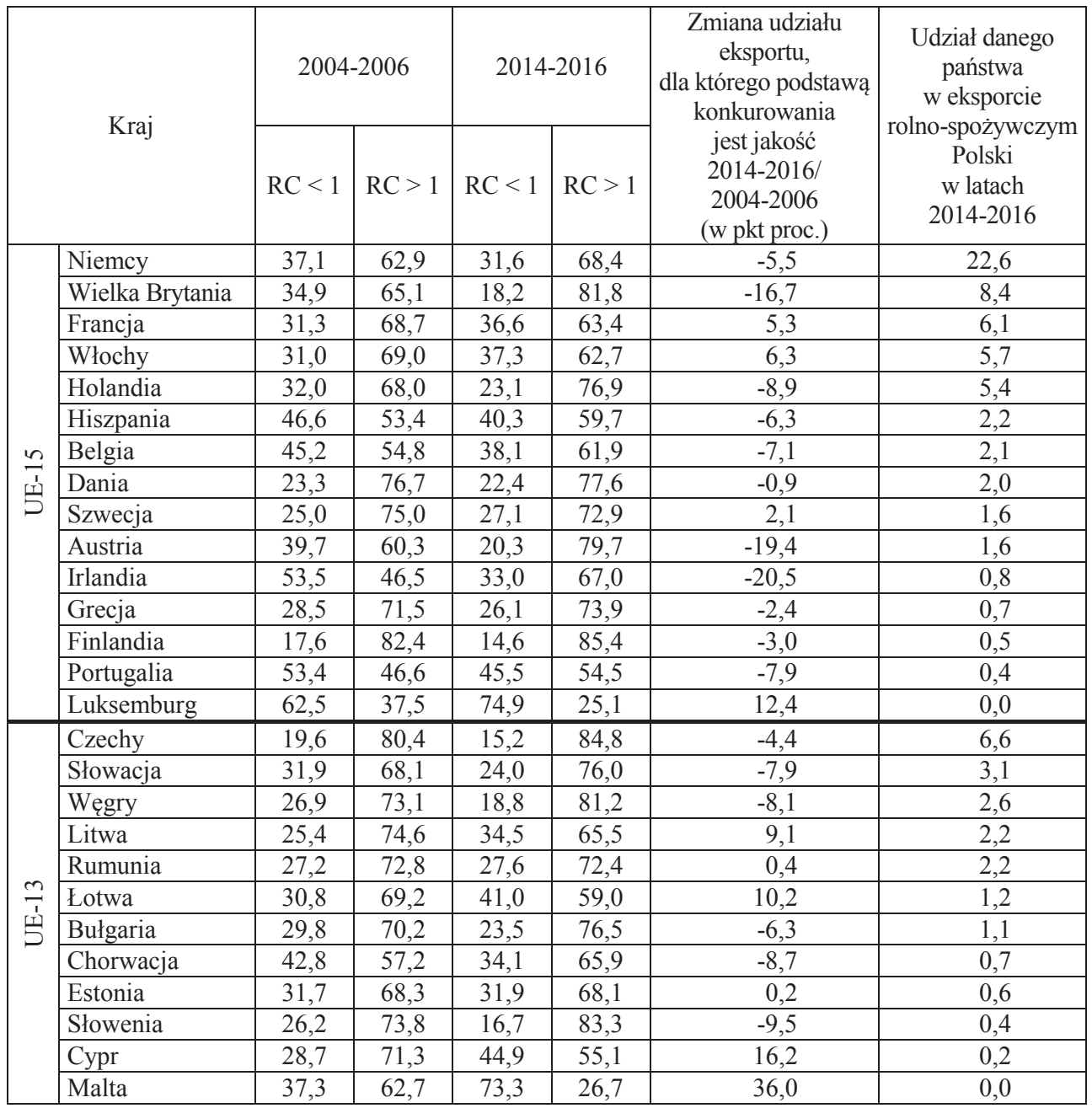

Źródto: obliczenia własne na podstawie danych WITS-Comtrade. 
Wykres 3.5. Struktura polskiego eksportu rolno-spożywczego do poszczególnych państw UE według posiadanych przewag nad konkurentami w latach 2014-2016 (w proc.)

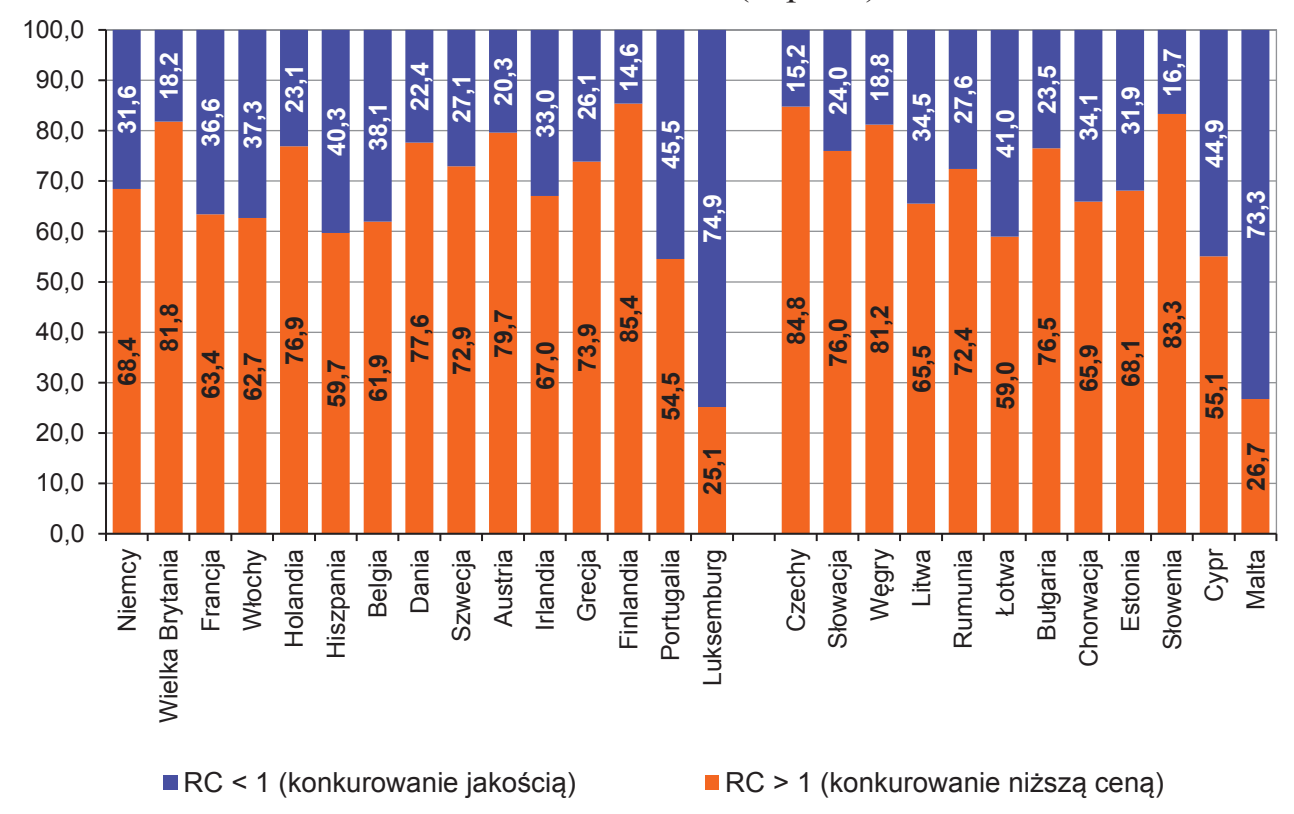

Źródto: obliczenia wtasne na podstawie danych WITS-Comtrade.

Wśród grup produktów wyodrębnionych według działów HS największy wzrost znaczenia strategii konkurowania jakością w okresie członkostwa Polski w Unii Europejskiej nastąpił w eksporcie do państw UE-15 takich produktów, jak: ryby i owoce morza, ekstrakty roślinne, pozostałe produkty pochodzenia roślinnego, napoje oraz kakao i przetwory z kakao, a w eksporcie do państw UE-13 następujących produktów: cukrów i wyrobów cukierniczych, tytoniu i wyrobów tytoniowych oraz owoców (tabela 3.5). Niekorzystne zmiany, tj. wzrost znaczenia konkurowania niższymi cenami, zaszły natomiast w eksporcie do UE-15 przetworów z owoców i warzyw, mięsa i podrobów oraz przetworów z mięsa i ryb, a w eksporcie do UE-13 - przetworów z mięsa i ryb, tłuszczów i olejów, odpadów i pasz dla zwierząt, pozostałych produktów pochodzenia zwierzęcego oraz produktów młynarskich.

W latach 2014-2016 blisko 87\% polskiego eksportu ryb i owoców morza, blisko połowa eksportu napojów oraz przetworów zbożowych i pieczywa cukierniczego, a także ponad $40 \%$ eksportu kakao i przetworów z kakao do krajów „Piętnastki” było efektem konkurowania przez polskie firmy jakością oferowanych produktów. Na przeciwległym biegunie znalazły się zaś warzywa, owoce oraz pozostałe przetwory spożywcze, których zaledwie kilka procent polskiego 
eksportu do krajów UE-15 wynikało ze strategii konkurowania jakością. W przypadku państw UE-13 w latach 2014-2016 blisko 60\% eksportu cukrów i wyrobów cukierniczych, niemal połowa eksportu zwierząt żywych oraz blisko 40\% eksportu zbóż było efektem konkurowania jakością. Najniższy udział eksportu, dla którego ceny oferowane przez konkurentów były wyższe niż przez polskie firmy, dotyczył napojów oraz różnych przetworów spożywczych.

Tabela 3.5. Struktura polskiego eksportu do państw UE-15 oraz UE-13 według posiadanych przewag nad konkurentami w poszczególnych działach HS w latach 2004-2006 oraz 2014-2016 (w proc.)

\begin{tabular}{|c|c|c|c|c|c|c|c|c|}
\hline \multirow[b]{2}{*}{$\begin{array}{c}\text { Dział } \\
\text { HS }\end{array}$} & \multicolumn{4}{|c|}{ Eksport do UE-15 } & \multicolumn{4}{|c|}{ Eksport do UE-13 } \\
\hline & $\begin{array}{l}2004- \\
-2006\end{array}$ & $\begin{array}{l}2014- \\
-2016\end{array}$ & $\begin{array}{c}\text { Zmiana } \\
\text { udziału } \\
\text { (w pkt proc.) }\end{array}$ & $\begin{array}{c}\text { Udział danego } \\
\text { działu w polskim } \\
\text { eksporcie rolno- } \\
\text {-spożywczym } \\
\text { do UE-15 } \\
\text { w latach } \\
\text { 2014-2016 }\end{array}$ & $\begin{array}{l}2004- \\
-2006\end{array}$ & $\begin{array}{l}2014- \\
-2016\end{array}$ & $\begin{array}{c}\text { Zmiana } \\
\text { udziału } \\
\text { (w pkt proc.) }\end{array}$ & $\begin{array}{l}\text { Udział danego } \\
\text { działu w polskim } \\
\text { eksporcie rolno- } \\
\text {-spożywczym } \\
\text { do UE-13 } \\
\text { w latach } \\
\text { 2014-2016 }\end{array}$ \\
\hline 01 & 55,1 & 48,8 & $-6,3$ & 0,7 & 35,8 & 46,9 & 11,1 & 0,5 \\
\hline 02 & 56,1 & 29,5 & $-26,6$ & 16,4 & 19,9 & 29,2 & 9,3 & 15,2 \\
\hline 03 & 42,0 & 86,9 & 44,9 & 7,6 & 49,4 & 34,5 & $-14,9$ & 1,5 \\
\hline 04 & 16,7 & 18,6 & 1,9 & 6,7 & 29,9 & 16,8 & $-13,1$ & 10,9 \\
\hline 05 & 9,3 & 23,9 & 14,6 & 1,0 & 34,5 & 11,8 & $-22,7$ & 0,4 \\
\hline 06 & 23,9 & 38,0 & 14,1 & 0,6 & 7,4 & 20,5 & 13,0 & 0,3 \\
\hline 07 & 6,8 & 4,6 & $-2,2$ & 4,4 & 5,9 & 17,4 & 11,4 & 4,1 \\
\hline 08 & 15,7 & 6,0 & $-9,7$ & 4,0 & 12,8 & 28,9 & 16,1 & 3,1 \\
\hline 09 & 17,5 & 22,5 & 5,0 & 1,9 & 14,1 & 20,9 & 6,8 & 5,3 \\
\hline 10 & 14,8 & 10,9 & $-4,0$ & 4,1 & 28,1 & 39,1 & 11,0 & 0,7 \\
\hline 11 & 22,0 & 25,5 & 3,5 & 0,6 & 34,1 & 14,3 & $-19,7$ & 0,7 \\
\hline 12 & 20,0 & 21,1 & 1,1 & 3,1 & 26,6 & 17,6 & $-9,0$ & 0,9 \\
\hline 13 & 5,1 & 42,5 & 37,5 & 0,1 & 32,3 & 36,2 & 3,9 & 0,0 \\
\hline 14 & 11,5 & 47,0 & 35,5 & 0,0 & 30,5 & 39,7 & 9,2 & 0,0 \\
\hline 15 & 31,2 & 23,7 & $-7,5$ & 1,4 & 40,4 & 17,7 & $-22,7$ & 7,1 \\
\hline 16 & 46,5 & 17,0 & $-29,5$ & 5,4 & 43,6 & 12,1 & $-31,5$ & 3,9 \\
\hline 17 & 31,4 & 24,0 & $-7,4$ & 2,0 & 21,6 & 58,3 & 36,7 & 2,7 \\
\hline 18 & 26,7 & 44,6 & 17,8 & 5,8 & 45,9 & 38,9 & $-6,9$ & 5,4 \\
\hline 19 & 49,5 & 49,3 & $-0,2$ & 7,8 & 44,1 & 27,7 & $-16,4$ & 8,4 \\
\hline 20 & 84,6 & 31,4 & $-53,2$ & 4,3 & 37,7 & 30,7 & $-6,9$ & 4,3 \\
\hline 21 & 11,8 & 7,6 & $-4,2$ & 5,2 & 15,9 & 9,7 & $-6,2$ & 7,6 \\
\hline 22 & 24,7 & 48,4 & 23,7 & 1,9 & 19,0 & 7,1 & $-11,9$ & 4,0 \\
\hline 23 & 28,2 & 27,1 & $-1,1$ & 3,3 & 43,1 & 20,8 & $-22,3$ & 3,7 \\
\hline 24 & 27,2 & 21,1 & $-6,1$ & 11,9 & 9,2 & 26,4 & 17,2 & 9,3 \\
\hline
\end{tabular}

Uwaga: opis działów HS jak w tabeli 3.2.

Źródło: obliczenia własne na podstawie danych WITS-Comtrade. 


\subsubsection{Porównanie otrzymanych wyników z weześniejszymi badaniami}

Otrzymane wyniki tylko częściowo potwierdzają wnioski z wcześniejszych badań jakościowo-cenowych strategii konkurencji polskich producentów żywności prowadzonych w IERiGŻ-PIB. W dotychczasowych badaniach dokonywano oceny konkurencyjności cenowo-jakościowej według metody zaproponowanej przez K. Aigingera we wzajemnym handlu Polski z krajami Unii Europejskiej (również z krajami spoza UE). Jak już wspomniano, metoda ta opiera się na wykorzystaniu dwóch miar konkurencyjności, tj. relacji średnich cen w eksporcie do średnich cen w imporcie oraz salda wymiany handlu zagranicznego w ujęciu ilościowym. Wyższa cena danego produktu w polskim eksporcie do UE niż cena tego produktu w polskim imporcie z UE wskazywała na konkurowanie jakością przez polskich producentów na rynku unijnym. W badaniu, którego wyniki przedstawiono w niniejszym rozdziale, zastosowano wskaźnik cen relatywnych. Pozwolił on na porównanie cen produktów oferowanych przez polskich producentów na rynku Unii Europejskiej z cenami produktów oferowanych na tym rynku przez konkurentów z innych krajów. W sytuacji, gdy ceny oferowane przez konkurentów są wyższe niż ceny oferowane przez polskich producentów, mamy do czynienia ze strategią konkurowania niższą ceną.

Z badań przeprowadzonych według obu metod wynika, że duża część polskiego eksportu kierowanego w latach 2004-2016 zarówno do państw UE-15, jak i UE-13 była efektem konkurowania niższymi cenami oferowanych produktów ${ }^{168}$. Według metody cen relatywnych udział eksportu, którego podstawą było konkurowanie niższą ceną, był wyraźnie wyższy niż według metody K. Aigingera. Według obu metod konkurowanie ceną miało większe znaczenie w eksporcie do państw UE-13 niż do krajów „Piętnastki”.

Wyniki obu przeprowadzonych badań wskazują, że polscy producenci po akcesji do UE konkurowali jakością w eksporcie cukrów i wyrobów cukierniczych do państw UE-13, a także w eksporcie ryb i owoców morza oraz przetworów zbożowych i pieczywa cukierniczego do państw UE-15. W eksporcie produktów mleczarskich na rynki krajów „Piętnastki” polscy producenci konkurowali zaś niższymi cenami.

Każdy z mierników pozycji konkurencyjnej, do których należą również metody oparte na wartościach jednostkowych w handlu zagranicznym, posiada zarówno zalety, jak i wady. Każdy z nich odnosi się do innego aspektu konkurencyjności. Jak wspomniano, metoda K. Aigingera odwołuje się do relacji cen we wzajemnym handlu dwóch krajów. Wskaźniki cen relatywnych umożliwiają natomiast porównanie cen produktów oferowanych przez producentów danego

${ }^{168}$ I. Szczepaniak, Jakościowo-cenowe strategie konkurencji.., op.cit. 
kraju na wybranym rynku z cenami oferowanymi na tym rynku przez konkurentów z innych krajów. Stąd też wykorzystywanie obu mierników jednocześnie pozwala na bardziej miarodajną ocenę konkurencyjności cenowo-kosztowej producentów na danym rynku.

\subsection{Podsumowanie}

Z przeprowadzonego badania wynika, że w latach 2004-2016 Polska miała w eksporcie rolno-spożywczym zarówno do państw UE-15, jak i UE-13 cenowe przewagi konkurencyjne nad pozostałymi konkurentami. Oznacza to, że ceny oferowane przez polskich producentów żywności na rynkach tych państw były niższe niż ceny oferowane przez kraje-konkurentów. W badanym okresie wyższe wskaźniki cen relatywnych (a więc niższe ceny w porównaniu z konkurentami) notowano w eksporcie do nowych państw członkowskich UE niż do krajów „Piętnastki”. W eksporcie do obu grup krajów brak było wyraźnych tendencji kształtowania się wskaźników RC, a w eksporcie do państw UE-13 wskaźniki te dodatkowo charakteryzowały się dużą zmiennością.

W latach 2014-2016 wskaźnik RC w polskim eksporcie rolno-spożywczym do państw UE-15 wyniósł średnio 1,23, a do państw UE-13 - 1,30. Oznacza to, że średnie ceny w polskim eksporcie na rynki tych krajów były odpowiednio o 23 i 30\% niższe niż ceny konkurentów z innych krajów. W porównaniu z latami 2004-2006 wskaźniki RC zmalały odpowiednio o zaledwie 0,02 pkt i 0,01 pkt. Udział polskiego eksportu do UE-15, którego podstawą były przewagi cenowe, ukształtował się w latach 2014-2016 na poziomie około $70 \%$, podczas gdy udział polskiego eksportu do UE-13 - na poziomie blisko 76\%. Było to zatem odpowiednio o blisko 5 i 2 pkt proc. więcej niż przeciętnie w latach 2004-2006. Tym samym w latach 2014-2016 tylko około 30\% polskiego eksportu do krajów „Piętnastki” i 24\% eksportu do nowych państw członkowskich UE wynikało z konkurowania jakością oferowanych produktów.

W okresie członkostwa Polski w UE przewagi cenowe polskich producentów żywności wobec konkurentów z innych krajów osłabiły się (świadczy o tym spadek wskaźnika RC) w eksporcie do trzynastu krajów UE (najbardziej w eksporcie: na Maltę, Litwę, Cypr, do Hiszpanii i Włoch). W latach 2014-2016 Polska miała przewagi jakościowe wobec konkurentów $(\mathrm{RC}<1) \mathrm{w}$ eksporcie rolno-spożywczym do zaledwie trzech krajów, tj. na Maltę, do Luksemburga i Włoch. W eksporcie do pozostałych krajów UE wskaźniki RC były wyższe od jedności, co wskazuje na konkurowanie przez polskich producentów żywności ceną oferowanych produktów. Najsilniejsze przewagi cenowe wobec konkurentów z innych krajów Polska miała w eksporcie produktów rolno-spożywczych do: Wielkiej Brytanii, Czech, Rumunii, Irlandii, Finlandii, Holandii i Szwecji. 
Spośród działów HS w latach 2014-2016 Polska miała przewagi jakościowe $(\mathrm{RC}<1)$ w eksporcie do państw UE-15 następujących grup produktów: ryb i owoców morza, napojów oraz przetworów zbożowych i pieczywa cukierniczego. Najwyższe wskaźniki RC odnotowano natomiast w eksporcie nasion i owoców oleistych, zbóż, warzyw oraz pozostałych przetworów spożywczych. Oznacza to, że ceny oferowane przez polskich producentów były wyraźnie niższe niż ceny konkurentów z innych krajów. W eksporcie do państw UE-13 wskaźniki RC niższe od jedności w latach 2014-2016 odnotowano tylko w grupie cukrów i wyrobów cukierniczych. W pozostałych grupach produktów polscy producenci konkurowali niższą ceną sprzedawanych produktów. Największe przewagi cenowe polscy producenci mieli wobec konkurentów z innych krajów w państwach UE-13 w eksporcie: tłuszczów i olejów, nasion i owoców oleistych, napojów, pozostałych przetworów spożywczych oraz odpadów i pasz dla zwierząt.

Stosowanie przez polskich producentów żywności w okresie członkostwa Polski w Unii Europejskiej strategii konkurowania niższą ceną w eksporcie na rynek unijny z całą pewnością pozwoliło im umocnić pozycję konkurencyjną na tym rynku. W dłuższej perspektywie przewagi cenowe mogą jednak okazać się niewystarczające, a wręcz stanowić zagrożenie. Otóż strategia konkurowania niższą ceną jest budowana w oparciu o przewagi kosztowe, które m.in. zależą od poziomu i zmian cen czynników produkcji, w tym jednostkowych kosztów pracy $^{169}$. Tymczasem w warunkach wyrównywania się kosztów produkcji w krajach Unii Europejskiej zmniejszać się będzie znaczenie cenowych czynników konkurencyjności. Niezbędne stanie się zatem wykorzystywanie w coraz większym stopniu przez polskich producentów żywności pozacenowych instrumentów konkurowania, w tym konkurowania jakością oferowanych produktów.

\footnotetext{
${ }^{169}$ Ponadto przewagi kosztowe zależą również od zmian nominalnego kursu walutowego. Prowadzone badania wskazują jednak, że zmiany te mają coraz mniejszy wpływ na kształtowanie się polskiego eksportu rolno-spożywczego. Szerzej: Ł. Ambroziak, I. Szczepaniak, Ryzyko kursowe a handel zagraniczny produktami rolno-spożywczymi Polski, [w:] J. Góral i M. Wigier (red.), Ryzyko w gospodarce żywnościowej - teoria i praktyka, seria „Monografie Programu Wieloletniego 2015-2019”, nr 48, IERiGŻ-PIB, Warszawa 2017, s. 89-105.
} 


\section{Umowy o wolnym handlu UE z Ukrainą, Gruzją i Mołdawią a konkurencyjność polskich producentów żywności}

\subsection{Wprowadzenie}

Jednym z głównych celów polityki zagranicznej Unii Europejskiej jest nawiązywanie nowych oraz zacieśnianie już istniejących relacji między UE i jej wschodnimi sąsiadami poprzez pogłębianie współpracy politycznej i integracji gospodarczej. Wymiar polityki zewnętrznej UE w ramach Europejskiej Polityki Sąsiedztwa określa Program Partnerstwa Wschodniego (PW) uruchomiony w 2009 roku. Obejmuje on sześć państw, tj.: Ukrainę, Białoruś, Mołdawię, Gruzję, Azerbejdżan i Armenię. Jego celem jest zbliżenie tych krajów do UE, a w efekcie podpisanie umów stowarzyszeniowych i powołanie stref wolnego handlu pomiędzy UE a państwami partnerskimi ${ }^{170}$. Dotychczas jednak tylko z Ukrainą, Mołdawią i Gruzją zostały zawarte nowe wiążące ramy prawne współpracy ${ }^{171}$. Białoruś, Armenia i Azerbejdżan ze względu na skomplikowaną sytuację wewnętrzną nie nawiązały bliższych relacji w ramach Partnerstwa Wschodniego.

Unia Europejska i Ukraina prowadziły negocjacje w sprawie podpisania umowy o stowarzyszeniu od marca 2007 roku. Ze względu na sytuację polityczną na Ukrainie podpisanie politycznej części umowy stowarzyszeniowej nastąpiło w marcu 2014 roku, natomiast druga, gospodarcza część umowy - Porozumienie o pogłębionej i całościowej strefie wolnego handlu między UE i Ukrainą (Deep and Comprehensive Free Trade Agreement - DCFTA) - zostało podpisane 27 czerwca 2014 roku. Natomiast już 22 kwietnia 2014 roku, w celu wsparcia Ukrainy w trudnej sytuacji politycznej i gospodarczej, UE udzieliła jej dodatkowych autonomicznych preferencji jednostronnych, liberalizując dostęp do swojego rynku zgodnie z koncesjami przewidzianymi w załączniku I-A części handlowej układu stowarzyszeniowego UE-Ukraina ${ }^{172}$. Umowa DCFTA między UE a Ukrainą weszła w życie 1 stycznia 2016 roku. To najważniejsza i największa część podpisanej w 2014 roku umowy stowarzyszeniowej. Dotyczy ona utworzenia strefy wolnego handlu, ale także przewiduje przyjęcie przez Ukrainę

\footnotetext{
${ }^{170}$ https://ec.europa.eu/neighbourhood-enlargement/neighbourhood/eastern-partnership_en (dostęp: 27.09.2017).

${ }^{171}$ T. Michalewski, Umowy o stowarzyszeniu z UE $w$ ramach partnerstwa wschodniego wybrane zagadnienia, [w:] M. Sadowski (red.), Z badań nad prawem, administracja i myśla polityczna, Uniwersytet Wrocławski, 2015.

${ }^{172}$ Rozporządzenie Parlamentu Europejskiego i Rady (UE) nr 374/2014 z 16 kwietnia 2014 r. w sprawie obniżenia lub zniesienia ceł na towary pochodzące z Ukrainy, Dz. Urz. UE L 118 z 22.04.2014.
} 
około $60 \%$ unijnego prawa, w tym regulacji w zakresie przepisów: technicznych, sanitarnych, fitosanitarnych, celnych i dotyczących ochrony własności intelektualnej. Ma ponadto stworzyć równe warunki konkurencji. Układ o stowarzyszeniu UE z Ukrainą wszedł w życie 1 września 2017 roku $^{173}$.

27 czerwca 2014 roku UE podpisała również układy o stowarzyszeniu z Gruzją i Mołdawią. Weszły one w życie w całości 1 lipca 2016 roku, jednak najważniejsza i najbardziej obszerna część tych umów, czyli porozumienia o pogłębionej i całościowej strefie wolnego handlu (DCFTA), w większości były już tymczasowo stosowane od września 2014 roku. Umowy stowarzyszeniowe mają stopniowo integrować te kraje z rynkiem unijnym. Proces ten ma być możliwy m.in. dzięki zniesieniu większości ceł i barier handlowych oraz dostosowaniu do standardów unijnych.

Celem niniejszego rozdziału jest próba oceny wpływu zawarcia przez Unię Europejską umów DCFTA z Ukrainą, Mołdawią i Gruzją na handel rolno-spożywczy Polski, w tym na konkurencyjność polskich producentów żywności na tych rynkach. Ocena ta została poprzedzona charakterystyką handlu rolno-spożywczego Polski z tymi trzema krajami, analizą barier we wzajemnej wymianie handlowej oraz omówieniem najważniejszych postanowień umów DCFTA w kwestii liberalizacji obrotów handlowych produktami rolno-spożywczymi.

Źródłem danych o strumieniach handlu zagranicznego produktami rolno-spożywczymi była baza WITS-Comtrade. Do analizy stawek celnych wykorzystano WTO World Tariff Profiles. W opracowaniu pod pojęciem Unii Europejskiej rozumie się 28 państw członkowskich. Do produktów rolno-spożywczych zaliczono produkty z działów 01-24 HS, z wyjątkiem punktu dotyczącego stawek celnych, w którym przyjęto definicję stosowaną przez $\mathrm{WTO}^{174}$.

\subsection{Handel rolno-spożywczy Polski z Ukrainą, Mołdawią i Gruzją}

Spośród trzech analizowanych państw PW najważniejszym partnerem Polski w handlu rolno-spożywczym jest Ukraina. Mołdawia i Gruzja mają zdecydowanie mniejsze znaczenie. Obroty handlowe z Mołdawią są ponad trzynastokrotnie, a z Gruzją ponad dwudziestokrotnie mniejsze niż z Ukrainą. O ile w handlu z Ukrainą i Mołdawią Polska od 2011 roku posiadała deficyt (w przypadku Ukrainy z wyjątkiem 2013 roku), o tyle w handlu z Gruzją począwszy od 2011 roku odnotowuje rosnące dodatnie saldo obrotów handlowych. W 2016 roku

\footnotetext{
${ }^{173} \mathrm{https} / / /$ ec.europa.eu/poland/news/170901_ue_ukraine_pl (dostęp: 27.09.2017).

${ }^{174}$ Według definicji WTO z produktów rolno-spożywczych wyłączono ryby i przetwory z ryb, natomiast dodatkowo zaliczono niektóre produkty rolne o charakterze nieżywnościowym spoza działów 01-24 HS (np. bawełnę i skóry).
} 
na te trzy kraje przypadało 1,6\% polskiego eksportu rolno-spożywczego ogółem i $8,3 \%$ eksportu rolno-spożywczego poza UE. W imporcie udziały te wynosiły odpowiednio 3,0 oraz $9,3 \%$. Polska jest najważniejszym partnerem w handlu żywnością dla Białorusi oraz drugim co do ważności dla Ukrainy (po Hiszpanii). Dla pozostałych państw PW ma mniejsze, choć również istotne, znaczenie jako partner w handlu żywnością.

Do 2014 roku Ukraina była drugim po Rosji największym rynkiem zbytu polskich produktów rolno-spożywczych spośród krajów spoza UE. W 2016 roku Ukraina zajmowała zaś dwudzieste miejsce wśród największych odbiorców polskich produktów żywnościowych oraz piąte wśród krajów spoza UE (plasując się za Rosją, USA, Arabią Saudyjską i Białorusią). Mimo że w 2016 roku w porównaniu z 2013 rokiem wartość polskiego eksportu na Ukrainę zmniejszyła się o 40\% (do $361 \mathrm{mln}$ USD), udział tego kraju w polskim eksporcie poza UE zwiększył się dwuipółkrotnie - z 2,9 do 7,2\%. Było to wynikiem znaczącego spadku wartości wywozu do Rosji w związku z wprowadzonym przez Rosję w połowie 2014 roku embargiem na przywóz większości produktów spożyw$\mathrm{czych}^{175}$. Z kolei spadek wielkości polskiego eksportu rolno-spożywczego na Ukrainę był spowodowany osłabieniem hrywny. Do 2010 roku Polska była eksporterem netto żywności na rynek ukraiński. Od 2011 roku Polska posiada ujemne saldo obrotów handlowych (wyjątek stanowił 2013 rok), które w 2016 roku osiągnęło rekordową wartość $125 \mathrm{mln}$ USD (wykres 4.1).

Wykres 4.1. Polski handel produktami rolno-spożywczymi z Ukrainą (w mln USD)

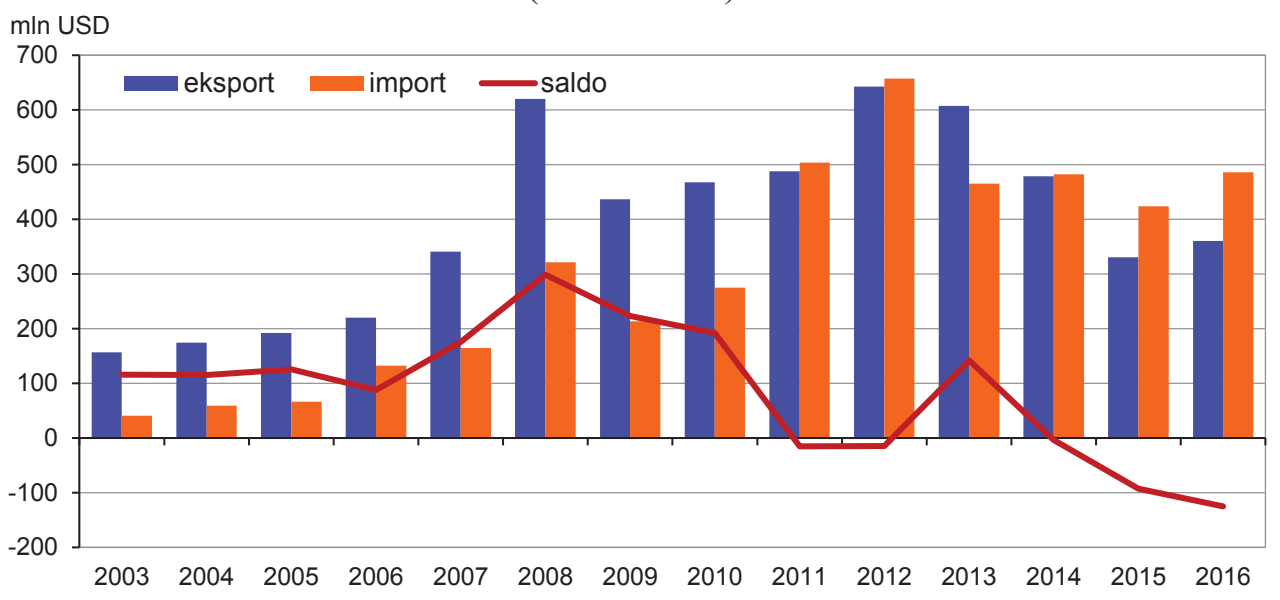

Źródto: obliczenia wtasne na podstawie WITS-Comtrade.

\footnotetext{
${ }^{175}$ Ł. Ambroziak, I. Szczepaniak, Skutki rosyjskiego embarga na import produktów rolno-spożywczych, „Przemysł Spożywczy” 2014, nr 9, s. 2-8.
} 


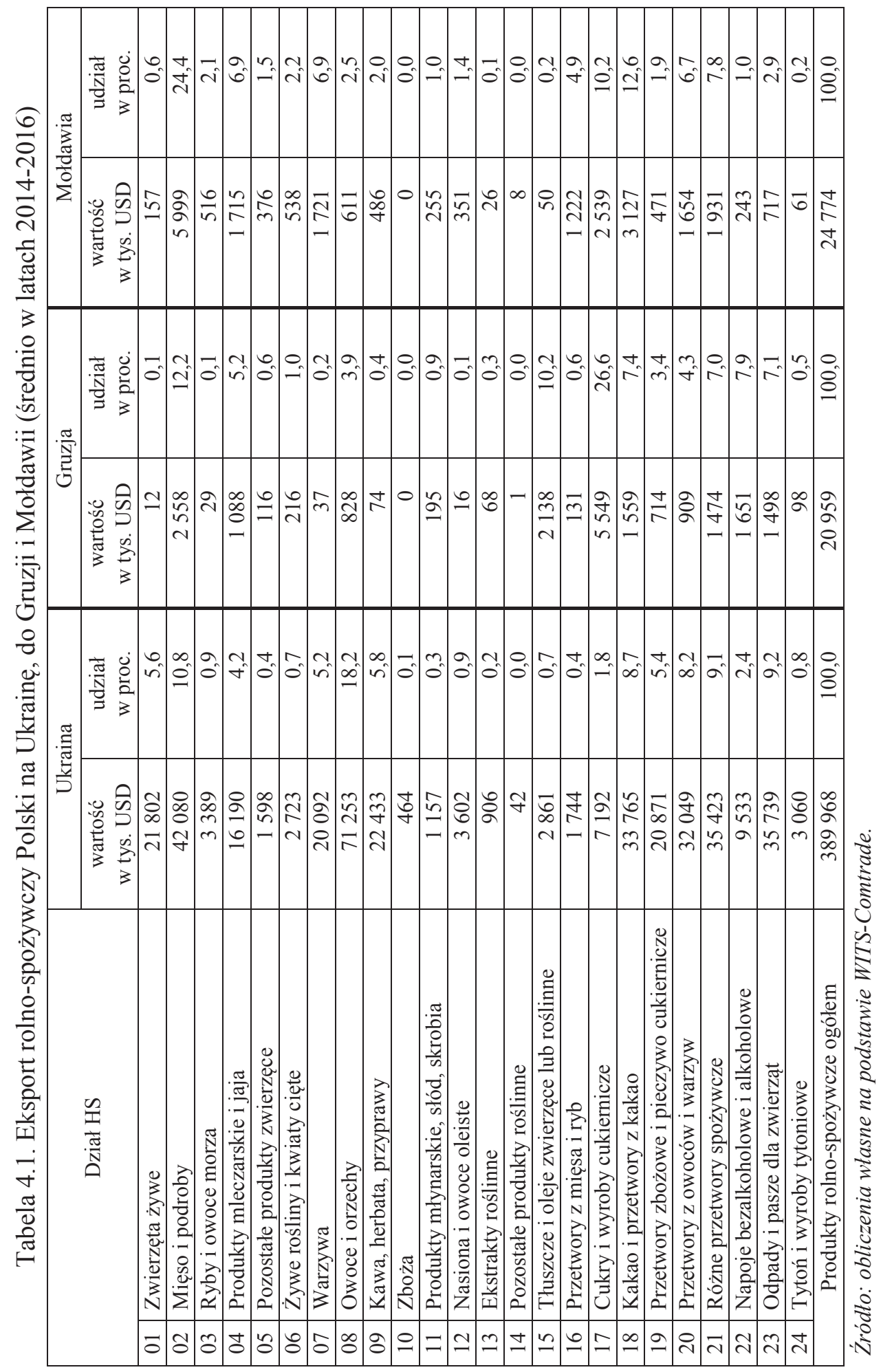


Polska eksportowała na Ukrainę głównie owoce (mandarynki, brzoskwinie i jabłka), mięso i podroby (mięso drobiowe i thuszcze pochodzenia zwierzęcego), odpady i pasze dla zwierząt oraz różne przetwory (w tym syropy cukrowe) por. tabela 4.1. Sprowadzała natomiast odpady i pasze dla zwierząt (makuchy ze słonecznika), nasiona i owoce oleiste (nasiona rzepaku), thuszcze i oleje (sojowy i rzepakowy) oraz inne produkty pochodzenia roślinnego (tabela 4.2). W 2015 roku Polska była drugim po Hiszpanii największym dostawcą żywności na Ukrainę (w 2013 roku zajmowała czwartą pozycję, za Rosją i Turcją).

Polskie obroty handlowe z Gruzją systematycznie się zwiększają. Szczególnie dynamiczny wzrost eksportu polskiej żywności na rynek gruziński miał miejsce po 2010 roku. W latach 2010-2016 wartość polskiego wywozu do Gruzji zwiększyła się ponad czterokrotnie, do 28,7 mln USD (wykres 4.2). Od 2011 roku Polska odnotowuje dodatnie i rosnące saldo obrotów handlowych, które w 2016 roku osiągnęło rekordową wartość 21,3 mln USD. Polska eksportuje do Gruzji głównie cukier i wyroby cukiernicze oraz tłuszcze zwierzęce (tabela 4.1), sprowadza natomiast wino, orzechy oraz przyprawy (tabela 4.2). W 2016 roku Polska była szóstym co do wielkości - za Rosją, Ukrainą, Turcją, Brazylią i Niemcami - dostawcą żywności do Gruzji (podczas gdy w 2010 roku uplasowała się na osiemnastej pozycji). Warto także podkreślić, że w 2016 roku Polska była drugim po Ukrainie największym dostawcą cukru na rynek gruziński.

Wykres 4.2. Polski handel produktami rolno-spożywczymi z Gruzją (w mln USD)

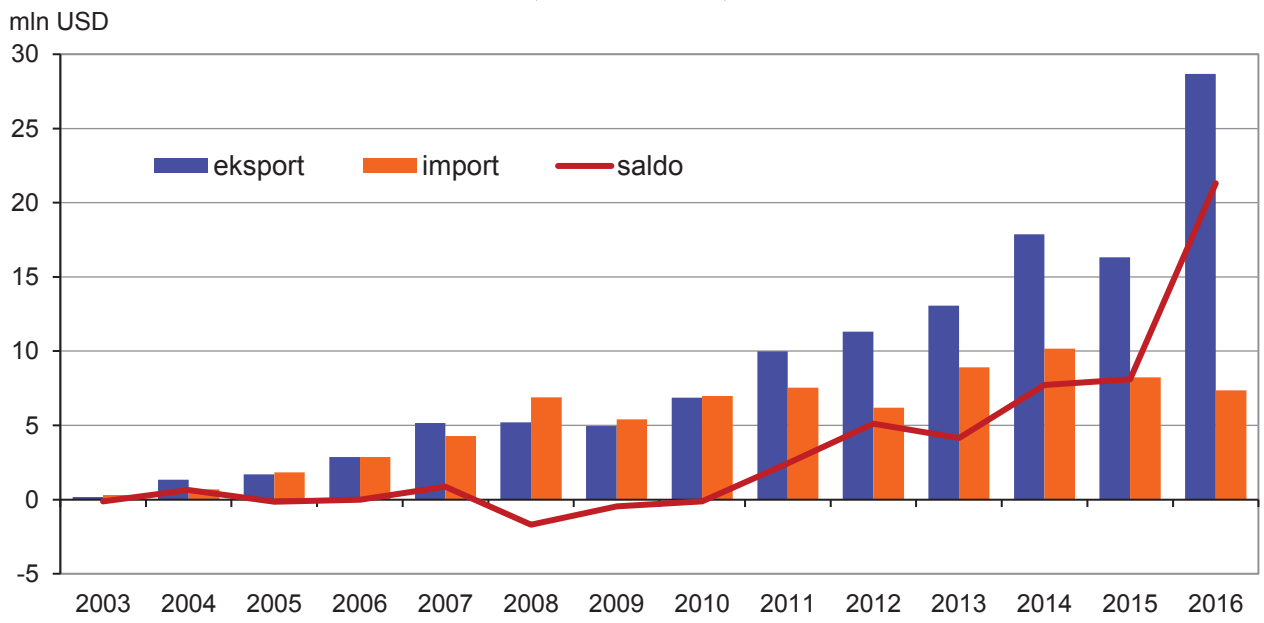

Źródto: obliczenia wtasne na podstawie WITS-Comtrade. 


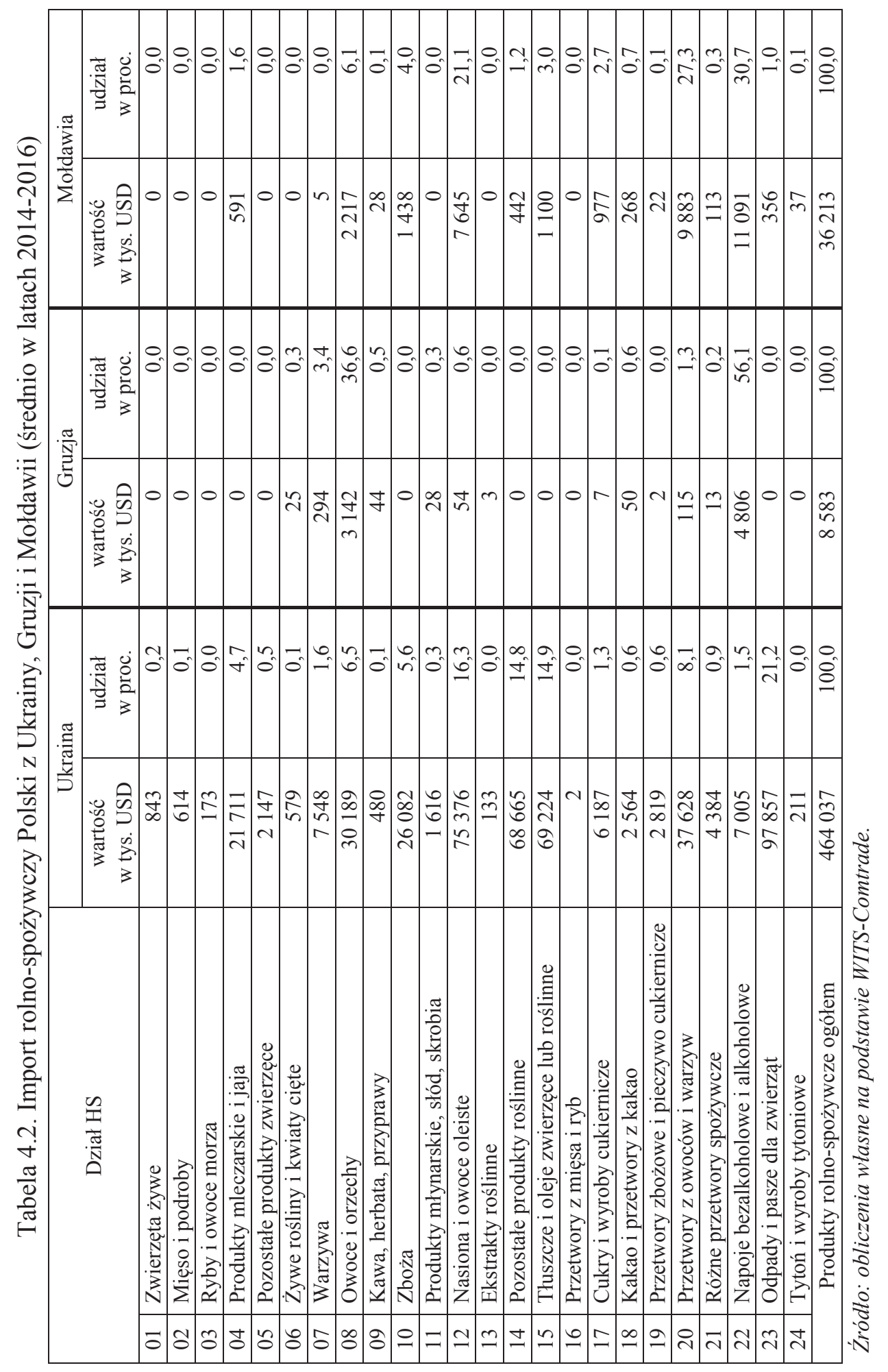


W analizowanym okresie wartość polskiego eksportu rolno-spożywczego do Mołdawii wykazywała niewielkie wahania i oscylowała wokół 25 mln USD, podczas gdy import dynamicznie wzrastał, uzyskując w 2011 roku rekordową wartość $45 \mathrm{mln}$ USD (wykres 4.3). W kolejnych latach wartość przywozu stopniowo malała, jednak wciąż utrzymywała się na relatywnie wysokim poziomie, w 2016 roku wynoszącym 27 mln USD. Szybszy rozwój importu niż eksportu spowodował, że Polska, począwszy od 2011 roku, posiadała deficyt w handlu z Mołdawią. Polska eksportowała na rynek mołdawski przede wszystkim mięso wieprzowe i drobiowe, cukier, pastę kakaową oraz ziemniaki (tabela 4.1). Sprowadzała natomiast soki owocowe, wino, nasiona słonecznika, rzepaku i lnu oraz alkohol etylowy (tabela 4.2). W 2016 roku Polska była piątym co do wielkości dostawcą żywności do Mołdawii, za: Ukrainą, Rosją, Rumunią i Niemcami.

Wykres 4.3. Polski handel produktami rolno-spożywczymi z Mołdawią (w mln USD)

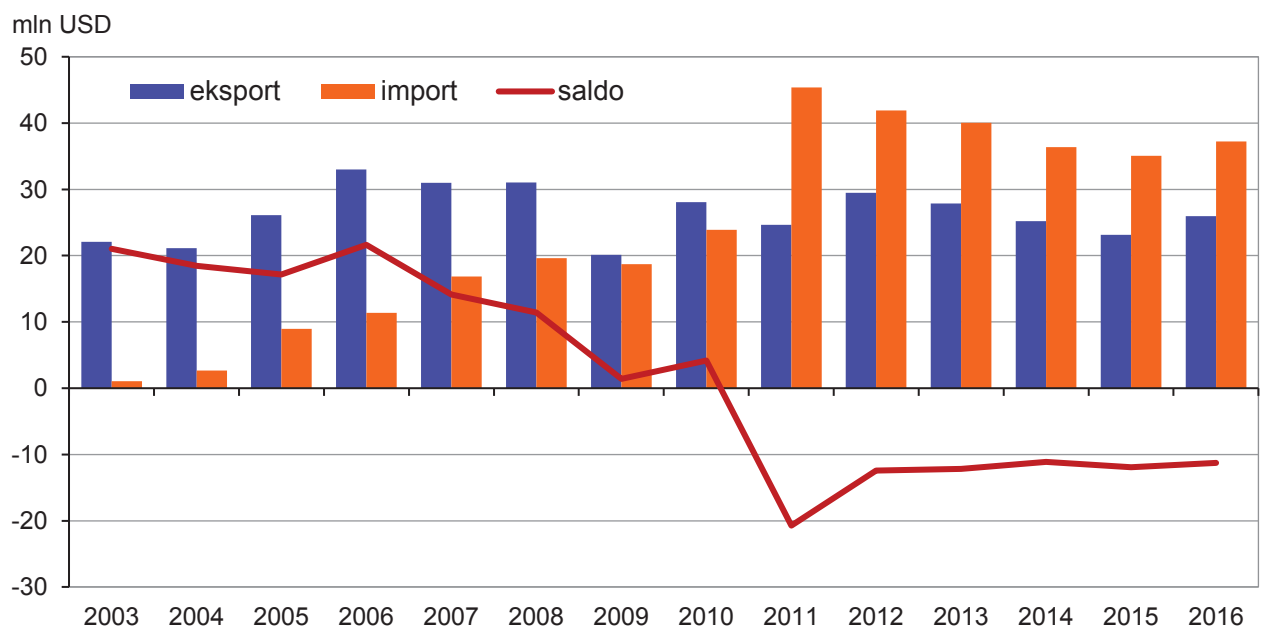

Źródto: obliczenia własne na podstawie WITS-Comtrade.

W latach 2014-2016 w handlu rolno-spożywczym z Ukrainą Polska uzyskiwała dodatnie saldo w piętnastu spośród dwudziestu czterech działów HS (tabela 4.3), w tym największe w handlu mięsem i podrobami, owocami (m.in. dzięki reeksportowi mandarynek i brzoskwiń) oraz wyrobami czekoladowymi. Z kolei największy deficyt wystąpił $\mathrm{w}$ handlu nasionami i owocami oleistymi, olejami roślinnymi i odpadami (makuchami ze słonecznika). Z Mołdawią największą nadwyżkę Polska odnotowała w handlu mięsem i podrobami oraz przetworami z kakao, a deficyt - w handlu napojami alkoholowymi (winami) oraz przetworami z owoców i warzyw (sokami). W przypadku Gruzji Polska uzyskiwała najwyższe 
dodatnie saldo obrotów w handlu cukrem, mięsem i podrobami oraz thuszczami zwierzęcymi. Deficyt występował z kolei w handlu napojami alkoholowymi (winami) oraz owocami i orzechami. Warto podkreślić, że Ukraina jest znaczącym eksporterem netto żywności na świecie. Dodatnie saldo obrotów w handlu tą grupą produktów posiada także Mołdawia, natomiast Gruzja jest trwałym importerem netto żywności.

Tabela 4.3. Saldo obrotów handlowych produktami rolno-spożywczymi Polski z Ukrainą, Gruzją i Mołdawią (średnio w latach 2014-2016, w tys. USD)

\begin{tabular}{|c|c|c|c|c|}
\hline \multicolumn{2}{|r|}{ Dział HS } & \multirow{2}{*}{$\begin{array}{r}\text { Ukraina } \\
20959\end{array}$} & \multirow{2}{*}{$\begin{array}{r}\text { Gruzja } \\
12\end{array}$} & \multirow{2}{*}{$\begin{array}{r}\text { Mołdawia } \\
157\end{array}$} \\
\hline 01 & Zwierzęta żywe & & & \\
\hline 02 & Mięso i podroby & 41467 & 2558 & 5999 \\
\hline 03 & Ryby i owoce morza & 3216 & 29 & 516 \\
\hline 04 & Produkty mleczarskie i jaja & -5522 & 1088 & 1124 \\
\hline 05 & Pozostałe produkty zwierzęce & -549 & 116 & 376 \\
\hline 06 & Żywe rośliny i kwiaty cięte & 2143 & 191 & 538 \\
\hline 07 & Warzywa & 12544 & -257 & 1716 \\
\hline 08 & Owoce i orzechy & 41064 & -2315 & -1606 \\
\hline 09 & Kawa, herbata, przyprawy & 21954 & 30 & 458 \\
\hline 10 & Zboża & -25618 & 0 & -1438 \\
\hline 11 & Produkty młynarskie, słód, skrobia & -459 & 167 & 255 \\
\hline 12 & Nasiona i owoce oleiste & -71774 & -38 & -7293 \\
\hline 13 & Ekstrakty roślinne & 773 & 66 & 26 \\
\hline 14 & Pozostałe produkty roślinne & -68623 & 1 & -434 \\
\hline 15 & Tłuszcze i oleje zwierzęce lub roślinne & -66363 & 2138 & -1050 \\
\hline 16 & Przetwory z mięsa i ryb & 1742 & 131 & 1222 \\
\hline 17 & Cukry i wyroby cukiernicze & 1006 & 5542 & 1562 \\
\hline 18 & Kakao i przetwory z kakao & 31201 & 1509 & 2860 \\
\hline 19 & Przetwory zbożowe i pieczywo cukiernicze & 18052 & 712 & 448 \\
\hline 20 & Przetwory z owoców i warzyw & -5579 & 794 & -8229 \\
\hline 21 & Różne przetwory spożywcze & 31039 & 1461 & 1818 \\
\hline 22 & Napoje bezalkoholowe i alkoholowe & 2528 & -3155 & -10847 \\
\hline 23 & Odpady i pasze dla zwierząt & -62118 & 1498 & 360 \\
\hline 24 & Tytoń i wyroby tytoniowe & 2849 & 98 & 24 \\
\hline & Produkty rolno-spożywcze ogółem & -74068 & 12376 & -11438 \\
\hline
\end{tabular}

Źródło: obliczenia własne na podstawie WITS-Comtrade.

\subsection{Bariery w handlu Unii Europejskiej, Ukrainy, Gruzji i Mołdawii}

\subsubsection{Bariery taryfowe}

Stawki celne na produkty rolno-spożywcze (według definicji WTO) w analizowanych krajach kształtowały się na zbliżonym, niezbyt wysokim poziomie. Najwyższą średnią arytmetyczną stawkę celną KNU na te produkty posiadała 
w 2015 roku Mołdawia - 11,5\%. Nieco niższa była stawka w Unii Europejskiej $10,7 \%$ oraz na Ukrainie $-9,2 \%$, natomiast najniższa w Gruzji - 6,3\% (tabela 4.4). Relatywnie niski poziom stawek celnych wskazuje na wysoki stopień otwarcia poszczególnych rynków już przed podpisaniem umowy DCFTA. Niemniej jednak istnieją grupy produktów wrażliwych, na które stawki celne są wysokie, a dodatkowo duże znaczenie mają bariery pozataryfowe.

Tabela 4.4. Stawki celne KNU na produkty rolno-spożywcze w Unii Europejskiej, na Ukrainie, w Gruzji i Mołdawii w 2015 roku

\begin{tabular}{|c|c|c|c|c|c|c|c|c|c|c|c|c|}
\hline \multirow{2}{*}{ Produkty } & \multicolumn{4}{|c|}{$\begin{array}{c}\text { Średnia } \\
\text { arytmetyczna } \\
\text { stawka celna KNU } \\
\text { (w proc.) }\end{array}$} & \multicolumn{4}{|c|}{$\begin{array}{l}\text { Maksymalna } \\
\text { stawka } \\
\text { (w proc.) }\end{array}$} & \multicolumn{4}{|c|}{$\begin{array}{l}\text { Udział importu } \\
\text { bezcłowego } \\
\text { (w proc.) }\end{array}$} \\
\hline & 岇 & 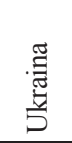 & $\stackrel{\frac{\pi}{N}}{\stackrel{5}{J}}$ & $\frac{\sqrt[\pi]{5}}{\sum_{0}^{\frac{0}{0}}}$ & 岇 & 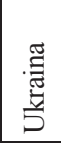 & $\stackrel{\stackrel{\sigma}{N}}{\stackrel{J}{J}}$ & $\frac{\sqrt[\pi]{5}}{\frac{\pi}{0}}$ & 岇 & $\begin{array}{l}\text { 节 } \\
\frac{\vec{g}}{5}\end{array}$ & 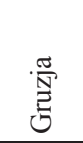 & $\frac{\sqrt[\pi]{5}}{\sum_{0}^{\frac{0}{0}}}$ \\
\hline Produkty zwierzęce & 15,0 & 10,6 & 8,4 & 15,1 & 111 & 20 & 12 & 25 & 17,4 & 18,9 & 5,2 & 14,1 \\
\hline Produkty mleczarskie & 33,5 & 10,0 & 5,4 & 14,2 & 96 & 10 & 12 & 32 & 0 & 0 & 64,3 & 0 \\
\hline Owoce, warzywa i rośliny & 10,3 & 9,9 & 9,0 & 12,8 & 146 & 20 & 12 & 20 & 15,0 & 55,5 & 10,3 & 8,7 \\
\hline Kawa i herbata & 6,0 & 5,7 & 4,6 & 10,6 & 19 & 20 & 12 & 15 & 72,1 & 39,7 & 19,9 & 0 \\
\hline Zboża i produkty zbożowe & 12,4 & 12,4 & 6,7 & 11,0 & 42 & 20 & 25 & 15 & 43,4 & 47,6 & 61,4 & 22,5 \\
\hline $\begin{array}{l}\text { Nasiona oleiste, thuszcze } \\
\text { i oleje }\end{array}$ & 6,0 & 8,3 & 0,1 & 10,1 & 138 & 30 & 12 & 20 & 72,8 & 76,7 & 66,1 & 2,8 \\
\hline $\begin{array}{l}\text { Cukier i wyroby } \\
\text { cukiernicze }\end{array}$ & 20,2 & 19,4 & 10,6 & 15,0 & 63 & 50 & 12 & 15 & 22,7 & 0 & 53,3 & 0 \\
\hline Napoje i tytoń & 19,4 & 7,8 & 18,1 & 12,9 & 135 & 52 & 328 & 55 & 21,1 & 24,6 & 0,5 & 0 \\
\hline Pozostałe produkty rolne & 3,2 & 5,4 & 0,3 & 7,6 & 58 & 20 & 12 & 20 & 70,1 & 21,1 & 94,6 & 27,3 \\
\hline Bawełna & 0,0 & 1,4 & 0,0 & 0,0 & 0 & 5 & 0 & 0 & 100,0 & 45,7 & 100,0 & 100,0 \\
\hline $\begin{array}{l}\text { Produkty rolno-spożywcze } \\
\text { (według WTO) }\end{array}$ & 10,7 & 9,2 & 6,3 & 11,5 & & & • & ${ }^{\circ}$ & & $\cdot$ & & \\
\hline Ryby i produkty rybne & 12,0 & 2,7 & 0,0 & 4,0 & 23 & 20 & 0 & 15 & 25,6 & 74,1 & 100,0 & 74,4 \\
\hline
\end{tabular}

Źródto: opracowanie wtasne na podstawie WTO World Tariff Profiles 2016, s. 81, 85, 120 i 173.

Z analizy wartościowej struktury importu w 2015 roku wynika, że w Unii Europejskiej, podobnie jak na Ukrainie i w Gruzji około 40\% importu odbywało się na zasadach bezcłowych (odpowiednio 46,7; 41,5 i 36,0\%). W Mołdawii wskaźnik ten był czterokrotnie niższy i wyniósł 10,2\%. W Unii Europejskiej 10\% przywozu produktów rolno-spożywczych odbywało się po stawce celnej wyższej niż 25\%, w Mołdawii - 5\%, na Ukrainie - 0,8\%, a w Gruzji - 0\% (wykres 4.4).

W Unii Europejskiej relatywnie niskie cła obowiązują w imporcie produktów pochodzących z innych stref klimatycznych, m.in.: kawy, herbaty, nasion oleistych, tłuszczów i olejów. Wyższym stopniem protekcjonizmu były za to 
objęte podstawowe gałęzie rolnictwa i przemysłu spożywczego. W 2015 roku najwyższe stawki obowiązywały w imporcie produktów mleczarskich $(33,5 \%)$ oraz cukru i wyrobów cukierniczych $(20,2 \%)$. Wysoki poziom protekcji celnej cechował również napoje i tytoń $(19,4 \%)$, produkty zwierzęce $(15,0 \%)$ oraz zboża i produkty zbożowe $(12,4 \%)$.

Wykres 4.4. Wartościowa struktura importu rolno-spożywczego Unii Europejskiej, Ukrainy, Gruzji i Mołdawii w 2015 roku według wysokości stawek celnych (t)

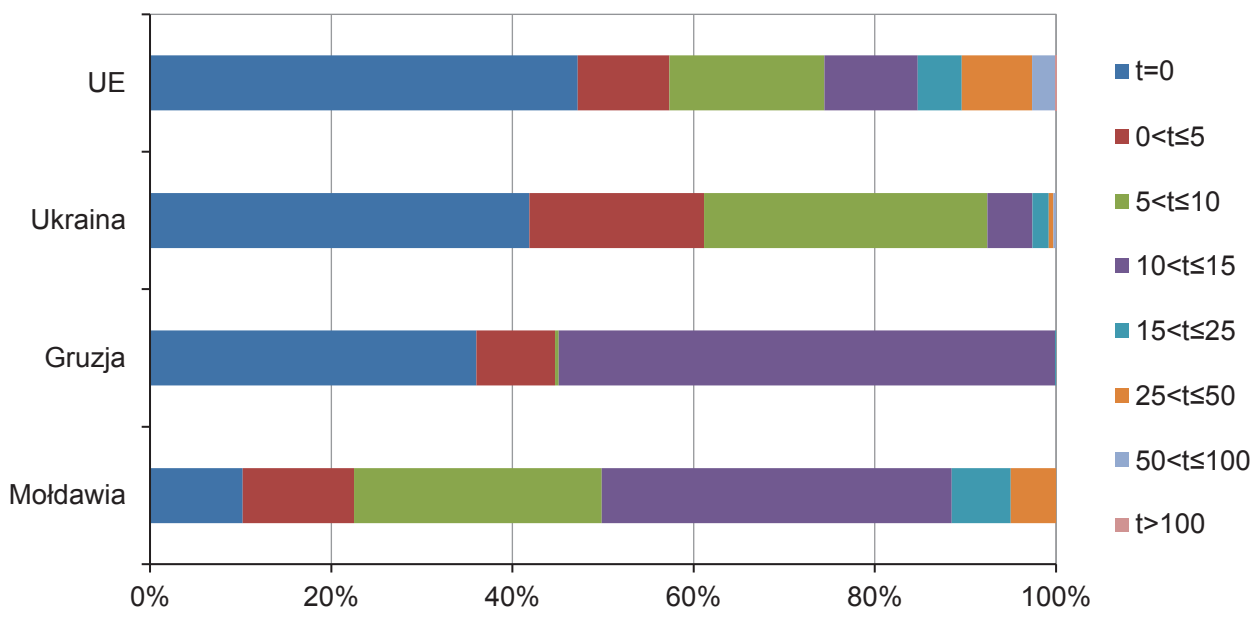

Źródto: opracowanie własne na podstawie WTO World Tariff Profiles 2016, s. 81, 85, 120 i 173.

Na Ukrainie najwyższe cła importowe KNU obwiązywały na: cukier i wyroby cukiernicze $(19,4 \%)$, zboża i produkty zbożowe $(12,4 \%)$, produkty zwierzęce $(10,6 \%)$ oraz produkty mleczarskie $(10,0 \%)$. W pozostałych grupach cła były niższe niż $10 \%$. Najniższe cła dotyczyły bawełny $(1,4 \%)$ oraz ryb i produktów rybnych $(2,7 \%)$. W Gruzji najwyższe stawki celne obowiązywały w imporcie napojów i tytoniu $(18,1 \%)$ oraz cukru i wyrobów cukierniczych $(10,6 \%)$. Bardzo niskie cła przywozowe obowiązywały na nasiona oleiste, thuszcze i oleje $(0,1 \%)$, natomiast zerowe na ryby i przetwory rybne oraz bawełnę. $\mathrm{Z}$ kolei w Mołdawii najwyższe cła importowe występowały w przywozie produktów zwierzęcych $(15,1 \%)$, cukru i wyrobów cukierniczych $(15,9 \%)$ oraz produktów mleczarskich $(14,2 \%)$, natomiast najniższe w przywozie ryb - 4\% i zerowe na bawełnę (tabela 4.4). Z analizy średnich stawek celnych stosowanych $w$ imporcie produktów rolno-spożywczych przez poszczególne kraje wynika, że Unia Europejska miała znacząco wyższe cła jedynie na produkty mleczarskie oraz ryby i produkty rybne. 
W praktyce jednak kraje PW objęte były preferencyjnym systemem GSP (Generalized Schemes of Tariff Preferences) ${ }^{176}$, w ramach którego Unia Europejska przyznaje jednostronne preferencje celne krajom rozwijającym się i najmniej rozwiniętym, aby wesprzeć ich rozwój poprzez zapewnienie dodatkowych przychodów z handlu międzynarodowego ${ }^{177}$. Podstawową zasadą ogólnego sytemu GSP jest redukcja stawek celnych na towary wrażliwe o 3,5 pkt proc. i całkowite zniesienie stawek celnych na towary niewrażliwe. Systemem GSP objęte jest około połowy pozycji taryfowych wspólnej taryfy celnej UE odnoszących się do produktów rolno-spożywczych ${ }^{178}$. Oznacza to, że jeszcze przed zawarciem DCFTA unijny import z tych krajów odbywał się na preferencyjnych warunkach, preferencje te były jednak znacznie mniejsze od tych, które przewidziane są w umowach o wolnym handlu.

\subsubsection{Zakres liberalizacji}

Rozwiązania zastosowane w umowie DCFTA zawartej przez UE z państwami PW w zakresie liberalizacji ceł były podobne do tych stosowanych przez UE w innych umowach ${ }^{179}$. Cła w przywozie produktów najmniej wrażliwych były zniesione z dniem wejścia w życie umowy. W wielu grupach produktów przewidziano scenariusz stopniowej liberalizacji. Oznacza to, że eliminacja ceł będzie następowała po pewnym czasie, określanym jako okres przejściowy. W przywozie niektórych bardziej wrażliwych produktów ustanowiono preferencyjne kontyngenty taryfowe. Natomiast produkty najbardziej wrażliwe dla obu stron wyłączono z liberalizacji. Ponadto w umowie DCFTA z Gruzją i Mołdawią

\footnotetext{
${ }^{176}$ Rozporządzenie Parlamentu Europejskiego i Rady (UE) nr 978/2012 z dnia 25 października 2012 r. wprowadzające ogólny system preferencji taryfowych; http://eur-lex.europa.eu/legalcontent/PL/TXT/HTML/?uri=CELEX:02012R0978-20160101 \&qid=1455871043509\&from=PL.

${ }^{177}$ Ł. Ambroziak, M. Błaszczuk-Zawiła, Czy unijne preferencje handlowe maja znaczenie? Przypadek polsko-ukraińskiej wymiany handlowej w latach 2010-2015, „Zeszyty Naukowe Uczelni Vistula" 2016, seria: Ekonomia XI, nr 47(2), s. 19-33.

${ }^{178}$ Ł. Ambroziak, Wplyw umowy o wolnym handlu Unia Europejska-Ukraina na polski import rolno-spożywczy z Ukrainy, „Studia i Prace Wydziału Nauk Ekonomicznych i Zarządzania Uniwersytetu Szczecińskiego" 2017, nr 49/2, s. 11.

${ }^{179}$ Por. M. Bułkowska, Umowy o wolnym handlu UE z Korea Poludniowa, Singapurem $i$ Wietnamem, [w:] I. Szczepaniak (red.), Konkurencyjność polskich producentów żywności i jej determinanty (2), seria „Monografie Programu Wieloletniego 2015-2019”, nr 38, IERiGŻ-PIB, Warszawa 2016, s. 122-145; Ł. Ambroziak, M. Bułkowska, Całościowe Gospodarcze i Handlowe Porozumienie z Kanada (CETA) oraz Transatlantyckie Partnerstwo w dziedzinie Handlu i Inwestycji (TTIP) a konkurencyjność polskich producentów żywności, [w:] I. Szczepaniak (red.), Konkurencyjność polskich producentów żywności i jej determinanty (1), seria „Monografie Programu Wieloletniego 2015-2019”, nr 11, IERiGŻ-PIB, Warszawa 2015, s. 88-113.
} 
Unia Europejska wprowadziła dla niektórych produktów cenę wejścia lub mechanizm przeciwdziałający obchodzeniu ceł, mający na celu zapobieganie nadmiernemu wykorzystywaniu udzielonych preferencji.

\section{Ukraina}

Z dniem 23 kwietnia 2014 roku Unia Europejska zniosła cła na 66\% linii taryfowych obejmujących produkty rolno-spożywcze sprowadzane z Ukrainy. W przypadku $15 \%$ linii taryfowych zerowe stawki celne obowiązywały już wcześniej na mocy klauzuli najwyższego uprzywilejowania (KNU). Oznacza to, że bezcłowy dostęp do rynku unijnego łącznie uzyskało $81 \%$ linii taryfowych obejmujących ukraińskie produkty rolno-spożywcze. W przypadku produktów bardziej wrażliwych założono, że eliminacja ceł będzie następowała w trzech lub siedmiu równych ratach, zwanych okresami przejściowymi. Objęły one niektóre ryby oraz większość przetworów rybnych sprowadzanych z Ukrainy. W przypadku produktów objętych systemem cen wejścia eliminacja ceł dotyczyła tylko komponentu ad valorem. Rozwiązanie takie zastosowano w przywozie niektórych warzyw (m.in. świeżych ogórków i pomidorów), owoców (m.in.: pomarańczy, mandarynek, cytryn, winogron, jabłek i gruszek) oraz przetworów z owoców (m.in. koncentratu winogronowego i moszczu winogronowego).

W przypadku najbardziej wrażliwych produktów, m.in.: zbóż i przetworów zbożowych, wieprzowiny, drobiu, mleka, mleka w proszku, miodu, czosnku, koncentratu winogronowego i jabłkowego, papierosów, przewidziano utworzenie bezcłowych kontyngentów taryfowych (wyrażonych wagowo). Objęto nimi 33 grupy produktów rolno-spożywczych reprezentujących 14\% linii taryfowych w przywozie z Ukrainy (tabela 4.5 ). Kontyngenty te mają charakter roczny i przewidują stałą wielkość importu bądź też jej stopniowe powiększanie w kolejnych 5 latach (począwszy od 2017 roku). Ponadto Ukraina może cały czas korzystać z kontyngentów udzielanych przez UE w ramach zobowiązań wynikających z członkostwa w WTO, które są przeznaczone dla wszystkich krajów trzecich (erga omnes) ${ }^{180}$. Po wyczerpaniu kontyngentu w danym roku import określonego towaru zostaje obciążony cłem (według zewnętrznej taryfy celnej), co obniża konkurencyjność cenową ukraińskich towarów na rynku europejskim.

Ukraina z dniem wejścia w życie umowy DCFTA zniosła cła na 16\% linii taryfowych obejmujących produkty rolno-spożywcze sprowadzane z Unii Europejskiej. Wcześniej zerowe stawki celne obowiązywały w przypadku 19\% takich linii. Oznacza to, że począwszy od 2016 roku bezcłowy przywóz produktów z UE na Ukrainę objął zaledwie 35\% linii taryfowych. Dla trzech grup najbar-

${ }^{180}$ Ł. Ambroziak, Wplyw umowy..., op. cit., s. 9-22. 
dziej wrażliwych produktów wprowadzono kontyngenty taryfowe, tj. na: mięso wieprzowe, mięso drobiowe i drobiowe produkty mięsne oraz cukry (tabela 4.6). Dla pozostałych produktów wprowadzono szereg okresów przejściowych (maksymalnie siedmioletnich). Przewidziano również częściowe obniżki ceł (o 20, 30, 50 lub 60\%) w okresie pięciu, siedmiu lub dziesięciu lat (tabela 4.7).

Tabela 4.5. Bezcłowe kontyngenty taryfowe w przywozie produktów z Ukrainy do UE na mocy umowy DCFTA

\begin{tabular}{|c|c|c|}
\hline Produkty & $\begin{array}{l}\text { Roczna kwota } \\
\text { (w tonach) }\end{array}$ & $\begin{array}{l}\text { Stopień wykorzystania } \\
\text { w } 2016 \text { roku (w proc.) }\end{array}$ \\
\hline Mięso wołowe & 12000 & 0 \\
\hline Mieso wieprzowe & $20000+20000$ & 0 \\
\hline Mięso owcze & $1500-2250$ & 0 \\
\hline Mięso drobiowe i drobiowe produkty mięsne & $16000-20000+20000$ & 100 \\
\hline Mleko, śmietana, mleko zagęszczone i jogurty & $8000-10000$ & 0 \\
\hline Mleko w proszku & $1500-5000$ & 30 \\
\hline Produkty przetworzone z mleka sfermentowanego & 2000 & 0 \\
\hline Masło i produkty mleczarskie do smarowania & $1500-3000$ & 46 \\
\hline Przetworzone produkty $\mathrm{z}$ masła & 250 & 0 \\
\hline Jaja i albuminy & $1500-3000+3000$ & 0 \\
\hline Miód & $5000-6000$ & 100 \\
\hline Czosnek & 500 & 10 \\
\hline Kukurydza cukrowa & 1500 & 1 \\
\hline Grzyby & $500+500$ & 0 \\
\hline Pszenica zwyczajna, mąki i granulki & $950000-1000000$ & 100 \\
\hline Jęczmień, mąka i granulki & $250000-350000$ & 100 \\
\hline Owies & 4000 & 100 \\
\hline Kukurydza, mąka i granulki & $400000-650000$ & 100 \\
\hline Kasza i mączka z jęczmienia & $6300-7800$ & 100 \\
\hline Słód i gluten pszenny & 7000 & 100 \\
\hline Skrobie & 10000 & 19 \\
\hline Cukry & 20070 & 100 \\
\hline Inne cukry & $10000-20000$ & 59 \\
\hline Produkty $\mathrm{z}$ cukru przetworzonego & $2000-3000$ & 17 \\
\hline Produkty z mleka pełnotłustego & $300-500$ & 24 \\
\hline Produkty ze zboża przetworzonego & 2000 & 3 \\
\hline Koncentrat pomidorowy & 10000 & 100 \\
\hline Sok $\mathrm{z}$ winogron $\mathrm{i}$ jabłkowy & $10000-20000$ & 100 \\
\hline Syropy cukrowe & 2000 & 0 \\
\hline Przetwory spożywcze & 2000 & 0 \\
\hline Alkohol etylowy & $27000-100000$ & 7 \\
\hline Otręby, śruta i pozostałości & $16000-21000$ & 43 \\
\hline Papierosy & 2500 & 0 \\
\hline
\end{tabular}

Źródło: opracowanie własne na podstawie umowy DCFTA: Układ o stowarzyszeniu między Unia Europejska i Europejska Wspólnota Energii Atomowej oraz ich państwami członkowskimi, z jednej strony, a Ukraina, z drugiej strony, Dz. Urz. UE, L 161/3 z 29.05.2014, http://eur-lex.europa.eu/legal-content/PL/TXT/PDF/?uri=CELEX:22014A0529(01)\&from=PL (dostęp: 25.09.2017) oraz Zintegrowanej Taryfy Celnej UE (TIRAC 2017), http://ec.europa.eu/ taxation_customs $/$ dds2/taric/taric_consultation.jsp? Lang $=e n \& S i m D a t e=20170101$ (dostep : 28.09.2017). 
Tabela 4.6. Bezcłowe kontyngenty taryfowe w przywozie produktów z UE na Ukrainę na mocy umowy DCFTA

\begin{tabular}{|l|c|}
\hline \multicolumn{1}{|c|}{ Produkty } & Roczna kwota (w tonach) \\
\hline Mięso wieprzowe & 10000 \\
\hline Mięso drobiowe i drobiowe produkty mięsne & $8000-10000$ \\
\hline Cukry & $30000-40000$ \\
\hline
\end{tabular}

Źródto: opracowanie własne na podstawie umowy DCFTA: Układ o stowarzyszeniu między Unia Europejskq... a Ukraina, op. cit.

Tabela 4.7. Redukcja ceł na wybrane produkty rolno-spożywcze UE eksportowane na Ukrainę

\begin{tabular}{|c|c|}
\hline $\begin{array}{l}\text { Etapy redukcji } \\
\text { ceł }\end{array}$ & Produkty \\
\hline Po 1 roku & grzyby, niektóre nasiona (z lucerny, buraki pastewne, brukiew), łuski kakao \\
\hline Po 2 latach & skórki z owoców cytrusowych lub melonów, soki owocowe \\
\hline Po 3 latach & $\begin{array}{l}\text { bydło żywe, owce, kaczki, gęsi, króliki, wołowina, jagnięcina, niektóre gatunki } \\
\text { ryb, niektóre warzywa i owoce, herbata, gluten pszenny, niektóre tłuszcze i oleje, } \\
\text { melasy trzcinowe, wybrane przetwory z owoców i warzyw, różne przetwory } \\
\text { spożywcze (sos sojowy, ketchup), napoje alkoholowe, papierosy }\end{array}$ \\
\hline Po 5 latach & $\begin{array}{l}\text { konie, osły, muły, indyki, perliczki, mięso z kóz, niektóre gatunki ryb, sery, } \\
\text { niektóre warzywa i owoce, kawa, mate, zboża, mąki, niektóre oleje roślinne, } \\
\text { niektóre przetwory rybne, wybrane wina }\end{array}$ \\
\hline Po 7 latach & $\begin{array}{l}\text { mięso drobiowe, niektóre ryby, niektóre produkty mleczarskie, w tym mleko dla } \\
\text { niemowląt, trzcina cukrowa, niektóre przetwory z mięsa i ryb, tytoń }\end{array}$ \\
\hline $\begin{array}{l}\text { Obniżka o } 20 \% \\
\text { w ciągu } 5 \text { lat }\end{array}$ & $\begin{array}{l}\text { tłuszcze i podroby mięsne, niektóre produkty mleczarskie (mleko, śmietana, ma- } \\
\text { sło), miód, kukurydza cukrowa, niektóre owoce (jabłka, morele, wiśnie i czere- } \\
\text { śnie), skrobie, niektóre nasiona (soja, buraki cukrowe, szyszki chmielowe), } \\
\text { makuchy oraz alkohol etylowy }\end{array}$ \\
\hline $\begin{array}{l}\text { Obniżka o } 30 \% \\
\text { w ciągu } 5 \text { lat }\end{array}$ & masło, oleje roślinne \\
\hline $\begin{array}{l}\text { Obniżka o } 50 \% \\
\text { w ciągu } 5 \text { lat }\end{array}$ & niektóre przetwory z ryb \\
\hline $\begin{array}{l}\text { Obniżka o } 60 \% \\
\text { w ciągu } 5 \text { lat }\end{array}$ & niektóre odpady z ryb \\
\hline $\begin{array}{l}\text { Obniżka o } 50 \% \\
\text { w ciągu } 7 \text { lat }\end{array}$ & $\begin{array}{l}\text { świnie żywe, niektóre podroby i tłuszcze zwierzęce, jogurty, serwatka, niektóre } \\
\text { przetwory z mięsa }\end{array}$ \\
\hline $\begin{array}{l}\text { Obniżka o } 20 \% \\
\text { w ciągu } 10 \text { lat }\end{array}$ & niektóre gatunki ryb i owoców morza \\
\hline $\begin{array}{l}\text { Obniżka o } 50 \% \\
\text { w ciagu } 10 \text { lat }\end{array}$ & kiełbasy \\
\hline
\end{tabular}

Źródlo: opracowanie własne na podstawie umowy DCFTA: Uktad o stowarzyszeniu między Unia Europejska ... a Ukraina, op. cit.

Unia Europejska w większym stopniu otworzyła swój rynek na import z Ukrainy, wprowadzając już w 2014 roku jednostronne preferencje. Niemniej jednak zarówno UE, jak i Ukraina zachowały ochronę najbardziej wrażliwych produktów, wprowadzając z obu stron m.in. bezcłowe kontyngenty taryfowe. 
Przez pierwsze lata funkcjonowania kontyngentów taryfowych na towary rolne Ukraina wykorzystywała je w bardzo różnym stopniu. Kilka kontyngentów taryfowych nie zostało w ogóle wykorzystanych.

W 2016 roku Ukraina wykorzystała przyznane jej kontyngenty na: zboża i produkty zbożowe, cukier, miód, koncentrat pomidorowy, sok z winogron i jabłek, a także mięso drobiowe. Nie skorzystała natomiast z kontyngentów na mięso wołowe, wieprzowe czy też mleko. Może to świadczyć o niedostosowaniu towarów ukraińskich do norm i standardów unijnych w zakresie bezpieczeństwa i jakości żywności oraz niskiej konkurencyjności i braku doświadczenia na rynku europejskim. Eksport z Ukrainy towarów rolnych, które już obecnie spełniają normy unijne, jak np. miód naturalny, w szybkim czasie wyczerpuje względnie niskie kontyngenty taryfowe ${ }^{181}$.

\section{Gruzja}

Na mocy umowy DCFTA UE-Gruzja w imporcie Gruzji z UE zniesiono wszystkie należności celne. UE zniosła cła na wszystkie produkty z wyjątkiem czosnku. W przywozie czosnku ustanowiono bezcłowy kontyngent taryfowy w wysokości 220 ton. Poza kontyngentem import czosnku odbywał się po stawce KNU. Dodatkowo w przywozie do UE niektórych owoców i warzyw wprowadzono cenę wejścia ${ }^{182}$, a kolejne piętnaście kategorii produktów zostało objętych mechanizmem przeciwdziałającym obchodzeniu ceł (tabela 4.8). W ramach tego mechanizmu dla każdej kategorii takich produktów przyjęto średnią roczną wielkość przywozu z Gruzji do Unii Europejskiej, określaną jako wartość progowa. W sytuacji, gdy przywóz osiągnie $80 \%$ wartości progowej, Gruzja jest zobowiązana do przedstawienia UE uzasadnienia dotyczącego zdolności do wytworzenia danych produktów przeznaczonych na wywóz do Unii Europejskiej w ilości większej niż określona w umowie. W przypadku braku takiego uzasadnienia UE może zawiesić preferencyjne traktowanie tych produktów.

Gruzja, która posiada słabo rozwinięty sektor rolno-spożywczy oraz jest importerem netto żywności, całkowicie otworzyła swój rynek dla produktów rolno-spożywczych z UE. Unia Europejska zaś zachowała ochronę najbardziej wrażliwych produktów, wprowadzając mechanizm uniemożliwiający bezpodstawne wykorzystanie przyznanych preferencji.

\footnotetext{
${ }^{181}$ J. Piotrowski, Wpływ umowy o wolnym handlu Unii Europejskiej z Ukraina na import polski-wstepna ocena, „Unia Europejska.pl” 2016, nr 6, s. 27-38.

${ }^{182}$ Były to: pomidory, ogórki, karczochy, cukinia, pomarańcze, klementynki, monrealesy i satsumy, mandarynki, tangeryny, tangele, cytryny, winogrona, jabłka, gruszki, morele, wiśnie, czereśnie, nektaryny, brzoskwinie, śliwki, sok winogronowy, koncentrat winogronowy, moszcz gronowy.
} 
Tabela 4.8. Produkty objęte mechanizmem przeciwdziałającym obchodzeniu ceł w przywozie z Gruzji do UE

\begin{tabular}{|l|c|}
\hline \multicolumn{1}{|c|}{ Produkty } & Wartość progowa (w tonach) \\
\hline Mięso wołowe, wieprzowe i z owiec & 4400 \\
\hline Mięso drobiowe & 550 \\
\hline Wyroby mleczarskie & 1650 \\
\hline Jaja w skorupkach & 6600 \\
\hline Jajka i albuminy & 330 \\
\hline Grzyby & 220 \\
\hline Zboża & 200000 \\
\hline Słód i gluten pszenny & 330 \\
\hline Skrobie & 550 \\
\hline Cukry & 8000 \\
\hline Otręby, śruta i inne pozostałości & 2200 \\
\hline Kukurydza cukrowa & 1500 \\
\hline Cukier przetworzony & 6000 \\
\hline Zboża przetworzone & 3300 \\
\hline Papierosy & 500 \\
\hline
\end{tabular}

Źródto: opracowanie własne na podstawie umowy DCFTA: Układ o stowarzyszeniu między Unia Europejska i Europejska Wspólnota Energii Atomowej oraz ich państwami członkowskimi, z jednej strony, a Gruzja, z drugiej strony, Dz. Urz. UE, L 261/4 z 30.08.2014, http://eur-lex.europa. eu/legal-content/PL/TXT/PDF/? uri=CELEX:32014D0494\&from=PL (dostęp: 25.09.2017).

\section{Motdawia}

W umowie DCFTA UE-Mołdawia Unia Europejska zniosła cła na wszystkie produkty rolno-spożywcze, z wyjątkiem: pomidorów, czosnku, winogron, jabłek, śliwek oraz soku i koncentratu winogronowego, na które zostały wprowadzone bezcłowe kontyngenty taryfowe (tabela 4.9). Dodatkowo w przywozie do UE niektórych owoców i warzyw wprowadzono cenę wejścia (ogórki, karczochy, cukinie, pomarańcze, klementynki, monrealesy i satsumy, mandarynki, tangeryny, tangele, cytryny, gruszki, morele, wiśnie, czereśnie, nektaryny, brzoskwinie, moszcz gronowy), a czternaście kategorii produktów zostało objętych mechanizmem przeciwdziałającym obchodzeniu ceł (tabela 4.10).

Tabela 4.9. Produkty objęte rocznym bezcłowym kontyngentem taryfowym w przywozie z Mołdawii do UE

\begin{tabular}{|l|c|}
\hline \multicolumn{1}{|c|}{ Produkty } & Wielkość (w tonach) \\
\hline Pomidory & 2000 \\
\hline Czosnek & 220 \\
\hline Winogrona & 10000 \\
\hline Jabłka & 40000 \\
\hline Śliwki & 10000 \\
\hline Sok i koncentrat winogronowy & 500 \\
\hline
\end{tabular}

Źródto: opracowanie własne na podstawie umowy DCFTA: Układ o stowarzyszeniu między Unia Europejska i Europejska Wspólnota Energii Atomowej oraz ich państwami członkowskimi, z jednej strony, a Republika Mołdawii, z drugiej strony, Dz. Urz. UE, L 260/4 z 30.08.2014, http://eurlex.europa.eu/legal-content/PL/TXT/PDF/? uri $=$ CELEX:22014A0830(01)\&from $=P L$ (dostęp 25.09.2017). 
Tabela 4.10. Produkty objęte mechanizmem przeciwdziałającym obchodzeniu ceł $\mathrm{w}$ przywozie $\mathrm{z}$ Mołdawii do UE

\begin{tabular}{|l|c|}
\hline \multicolumn{1}{|c|}{ Produkty } & Wartość progowa (w tonach) \\
\hline Mięso świń & 4500 \\
\hline Mięso drobiowe & 600 \\
\hline Produkty mleczarskie & 1700 \\
\hline Jaja w skorupkach & 7000 \\
\hline Jajka i albuminy & 400 \\
\hline Pszenica, mąka i granulki & 75000 \\
\hline Jęczmień, mąka i granulki & 70000 \\
\hline Kukurydza, mąka i granulki & 130000 \\
\hline Cukry & 37400 \\
\hline Zboża przetworzone & 2500 \\
\hline Papierosy & 500 ton lub 1 mld sztuk \\
\hline Przetworzone produkty mleczne & 500 \\
\hline Cukier przetworzony & 4200 \\
\hline Kukurydza cukrowa & 1500 \\
\hline
\end{tabular}

Źródlo: opracowanie wlasne na podstawie umowy DCFTA: Uktad o stowarzyszeniu między Unia Europejska ... a Republika Mołdawii, op. cit.

Tabela 4.11. Redukcja ceł na wybrane produkty rolno-spożywcze w przywozie z UE do Mołdawii

\begin{tabular}{|l|l|}
\hline \multicolumn{1}{|c|}{ Kategoria } & \multicolumn{1}{|c|}{ Produkty } \\
\hline $\begin{array}{l}\text { 10-A } \\
\text { (cła znoszone w 10 równych etapach rocz- } \\
\text { nych, począwszy od 1 stycznia roku następ- } \\
\text { nego po dniu wejścia w życie niniejszego } \\
\text { Układu) }\end{array}$ & $\begin{array}{l}\text { podroby wieprzowe solone lub wędzone, mleko } \\
\text { w proszku, przetwory z indyków, kaczek, perliczek, } \\
\text { wołowina peklowana }\end{array}$ \\
\hline $\begin{array}{l}\text { 10-S } \\
\text { (produkty objęte pięcioletnim okresem } \\
\text { zawieszenia ,standstill”, rozpoczynającym } \\
\text { się od dnia 1 stycznia piątego roku następu- } \\
\text { jącego po dniu wejścia w życie niniejszego } \\
\text { Układu) }\end{array}$ & $\begin{array}{l}\text { świeże lub schłodzone podroby wieprzowe, mrożone } \\
\text { wątroby, winogrona, jabłka, brzoskwinie, śliwki, prze- } \\
\text { twory z wołowiny zakonserwowane }\end{array}$ \\
\hline $\begin{array}{l}\text { 3-A } \\
\text { (cła znoszone w 3 równych etapach rocz- } \\
\text { nych, począwszy od dnia 1 stycznia roku } \\
\text { następującego po dniu wejścia w życie } \\
\text { niniejszego Układu) }\end{array}$ & $\begin{array}{l}\text { sery, makarony, musli, płatki zbożowe, gofry, wafle, } \\
\text { nawet zawierające kakao, pomidory zakonserwowane, } \\
\text { groch konserwowy, kukurydza cukrowa konserwowa, } \\
\text { mieszanki warzyw zakonserwowane, mieszanki z so- } \\
\text { ków owocowych }\end{array}$ \\
$\begin{array}{l}\text { 5-A } \\
\text { cła znoszone w } 5 \text { równych etapach rocz- } \\
\text { nych, począwszy od dnia 1 stycznia roku } \\
\text { następującego po dniu wejścia w życie } \\
\text { niniejszego Układu) }\end{array}$ & $\begin{array}{l}\text { niektóre sery (niedojrzewające), pomidory świeże, } \\
\text { cebula, kalafiory i brokuły, kapusta biała i czerwona, } \\
\text { marchew, rzepa, buraki sałatkowe, rzodkiewka, ogórki, } \\
\text { groch, fasola, papryka, cukinia, wiśnie, nektaryny, } \\
\text { truskawki, porzeczki czarne, czerwone, białe i agrest, } \\
\text { maliny, makarony, pieczywo chrupkie, słodkie herbat- } \\
\text { niki, gofry, wafle, sucharki, chleb, bułki, dżemy, gala- } \\
\text { retki z wiśni, truskawek, malin, sok pomidorowy, sok } \\
\text { winogronowy, koncentrat winogronowy, koncentrat } \\
\text { jabłkowy, wina }\end{array}$ \\
\hline
\end{tabular}

Źródto: opracowanie własne na podstawie umowy DCFTA: Układ o stowarzyszeniu między Unia Europejska ... a Republika Mołdawii, op. cit. 
Mołdawia z kolei wprowadziła kontyngenty na unijną wieprzowinę oraz mięso drobiowe (4000 t), produkty mleczarskie (1000 t), przetwory z mięsa $(1700 \mathrm{t})$, cukry (5400 t) oraz cukry przetworzone (640 t). W niektórych grupach produktów, obejmujących około $10 \%$ linii taryfowych, przewidziano stopniową liberalizację ceł, wprowadzając maksymalnie dziesięcioipółletnie okresy przejściowe (tabela 4.11).

W umowie DCFTA z Mołdawią UE przewidziała podobne rozwiązania jak z Gruzją, znosząc wszystkie cła, zachowując jednocześnie ochronę najbardziej wrażliwych produktów, wprowadzając bezcłowe kontyngenty taryfowe, ceny wejścia dla niektórych owoców oraz mechanizm przeciwdziałania obchodzeniu ceł na czternaście kategorii produktów, w tym na mięso wieprzowe i drobiowe, produkty mleczarskie, jaja oraz zboża. Mołdawia zachowała większą ochronę swojego rynku, wprowadzając bezcłowe kontyngenty taryfowe na podstawowe produkty rolno-spożywcze sprowadzane z UE, ponadto dla bardziej wrażliwych produktów wprowadziła szereg okresów przejściowych.

\subsubsection{Bariery pozataryfowe}

W zawieranych przez Unię Europejską umowach o wolnym handlu regulowane są także inne kwestie niż bariery taryfowe, np. normy sanitarne i fitosanitarne (Sanitary and Phitosanitary Standards - SPS). Głównym celem włączenia kwestii regulujących stosowanie tych norm do zawieranych porozumień jest zminimalizowanie negatywnego oddziaływania obowiązujących środków SPS na handel przy jednoczesnym zapewnieniu ochrony życia, zdrowia ludzi, zwierząt oraz roślin. Zawierane przez UE umowy są w tym zakresie bardzo podobne. Odnoszą się one przede wszystkim do takich kwestii, jak: zbliżenie systemu regulacyjnego, uznawanie statusu stron pod względem zdrowia zwierząt i roślin, stosowanie zasady regionalizacji oraz ustanowienie mechanizmu uznawania równoważności środków otrzymywanych przez stronę.

Na mocy każdej z trzech analizowanych umów został powołany Podkomitet ds. Zarządzania Sanitarnego i Fitosanitarnego (Podkomitet SPS), który stanowi pewnego rodzaju platformę służącą wymianie informacji oraz umożliwiającą wypracowanie wspólnego stanowiska w zakresie norm, wytycznych i zaleceń w ramach poszczególnych SPS.

W umowach DCFTA środki SPS odnoszą się do norm w zakresie żywności i dodatków paszowych (tj.: dodatków do żywności, substancji pomocniczych w przetwórstwie, substancji aromatyzujących do żywności, enzymów spożywczych, jak również dodatków paszowych, materiałów paszowych, niepożądanych substancji w paszy) oraz dotyczących dobrostanu zwierząt (ogłuszania 
i uboju zwierząt, transportu zwierząt, chowu zwierząt), a także innych środków, takich jak: chemikalia do odkażania żywności czy hormony wzrostu.

Istotną kwestią regulowaną przez unijne umowy w ramach SPS są warunki i postanowienia dotyczące tymczasowego zatwierdzania przedsiębiorstw wytwarzających produkty pochodzenia zwierzęcego lub roślinnego. Zgodnie $\mathrm{z}$ umową partnerzy uznają kompetencje unijnych instytucji w zakresie kontrolowania i monitorowania zgodności produkcji z unijnymi wymaganiami bezpieczeństwa żywności na podstawie właściwych gwarancji dostarczonych przez stronę bez wcześniejszego przeprowadzania inspekcji na miejscu ${ }^{183}$.

\subsubsection{Reguly pochodzenia}

Reguły pochodzenia (Rules of Origin - RoO) określają kryteria, które muszą zostać spełnione, aby dany produkt został uznany za pochodzący z danego kraju czy regionu, a eksporter mógł korzystać z preferencyjnych stawek celnych. Zgodnie $\mathrm{z}$ charakterem umów DCFTA, tylko produkty pochodzące od jednej ze stron mogą korzystać z preferencji, o ile spełniają określone dodatkowe wymogi.

$\mathrm{W}$ analizowanych trzech umowach przyjęto podobne rozwiązania dotyczące reguł pochodzenia. Za produkty pochodzące $\mathrm{z}$ danego kraju uważa się produkty całkowicie uzyskane $\mathrm{w}$ danym kraju (w tym: produkty roślinne tam zebrane oraz zwierzęta żywe tam urodzone i wyhodowane, produkty pochodzące od żywych zwierząt tam wyhodowanych) oraz produkty uzyskane w danym kraju, zawierające materiały, które nie zostały w pełni tam uzyskane, pod warunkiem, że materiały te zostały poddane wystarczającej obróbce lub przetworzeniu w Unii Europejskiej. RoO uwzględniają również zasadę niewystarczającej obróbki lub przetworzenia, która obejmuje m.in. czynności mające na celu zapewnienie zachowania produktów w dobrym stanie podczas transportu i składowania ${ }^{184}$.

\subsubsection{Oznaczenia geograficzne}

Umowy o wolnym handlu regulują także kwestie związane z prawami własności intelektualnej, w tym ochronę oznaczeń geograficznych (Geographical Indications - GIs). Oznaczeniem geograficznym jest oznaczenie słowne, odno-

\footnotetext{
${ }^{183}$ Por. np. Załącznik VIII do rozdziału 4 Układu o stowarzyszeniu między Unią Europejską i Europejską Wspólnotą Energii Atomowej oraz ich państwami członkowskimi, z jednej strony, a Ukrainą, z drugiej strony, Dz. Urz. UE L 161/3 z 29.05.2014, http://eur-lex.europa.eu/legalcontent/PL/TXT/PDF/?uri=CELEX:22014A0529(01)\&from=PL.

${ }^{184}$ Por. np. Protokół I Dotyczący definicji pojęcia „produkty pochodzące” oraz metod współpracy administracyjnej dołączony do Układu o stowarzyszeniu między Unią Europejską... a Ukrainą, ibid.
} 
szące się bezpośrednio lub pośrednio do nazwy miejsca, miejscowości, regionu lub kraju (terenu), które identyfikuje towar jako stamtąd pochodzący, jeżeli określona jakość, dobra opinia lub inne cechy są przypisywane przede wszystkim pochodzeniu geograficznemu tego towaru. Unia Europejska uznaje dwa rodzaje GIs dla środków spożywczych - chronione nazwy pochodzenia (Protected Designation of Origin - ChnP) i chronione oznaczenia geograficzne (Protected Geographical Indication $-\mathrm{ChOG})^{185}$; podobne kategorie dla win i wyrobów spirytusowych.

Ochrona GIs ma dla unijnych producentów duże znaczenie zarówno gospodarcze, jak i kulturowe, dlatego też w interesie UE leży objęcie tych nazw ochroną również na rynkach międzynarodowych. Według stanu na 27 września 2017 roku w bazie DOOR było zarejestrowanych 1350 produktów spożywczych z oznaczeniami geograficznymi (bez win i wyrobów spirytusowych). Najwięcej nazw chronionych pochodziło z Włoch (291), Francji (243) i Hiszpanii (190). W Polsce zarejestrowanych jest obecnie 28 produktów $(8 \mathrm{ChnP} \text { i } 20 \mathrm{ChOG})^{186}$.

W ramach umów DCFTA tylko UE zapewniła sobie ochronę wybranych GIs dla produktów spożywczych; na rynku ukraińskim dla 812 produktów, mołdawskim -853 i gruzińskim - 805 produktów. W umowach DCFTA z Ukrainą i Gruzją ochroną GIs objęto 6 produktów pochodzących z Polski, tj.: Bryndzę Podhalańską, Oscypek, Wielkopolski ser smażony, Miód wrzosowy z Borów Dolnośląskich, Andruty kaliskie oraz Rogal świętomarciński, natomiast w umowie z Mołdawią 7 produktów - oprócz ww. sześciu, także Wiśnię nadwiślankę.

Państwa Partnerstwa Wschodniego nie zastrzegły żadnego GIs odnoszącego się do produktów spożywczych, ale zapewniły ochronę GIs w kategorii win i napojów spirytusowych. W Unii Europejskiej mają być chronione oznaczenia geograficzne dwóch win ukraińskich (Soniachna Dolyna oraz Novyj Svit ${ }^{187}$, dwóch win mołdawskich - Ciumai/Чумай oraz Romănești oraz osiemnastu win gruzińskich. W trzech omawianych umowach wśród chronionych unijnych GIs znalazły się trzy produkty alkoholowe pochodzące z Polski, tj. Polska wódka, Wódka ziołowa z Niziny Północnopodlaskiej aromatyzowana ekstraktem z trawy żubrowej (,żubrówka”) oraz Polish Cherry („wiśniówka”).

\footnotetext{
${ }^{185}$ Trzecią kategorię stanowią produkty tradycyjne, posiadające oznaczenie Gwarantowana Tradycyjna Specjalność (GTS), których produkcja nie musi być związana z określonym obszarem geograficznym, stąd nie są oficjalnie zaliczane do GIs. W Polsce obecnie zarejestrowanych jest 9 produktów GTS, natomiast w całej UE - 56 .

${ }^{186} \mathrm{http}$ ://ec.europa.eu/agriculture/quality/door/list.html?\&filterReset=true (dostęp: 27.09.2017).

${ }^{187}$ Ponadto Ukraina zastrzegła sobie prawo do stosowania w obrocie handlowym niektórych nazw, które są nazwami obszarów geograficznych na jej terytorium.
} 
Umowy o wolnym handlu zapewniają wysoki poziom ochrony europejskich oznaczeń geograficznych produktów o dużym znaczeniu handlowym, w tym wysokiej jakości win, wódek, serów i szynek, cieszących się uznaniem konsumentów na świecie, zapobiegając ich niewłaściwemu wykorzystaniu na rynkach zagranicznych. Wydaje się jednak, że mają one większe znaczenie w przypadku krajów wysoko rozwiniętych. Pozwalają na odróżnienie produktu i zapewniają o ich wysokiej jakości, co sprzyja poprawie konkurencyjności i zwiększeniu rentowności sprzedaży. Mieszkańcy krajów PW są mniej zamożni, stąd ich popyt na droższe produkty z oznaczeniami GIs prawdopodobnie będzie ograniczony. Większe korzyści ochrona GIs może przynieść gruzińskim i mołdawskim producentom win, na które popyt w UE, w tym w Polsce, systematycznie rośnie.

\subsection{Wpływ umów na konkurencyjność polskich producentów żywności}

Aby ocenić wpływ analizowanych umów handlowych na konkurencyjność polskich producentów żywności, przedstawiono pozycję konkurencyjną poszczególnych państw PW oraz Polski we wzajemnej wymianie handlowej produktami rolno-spożywczymi. W ocenie pozycji konkurencyjnej tych krajów wykorzystano wskaźnik ujawnionych przewag komparatywnych (RCA) ${ }^{188}$.

$\mathrm{Z}$ analizy pozycji konkurencyjnej Polski i Ukrainy we wzajemnym handlu rolno-spożywczym wynika, że Polska posiadała przewagi komparatywne w eksporcie na Ukrainę (RCA > 1) aż w 12 grupach produktów, które stanowiły około 92\% polskiego eksportu rolno-spożywczego na rynek ukraiński (tabela 4.12). Najwyższe wskaźniki RCA odnotowano w eksporcie zwierząt żywych oraz mięsa i podrobów (powyżej 3,0), ale także warzyw, owoców, przetworów z warzyw i owoców oraz przetworów zbożowych i wyrobów cukierniczych. Z kolei producenci ukraińscy byli konkurencyjni na rynku polskim w eksporcie dziesięciu grup produktów, stanowiących 94\% wartości eksportu. Najwyższe wskaźniki RCA uzyskała Ukraina w eksporcie na polski rynek takich produktów, jak: nasiona i owoce oleiste, przetwory z warzyw i owoce oraz tłuszcze i oleje roślinne i zwierzęce, odpady i pasze, oraz zboża. W przypadku pięciu grup produktów przewagi konkurencyjne miała zarówno Polska na rynku ukraińskim, jak i Ukraina na rynku polskim. Były to: produkty mleczarskie, owoce, przetwory z owoców i warzyw, wyroby cukiernicze oraz odpady i pasze dla zwierząt.

Ukraina była konkurencyjna na polskim rynku głównie jako dostawca surowców i półproduktów dla polskich zakładów przemysłu olejarskiego i paszowego. W tych branżach firmy z Ukrainy rywalizowały $\mathrm{z}$ dostawcami także $\mathrm{z}$ innych

${ }^{188}$ Zob. rozdział 2, s. 48-49. 
krajów poza Polską. Można oczekiwać, że większa konkurencja w pozytywny sposób wpłynie na producentów z tych branż. Wyraźny wzrost polskiego importu produktów objętych bezcłowymi kontyngentami (m.in. miodu, koncentratu jabłkowego i pomidorowego oraz kukurydzy) z Ukrainy w latach 2013-2016 wskazuje, że ukraińscy eksporterzy również skorzystali z tych preferencji. Dalsze zwiększanie kontyngentów może jednak okazać się niekorzystne dla polskich producentów zbóż (m.in. pszenicy), szczególnie w dłuższej perspektywie. Obecnie jednak skala importu surowców rolnych, również tych objętych kontyngentami, z Ukrainy jest relatywnie niewielka i nie stanowi realnego zagrożenia dla krajowej produkcji. Z kolei zniesienie ceł na cukierki sprawiło, że stały się one na polskim rynku konkurencyjne cenowo i zaczęły stanowić zagrożenie dla krajowych producentów (szacuje się, że ukraińskie słodycze są nawet o 30-40\% tańsze od polskich) ${ }^{189}$. Aby móc konkurować z tańszymi wyrobami pochodzącymi z Ukrainy, polscy producenci będą zmuszeni obniżyć koszty produkcji, co może niekorzystnie wpłynąć na jakość polskich wyrobów cukierniczych.

W eksporcie do Gruzji Polska posiadała przewagi komparatywne w jedenastu grupach produktów, z czego największe dotyczyły ekstraktów roślinnych, przetworów z owoców i warzyw, przetworów z kakao oraz wyrobów cukierniczych. Z kolei Gruzja posiadała na rynku polskim przewagi komparatywne w pięciu grupach, w tym największe w eksporcie napojów bezalkoholowych i alkoholowych (głównie win) oraz owoców i orzechów. Zarówno Polska na rynku gruzińskim, jak i Gruzja na rynku polskim uzyskiwały przewagi konkurencyjne w eksporcie przetworów z owoców i warzyw.

$\mathrm{W}$ handlu z Mołdawią polscy producenci posiadali przewagi konkurencyjne w eksporcie ośmiu grup produktów, w tym największe w przypadku przetworów z kakao, wyrobów cukierniczych, mięsa i podrobów, przetworów z mięsa i ryb oraz przetworów z owoców i warzyw. $Z$ kolei Mołdawia posiadała na rynku polskim przewagi komparatywne w eksporcie dziewięciu grup produktów, w tym nasion i owoców oleistych, przetworów z owoców i warzyw, napojów bezalkoholowych i alkoholowych (win) oraz zbóż.

Wydaje się, że znacznie mniejszy wpływ na import Polski miały preferencje handlowe udzielone przez UE Mołdawii oraz Gruzji, które są wielokrotnie mniejszymi producentami i eksporterami żywności niż Ukraina. Z Mołdawii wzrósł przywóz do Polski głównie napojów alkoholowych (win i alkoholu etylowego) oraz owoców, np. malin. Z Gruzji z kolei zwiększył się przede wszystkim import win. Oznacza to, że import z obu krajów stanowi raczej uzupełnienie oferty krajowej i nie jest zagrożeniem dla produkcji krajowej. Wydaje

${ }^{189}$ Ł. Ambroziak, Wpływ umowy..., op. cit. 
się, że dalsze możliwości rozwoju polskiego eksportu istnieją na rynku gruzińskim, która jest importerem netto żywności, a jej mieszkańcy są pozytywnie nastawieni do Polski.

Tabela 4.12. Wskaźniki RCA w eksporcie rolno-spożywczym z Polski na Ukrainę, do Gruzji i Mołdawii oraz w eksporcie rolno-spożywczym z Ukrainy, Gruzji i Mołdawii do Polski (średnio w latach 2014-2016) według działów HS

\begin{tabular}{|c|c|c|c|c|c|c|}
\hline \multirow[b]{2}{*}{$\begin{array}{c}\text { Dział } \\
\text { HS }\end{array}$} & \multicolumn{2}{|c|}{$\begin{array}{l}\text { Handel Polski } \\
\text { z Ukrainą }\end{array}$} & \multicolumn{2}{|c|}{$\begin{array}{l}\text { Handel Polski } \\
\text { z Gruzją }\end{array}$} & \multicolumn{2}{|c|}{$\begin{array}{c}\text { Handel Polski } \\
\text { z Mołdawią }\end{array}$} \\
\hline & $\begin{array}{c}\text { RCA } \\
\text { w eksporcie } \\
\text { z Polski } \\
\text { na Ukrainę } \\
\end{array}$ & $\begin{array}{c}\text { RCA } \\
\text { w eksporcie } \\
\text { z Ukrainy } \\
\text { do Polski }\end{array}$ & $\begin{array}{c}\text { RCA } \\
\text { w eksporcie } \\
\text { z Polski } \\
\text { do Gruzji } \\
\end{array}$ & $\begin{array}{c}\text { RCA } \\
\text { w eksporcie } \\
\text { z Gruzji } \\
\text { do Polski } \\
\end{array}$ & $\begin{array}{c}\text { RCA } \\
\text { w eksporcie } \\
\text { z Polski } \\
\text { do Mołdawii } \\
\end{array}$ & $\begin{array}{c}\text { RCA } \\
\text { w eksporcie } \\
\text { z Mołdawii } \\
\text { do Polski } \\
\end{array}$ \\
\hline 01 & 3,55 & 0,04 & 0,12 & 0,00 & 0,28 & 0,00 \\
\hline 02 & 3,08 & 0,06 & 1,10 & 0,10 & 2,30 & 0,00 \\
\hline 03 & 0,11 & 0,01 & 0,06 & 0,00 & 0,51 & 0,00 \\
\hline 04 & 1,50 & 1,90 & 1,43 & 0,00 & 0,85 & 1,88 \\
\hline 05 & 0,60 & 1,03 & 0,90 & 0,00 & 1,58 & 0,00 \\
\hline 06 & 0,39 & 0,12 & 1,77 & 0,00 & 0,93 & 0,00 \\
\hline 07 & 2,36 & 0,84 & 0,08 & 4,96 & 1,65 & 0,04 \\
\hline 08 & 2,20 & 1,56 & 0,85 & 19,46 & 0,27 & 4,18 \\
\hline 09 & 1,34 & 0,05 & 0,13 & 0,51 & 0,66 & 3,07 \\
\hline 10 & 0,03 & 4,93 & 0,00 & 0,00 & 0,00 & 9,70 \\
\hline 11 & 0,48 & 0,64 & 0,52 & 1,75 & 0,22 & 0,00 \\
\hline 12 & 0,17 & 13,22 & 0,10 & 0,38 & 0,24 & 40,52 \\
\hline 13 & 0,43 & 0,22 & 6,34 & 0,00 & 0,55 & 0,00 \\
\hline 14 & 0,75 & 81,85 & 0,68 & 0,00 & 12,12 & 16,87 \\
\hline 15 & 0,07 & 5,46 & 1,18 & 0,00 & 0,05 & 2,43 \\
\hline 16 & 0,24 & 0,00 & 0,40 & 0,00 & 1,79 & 0,00 \\
\hline 17 & 1,33 & 1,43 & 2,22 & 0,00 & 2,56 & 6,24 \\
\hline 18 & 1,70 & 0,22 & 2,25 & 0,00 & 2,62 & 0,76 \\
\hline 19 & 2,09 & 0,26 & 0,90 & 0,00 & 0,27 & 0,07 \\
\hline 20 & 2,36 & 10,13 & 2,27 & 1,96 & 1,73 & 35,27 \\
\hline 21 & 1,17 & 0,41 & 1,77 & 0,14 & 0,67 & 0,32 \\
\hline 22 & 0,37 & 0,70 & 1,13 & 66,42 & 0,10 & 34,78 \\
\hline 23 & 2,28 & 5,31 & 2,21 & 0,00 & 0,59 & 0,57 \\
\hline 24 & 0,10 & 0,02 & 0,06 & 0,00 & 0,02 & 0,59 \\
\hline Ogółem & 1,05 & 2,30 & 1,07 & 4,82 & 0,80 & 5,29 \\
\hline
\end{tabular}

Uwaga: opis działów jak w tabeli 4.3.

Źródło: opracowanie własne na podstawie danych WITS-Comtrade.

Mimo wielu obaw, również w przypadku Ukrainy, wzrost importu nastąpił tylko w przypadku niektórych grup produktów, takich jak miód, koncentrat pomidorowy, koncentrat jabłkowy, na które UE przydzieliła bezcłowe kontyn- 
genty taryfowe. W przypadku produktów, dla których ukraińscy eksporterzy uzyskali bezcłowy dostęp do rynku unijnego w największym stopniu wzrósł import: oleju rzepakowego i słonecznikowego, mrożonych borówek i malin oraz cukierków niezawierających kakao i cukierków czekoladowych. Oznacza to, że udzielenie preferencji celnych poprawiło dostęp do rynku unijnego, w tym polskiego, jedynie dla niektórych grup towarów oraz nie spowodowało realnego zagrożenia dla produkcji krajowej.

Większych efektów tych umów można się spodziewać w perspektywie długookresowej, zwłaszcza że przedsiębiorstwa, szczególnie te związane z produkcją zwierzęcą, potrzebują czasu, żeby przystosować się do standardów i reguł obowiązujących na unijnym rynku. Rozwój nowoczesnego przetwórstwa na Ukrainie może w przyszłości poważnie zagrozić sektorowi rolno-spożywczemu w UE, w tym w Polsce. Ukraińscy producenci rolni i przedsiębiorstwa przemysłu spożywczego będą musieli ponieść koszty dostosowania się do norm i standardów unijnych w dziedzinie przepisów weterynaryjnych, sanitarnych i bezpieczeństwa żywności. To, jak będą przebiegać reformy mające na celu doprowadzenie ukraińskiego ustawodawstwa do zgodności z wymogami unijnymi, będzie zależało nie tylko od kwestii gospodarczo-ekonomicznych, ale też politycznych ${ }^{190}$.

\subsection{Podsumowanie}

Podpisanie umów DCFTA z Unią Europejską otwiera nowe możliwości dla krajowych producentów produktów rolno-spożywczych oraz stwarza możliwości osiągania korzyści w związku z liberalizacją handlu dla obu stron. Umowy te mają działanie długoterminowe, a ich pozytywny efekt jest uzależniony przede wszystkim od tego, czy kraje Partnerstwa Wschodniego rzeczywiście przyjmą zawarte tam regulacje unijne, a potem je wdrożą.

Bliskość geograficzna, więzi kulturowe, społeczne i historyczne powodują, że Polska i Ukraina są dla siebie ważnymi partnerami handlowymi. Pomimo wprowadzenia wielu ułatwień we wzajemnym handlu, w ostatnich latach nastąpił jednak spadek obrotów handlowych między tymi krajami. Możliwość rozwoju eksportu polskich towarów ograniczało głównie osłabienie ukraińskiej waluty oraz kryzys gospodarczy na Ukrainie. Z kolei osłabienie hrywny i obniżka unijnych cel, sprzyjające importowi z Ukrainy, nie spowodowały „zalania” polskiego rynku produktami z Ukrainy. Głównym czynnikiem utrudniającym ukraińskim producentom ekspansję eksportową jest konieczność poniesienia kosztów dostosowania się do norm i standardów unijnych w zakresie przepisów

\footnotetext{
${ }^{190}$ A. Adarov, P. Havlik, Benefits and Costs of DCFTA: Evaluation of the Impact on Georgia, Moldova and Ukraine, The Vienna Institute for International Economic Studies 2016.
} 
sanitarnych i bezpieczeństwa jakościowego żywności. Ponadto najbardziej wrażliwe produkty, których Ukraina jest znaczącym producentem (m.in. zboża), zostały objęte przez Unię Europejską bezcłowymi kontyngentami taryfowymi. Wprawdzie import poza kontyngentem jest możliwy, ale po stawce celnej KNU, co obniża konkurencyjność cenową ukraińskich towarów na rynku europejskim.

Polska sprowadza z Ukrainy przede wszystkim zboża i nasiona oleiste, które stanowią surowiec dla polskiego przemysłu olejarskiego i paszowego. Oznacza to, że główne pozycje w przywozie z Ukrainy mają w większości charakter komplementarny, a nie konkurencyjny dla polskich producentów rolnych i przetwórców. Biorąc jednak pod uwagę potencjał produkcyjny rolnictwa i przemysłu spożywczego Ukrainy, zniesienie ceł (np. na słodycze) lub zwiększenie kontyngentów na niektóre produkty (np. zboża, w tym pszenicę) może w dalszej perspektywie stanowić zagrożenie dla interesów polskich producentów.

Z perspektywy Polski zarówno Gruzja, jak i Mołdawia nie są znaczącymi partnerami handlowymi. Dla wielu polskich firm wejście na rynek gruziński i mołdawski może być jednak częścią strategii dywersyfikacji eksportu, która ma na celu zmniejszenie ich zależności od sprzedaży do państw członkowskich Unii Europejskiej. Systematyczny wzrost polskiego eksportu na rynek gruziński w ostatnich latach może świadczyć o tym, że polskie produkty są konkurencyjne na rynku gruzińskim, a Gruzini przyjaźnie nastawieni do produktów pochodzących z Polski. Polska sprowadza z Gruzji, podobnie jak z Mołdawii, głównie wino oraz orzechy, warzywa i owoce, które stanowią uzupełnienie oferty krajowej. 


\section{Działalność promocyjna jako czynnik konkurencyjności polskich producentów żywności}

\subsection{Wprowadzenie}

W związku z postępującą globalizacją i wzrostem konkurencji na światowym rynku, sam produkt, nawet najwyższej jakości, nie stanowi jeszcze o sukcesie przedsiębiorstwa i jego pozycji na rynku. Ważny jest sposób dotarcia z tym produktem do potencjalnego odbiorcy. Stąd rola działalności promocyjnej i informacyjnej, która staje się coraz ważniejszym czynnikiem konkurencyjności w sektorze żywnościowym.

Zarówno w literaturze przedmiotu, jak i w praktyce działań marketingowych pojęcie „promocja” jest różnie definiowane. W węższym ujęciu oznacza ono zespół działań i środków, za pomocą których przedsiębiorstwo przekazuje na rynek informacje charakteryzujące produkt i/lub firmę, kształtuje potrzeby nabywców, pobudza i ukierunkowuje popyt oraz zmniejsza jego elastyczność cenową. W tym znaczeniu pojęcie ,promocja” nawiązuje do łacińskich wyrazów: promovere i promotio, oznaczających „popieranie”, „sprzyjanie”, „lansowanie”, „pobudzanie”, czyli oddziaływanie na rynek. Z kolei w szerszym ujęciu pojęcie to jest traktowane synonimicznie z terminem „komunikacja marketingowa” lub „polityka komunikacji przedsiębiorstwa z rynkiem”191. Przytaczając powyższe definicje, należy podkreślić, że o ile promocję można traktować jako proces komunikowania się z rynkiem, to nie każda komunikacja jest promocją. Jest nią bowiem tylko taki proces, który wiąże się z realizacją określonych celów rynkowych przedsiębiorstwa i posługuje się określonym zestawem instrumentów wywierających bezpośredni wpływ na aktywizowanie sprzedaży ${ }^{192}$.

Promocję można uznać za pozacenową formę konkurencji. Ma ona na celu skłonienie nabywcy do zakupu lub korzystania z określonych produktów. Promocja to umiejętne dotarcie z właściwą informacją do konkretnej grupy docelowej potencjalnych odbiorców. W tym ujęciu według P. Kotlera promocja obejmuje różne rodzaje czynności, podejmowanych w celu informowania potencjalnych odbiorców o cechach merytorycznych produktu i przekonania ich do jego zakupu. Skuteczność oddziaływania promocji zależy od jej powiązań z pozostałymi dzia-

\footnotetext{
${ }^{191}$ J.W. Wiktor, Promocja. System komunikacji przedsiębiorstwa z rynkiem, Wydawnictwo Naukowe PWN, Warszawa 2006, s. 40.

${ }^{192}$ E. Michalski, Marketing. Podręcznik akademicki, Wydawnictwo Naukowe PWN, Warszawa 2003, s. 299.
} 
łaniami marketingowymi, czyli kształtowaniem produktu, jego ceną i wykorzystywaną siecią sprzedaży (dystrybucją) $)^{193}$.

Rosnąca konkurencja na rynku produktów żywnościowych oraz likwidacja wielu mechanizmów rynkowych Wspólnej Polityki Rolnej, w tym m.in. wspierających konsumpcję, produkcję czy eksport, wymaga zintensyfikowania działań promocyjnych i informacyjnych.

Jednym z podstawowych sposobów realizacji polityki promocyjnej i informacyjnej w Unii Europejskiej jest wspieranie organizacji producentów sektora rolno-spożywczego poprzez współfinansowanie kampanii (programów), których głównym celem jest wzmocnienie wizerunku unijnych produktów żywnościowych, w szczególności w odniesieniu do jakości, wartości odżywczej i bezpieczeństwa żywności oraz zwiększenie wiedzy konsumentów na temat tych produktów, co z kolei przekłada się na wzrost popytu. Ważną rolę we wsparciu promocji żywności odgrywają także działania promocyjno-informacyjne realizowane w ramach PROW 2007-2013 oraz PROW 2014-2020, a także działania w ramach programów wspierających konsumpcję np.: „Mleko w szkole” oraz „Owoce i warzywa w szkole”. Bez skutecznej promocji trudno byłoby producentom żywności osiągać przewagi konkurencyjne na danym rynku.

\subsection{Dzialania promocyjne, ich funkcje, znaczenie oraz cele}

W klasycznym ujęciu promocję definiuje się jako zestaw środków, za pomocą których firma przekazuje na rynek informacje związane z produktem, kształtuje potrzeby konsumentów oraz wpływa na popyt ${ }^{194}$. Początki promocji jako nieodłącznego elementu marketingu były ściśle związane z rolnictwem. Za prekursora marketingu uznaje się C.H. McCormicka, XIX-wiecznego wynalazcę żniwiarki. W swoich badaniach kierował się on wyjątkowym jak na tamte czasy nastawieniem na klienta, wprowadził m.in. badania rynkowe, usługi posprzedażowe, rozróżnienie kanałów dystrybucji oraz politykę cen i promocji ${ }^{195}$. W latach 60. XX wieku takie rozumienie promocji zostało ujęte w koncepcji marketingu 4P (Product, Price, Place, Promotion), w której obok produktu, ceny i dystrybucji, promocja stanowiła czwarty element składowy, tzw. marketingu mix ${ }^{196}$. W tym ujęciu według P. Kotlera promocja obejmuje różne rodzaje czynności, podejmowanych w celu informowania potencjalnych odbiorców o cechach merytorycznych produktu i przekonanie ich do jego zakupu. Skuteczność oddziaływania

\footnotetext{
${ }^{193}$ P. Kotler, Marketing, Wydawnictwo Rebis, Warszawa 2005, s. 594-595.

${ }^{194}$ S. Antczak (red.), Marketing. Wybrane problemy, Akademia Obrony Narodowej, Warszawa 2016, s. 28.

195 J. Dietl, Marketing, PWE, Warszawa 1985, s. 13.

${ }^{196}$ P. Kotler, Marketing, op. cit., s. 31.
} 
promocji zależy od jej powiązań z pozostałymi działaniami marketingowymi, czyli kształtowaniem produktu, jego ceną i wykorzystywaną siecią sprzedaży (dystrybucją). Obejmuje ona koncepcję produktu wytwarzanego i rozprowadzanego do miejsc, w których można go kupić, promowanego w celu powiadomienia o nim potencjalnych nabywców oraz zapewnienia zwrotu kosztów i osiągnięcia zysku ${ }^{197}$.

Chociaż rynek docelowy nie jest częścią marketingu mix, to jednak potrzeby i pragnienia nabywców tworzących go są punktem wyjścia kompozycji poszczególnych składników marketingu mix (rysunek 5.1).

Rysunek 5.1. Zestaw narzędzi marketingu-mix (4P)

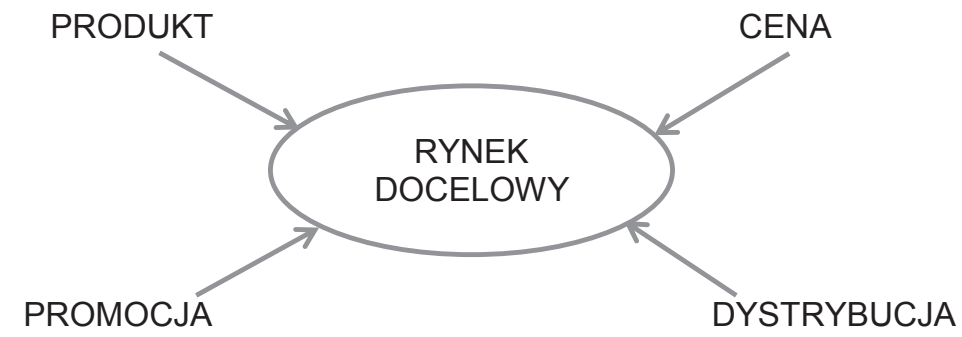

Źródło: opracowanie własne na podstawie E. Michalski, Marketing. Podręcznik akademicki, Wydawnictwo Naukowe PWN, Warszawa 2003, s. 34.

Każde z ww. narzędzi wykorzystywanych do tworzenia dowolnej kompozycji marketingu mix zawiera wiele zmiennych, mających istotny wpływ na zakładane efekty w planowaniu marketingowym, wynikające z koncepcji realizacji strategii działania w danym segmencie rynku ${ }^{198}$. Decyzje dotyczące wykorzystania elementów marketingu mix w działaniach promocyjnych muszą uwzględniać ich wpływ na sposób wyboru kanałów dystrybucji oraz możliwych zachowań nabywców, głównie z rynków docelowych.

W procesie konkurencji na zrównoważonym, dynamicznym rynku chodzi o taki odbiór środków reklamowych, aby w sposób skuteczny dotrzeć do nabywców, utrwalić wiedzę o towarze lub usłudze, zainteresować i skłonić ich do zakupu. Cały przekaz reklamowy nastawiony jest na skuteczne dotarcie do potencjalnego klienta. Przedsiębiorstwa poszukują nowych form i środków konkurencji na danych rynkach, z konkretnym rozpoznaniem potencjału popytowego oraz skłonności akceptacji oferty rynkowej towarów i usług ${ }^{199}$.

\footnotetext{
${ }^{197}$ E. Michalski, Marketing..., op. cit., s. 33.

${ }^{198}$ P. Kotler, Marketing, op. cit., s. 16.

${ }^{199}$ R. Nowacki i M. Strużycki (red.), Reklama w procesach konkurencji, Wydawnictwo Difin SA, Warszawa 2011, s. 41.
} 
W procesach konkurencji rynkowej podstawową rolę odgrywa sposób komunikowania się przedsiębiorstwa z rynkiem, czyli informowania o przedsiębiorstwie i zachęcania do nabywania jego produktów, informowania o tożsamości i pozycji rynkowej firmy, a także o produktach. Działania takie spełniają trzy funkcje ${ }^{200}: 1$ ) informacyjną - dostarczają wiedzy o danym produkcie, jego właściwościach, zastosowaniu; 2) stymulującą - kreują chęć nabycia danego produktu; 3) konkurencyjną - stwarzają pozacenowe instrumenty konkurencji rynkowej. Funkcje te wzajemnie się przenikają i łączą, wspólnie wyrażając główne cele promocji określonych produktów (rysunek 5.2).

Rysunek 5.2. Struktura i wzajemne powiązania podstawowych funkcji promocji

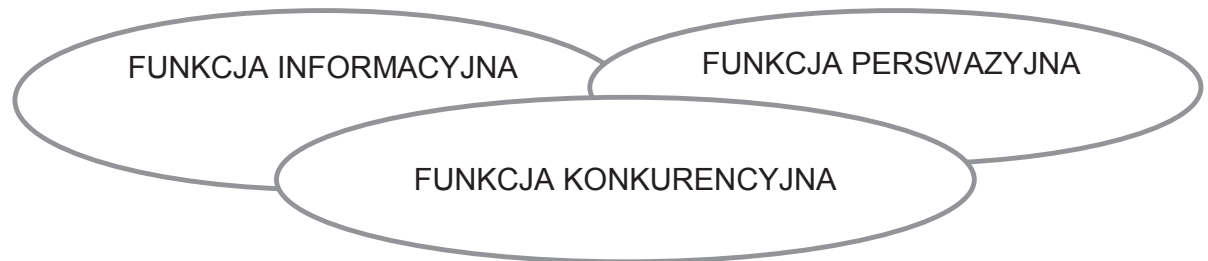

Źródto: opracowanie własne na podstawie S. Antczak (red.), Marketing. Wybrane problemy, Akademia Obrony Narodowej, Warszawa 2016, s. 198.

W innym ujęciu zadaniem promocji jest wywołanie u konsumenta efektu poznawczego i emocjonalnego, umożliwiających podejmowanie decyzji nabycia produktu (rysunek 5.3).

Rysunek 5.3. Przykładowe efekty oddziaływania narzędzi promocji

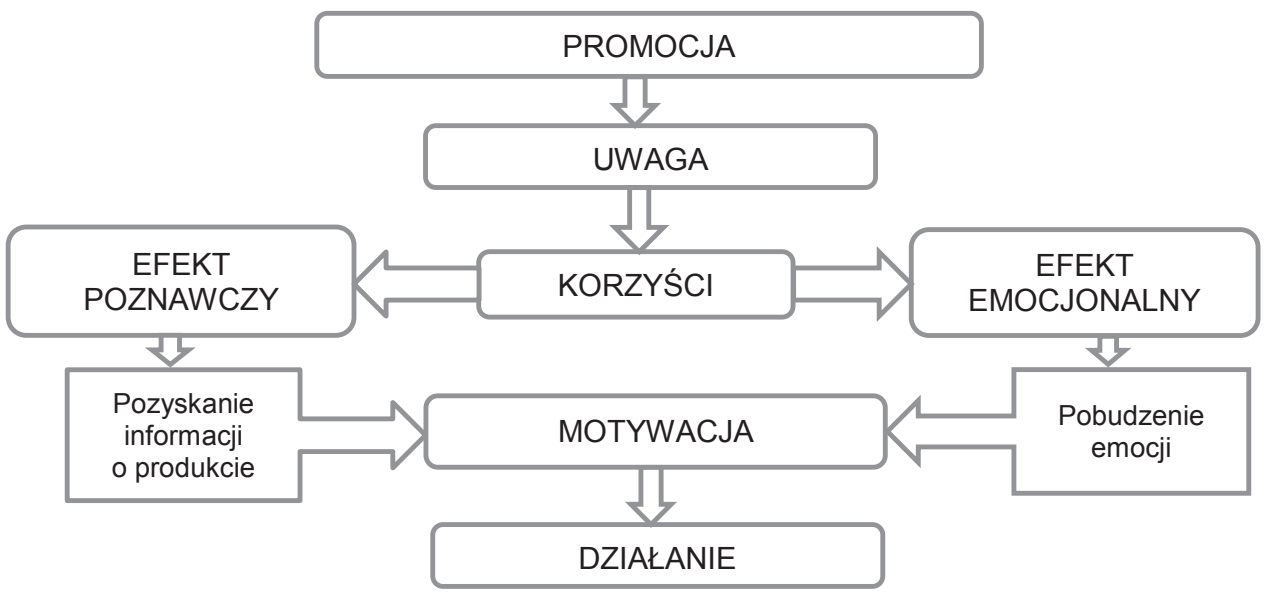

Źródto: opracowanie własne na podstawie S. Antczak (red.), Marketing..., op. cit., s. 199.

${ }^{200}$ S. Antczak (red.), Marketing..., op. cit., s. 198. 
Efekt poznawczy dotyczy pozyskania i zgromadzenia informacji o firmie i jej produktach, a także stworzenia obiektywnego obrazu korzyści możliwych do osiągnięcia. Efekt emocjonalny uzyskuje się dzięki pobudzeniu i wzmocnieniu emocji konsumenta w celu stworzenia oczekiwanego, indywidualnego odbioru produktu ${ }^{201}$. Promocję można więc zdefiniować jako proces stopniowego wpływania na nabywcę. Ilustrują to modele prezentujące poszczególne etapy (tabela 5.1), przez które przechodzi klient/konsument, zanim dokona zakupu. Najważniejsze modele określania promocji to ${ }^{202}$ :

- Model AIDA (Attention, Interest, Desire, Action) - zawiera następujące elementy: zwrócenie uwagi, spowodowanie zainteresowania i chęci posiadania dobra, skłonienie do zakupu. Model ten prezentuje etapy, przez które przechodzi klient, zanim dokona zakupu. W modelu AIDA najistotniejszy jest pierwszy etap, tj. zwrócenie uwagi. Poznanie jest istotne ze względu na konieczność przedstawienia wszystkich walorów oferowanego produktu. Skłonność, która powstaje u nabywcy, poprzedza wykształcenie się konkretnych preferencji. Wzbudzenie chęci posiadania produktu prowadzi do przekonania i zakupu.

- Model Lavidge'a-Steinera - zakłada występowanie sześciu kolejnych etapów oddziaływania promocji, którymi są: świadomość i znajomość - efekty związane $\mathrm{z}$ wiedzą konsumenta, upodobanie i preferencje - efekty związane z emocjonalnym nastawieniem konsumenta do produktu lub marki oraz przekonanie do zakupu i zakup - efekty związane z zachowaniem konsumenta. Zdaniem autorów modelu efekty te muszą następować w opisanej kolejności, ale mogą być bardzo rozciągnięte w czasie, co zależy przede wszystkim od zaangażowania konsumenta w zakup ${ }^{203}$.

- Model DAGMAR (Defining Advertising Goals for Measured Advertising Results) opiera się na założeniu, że promocja stanowi jedną z sił wpływających na konsumenta, której działanie polega na: uświadomieniu odbiorcom ich potrzeb, zrozumieniu przez nich, że potrzeby te mogą zostać zaspokojone przez dany towar lub usługę, a na koniec - działaniu czyli zakupie produktu.

\footnotetext{
${ }^{201}$ S. Antczak (red.), Marketing..., op. cit., s. 198.

${ }^{202}$ H. Górska-Warsewicz, M. Świątkowska, K. Krajewski, Marketing żywności, Wydawnictwo JAK, Warszawa 2013, s. 320-324.

${ }^{203}$ J. Kall, Reklama, PWE, Warszawa 1995, s. 29-30.
} 
Tabela 5.1. Wybrane modele promocji

\begin{tabular}{|c|c|c|c|c|}
\hline $\begin{array}{c}\text { Sposób } \\
\text { oddziaływania } \\
\text { promocji }\end{array}$ & $\begin{array}{c}\text { Postawa } \\
\text { konsumencka }\end{array}$ & $\begin{array}{l}\text { Model } \\
\text { AIDA }\end{array}$ & $\begin{array}{c}\text { Model } \\
\text { Lavidge'a- } \\
\text {-Steinera }\end{array}$ & $\begin{array}{c}\text { Model } \\
\text { DAGMAR }\end{array}$ \\
\hline Informowanie & $\begin{array}{c}\text { faza } \\
\text { poznawcza }\end{array}$ & zwrócenie uwagi & $\begin{array}{c}\text { świadomość } \\
\downarrow \\
\text { wiedza }\end{array}$ & nieświadomość \\
\hline Perswadowanie & $\begin{array}{c}\text { faza } \\
\text { emocjonalna }\end{array}$ & $\begin{array}{l}\text { zainteresowanie } \\
\text { pragnienie } \\
\text { posiadania }\end{array}$ & $\begin{array}{l}\text { sympatia } \\
\text { preferencja } \\
\text { przekonanie }\end{array}$ & przekonanie \\
\hline Przypominanie & $\begin{array}{c}\text { faza } \\
\text { behawioralna }\end{array}$ & $\begin{array}{l}\text { pobudzenie } \\
\text { do działania }\end{array}$ & zakup & działanie \\
\hline
\end{tabular}

Źródło: opracowanie własne na podstawie H. Górska-Warsewicz, M. Światkowska, K. Krajewski, Marketing żywności, Wydawnictwo JAK, Warszawa 2013, s. 322 i P. Kotler, Marketing, Wydawnictwo Rebis, Warszawa 2005, s. 578.

Zachowania konsumentów na rynku koncentrują się wokół zakupów, jednak dla pełniejszego ich poznania sektor nauki nieustannie tworzy kolejne modele uwzględniające wiele nowych uwarunkowań ekonomicznych, psychologicznych i społecznych.

Podstawowym celem promocji jest zwrócenie uwagi na dany produkt, rozbudzenie zainteresowania nim, a w konsekwencji wywołanie chęci posiadania i dokonanie zakupu, czyli stymulowanie sprzedaży ${ }^{204}$. Cele promocji można podzielić na:

- cele o charakterze ekonomicznym - zwane również celami sprzedażowymi, które wytyczają pożądany poziom sprzedaży promowanych produktów lub docelowy ich udział w rynku;

- cele o charakterze komunikacyjnym - dotyczą szerokiego wachlarza działań związanych z producentem, konsumentem i produktem (marką) i dotyczą zmiany stosunku odbiorców promocji do promowanego produktu oraz wzrostu świadomości konsumentów ${ }^{205}$.

Cele promocji powinny być określone w miarę precyzyjnie, tak aby możliwa była weryfikacja stopnia ich realizacji.

${ }^{204}$ H. Górska-Warsewicz, M. Świątkowska, K. Krajewski, Marketing żywności, op. cit., s. 289.

${ }^{205}$ J.W. Wiktor, Promocja..., op. cit., s. 78-83. 


\subsection{Wybrane instrumenty promocji i ich oddziaływanie na odbiorców}

System promocji ma złożoną strukturę. Tworzy ją kombinacja następujących elementów (instrumentów, narzędzi): reklama, sprzedaż osobista, promocja sprzedaży oraz public relations (rysunek 5.4).

Rysunek 5.4. Wybrane instrumenty (narzędzia) promocji

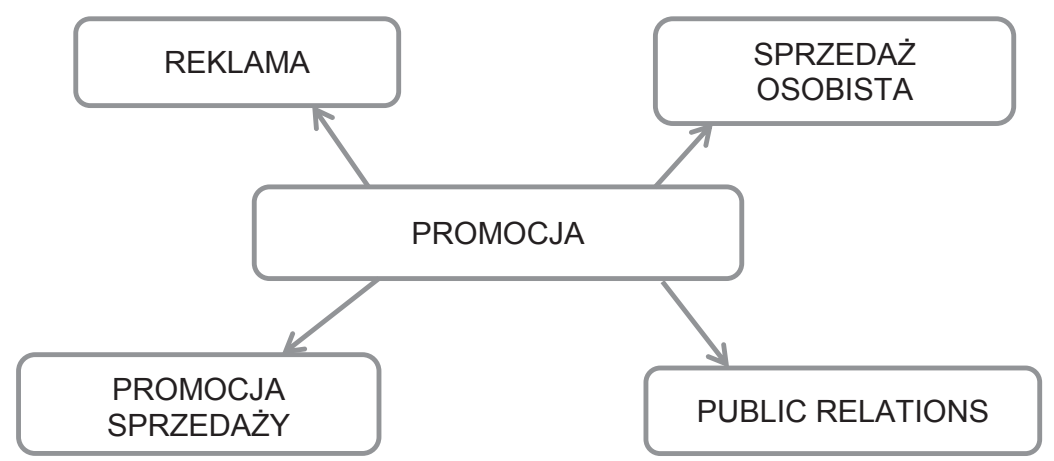

Źródto: opracowanie własne na podstawie S. Antczak (red.), Marketing..., op. cit., s. 201.

Poszczególne instrumenty (narzędzia) promocji, mimo że spełniają zbliżone funkcje, różnią się od siebie pod względem kilku podstawowych kryteriów, tj.:

- charakteru oddziaływania (promocja osobowa i nieosobowa);

- podmiotu odniesienia (nabywcy indywidualni, instytucjonalni, audytorium masowe);

- stopnia dyferencjacji informacji przekazywanych do poszczególnych segmentów rynku - adresatów działań promocyjnych (informacje zindywidualizowane i standardowe, ujednolicone);

- wartości niezbędnych nakładów (wymaganych przez daną formę komunikacji);

- elastyczności działania (instrumenty elastyczne, zapewniające natychmiastowe, bezpośrednie sprzężenie komunikacyjne oraz instrumenty o dużym stopniu usztywnienia);

- horyzontu czasowego oddziaływania (zróżnicowanie okresu ujawniania się efektów promocji ${ }^{206}$.

Najbardziej widocznym narzędziem promocji jest reklama. Stanowi ona podstawowy instrument systemu komunikacji marketingowej. P.D. Bennett reklamę określa jako „każdą płatną formę prezentacji i promocji idei, dobra lub

${ }^{206}$ J.W. Wiktor, Promocja..., op. cit., s. 54. 
usługi określonej przez sponsora"207. Reklama umożliwia komunikowanie się przedsiębiorstwa $\mathrm{z}$ dużą populacją nabywców jednocześnie i powtórzenie tej samej wiadomości wiele razy, tak aby nabywca ją zapamiętał. Może ona promować nazwę podmiotu, znak firmowy, wizerunek firmy, produkt, jego markę czy cechy użytkowe. Główne cele reklamy to ${ }^{208}$ :

- informowanie potencjalnych odbiorców o występowaniu na rynku nowych produktów oraz usług i kierowanie w ich kierunku uwagi potencjalnych konsumentów/klientów (reklama pionierska);

- przekonywanie konsumentów/klientów do zakupu poprzez ukazywanie skali korzyści wynikających z faktu nabycia określonego produktu lub dokonania zakupu w określonej firmie w stosunku do konkurencji (reklama konkurencyjna);

- przypominanie i utrwalanie w pamięci odbiorców pozytywnego wyobrażenia o firmie lub produkcie (reklama utrwalająca).

Można wyróżnić następujące środki przekazu reklamy: targi, wystawy, plakaty, tablice, banery, telewizja, radio, Internet, gazety, poczta, środki transportu, gadżety, broszurki informacyjne, pokazy, degustacje, próbki.

Sprzedaż osobista to kolejny instrument promocji, związany z prezentowaniem oferty produktowej danego podmiotu w toku bezpośredniej rozmowy sprzedawcy z potencjalnym nabywcą, w celu doprowadzenia do sfinalizowania transakcji ${ }^{209}$. Sprzedaż osobista stanowi przeciwieństwo marketingu masowego, który polega na komunikacji poprzez mass media. Rozwój nowych technologii umożliwia dotarcie do każdego klienta osobno i ułatwia mierzenie rezultatów przeprowadzonej promocji. Zastosowanie sprzedaży osobistej znajduje uzasadnienie tylko w połączeniu z innymi elementami promocji, zwłaszcza z reklamą i promocją sprzedaży ${ }^{210}$.

Promocja sprzedaży (inaczej akwizycja) to wszelkiego rodzaju działania zwiększające atrakcyjność produktu, skierowane do końcowych nabywców bądź pośredników. Według Amerykańskiej Rady Agencji Aktywizacji Sprzedaży jest to działalność marketingowa, w której wykorzystywane są różnorodne bodźce mające na celu stworzenie programów sprzedaży skierowanych do konsumentów, handlowców lub innych nabywców ${ }^{211}$.

\footnotetext{
${ }^{207}$ P.D. Bennett, Dictionary of Marketing Terms, American Marketing Association, Chicago 1995.

${ }^{208}$ J. Altkorn (red.), Podstawy marketingu, Instytut Marketingu, Kraków 2000.

${ }^{209}$ J. Altkorn (red.), Leksykon marketingu, PWE, Warszawa 1998, s. 234.

${ }^{210}$ M.P. Murawski, Znaczenie promocji $w$ działalności marketingowej przedsiębiorstwa, $\mathrm{Wy}-$ dawnictwo Promotor, Warszawa 2010, s. 55.

${ }^{211}$ T. Sztucki, Promocja, reklama, aktywizacja sprzedaży, AW Placet, Warszawa 1995, s. 120.
} 
Public relations jest specyficzną formą promocji, która ma na celu upowszechnianie pozytywnego wizerunku firmy, produktu czy też jakiegoś przedsięwzięcia w środowisku zewnętrznym, czyli w świadomości konsumentów, dostawców, partnerów rynkowych i innych podmiotów ${ }^{212}$. Do narzędzi wykorzystywanych w ramach public relations zaliczamy m.in.: imprezy, przemówienia, przyznane nagrody, publikacje, materiały pisemne i multimedialne.

Instrumenty promocji różnią się efektywnością na poszczególnych etapach gotowości do zakupu. Reklama i public relations odgrywają największą rolę na etapie budowy świadomości. Na zrozumienie klienta podstawowy wpływ ma reklama i sprzedaż osobista, zaś na przekonanie konsumenta do zakupu zwykle wpływa sprzedaż osobista. Zamknięcie transakcji podlega wpływom sprzedaży bezpośredniej i promocji sprzedaży. Ponowienie zamówienia odbywa się zwykle pod wpływem sprzedaży osobistej i w pewnym stopniu reklamy przypominającej ${ }^{213}$.

W procesie promocji wykorzystywane są różne typy nośników, za pomocą których komunikat dociera do uczestników rynku. Poszczególne nośniki mają różny zakres oddziaływania - zarówno czasowy, jak i przestrzenny. W zależności od typu nośnika wyróżnia się komunikację: bezpośrednią (mowa, gesty, mimika), pośrednią z wykorzystaniem pisma (papier, ekran, płótno, katalog, folia, tynk itp.), telefonu, faksu, e-maila (czat, forum dyskusyjne), listu reklamowego, komunikatora internetowego oraz komunikację masową z wykorzystaniem pozycji wydawniczych, telewizji, kina, radia, prezentacji zewnętrznej (Outdoor), Internetu $^{214}$. Wykorzystując różne narzędzia oddziaływania, próbuje się wpływać na świadomość i zachowania nabywców poprzez zwrócenie uwagi i wzbudzenie zainteresowania produktem, firmą i marką oraz wywołanie pragnienia i chęci nabycia produktu, a także pobudzenie do działania (podjęcia decyzji zakupu). Nośniki treści komunikatów promocji mają różne właściwości, dlatego różne są kryteria ich praktycznego stosowania przez podmioty gospodarcze. Wybór danego nośnika warunkowany jest najczęściej skutecznością jego oddziaływania, efektywnością stosowania, zasięgiem działania oraz potrzebami podmiotów rynkowych.

Ocena skuteczności i efektywności działań promocyjnych jest zagadnieniem złożonym, wieloaspektowym i trudnym do zbadania. Różne narzędzia promocji w odmiennym stopniu wpływają na osiąganie celów promocji, zarówno jeśli chodzi o skalę potencjalnego wpływu, jak i horyzont czasowy, w którym

\footnotetext{
${ }^{212}$ V. Smid, Encyklopedia promocji i reklamy, Wydawnictwo PSB, Kraków 2001, s. 87.

${ }^{213}$ S. Antczak (red.), Marketing..., op. cit., s. 203-206.

${ }^{214}$ Ibid.
} 
się ujawniają ${ }^{215}$. Uogólniając, można stwierdzić, iż działania promocyjne są skuteczne wówczas, gdy przedsiębiorstwo realizuje cele promocji, a klient dokonuje zakupu promowanego produktu.

\subsection{Promocja produktów rolno-spożywezych a Wspólna Polityka Rolna}

Wspólna Polityka Rolna UE przewiduje wsparcie działań promocyjnych i informacyjnych prowadzonych zarówno na rynku wewnętrznym UE, jak i na rynkach państw trzecich w odniesieniu do produktów rolnych i metod ich produkcji, a także w odniesieniu do niektórych produktów spożywczych wytworzonych w oparciu o produkty rolne. W tym celu wspierana jest działalność promocyjna i informacyjna, która ma służyć zwiększeniu stopnia przejrzystości rynku oraz kształtowaniu preferencji nabywców.

Działania promocyjne i informacyjne realizowane w ramach WPR powinny sprzyjać w szczególności pogłębianiu wiedzy konsumentów o zaletach unijnych produktów żywnościowych i wysokich standardach ich produkcji oraz o unijnych systemach jakości, w celu zapewnienia lepszej ich rozpoznawalności. Działania te powinny ponadto wpływać na wzrost spożycia tych produktów, a także na większy ich udział w rynku państw trzecich. W przypadku poważnych zakłóceń na rynku, utraty zaufania konsumentów lub innych szczególnych problemów, działania promocyjne i informacyjne realizowane w ramach WPR powinny pomagać w przywracaniu normalnych warunków rynkowych i wzmacniać działania realizowane przez państwa członkowskie ${ }^{216}$. Pomoc finansową na te działania można uzyskać $\mathrm{z}$ budżetu unijnego w ramach mechanizmu WPR „Wsparcie działań promocyjnych i informacyjnych na rynkach wybranych produktów rolnych" na realizację kampanii promocyjno-informacyjnych. O dofinansowanie takich kampanii mogą ubiegać się organizacje zrzeszające producentów z danej branży, a także grupy producentów z danego działu produkcji sektora rolno-spożywczego.

W celu zapewnienia skuteczności realizowanych działań informacyjnych i promocyjnych działania te powinny być opracowane w ramach programów (kampanii) promocyjnych i informacyjnych. Uczestnictwo w tych działaniach (kampaniach) umożliwia organizacjom branżowym uzyskanie zwrotu maksymalnie $85 \%$ kwoty netto kosztów faktycznie poniesionych na realizację działań

\footnotetext{
215 J.W. Wiktor, Promocja ..., op. cit., s. 98.

${ }^{216}$ Rozporządzenie Parlamentu Europejskiego i Rady (UE) nr 1144/2014 z dnia 22 października 2014 r. w sprawie działań informacyjnych i promocyjnych dotyczących produktów rolnych wdrażanych na rynku wewnętrznym i w państwach trzecich oraz uchylające rozporządzenie Rady (WE) nr 3/2008, Dz. Urz. UE L 317/56 z 4.11.2014.
} 
objętych kampanią w przypadku programów mających na celu przywrócenie normalnych warunków wywołanych poważnymi zakłóceniami na rynku oraz przywrócenie utraconego zaufania konsumentów $(80 \%$ - w przypadku prostych programów skierowanych na rynek krajów trzecich i dla programów, w których uczestniczy wiele państw, składanych przez co najmniej dwie organizacje pochodzące z co najmniej dwóch państw członkowskich, skierowanych na rynek wewnętrzny i rynek krajów trzecich oraz $70 \%$ - w przypadku prostych programów, złożonych przez jedną lub kilka organizacji z tego samego kraju i skierowanych na rynek wewnętrzny). Programy te powinny służyć pogłębieniu wiedzy konsumentów na temat zalet produktów rolno-spożywczych wytwarzanych na terenie UE i zwiększeniu popytu na nie poprzez wzmocnienie wizerunku produktu, w szczególności w odniesieniu do jego jakości, wartości odżywczych, bezpieczeństwa środków spożywczych oraz metod produkcji. Działania wspierane przez Komisję Europejską (KE) nie mogą jednak być ukierunkowane na konkretną markę, znak towarowy czy firmę, ani też zachęcać do konsumpcji produktu ze względu na jego określone pochodzenie ${ }^{217}$. Działania promocyjne muszą służyć przede wszystkim wzmocnieniu pozycji unijnych produktów żywnościowych na rynku globalnym, zwiększeniu popytu na promowane produkty, a co za tym idzie na uzyskaniu przewag konkurencyjnych nad konkurentami.

Oprócz ww. działań promocyjno-informacyjnych prowadzonych na rynku produktów rolno-spożywczych i współfinansowanych przez Unię Europejską, ważną rolę we wsparciu promocji odgrywają także fundusze promocji, działania promocyjno-informacyjne realizowane w ramach PROW 2007-2013 Działanie: „Działania informacyjne i promocyjne” oraz PROW 2014-2020 Działanie: „Systemy jakości produktów rolnych i środków spożywczych", jak również działania w ramach programów wspierających konsumpcję, np.: „Mleko w szkole” oraz „Owoce i warzywa w szkole”.

Ustawa o funduszach promocji produktów rolno-spożywczych ${ }^{218}$ powołała dziewięć odrębnych funduszy promocji: mleka, mięsa wieprzowego, mięsa wołowego, mięsa drobiowego, mięsa końskiego, mięsa owczego, ryb, ziarna zbóż i przetworów zbożowych oraz owoców i warzyw. Celem tych funduszy jest promowanie i wspieranie spożycia polskich produktów rolno-spożywczych zarówno na rynkach krajowych, jak i na rynkach europejskich. Zgromadzone w poszczególnych funduszach środki są wykorzystywane m.in. do prowadzenia kampanii informacyjnych i promocyjnych mających na celu wspieranie konku-

\footnotetext{
${ }^{217}$ Rozporządzenie Parlamentu Europejskiego i Rady (UE) nr 1144/2014..., op. cit.

${ }^{218}$ Obowiązująca od 1 lipca 2009 roku Ustawa z dnia 22 maja 2009 roku o funduszach promocji produktów rolno-spożywczych (Dz.U. z 2009 r., nr 97, poz. 799).
} 
rencyjności polskich producentów poprzez promowanie polskich produktów żywnościowych, informowanie o ich jakości i innych zaletach.

Działania informacyjne i promocyjne realizowane w ramach programu PROW 2007-2013 wynikały z rozporządzenia Rady (WE) nr 1698/2005 ${ }^{219}$, zgodnie z którym wspierane były grupy producentów realizujące działalność informacyjną i promocyjną prowadzoną na rzecz promocji produktów wytwarzanych w systemach jakości żywności oraz zwiększenia zainteresowania konsumentów tematyką jakości żywności, jej specyficznymi właściwościami i zaletami. O wsparcie mogły ubiegać się grupy producentów wytwarzających produkty wysokiej jakości w ramach następujących systemów: Chroniona Nazwa Pochodzenia (ChNP), Chronione Oznaczenie Geograficzne (ChOG), Gwarantowana Tradycyjna Specjalność (GTS), Rolnictwo ekologiczne, Integrowana Produkcja Roślin, Jakość Tradycja oraz Quality Meat Program (QMP) ${ }^{220}$.

Program PROW 2014-2020 kontynuuje działania promocyjne i informacyjne, wcześniej rozpoczęte w ramach programu PROW 2007-2013. Celem programu jest zwiększenie uczestnictwa rolników w unijnych i krajowych systemach jakości oraz wsparcie działań informacyjnych i promocyjnych produktów wysokojakościowych, produkowanych w systemach jakości ${ }^{221}$.

Produkty objęte unijnymi systemami jakości i systemami jakości uznanymi przez państwa członkowskie (takimi, jak ekologiczne metody produkcji, znaki graficzne produktów rolnych wysokiej jakości, specyficzne dla rejonów najbardziej oddalonych), kwalifikujące się do objęcia działaniami informacyjnymi i promocyjnymi, zawierają wyjątkową wartość dodaną i warunkują producentom przewagi rynkowe.

Ważnym programem funkcjonującym w Polsce od czasu akcesji do UE, promującym konsumpcję mleka w szkołach, jest program „Mleko w szkole”, mający na celu wsparcie spożycia mleka i jego przetworów w placówkach oświatowych oraz kształtowanie właściwego modelu konsumpcji wśród dzieci i młodzieży. Program ten na stałe wpisał się w codzienne funkcjonowanie większości placówek oświatowych na terenie całego kraju ${ }^{222}$. W ramach tego pro-

\footnotetext{
${ }^{219}$ Rozporządzenie Rady (WE) nr 1698/2005 z dnia 20 września 2005 r. w sprawie wsparcia rozwoju obszarów wiejskich przez Europejski Fundusz Rolny na rzecz Rozwoju Obszarów Wiejskich (EFRROW) z późn. zm., Dz. Urz. UE L 227/1 z 21.10.2005.

${ }^{220}$ Sprawozdanie z działalności Agencji Rynku Rolnego w 2015 roku, Warszawa 2016.

${ }^{221}$ Rozporządzenie Parlamentu Europejskiego i Rady (UE) nr 1305/2013 z dnia 17 grudnia 2013 r. w sprawie wsparcia rozwoju obszarów wiejskich przez Europejski Fundusz Rolny na rzecz Rozwoju Obszarów Wiejskich (EFRROW) i uchylające rozporządzenie Rady (WE) nr 1698/2005, z późn. zm., Dz. Urz. UE L 347/487 z 20.12.2013.

${ }^{222}$ Sprawozdanie z działalności Agencji Rynku Rolnego w 2012 roku, Warszawa 2013.
} 
gramu dzieci i uczniowie spożywają mleko białe i smakowe o różnej zawartości tłuszczu, twarożki, sery i jogurty. Celem tego programu jest kształtowanie dobrych nawyków żywieniowych u dzieci poprzez promowanie spożycia mleka i przetworów mlecznych.

Innym programem promującym konsumpcję owoców i warzyw wśród dzieci i młodzieży, wspieranym z budżetu UE, jest program „Owoce i warzywa w szkole". Uczniowie otrzymują w ramach tego programu co najmniej dwa razy w tygodniu (w ciągu roku szkolnego): świeże owoce (jabłka, gruszki, truskawki, borówki amerykańskie), świeże warzywa (marchewkę, paprykę słodką, rzodkiewki, kalarepę, pomidorki koktajlowe), soki owocowe, warzywne mieszane. Podstawowym celem tego programu jest m.in. trwała zmiana nawyków żywieniowych u dzieci poprzez zwiększenie udziału owoców i warzyw w ich codziennej diecie na etapie, na którym kształtują się nawyki żywieniowe oraz propagowanie zdrowej, zbilansowanej diety i wzrost świadomości społecznej w tym zakresie.

Unijny system promocji jest elementem polityki horyzontalnej, obejmuje prawie wszystkie działy produkcji sektora rolno-spożywczego, podkreślając szczególne cechy unijnych produktów żywnościowych (jakość, bezpieczeństwo żywności, aspekty zdrowotne, znakowanie, szczególne metody produkcji itd.). Uzupełnia on krajowe inicjatywy wspierające lub pobudzające prywatne i publiczne działania na rzecz promocji na szczeblu państw członkowskich.

\subsection{Dzialania promocyjne i informacyjne wspierające polskich producentów żywności}

W okresie od akcesji Polski do UE do końca 2016 roku KE zatwierdziła 35 polskich kampanii promujących produkty rolno-spożywcze (tabela 5.2). Na powyższe działania wydatkowano $283,5 \mathrm{mln}$ zł, z czego $172,6 \mathrm{mln}$ zł pochodziło z budżetu UE, a pozostałe nakłady to wkład własny organizacji branżowych producentów rolnych, środki z funduszy promocji oraz budżetu krajowego ${ }^{223}$.

\footnotetext{
${ }^{223}$ Od 1 grudnia 2015 r. obowiązują zapisy rozporządzenia Parlamentu Europejskiego i Rady (UE) nr 1144/2014, w których zawarto nowe zasady dotyczące polityki promującej produkty rolne i rolno-spożywcze. Główne zmiany dotyczą: (1) zwiększenia unijnego poziomu finansowania (do $70 \% \mathrm{w}$ przypadku programów prostych realizowanych na rynku wewnętrznym UE, do $80 \%$ dla programów prostych realizowanych na rynkach krajów trzecich i w przypadku programów, w których uczestniczy wiele państw oraz do 85\% dla programów kryzysowych) pozostałą część wydatków ponoszą wyłącznie organizacje proponujące; (2) zniesienia współfinansowania kampanii ze środków budżetu krajowego; (3) prowadzenia jednoetapowego procesu wyboru programów przez KE; (4) rozszerzenia listy produktów objętych promocją (przede wszystkim postawiono nacisk na przetworzone produkty rolno-spożywcze i produkty
} 
Największe wsparcie działań promocyjnych i informacyjnych w analizowanym okresie otrzymała branża mięsna (wieprzowina, wołowina, drób) - 40,8\% ogółu wydatkowanych środków w ramach tego działania, gdzie zrealizowano jedenaście kampanii, a cztery są realizowane. Na drugim miejscu znalazła się branża owocowo-warzywna - 22,7\% (zrealizowano sześć kampanii, a dwie są w trakcie realizacji), w dalszej kolejności: branża mleczarska - 14,6\% (zrealizowano trzy kampanie), produkty regionalne i tradycyjne - 8,0\% (zrealizowano dwie kampanie), produkty ekologiczne $-5,4 \%$ (zrealizowano jedną kampanię, jedna jest $\mathrm{w}$ trakcie realizacji), makarony - 5,1\% (zrealizowano jedną kampanię, jedna jest w trakcie realizacji), olej rzepakowy - 2,6\% (zrealizowano jedną kampanię, jedna jest $\mathrm{w}$ trakcie realizacji) oraz miód i produkty pszczele - $2 \%$ (zrealizowano jedną kampanię) - wykres 5.1.

Wykres 5.1. Wsparcie w ramach mechanizmu WPR „Wsparcie działań promocyjnych i informacyjnych na rynkach wybranych produktów rolnych" w Polsce w wybranych branżach sektora rolno-spożywczego, łącznie w latach 2005-2016 (w mln zł) oraz liczba kampanii

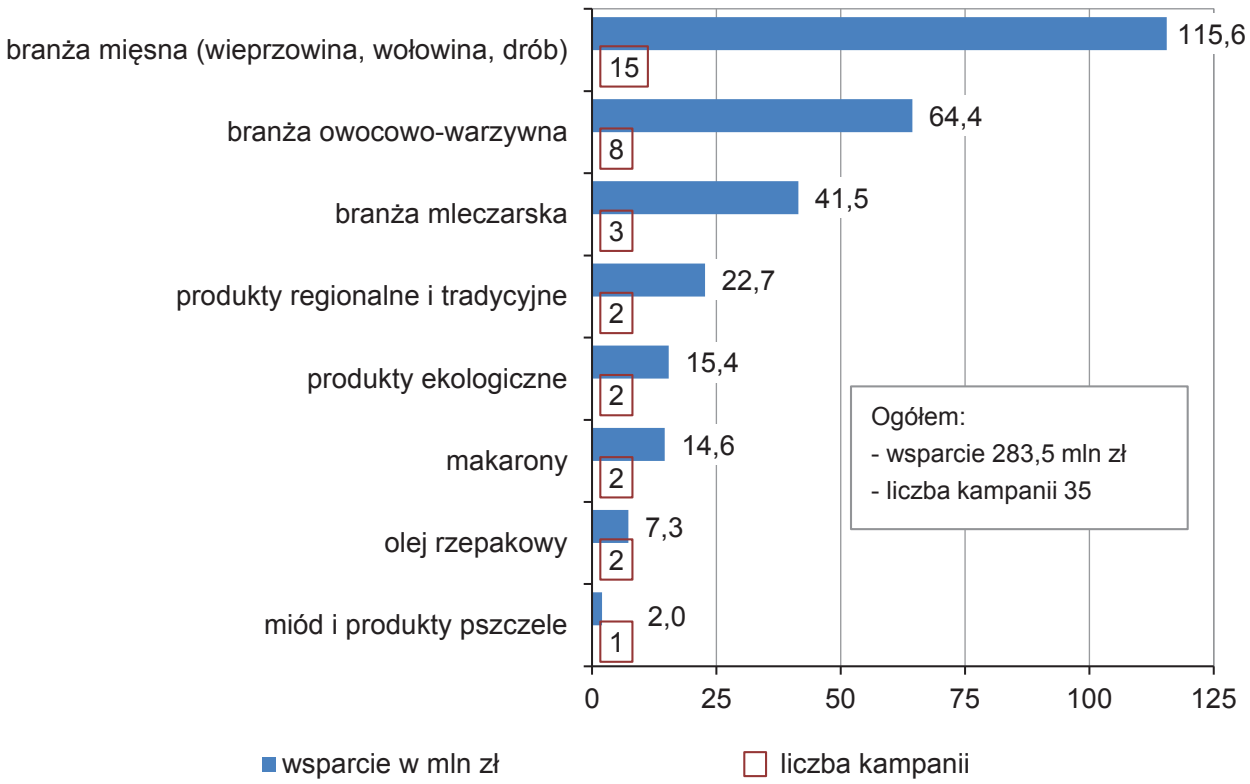

Źródto: opracowanie własne na podstawie danych Agencji Rynku Rolnego (ARR).

uznane przez europejskie systemy jakości); (5) wprowadzenia unijnego rocznego programu prac; (6) włączenia do grupy beneficjentów organizacji producentów lub ich zrzeszeń oraz innych organów sektora rolno-spożywczego, których celem i przedmiotem działalności jest promocja i informowanie o produktach rolnych. 


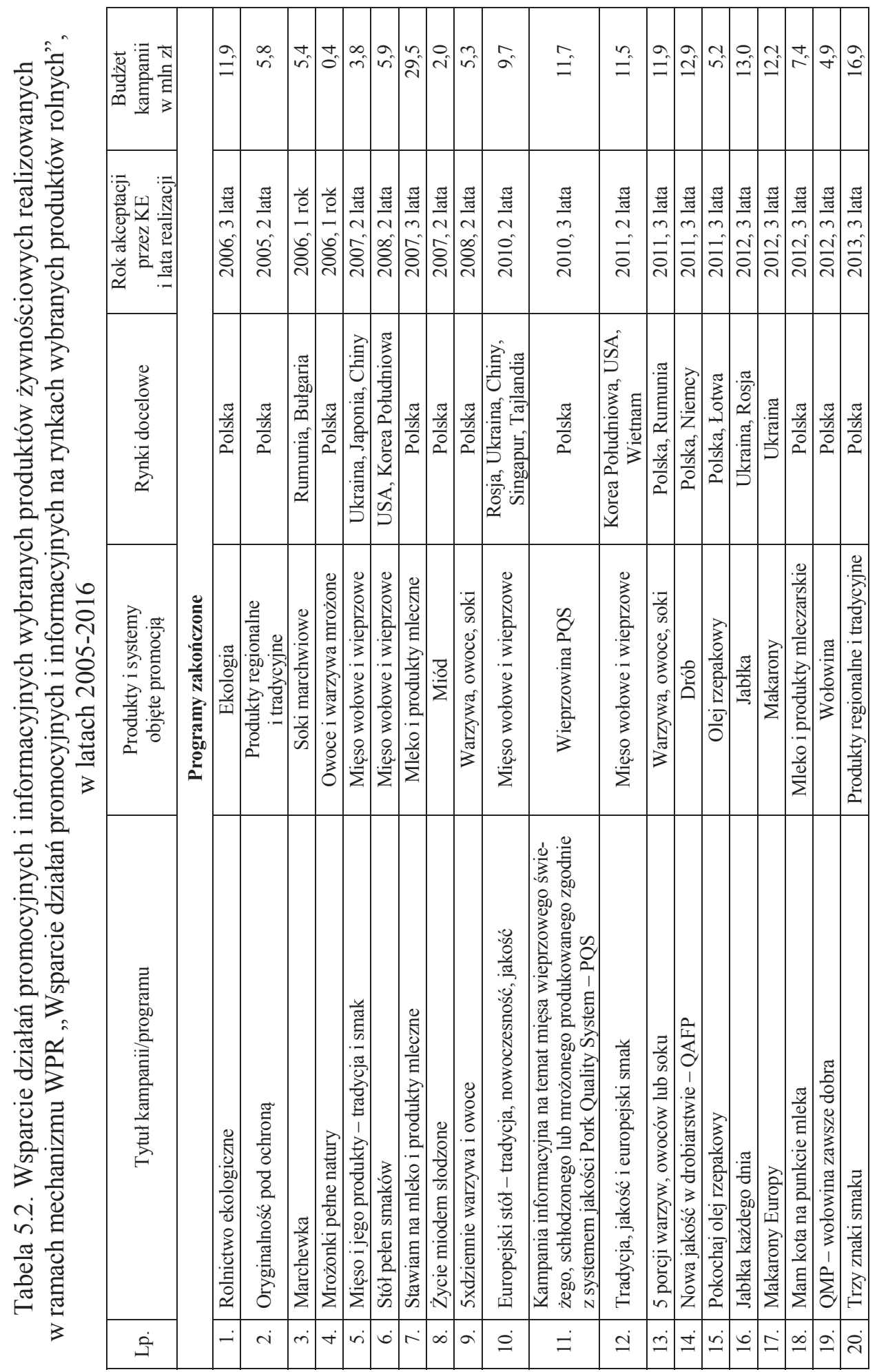




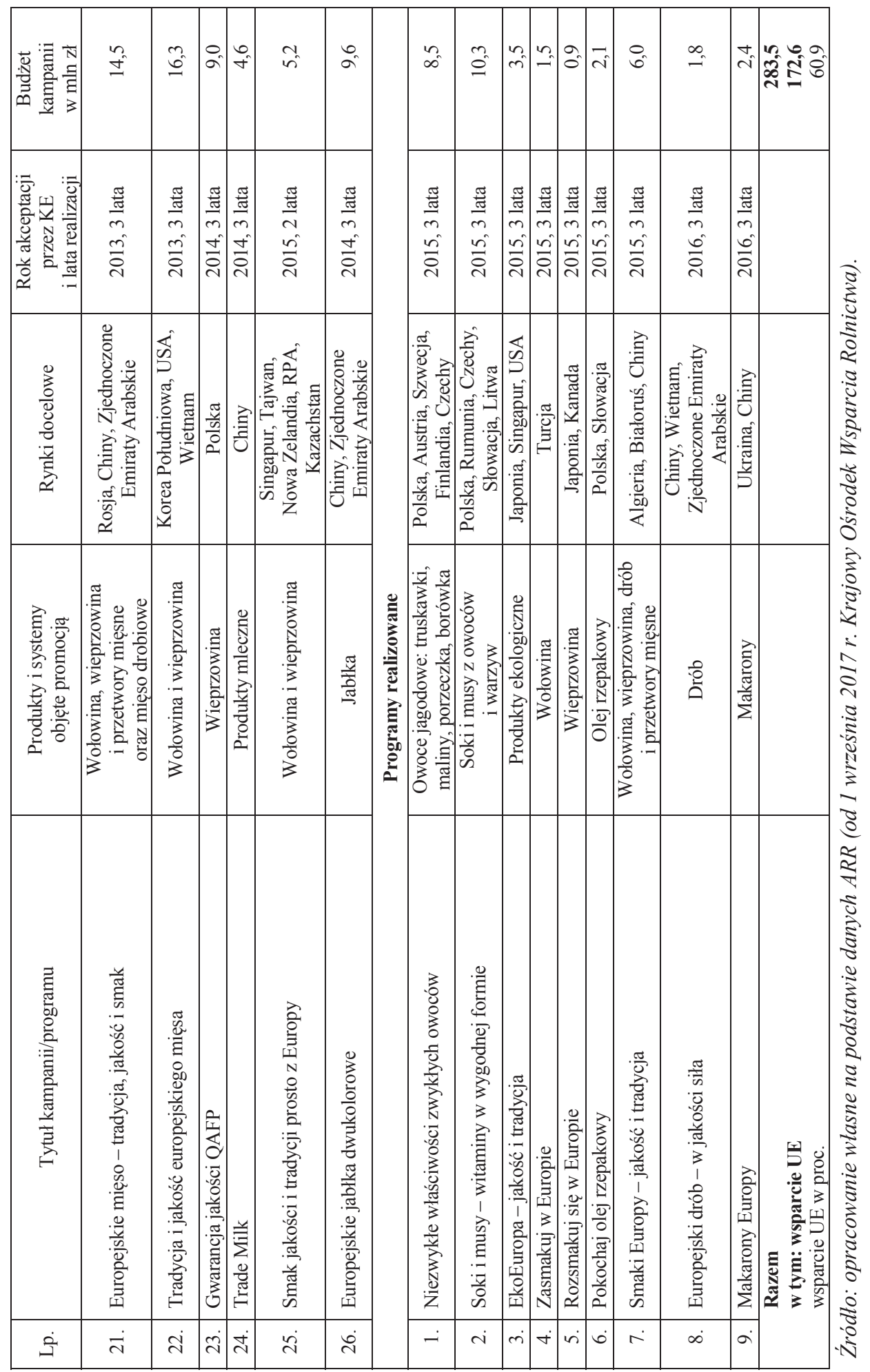


Działania promocyjne i informacyjne produktów żywnościowych realizowane w ramach mechanizmu WPR „Wsparcie działań promocyjnych i informacyjnych na rynkach wybranych produktów rolnych" mogą być prowadzone odrębnie na rynku wewnętrznym UE i na rynkach krajów nienależących do UE. Do końca 2016 roku na działania promocyjno-informacyjne żywności realizowane tylko na rynku polskim przeznaczono $104,8 \mathrm{mln} \mathrm{zł}$ (tj. 37\% tych środków), zaś na rynku UE - 56,3 mln zł $(20 \%)^{224}$. Były to przede wszystkim działania promocyjno-informacyjne, które służyły zwiększeniu wiedzy odbiorców na temat produktów żywnościowych, tj. wzmocnieniu ich pozytywnego wizerunku, poinformowaniu o walorach smakowych i jakości promowanych produktów, rozpowszechnianiu wiedzy o sposobie ich produkcji.

W analizowanym okresie na rynku polskim przeprowadzono 17 kampanii informacyjnych i/lub promocyjnych sektora rolno-spożywczego (tabela 5.2). Były to kampanie ukierunkowane głównie na edukację społeczeństwa z zakresu systemów jakości żywności, oznaczeń produktów regionalnych i tradycyjnych oraz promujące polskie produkty posiadające unijne oznaczenia jakości: Chroniona Nazwa Pochodzenia (ChNP), Chronione Oznaczenie Geograficzne (ChOG) i Gwarantowana Tradycyjna Specjalność (GTS), a także produkty ekologiczne. Inne programy promowały spożycie mleka i produktów mleczarskich, miodu, oleju rzepakowego, a także owoców i warzyw. Kampanie te przeprowadzane były podczas konferencji, seminariów, targów, na festynach, jarmarkach oraz piknikach. Organizowano również warsztaty kulinarne i spotkania połączone $\mathrm{z}$ degustacją potraw. W Internecie publikowane były ulotki informacyjne, tworzono strony internetowe promujące dane przedsięwzięcie, w TV emitowano reklamy, a w czasopismach pojawiały się informacje o programach. Wobec dynamicznie rosnącej konkurencji na rynku konsumenci oczekują jasnych i wyczerpujących informacji na temat jakości oraz pochodzenia produktów rolno-spożywczych, ich właściwości, metod produkcji, wartości odżywczych itp., stąd ogromna rola takich kampanii.

Pozostałe 43\% wydatkowanych środków (122,4 mln zł) przeznaczono na promocję żywności na rynkach krajów pozaunijnych ${ }^{225}$. Dotychczas kampanie promocyjne przeprowadzono w 18 krajach i odnosiły się one do promocji mięsa i przetworów mięsnych (wołowina, wieprzowina, drób) ${ }^{226}$, jabłek (Ukraina, Rosja, Chiny, Zjednoczone Emiraty Arabskie), produktów mleczarskich (Chiny),

\footnotetext{
${ }^{224}$ Obliczenia własne na podstawie tabeli 5.2.

225 Ibid.

${ }^{226}$ Promocja mięsa i przetworów mięsnych na rynkach: Algierii, Białorusi, Chin, Japonii, Kanady, Kazachstanu, Korei Południowej, Nowej Zelandii, Rosji, RPA, Singapuru, Tajlandii, Tajwanu, Turcji, Ukrainy, USA, Wietnamu, Zjednoczonych Emiratów Arabskich.
} 
makaronu (Ukraina i Chiny) oraz produktów ekologicznych (Japonia, Singapur i USA). Kampanie promocyjno-informacyjne prowadzone na ww. rynkach, upowszechniając wiedzę o wysokich standardach produkcji żywności w Polsce i Unii Europejskiej oraz promując jej jakość, oryginalność i walory smakowe, przyczyniły się pośrednio do wzrostu eksportu europejskich produktów żywnościowych (w tym polskich) na rynki zagraniczne.

Dzięki prowadzonym działaniom promocyjnym odbiorcy kampanii mogli nie tylko zdobyć wiedzę, ale także mieli szansę osobiście przekonać się o niepowtarzalnych walorach tych produktów podczas degustacji. Wynikiem tak kompleksowych działań był wzrost rozpoznawalności promowanych produktów. Kampanie przeprowadzone na rynkach pozaunijnych, głównie mięsa i przetworów mięsnych oraz jabłek i makaronów, miały na celu zwiększenie eksportu promowanych produktów oraz pogłębienie wiedzy odbiorców na temat bogatej tradycji, doświadczenia oraz standardów produkcji unijnych produktów żywnościowych, systemach jakości i bezpieczeństwie żywności. Jak wynika z przeprowadzonych analiz handlu zagranicznego, cele te zostały osiągnięte ${ }^{227}$.

Ze środków wsparcia skierowanych na promocję w ramach Programu PROW 2007-2013, Działanie „Działania informacyjne i promocyjne” do polskich przedsiębiorców sektora rolno-spożywczego trafiło 17,4 $\mathrm{mln}$ zł. Z kolei zgodnie z zatwierdzonym przez Komisję Europejską w grudniu 2014 roku Programem Rozwoju Obszarów Wiejskich (PROW) 2014-2020 w ramach Działania „Systemy jakości produktów rolnych i środków spożywczych" do końca 2016 roku do Agencji Rynku Rolnego (instytucji administrującej tym mechanizmem) wpłynęło około 2,4 tys. wniosków o wsparcie na łączną kwotę 140,6 $\mathrm{mln} \mathrm{zf}^{228}$.

Od początku realizacji programu „Mleko w szkole” dzieci uczęszczające do szkół i przedszkoli spożyły około 548 tys. ton mleka i jego przetworów, a na jego realizację wypłacono około 1,5 $\mathrm{mld} \mathrm{z}^{229}$. Od roku szkolnego 2007/2008 Polska jest liderem wśród krajów UE w realizacji tego programu. Ilość mleka i przetworów mlecznych dostarczanych do placówek oświatowych i kwota środków finansowych pozyskiwana przez Polskę z budżetu UE jest większa niż w państwach UE-15, w których program ten jest realizowany od ponad 20 lat (takich jak: Francja, Wielka Brytania, Niemcy czy Szwecja) ${ }^{230}$.

Na realizację programu „Owoce i warzywa w szkole” w okresie od roku szkolnego 2009/2010 do 31 grudnia 2016 roku przeznaczono 409,5 mln zł.

\footnotetext{
${ }^{227}$ Zob. rozdział 2, s. 54-66.

${ }^{228}$ Sprawozdanie z działalności Agencji Rynku Rolnego w 2016 roku, Warszawa 2017.

${ }^{229}$ Ibid.

${ }^{230}$ Strona internetowa http://www.arr.gov.pl/mleko-w-szkole (dostęp: 23.10.2017).
} 
W okresie ośmiu lat realizacji tego programu, do końca II semestru roku szkolnego 2016/2017, dzieciom ze szkół podstawowych udostępniono bezpłatnie blisko $378 \mathrm{mln}$ porcji owoców i warzyw ${ }^{231}$.

\subsection{Podsumowanie}

Obserwując rynek żywnościowy w Polsce, wyraźnie widać, że skuteczna i efektywna promocja jest istotnym narzędziem kształtowania konkurencyjności. Do końca 2016 roku na promocję produktów rolno-spożywczych realizowaną w ramach mechanizmu WPR „Wsparcie działań promocyjnych i informacyjnych na rynkach wybranych produktów rolnych" Polska wydatkowała około 283,5 $\mathrm{mln}$ zł, z czego 172,6 mln zł pochodziło z budżetu UE (wydatki te dotyczyły 35 kampanii promocyjnych). Natomiast na działania informacyjne i promocyjne realizowane w ramach programu PROW 2007-2013 (i jego kontynuacji programu PROW 2014-2020), mające na celu podniesienie wiedzy społeczeństwa z zakresu systemów jakości żywności, wydatkowano dotychczas około 17,4 mln zł. Ważną rolę w kształtowaniu dobrych nawyków żywieniowych, a zarazem promocję żywności wśród uczniów odegrały programy edukacyjne prowadzone wśród dzieci i młodzieży w szkołach: „Owoce i warzywa w szkole” oraz „Mleko w szkole”, które zostały wsparte kwotą odpowiednio: $409 \mathrm{mln}$ zł i około 1,5 mld zł. Środki wydatkowane przez Polskę po akcesji do UE w ramach WPR na wsparcie działań promocyjnych i informacyjnych żywności to jeszcze niewiele w porównaniu z innymi krajami UE, jednak najwięcej spośród nowych państw członkowskich.

Rzetelne informacje dotyczące specyfiki i zalet produktów żywnościowych, kierowane do różnych docelowych grup konsumentów, nie tylko wzbudzają zainteresowanie kupujących i zachęcają producentów do przestrzegania określonych standardów jakościowych, ale pomagają także rozwijać rynek tych produktów. Informacje te wpływają $\mathrm{m}$.in. na zwiększenie popytu na promowane produkty, a w efekcie wzrost ich sprzedaży, poszerzenie wiedzy konsumentów i wzrost ich zaufania do tych produktów, ale także na rozszerzenie międzynarodowych kontaktów handlowych, tj. zdobycie nowych rynków zbytu i zwiększenie asortymentu sprzedawanych produktów.

Obecnie podstawowym celem działań promocyjnych staje się podnoszenie świadomości konsumentów na temat jakości unijnych produktów rolno-spożywczych, co powinno skutkować zwiększeniem ich sprzedaży na rynkach światowych, w tym wyraźnym wzmocnieniem międzynarodowej pozycji konkurencyjnej polskich producentów żywności.

${ }^{231}$ Ibid. 
W związku z postępującą globalizacją i liberalizacją światowego handlu żywnością zwiększa się znaczenie promocji produktów rolno-spożywczych na rynkach zagranicznych. Działania promocyjno-informacyjne ułatwiają zawieranie kontaktów handlowych z odbiorcami zagranicznymi, a także dostarczają im wiedzy o oferowanych produktach. Aktualnie polskie produkty rolno-spożywcze są obecne na wszystkich kontynentach, jednak potrzeba zdobywania coraz to nowych rynków zbytu wymusza realizację przemyślanych strategii promocyjnych, opartych na wiedzy i badaniach, dostosowanych do docelowych odbiorców.

Promocja jest swojego rodzaju inwestycją i przyczynia się do rozwoju promowanych branż i podmiotów. Bezpośredni wpływ działań promocyjno-informacyjnych na wielkość sprzedaży produktów żywnościowych jest jednak trudny do jednoznacznego określenia. Wynika to z równoległego prowadzenia różnych działań marketingowych, ich odsuniętego w czasie wpływu na wielkość sprzedaży oraz oddziaływania czynników zewnętrznych, niezależnych od producentów, takich jak: koniunktura gospodarcza, działania konkurencji itp. 


\section{Postęp biologiczny w rolnictwie i jego wpływ na konkurencyjność producentów rolnych}

\subsection{Wprowadzenie}

Do istotnych zmian i procesów, które zachodzą w rolnictwie wielu krajów w ostatnim ćwierćwieczu można zaliczyć:

- wzrost produkcji, zwiększenie produkcyjności rolnictwa i efektywności wykorzystania nakładów,

- marginalizację (kurczenie się) gospodarczej roli rolnictwa w gospodarce narodowej i gospodarce lokalnej,

- nasilenie konkurencyjności międzynarodowej i międzysektorowej,

- narastanie wrażliwości konsumentów w sferze jakości i bezpieczeństwa żywności przy zwiększaniu siły rynkowej wielkich sieci detalicznych handlu żywnością,

- wzrost znaczenia postępu rolniczego, wiedzy i niematerialnych form kapitału w procesach produkcyjnych i w funkcjonowaniu rolnictwa,

- wzrost wielofunkcyjności rolnictwa i pozarolniczych form gospodarowania na obszarach wiejskich oraz uświadomienie potrzeby oparcia rozwoju rolnictwa na koncepcji rozwoju zrównoważonego,

- słabnięcie społecznego i politycznego poparcia dla polityki protekcjonizmu, subsydiowania i interwencjonizmu rolniczego ${ }^{232}$.

W omawianym okresie rolnictwo rozwijało się na tyle szybko, że w skali światowej było zdolne nadążać za wzrostem efektywnego popytu na żywność. Chociaż w dalszym ciągu około $800 \mathrm{mln}$ ludzi na świecie jest dotkniętych niedożywieniem i nie ma poczucia bezpieczeństwa żywnościowego, to sytuacja wyżywieniowa w krajach wyżej rozwiniętych została rozwiązana, a w większości krajów rozwijających się uległa poprawie ${ }^{233}$. Rolnictwo krajów uprzemysłowionych znacznie powiększyło zdolności wytwórcze przez procesy modernizacji, wzrost stosowania nakładów pochodzenia przemysłowego, zastosowanie postępu biologicznego, specjalizację produkcji, koncentrację i kooperację z sektorami zaopatrzenia, przemysłu i handlu. W krajach wysoko rozwiniętych nowoczesne, rynkowo zorientowane i subsydiowane gospodarstwa rolne są w stanie wytwarzać produkcję znacznie przewyższającą zapotrzebowanie rynku wewnętrznego.

\footnotetext{
${ }^{232}$ M. Adamowicz, Teoretyczne uwarunkowania rozwoju rolnictwa z uwzględnieniem procesów globalizacji i międzynarodowej integracji, „Roczniki Nauk Rolniczych. Seria G” 2008, t. 94, z. 2. ${ }^{233}$ Ibid.
} 
Z kolei w krajach rozwijających się dzięki wykorzystaniu postępu biologicznego, wdrażaniu nowoczesnych technologii produkcji oraz wykorzystaniu efektów innych rodzajów postępu rolniczego uzyskano zwiększenie produkcji rolnej, a w niektórych krajach nawet pojawiły się nadwyżki eksportowe. Nadal jednak aktualne jest pytanie: czy w przyszłości rozwój rolnictwa i wynikający z niego wzrost produkcji rolnej umożliwi zaspokojenie rosnących potrzeb żywnościowych oraz jaka jest rola w tym rozwoju postępu, a szczególnie postępu biologicznego, i w jaki sposób postęp biologiczny wpływa na efektywność produkcji roślinnej i zwierzęcej?

\subsection{Uwarunkowania wzrostu zapotrzebowania na żywność i pokrycia potrzeb żywnościowych}

Z ogólnoświatowego bilansu zapotrzebowania na żywność wynika potrzeba wzrostu produkcji rolnej. W wielu krajach jednak dalszy wzrost produkcji rolnej jest hamowany przez ograniczony popyt wewnętrzny oraz ograniczone możliwości eksportowe, co wzmacnia długookresową tendencję do obniżania się realnych cen surowców rolnych. Ta sytuacja może się zmienić w nadchodzących dziesięcioleciach w związku z prognozowanym przyrostem liczby ludności na świecie oraz rosnącymi dochodami ludności, a także malejącymi wskaźnikami wzrostu produktywności rolnictwa. W związku z rozwojem nowych technologii produkcji rolniczej pojawiły się nowe problemy i zagrożenia, zwłaszcza natury środowiskowej i zdrowotnej. Zmiany klimatu, degradacja środowiska, wzrastająca konkurencja ze strony sektorów nierolniczych o grunty i wodę, wzrastające ceny energii i innych nakładów przemysłowych oraz rosnące koszty wdrażania innowacji stwarzają problemy rozwojowe, powiązane ze wzrostem poziomu ryzyka i niepewności. Istnieją zatem przesłanki, by prognozować, że ceny żywności przestaną spadać i przyjmą trendy wzrostowe. Stawia to pod znakiem zapytania słuszność dotychczasowych dążeń do ograniczania produkcji w krajach wysoko rozwiniętych i subsydiowania producentów, co z kolei wpływa na niższy poziom cen żywności na rynku globalnym, przyczyniając się równocześnie do osłabiania możliwości rozwojowych rolnictwa w krajach rozwijających się.

Mając na względzie globalne potrzeby wyżywieniowe, szacuje się, że dla zaspokojenia wzrastającego popytu produkcja żywności tylko w pierwszych 30 latach XXI wieku powinna się powiększyć o około 50\% w sektorze zbóż i aż o $85 \%$ w sektorze mięsnym. Do tego trzeba dodać wzrastające zapotrzebowanie 
na wytwarzane przez rolników surowce przeznaczane na cele energetyczne, co już obecnie przyczynia się do wzrostu cen ${ }^{234}$.

\subsubsection{Zasoby Ziemi a liczba ludności}

Oceniając możliwości wzrostu produkcji rolniczej w skali świata, należy zauważyć, że na skutek zachodzących procesów urbanizacji zmniejsza się, pozostająca do rolniczego wykorzystania, powierzchnia użytków rolnych. W skali globu udział gruntów ornych wynosi obecnie zaledwie 3\% powierzchni ziemi (wykres 6.1).

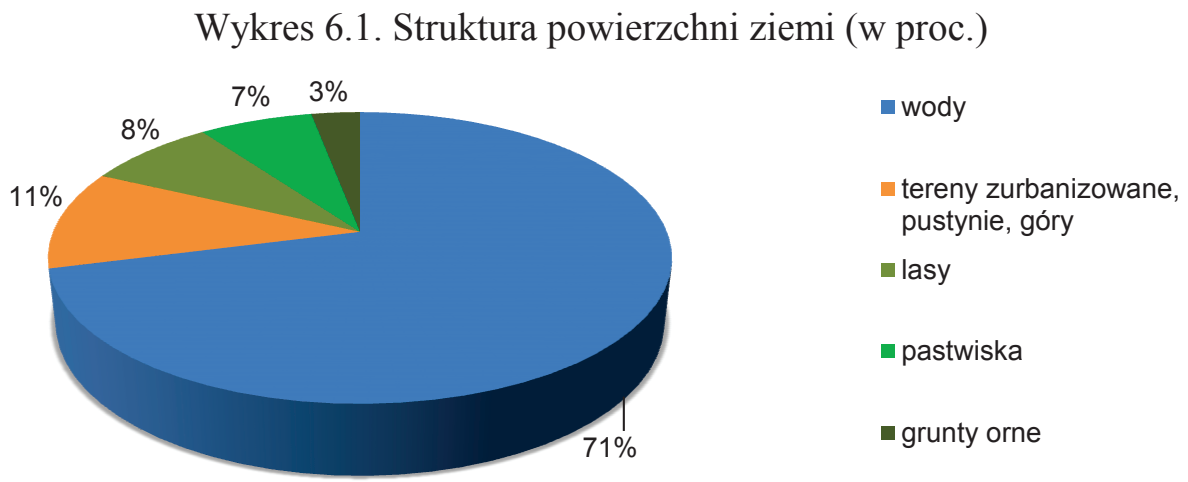

Źródto: Herausforderungen für die Landwirtschaft, Herausgeber Bayer AG, Communications and Public Affairs, Leverkusen 2015.

Istniejący 7\% udział w części ekstensywnie zagospodarowanych pastwisk daje w przyszłości pewne możliwości ich lepszego wykorzystania w celach produkcyjnych. Jednak, z uwagi na niekorzystny stan stosunków wodnych w różnych częściach świata, ograniczony jest wyraźny wzrost ich plonowania. Oznacza to, że wraz z rozwojem demograficznym kurczyć się będzie powierzchnia użytków rolnych przypadająca na osobę w skali świata. Prognozy demograficzne wskazują, że do 2050 roku liczba ludności na świecie może przekroczyć 9,5 mld osób.

$\mathrm{Z}$ danych zamieszczonych w tabeli 6.1 wynika, że skala zmian liczby ludności będzie zróżnicowana między poszczególnymi kontynentami. Najszybsza dynamika przyrostu demograficznego wystąpi w Afryce, która znacznie zwiększy swój udział w łącznej liczbie ludności świata w stosunku do stanu z 1950 roku.

\footnotetext{
${ }^{234}$ The World Bank Annual Report 2008, http://siteresources.worldbank.org/EXTANNREP2K8/ Resources/YR00_Year_in_Review_English.pdf.
} 
Tabela 6.1. Zmiany liczby ludności na różnych kontynentach w latach 1950-2050 (mln osób)

\begin{tabular}{|l|r|r|r|r|}
\hline \multirow{2}{*}{ Kontynent } & \multicolumn{2}{c|}{1950} & \multicolumn{2}{c|}{2050} \\
\cline { 2 - 5 } & mln osób & proc. & mln osób & proc. \\
\hline Europa & 549 & 21,7 & 716 & 7,3 \\
\hline Ameryka Północna & 173 & 6,8 & 435 & 4,4 \\
\hline Ameryka Lacińska i Karaiby & 169 & 6,7 & 780 & 8,0 \\
\hline Afryka & 229 & 9,0 & 2500 & 25,5 \\
\hline Azja & 1400 & 55,3 & 5300 & 54,2 \\
\hline Oceania & 13 & 0,5 & 57 & 0,6 \\
\hline Razem & $\mathbf{2 5 3 3}$ & $\mathbf{1 0 0 , 0}$ & $\mathbf{9 7 8 8}$ & $\mathbf{1 0 0 , 0}$ \\
\hline
\end{tabular}

Źródto: opracowanie na podstawie Herausforderungen für die Landwirtschaft..., op. cit.

Ludność Afryki w 1950 roku stanowiła 9\% ludności świata, a w 2050 roku udział ten może zwiększyć się do $26 \%$. Znaczący wzrost liczby ludności, w szczególności w liczbach bezwzględnych, oczekiwany jest również w Azji. Z kolei udział Europy w światowej populacji ludności wynoszący w 1950 roku $22 \%$, przy zachowaniu dotychczasowych trendów demograficznych, w 2050 roku obniży się do 7\%. Zarysowane tendencje zmian w demografii świata przyniosą wyraźny wzrost zróżnicowania zapotrzebowania na żywność na poszczególnych kontynentach.

Równocześnie ze wzrostem liczby ludności nastąpi zmniejszenie się powierzchni gruntów ornych przypadających na osobę. W 2050 roku, przy prognozowanym tempie przyrostu naturalnego, powierzchnia gruntów ornych na osobę może obniżyć się do około $1800 \mathrm{~m}^{2}$ (wykres 6.2).

Wykres 6.2. Powierzchnia gruntów ornych na osobę na świecie w latach $1950-2050\left(\mathrm{~m}^{2}\right)$

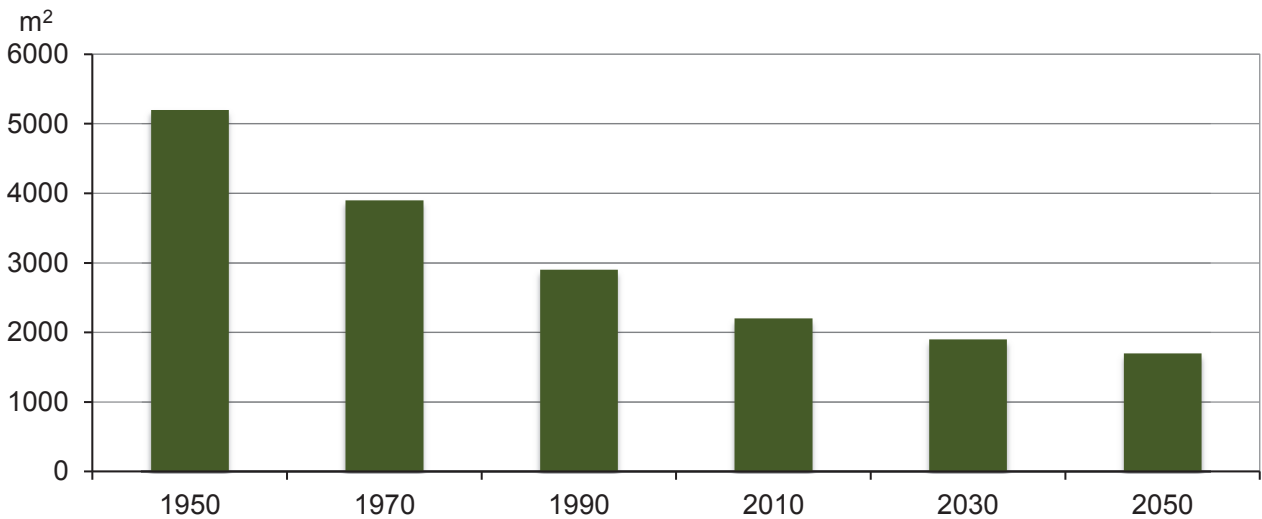

Źródto: opracowano na podstawie: Herausforderungen für die Landwirtschaft..., op. cit. 
Oceniając zasoby gruntów ornych, należy zwrócić uwagę na rosnące problemy wynikające z erozji oraz zasolenia gleb, które dotykają coraz to nowe powierzchnie gruntów.

Z długookresowych obserwacji wynika, iż tempo wzrostu produkcji rolniczej w czasie zmniejsza się. Według FAO średnioroczne tempo wzrostu plonów podstawowych roślin uprawnych na świecie w latach 1961-2007 wynosiło, w zależności od gatunku roślin, od 1,8 do $2,1 \%$ rocznie. $Z$ kolei prognoza dla okresu 2005/2007-2050 zakłada obniżenie się tempa wzrostu plonów dla tych gatunków roślin do $0,6-0,7 \%$ rocznie (tabela 6.2 ).

Tabela 6.2. Średnioroczny wzrost plonów wybranych roślin uprawnych na świecie (w proc.)

\begin{tabular}{|l|c|c|}
\hline \multicolumn{1}{|c|}{ Wyszczególnienie } & $1961-2007$ & $2005 / 2007-2050$ \\
\hline Pszenica & 2,1 & 0,7 \\
\hline Ryż & 1,8 & 0,6 \\
\hline Kukurydza & 2,0 & 0,6 \\
\hline
\end{tabular}

Źródto: The State of Food and Agriculture, Food and Agriculture Organization of the United Nations, Rome 2012; The Future of Food and Agriculture, Trends and Challenges, Food and Agriculture Organization of the United Nations, 2017.

Również w USA obserwuje się spadkowe tendencje w zakresie kształtowania się dynamiki plonowania roślin. $\mathrm{Z}$ danych zamieszczonych w tabeli 6.3 wynika, że średnioroczne wzrosty plonów na początku analizowanego okresu cechowały się wyższą dynamiką plonowania niż pod koniec okresu analizy. Tendencje te są wyraźniejsze w przypadku kukurydzy, bawełny, ryżu oraz pszenicy, natomiast mniej wyraźne w przypadku soi.

Tabela 6.3. Wskaźniki wzrostu plonów roślin uprawnych w USA w różnych okresach (w proc.)

\begin{tabular}{|c|c|c|c|c|c|c|}
\hline Rok & Kukurydza & Bawełna & Ryż & Jęczmień & Pszenica & Soja \\
\hline $1950-1960$ & 3,6 & 5,1 & 3,7 & 1,3 & 4,6 & 0,8 \\
\hline $1960-1970$ & 2,8 & $-0,2$ & 3,0 & 3,2 & 1,7 & 1,3 \\
\hline $1970-1980$ & 2,3 & $-0,9$ & $-0,5$ & 1,5 & 0,8 & $-0,1$ \\
\hline $1980-1990$ & 2,6 & 4,5 & 2,3 & 1,2 & 1,7 & 2,5 \\
\hline $1990-2000$ & 1,4 & $-0,1$ & 1,3 & 0,9 & 0,6 & 1,1 \\
\hline $2000-2010$ & 1,1 & 2,7 & 0,7 & 1,7 & 0,9 & 1,4 \\
\hline $1950-2010$ & 2,31 & 1,86 & 1,74 & 1,63 & 1,71 & 1,18 \\
\hline
\end{tabular}

Źródto: USDA, Economic Research Service using agricultural yield survey data form USDA, National Agricultural Statistics Service, 2013. 


\subsubsection{Zmiany klimatu - nowe wyzwanie dla rolnictwa}

Wśród przyczyn spadku plonów roślin wymienić należy: ujawnianie się działania prawa malejących efektów nakładów, niekorzystne zmiany klimatu, w tym zmiany temperatur i ilości oraz rozkładu opadów, a także występowanie okresowo anomalii pogodowych oraz rezygnację $\mathrm{w}$ niektórych krajach $\mathrm{z}$ uprawy roślin genetycznie modyfikowanych. W ocenie zmian produktywności wykorzystywany jest często wskaźnik TFP (Total Factor Productivity). Światowy rolniczy TFP w latach 2001-2013 wynosił średnio 1\% rocznie, jednak jego wzrost był nierównomierny w różnych okresach i regionach ${ }^{235}$. W przypadku krajów rozwijających się wartość wskaźnika TFP w latach 2001-2009 wynosiła średnio rocznie 1,9\%, w latach 1991-2000 była ona podobna, ale wyższa niż w latach 1981-1990. Wśród rozwijających się regionów w ostatnich latach roczny wzrost TFP był najszybszy w: Azji, Ameryce Środkowej, Afryce Północnej i Ameryce Południowej. Wzrost wydajności rolnictwa od dawna uważany jest za najważniejsze źródło wzrostu gospodarczego w sektorze rolnym. $\mathrm{Z}$ badań przeprowadzonych przez D. Jorgensona i S. Morrisa ${ }^{236}$ wynika, że spośród 44 sektorów objętych badaniami tylko 3 osiągnęły wyższe wskaźniki wzrostu produktywności niż rolnictwo. Daje się zauważyć jednak, że o ile w krajach rozwijających się obserwujemy rosnącą tendencję wskaźnika TFP, to w krajach wysoko rozwiniętych kierunek zmian jest odwrotny. Dość wysoki wzrost produktywności rolnictwa w ostatnich latach wynikał przede wszystkim z wdrażania innowacji i zmian technologicznych, w tym w szczególności z dokonującego się postępu biologicznego, ze szczególnym uwzględnieniem wykorzystania osiągnięć biotechnologii. Innowacje wymagają nakładów finansowych, które pochodzą zarówno ze źródeł publicznych, jak i prywatnych. $Z$ badań wynika, że publiczne inwestycje w badania na rzecz rolnictwa przyniosły duże korzyści ekonomiczne, przy stopach zwrotu na poziomie $20-60 \%$. Coraz częściej również firmy prywatne inwestują w działalność B+R. W skali globalnej wzrost produktywności stanowi rosnący udział w zwiększaniu produkcji rolnej, zmniejszając presję na angażowanie dodatkowych zasobów naturalnych dla zaspokojenia rosnącego zapotrzebowania na żywność i produkty rolne. Dzięki inwestowaniu w działalność B+R możliwe jest osiąganie wzrostu produktywności rolnictwa.

Wraz z rozwojem demograficznym oraz rozwojem gospodarczym i towarzyszącym mu wzrostem dochodów ludności należy oczekiwać wzrostu popytu

\footnotetext{
${ }^{235}$ K.O. Fuglie, N.E. Rada, Resources, Policies, and Agricultural Productivity in Sub-Saharan Africa, „Economic Research Report” 2013, nr 145, USDA, Economic Research Service, Washington, D.C.

${ }^{236}$ D. Jorgenson, S. Morris, The Economics of productivity, Edward Elgar Publishing Limited, Cheltenham 2009.
} 
na żywność, choć w różnym tempie w różnych grupach krajów. Kraje o wysokim dochodzie (np. w Europie Zachodniej) wykazują niskie reakcje popytowe na żywność i słabo reagują na zmiany dochodów. Z kolei kraje o średnim i niskim poziomie dochodów (np. Chiny i Indie) cechują się stosunkowo wysokim poziomem elastyczności popytu, co oznacza znacznie większy wpływ wzrastających dochodów na popyt na żywność. Biorąc pod uwagę większą elastyczność dochodów i wysokie tempo wzrostu gospodarczego w krajach o średnim i niskim dochodzie, a także spodziewane zmiany demograficzne, należy oczekiwać tu szybszego wzrostu popytu na żywność niż w krajach wysoko rozwiniętych. Nie ulega wątpliwości, że w nadchodzących dekadach popyt na żywność w skali światowej będzie wzrastać. Dodatkowo dochodzą do tego zmiany modelu konsumpcji.

\subsubsection{Zmiany modelu konsumpcji żywności}

Wraz ze wzrostem dochodów ludności nie tylko wzrasta popyt na żywność, ale również zmienia się struktura tego popytu w kierunku zwiększonego zapotrzebowania na bardziej wartościowe produkty, do których należą artykuły pochodzenia zwierzęcego. Zjawisko takie występuje w szczególności w krajach słabiej i średnio rozwiniętych. Jak wynika $z$ danych zamieszczonych $w$ tabeli 6.4, konsumpcja mięsa w perspektywie do 2050 roku w krajach wysoko rozwiniętych wzrośnie o około $20 \%$, podczas gdy w krajach rozwijających się oczekiwane jest podwojenie zapotrzebowania na mięso.

Tabela 6.4. Zmiany konsumpcji mięsa na świecie (w mln ton)

\begin{tabular}{|l|c|c|c|}
\hline \multicolumn{1}{|c|}{ Wyszczególnienie } & $2005-2007$ & 2050 & $\begin{array}{c}\text { Wskaźnik zmian } \\
\text { 2050/(2005-2007) }\end{array}$ \\
\hline Kraje wysoko rozwinięte & 109 & 130 & 1,2 \\
\hline Kraje rozwijające się & 147 & 316 & 2,1 \\
\hline Świat razem & 256 & 446 & 1,7 \\
\hline
\end{tabular}

Źródto: opracowanie na podstawie Herausforderungen für dier Landwirtschaft..., op. cit.

Udział wydatków na żywność w łącznych dochodach ludności jest w poszczególnych krajach mocno zróżnicowany i zależny od poziomu dochodów. Zgodnie z prawem Engla, wraz ze wzrostem dochodów ludności w krajach wyżej rozwiniętych udział wydatków na żywność w wydatkach ogółem się zmniejsza. Przykładowo w takim kraju jak USA wynosi on zaledwie około $6,4 \%$, w Niemczech 10,3\%, natomiast w Chinach 25,0\%, Kenii 46,7\%, a w Nigerii aż 56,4\% ${ }^{237}$.

${ }^{237}$ Herausforderungen für die Landwirtschaft, Herausgeber Bayer AG, Communications and Public Affairs, Leverkusen 2015. 
Tym samym, przy założeniu wzrostu cen żywności, konsumenci w krajach biedniejszych znacznie wyraźniej odczuwają skutki tego wzrostu niż w krajach wysoko rozwiniętych. Przykładowo wzrost cen koszyka produktów żywnościowych w USA o $20 \%$ spowoduje wzrost łącznych wydatków na żywność o $1,28 \%$, podczas gdy w Nigerii - zakładając dotychczasowy poziom spożycia - o 11,2\%. W USA nie musi to natomiast wyraźnie wpłynąć na zmniejszenie konsumpcji żywności, podczas gdy w Nigerii, przy konieczności pokrycia kosztów pozażywnościowych, taki wzrost cen musi spowodować spadek spożycia lub zmianę struktury spożycia żywności.

\section{Ograniczenie strat surowców i produktów żywnościowych jako sposób na poprawe bezpieczeństwa żywnościowego}

Oceniając przyszłe możliwości pokrycia popytu na żywność w skali świata, nie należy gubić z pola widzenia strat surowców i produktów żywnościowych, jakie występują $w$ różnych ogniwach łańcuchów dostaw. Jak wynika $\mathrm{z}$ danych zamieszczonych w tabeli 6.5, wielkość strat surowców i produktów żywnościowych jest znaczna.

Tabela 6.5. Straty surowców i produktów żywnościowych w różnych ogniwach łańcuchów dostaw na świecie (w proc.)

\begin{tabular}{|l|c|c|c|c|c|}
\hline \multirow{2}{*}{\multicolumn{1}{c|}{ Kontynent }} & \multicolumn{5}{|c|}{ Ogniwa w łańcuchu żywnościowym } \\
\cline { 2 - 6 } & produkcja & $\begin{array}{c}\text { magazyno- } \\
\text { wanie }\end{array}$ & przetwórstwo & handel & konsumpcja \\
\hline Afryka Subsaharyjska & 39 & 38 & 7 & 13 & 3 \\
\hline Ameryka Południowa & 34 & 38 & 4 & 15 & 9 \\
\hline Południowowschodnia Azja & 33 & 23 & 6 & 17 & 21 \\
\hline $\begin{array}{l}\text { Północna Afryka/Zachodnia } \\
\text { i Centralna Azja }\end{array}$ & 29 & 21 & 4 & 19 & 27 \\
\hline Azja (kraje wysoko rozwinięte) & 18 & 24 & 3 & 12 & 43 \\
\hline Europa & 23 & 12 & 5 & 9 & 51 \\
\hline Północna Ameryka/Oceania & 17 & 6 & 9 & 7 & 61 \\
\hline
\end{tabular}

Źródlo: WRI Annual Report 2013, http://www.wri.org/sites/default/files/WRI_2013_Annual_ Report_fulldraft_100314.pdf.

Straty powstają zarówno na etapie produkcji i magazynowania produktów oraz przetwórstwa, jak i w handlu oraz bezpośredniej konsumpcji żywności. Wielkość strat w poszczególnych ogniwach łańcucha żywnościowego jest kontynentalnie zróżnicowana. W Europie, Ameryce Północnej i Oceanii oraz w wysoko rozwiniętych krajach Azji największe straty powstają w bezpośredniej konsumpcji. Z kolei na kontynentach o niskim poziomie rozwoju gospodarczego 
najwyższe straty notowane są w produkcji i magazynowaniu. Szacuje się, że nawet $1 / 3$ produktów żywnościowych jest tracona na różnych etapach produkcji, przetwórstwa, handlu i konsumpcji, co odpowiada około 1,3 mld ton. Taka ilość wystarczyłaby na wyżywienie około 2 mld osób. Niezależnie od dokładności tego szacunku można przyjąć, że istnieje możliwość ograniczenia znacznej części strat w łańcuchu żywnościowym. Należy zauważyć, że w rozwiązywaniu problemów żywnościowych duże znaczenie ma wykorzystywanie postępu w rolnictwie i pozostałych ogniwach łańcucha żywnościowego.

\subsection{Postęp biologiczny - ujęcie teoretyczne}

\subsubsection{Istota postępu w gospodarce}

Wiedza jest podstawą do kreacji szeroko rozumianego postępu. Jest ona tworzona dzięki wielu różnym mechanizmom. Uczestniczą w nich uczelnie, ośrodki badawcze, rząd, przedsiębiorstwa. Z punktu widzenia ekonomii nie jest określone, w jaki sposób ustalane są kierunki badań w instytucjach niezwiązanych z rynkiem, a na pewno nie ma wyjaśnienia zasady oddziaływania cen i kosztów będących objaśnieniem korzyści z zastosowania innowacji w odniesieniu do przedsiębiorstw ${ }^{238}$. Dodatkowo przedsiębiorstwa korzystają z wiedzy tworzonej w ośrodkach naukowych, ale też działają w ramach posiadanej wiedzy naukowej i technicznej, odmiennej dla poszczególnych firm. Tworzenie nowej wiedzy może być finansowane ze środków na działalność B+R. Pewna jej część może pochodzić $\mathrm{z}$ badań finansowanych przez różne instytucje, np. w ramach programów rządowych, wsparcia przez fundacje czy z uczelni. Wiedza ogólnie dostępna jest możliwa do wykorzystania przez wszystkich przedsiębiorców, o ile uznają oni, że jest to opłacalne i o ile posiadają oni kwalifikacje niezbędne do jej zastosowania.

Wynikiem rozwoju wiedzy są innowacje. Definicja innowacji ewoluowała. Początkowo za innowację uznawano pierwsze zastosowanie danego rozwiązania (on first application), obecnie zaś, z punktu widzenia przedsiębiorstwa, za innowację uznaje się każde wprowadzenie nowości, o ile jest to produkt czy proces nowy w danej firmie. Ze względu na to, że wiele innowacji jest istotnie poprawianych i udoskonalanych, innowacje imitacyjne mogą mieć w efekcie większe znaczenie gospodarcze niż oryginalny wynalazek ${ }^{239}$.

\footnotetext{
${ }^{238}$ W. Nordhaus, Innowacje, wzrost i dobrobyt. Postęp techniczny w ujęciu teoretycznym, PWN, Warszawa 1976.

${ }^{239}$ S. Marciniak (red.), Makro- i mikroekonomia. Podstawowe problemy, Wydawnictwo Naukowe PWN, Warszawa 2005.
} 
Postęp jest nieodłącznym czynnikiem determinującym ogólny rozwój każdej działalności człowieka, w tym również działalności rolniczej. Przez postęp należy rozumieć ciąg procesów i zmian zmierzających ku stanowi coraz doskonalszemu, lepszemu i wydajniejszemu. Postęp w rolnictwie kojarzy się z osiągnięciem wyższego poziomu produkcyjnego, jakościowego, ilościowego, jak również uczynienia pracy ludzkiej lżejszą i wydajniejszą ${ }^{240}$. Jest on ważnym elementem zmian, prowadzącym do wzrostu efektywności gospodarowania i poprawy jakości produktów. Spośród wielu zdefiniowanych podziałów postępu można wymienić ${ }^{241}$ :

- postęp techniczny - proces doskonalenia techniki wytwarzania, polegający na wprowadzaniu do produkcji rolniczej ulepszonych i doskonalonych środków technicznych,

- $\quad$ postęp technologiczny - wprowadzenie nowych technologii produkcji,

- postęp organizacyjny - proces zmian w organizacji gospodarstwa i organizacji pracy prowadzący do bardziej efektywnego wykorzystania podstawowych czynników produkcji i w efekcie poprawy ekonomicznych wyników gospodarowania,

- $\quad$ postęp społeczno-ekonomiczny - zmiany w zakresie stosunków społecznych i ustroju społecznego,

- postęp biologiczny - udoskonalenie organizmów roślinnych i zwierzęcych pod kątem cech oczekiwanych przez gospodarującego i odbiorcę produktów, w tym wprowadzanie nowych odmian i gatunków roślin oraz zwierząt.

\subsubsection{Pojęcie postępu w rolnictwie}

Pojęcie postępu w rolnictwie nie jest jednoznacznie zdefiniowane. W różnych okresach i u różnych autorów pojawiały się odmienne zestawy rodzajów postępu. A. Woś ${ }^{242}$ przedstawiał wąskie i szerokie ujęcie postępu technicznego w rolnictwie. W ujęciu wąskim postęp obejmuje innowacje o charakterze mechanicznym, a w ujęciu szerokim ulepszenia zarówno mechaniczne, jak i biologiczne.

Można także przedstawić trzy płaszczyzny postępu technicznego w rolnictwie: techniczną, biologiczną i ekonomiczną ${ }^{243}$. Każda $z$ form postępu może wystąpić niezależnie od zmian w innych sferach, ale dla osiągnięcia oczekiwanych

\footnotetext{
${ }^{240}$ D. Mańkowski, Postęp biologiczny w hodowli, nasiennictwie i produkcji ziemniaka w Polsce. Część I. Przegląd ilościowych metod oceny postępu hodowlanego i odmianowego, Biuletyn Instytutu Hodowli i Aklimatyzacji Roślin, nr 251, Radzików 2009.

${ }^{241}$ H. Runowski, Postep biologiczny w rolnictwie, Wydawnictwo SGGW, Warszawa 1997.

${ }^{242}$ A. Woś, Rachunek ekonomiczny w rolnictwie, PWRiL, Warszawa 1966.

${ }^{243}$ M. Rojewski, T. Rychlik, S. Stańko, Czynniki kształtujące poziom produkcji i dochodów w rolnictwie, PWRiL, Warszawa 1987.
} 
skutków muszą one być zwykle wdrażane we wzajemnym powiązaniu i uwzględniać stan otoczenia wewnętrznego i zewnętrznego ulepszanych procesów ${ }^{244}$. Współcześnie konieczne jest uwzględnianie także płaszczyzny ekologicznej. Uważa się nawet, że zmiana techniczna niespełniająca kryteriów ekologicznych nie może być uznawana za postęp ${ }^{245}$.

W. Herer ${ }^{246}$ oraz E. Heady ${ }^{247}$ przedstawili postęp w rolnictwie jako składową dwóch elementów: postępu biologicznego (dotyczącego procesów naturalnych) oraz mechanicznego (związanego z wyższym uzbrojeniem pracy). Nie budzi wątpliwości, że wyodrębnienie postępu biologicznego jako elementu postępu technicznego w rolnictwie jest zasadne, gdyż żywe organizmy roślin i zwierząt biorą bezpośredni udział w produkcji rolniczej.

Dla lepszego zrozumienia procesów wprowadzania postępu w rolnictwie można zaproponować jego podział na rodzaje w zależności od nośników postępu:

1. Postęp biologiczny - związany z wprowadzaniem do produkcji wszelkiego rodzaju organizmów żywych w charakterze środków produkcji (roślin i zwierząt).

2. Postęp mechanizacyjny - związany z wprowadzaniem maszyn i urządzeń technicznych o nowych lub ulepszonych funkcjach.

3. Postęp chemizacyjny - związany z wprowadzaniem nowości będących wynikiem naturalnych lub sterowanych przez człowieka procesów chemicznych w charakterze środków produkcji; dotyczy głównie nawozów i środków ochrony roślin, a także farmaceutyków, dodatków paszowych itd.

4. Postęp technologiczny - związany z innowacjami o charakterze ulepszeń dotyczących procesu produkcji; może dotyczyć terminów stosowania nakładów, wielkości dawek, proporcji, wzajemnego dopasowania poszczególnych nakładów.

5. Postęp organizacyjny - związany ze zmianami w organizacji przedsiębiorstwa oraz organizacji pracy, np. przydziału zadań.

Trzy pierwsze z wymienionych kategorii postępu mają charakter ucieleśniony. Wdrożenie każdego z nich wymaga zakupu lub wytworzenia odpowiednich środków. Postęp technologiczny i organizacyjny, chociaż mogą wymagać zmian w aparacie wytwórczym przedsiębiorstwa, oparte są na wiedzy i doświadczeniu, mają więc charakter nieucieleśniony.

\footnotetext{
${ }^{244}$ H. Runowski, Postęp biologiczny..., op. cit.

${ }^{245}$ S. Marciniak, Innowacje i rozwój gospodarczy, Ośrodek Nauk Społecznych PW, Warszawa 1997.

${ }^{246}$ W. Herer, Procesy wzrostu w rolnictwie, PWE, Warszawa 1970.

${ }^{247}$ E. Heady, Ekonomika produkcji rolniczej, PWRiL, Warszawa 1967.
} 
Wprowadzanie postępu technicznego nie zawsze wiąże się ze wzrostem produkcji. W uzasadnionych ekonomicznie przypadkach może występować stały poziom produkcji, a nawet jej spadek. Zawsze jednak musi być to wprowadzenie techniki efektywnej, a więc prowadzącej do obniżki jednostkowych kosztów wytwarzania.

\section{Postęp a poziom produkcji w ujęciu teoretycznym}

Na wykresie 6.3 przedstawiono efekty wprowadzania postępu w odniesieniu do wielkości produkcji. Funkcja produkcji $\mathrm{f}_{1}$ reprezentuje starą, a $\mathrm{f}_{2}$ nową technikę. Przy danym poziomie nakładów, przy zastosowaniu nowej techniki można uzyskać wyższy poziom produkcji.

Wykres 6.3. Wpływ wprowadzania postępu na poziom produkcji przy stałych i zmienionych relacjach cenowych

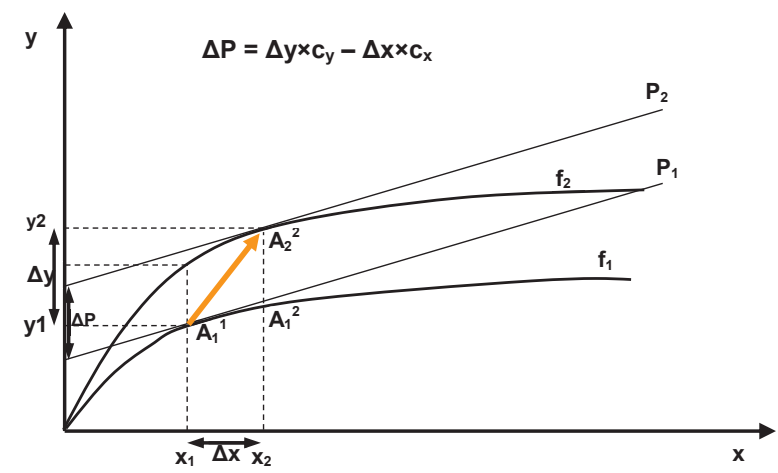

Źródło: opracowanie własne na podstawie L. Wicki, Efekty upowszechniania postepu biologicznego w produkcji roślinnej, Wydawnictwo SGGW, Warszawa 2010.

Poza wzrostem produkcji, przy danych nakładach, wprowadzanie nowej techniki może powodować także inne skutki. Przy stałych relacjach cenowych między nakładami zmienia się optymalny poziom nakładów. Przesunięcie linii reprezentującej relacje cenowe między nakładami z poziomu $\mathrm{P}_{1}$ do $\mathrm{P}_{2}$, reprezentujące oszczędność zasobów, powoduje, że optymalny poziom nakładów zmienia się $\mathrm{z} \mathrm{x}_{1}$ do $\mathrm{x}_{2}$. Punkt optymalnej produkcji przesuwa się $\mathrm{z}_{1}{ }^{1}$ do $\mathrm{A}_{1}{ }^{2} \mathrm{w}$ wyniku wprowadzenia nowej techniki, ale ze względów ekonomicznych najbardziej opłacalny jest poziom nakładów reprezentowany przez $\mathrm{A}_{2}{ }^{2}$. Dzięki wprowadzeniu postępu następuje nie tylko wzrost wydajności czynników wytwórczych, ale także zmienia się optymalny poziom i struktura nakładów (równowaga między kosztem granicznym i produktem granicznym znajdująca się $\mathrm{w}$ punkcie styku prostych $\mathrm{P}_{1}$ i $\mathrm{P}_{2} \mathrm{z}$ funkcjami $\mathrm{f}_{1}$ i $_{2}$ zostaje przesunięta $\mathrm{z}$ punktu $\mathrm{A}_{1}{ }^{1}$ do punktu $\mathrm{A}_{2}{ }^{2}$ ). Wzrost produkcji jest wypadkową tych zmian. 
W wyniku wprowadzenia postępu produkcja wzrasta o $\Delta \mathrm{y}$, a dodatkowy dochód dzięki wprowadzeniu postępu technicznego wynosi $\Delta \mathrm{P}$.

\section{Postęp a dochody rolników}

Nie zawsze wprowadzenie postępu prowadzi do zwiększenia dochodowości $\mathrm{w}$ rolnictwie. Po powszechnym wprowadzeniu danego rodzaju innowacji wszystkie przedsiębiorstwa mogą mieć niższą dochodowość niż przed jej wprowadzeniem. Wynika to z nieelastycznego popytu na wytwarzane produkty rolnictwa. Zwiększona produkcja często musi być sprzedawana po niższych cenach. Wprowadzenie postępu może być więc napędzane nie tyle chęcią zwiększenia dochodu, co chęcią uniknięcia jego redukcji. Ze względu na nieelastyczność popytu na produkty pochodzenia rolniczego wzrost produkcji prowadzi do spadku cen i większość korzyści przypada konsumentom. W wyniku tego procesu rolnicy są $\mathrm{w}$ pewnych przypadkach jedynie ogniwem pośredniczącym $\mathrm{w}$ przenoszeniu korzyści wynikających z postępu technicznego na konsumentów ${ }^{248}$. Tak więc postęp techniczny przyczynia się do zwiększania produkcji i obniżania jednostkowych kosztów wytwarzania, lecz nie zawsze pozwala to na zwiększanie dochodów w rolnictwie.

Wykres 6.4. Szacowana wielkość i podział rocznych korzyści wynikających z wprowadzania postępu biologicznego na świecie dla najważniejszych gatunków roślin

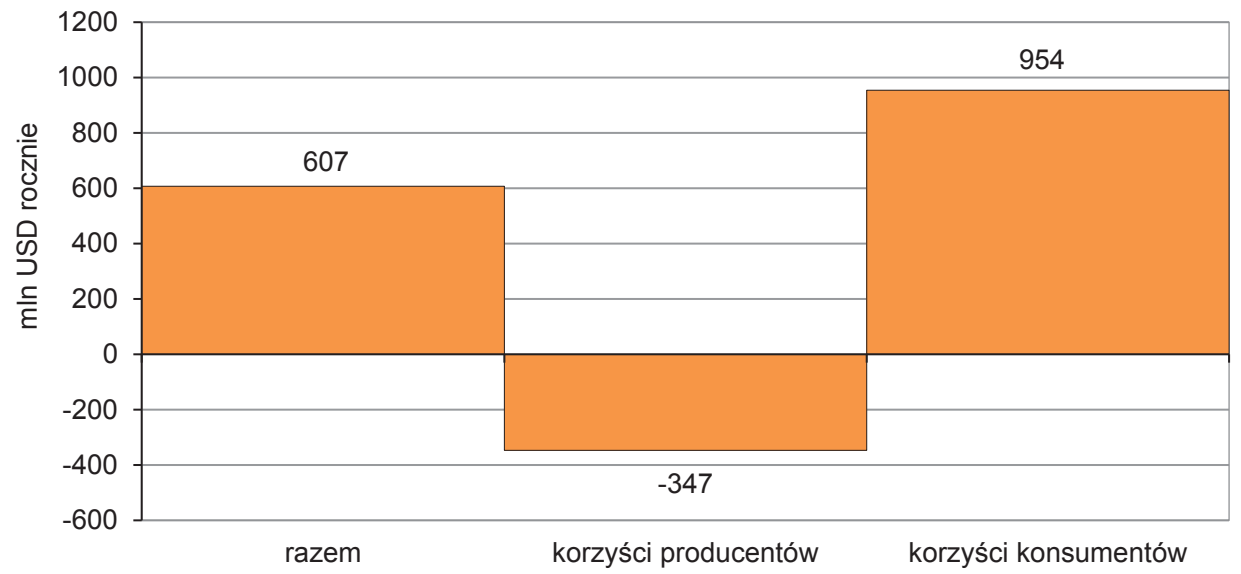

Źródlo: opracowanie własne na podstawie: K. Day-Rubenstein, P. Heisey, Crop Genetic Resources, [w:] K. Wiebe i N. Gollehon (red.), Agricultural Resources and Environmental Indicators, 2006 Edition, Economic Information Bulletin 16, USDA, Washington, D.C., July 2006, s. 52.

${ }^{248}$ W. Heijman i in., Ekonomika rolnictwa. Zarys teorii, Wydawnictwo Fundacja „Rozwój SGGW", Warszawa 1997. 
Wyniki przedstawione przez K. Day-Rubenstein i P. Heiseya ${ }^{249}$ dotyczące podziału korzyści z wprowadzania postępu biologicznego w zakresie najważniejszych gatunków roślin przedstawiono na wykresie 6.4.

Tabela 6.6. Klasyfikacja innowacji według E. Heady'ego i ich wpływ na poziom dochodów gospodarstw

\begin{tabular}{|l|l|l|}
\hline \multicolumn{1}{|c|}{$\begin{array}{c}\text { Kierunek } \\
\text { oddziaływania }\end{array}$} & \multicolumn{1}{|c|}{ Zwiększenie produkcji } & \multicolumn{1}{c|}{ Stała produkcja } \\
\hline $\begin{array}{l}\text { Zwiększenie } \\
\text { kosztów }\end{array}$ & $\begin{array}{l}\text { biologiczne (nowe odmiany, nowe rasy, lepsze sys- } \\
\text { temy żywienia, lepsze nawożenie i ochrona) - mogą } \\
\text { być stosowane przy elastycznym popycie } \\
\text { (w zakresie opłacalności) }\end{array}$ & nie dotyczy \\
\hline $\begin{array}{l}\text { Zmniejszenie } \\
\text { kosztów }\end{array}$ & $\begin{array}{l}\text { mieszane (nowa technika i substancje przyczynia- } \\
\text { jące się do wzrostu plonów przez pozytywne } \\
\text { oddziaływanie na glebę, rośliny, terminowość) - } \\
\text { mogą być stosowane przy elastycznym popycie } \\
\text { i w pewnym zakresie przy nieelastycznym popycie }\end{array}$ & $\begin{array}{l}\text { niebiologiczne (substy- } \\
\text { tucja pracy żywej kapi- } \\
\text { tałem) - mogą być } \\
\text { zawsze stosowane }\end{array}$ \\
\hline
\end{tabular}

Źródlo: opracowanie na podstawie L. Wicki, Efekty upowszechniania..., op. cit.

W tabeli 6.6 przedstawiono klasyfikację postępu ze względu na jego wpływ na koszty i dochody gospodarstw. Wprowadzanie zmian może prowadzić do wzrostu produkcji przy stałych lub malejących kosztach wytwarzania. Zawsze pozytywny wpływ na poziom dochodów wywierać będzie wprowadzanie innowacji oddziałujących nie na wielkość produkcji, a tylko na wysokość kosztów (zmiany dotyczące tylko mechanizacji, ale też postęp mechanizacyjny prowadzący do wyższych wydajności roślin i zwierząt).

\section{Dynamika wprowadzania postepu i jej bariery}

Nowości techniczne zwykle są drogie, co powoduje, że poszczególni producenci mogą stosować różne techniki i uzyskiwać podobny poziom kosztów. Jeżeli nośniki postępu tanieją ze względu na wzrost podaży, to producenci stosujący starszą niekonkurencyjną technikę są zmuszeni do zmiany, gdyż ich koszty wytwarzania są wyższe niż przeciętne w branży i nieadekwatne do nowego poziomu cen. Taka sytuacja może występować np. wtedy, gdy większość stosuje już genetycznie modyfikowane odmiany kukurydzy, co umożliwia im obniżenie kosztów produkcji i jednocześnie osiągnięcie wyższych plonów. Nawet w sytuacji niższych cen są w stanie zarabiać na produkcji, co przy tej samej cenie i starej

${ }^{249}$ K. Day-Rubenstein, P. Heisey, Crop Genetic Resources, [w:] K. Wiebe i N. Gollehon (red.), Agricultural Resources and Environmental Indicators, 2006 Edition, Economic Information Bulletin 16, USDA, Washington, D.C., July 2006, s. 50-58. 
technice nie byłoby możliwe. W rolnictwie dynamika wprowadzania opłacalnych innowacji jest wysoka, gdyż charakteryzuje się ona dużą konkurencyjnością. Dobrym przykładem jest szybka modernizacja produkcji mleka w Polsce, w tym prawie całkowite wyparcie ras bydła o niższej wydajności mlecznej.

Dynamika upowszechniania się określonego rodzaju innowacji ma zwykle charakterystyczny przebieg obrazowany krzywą introdukcji (wykres 6.5). Powolne w początkowym okresie tempo wprowadzania nowości wynika z braku akceptacji przez większość potencjalnych odbiorców, co wynika z dużego ryzyka wiążącego się z ich zastosowaniem, niedostateczną wiedzą na ich temat, a także częstym brakiem możliwości sprawdzenia nowości w praktyce.

Wykres 6.5. Klasyczny przebieg krzywej introdukcji nowych technik wytwarzania

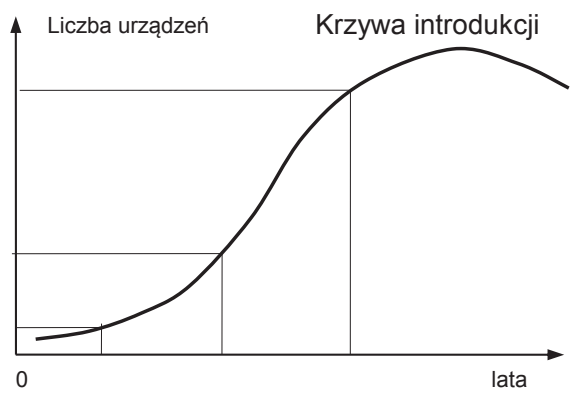

Źródto: opracowanie własne.

Dyfuzja innowacji (postępu) czasem przebiega wolno lub obserwuje się jej niskie upowszechnienie. Wynika to $\mathrm{z}$ istnienia barier o charakterze społecznym i ekonomicznym. Do pierwszej grupy należy zaliczyć takie czynniki, jak: brak wiedzy, nieukierunkowane wykształcenie, zmiana uciążliwości pracy, skrócenie czasu pracy, wzrost prestiżu, bezrobocie. Do barier o charakterze ekonomicznym należy zaliczyć przede wszystkim: brak środków na wprowadzanie innowacji (bariera finansowa), wynikający ze zbyt niskich dochodów producentów, brak pozytywnego oddziaływania danego rodzaju postępu na wyniki ekonomiczne gospodarowania (i na dochód), niski popyt i ceny produkcji. Inne czynniki to: zbyt mała skala produkcji, brak kredytów, wzrost ryzyka, niepodzielność nośnika postępu (np. maszyny), a także niski poziom wsparcia budżetowego ${ }^{250}$.

\footnotetext{
${ }^{250}$ Zestawienie ograniczeń opracowano na podstawie: A. Czyżewski, A. Poczta, Ł. Wawrzyniak, Interesy europejskiego rolnictwa $w$ świetle globalnych uwarunkowań polityki gospodarczej, „Ekonomista” 2006, nr 3, s. 347-369; Z. Kierul, E. Majewski, Postep techniczny w gospodar-
} 


\section{Kompleksowość postępu w rolnictwie}

Dzięki szeroko rozumianemu postępowi technicznemu z tej samej ilości nakładów materialnych uzyskuje się wyższy poziom produkcji (wykres 6.6).

Wykres 6.6. Kształtowanie się funkcji produkcji przy różnym poziomie zaawansowania postępu technicznego

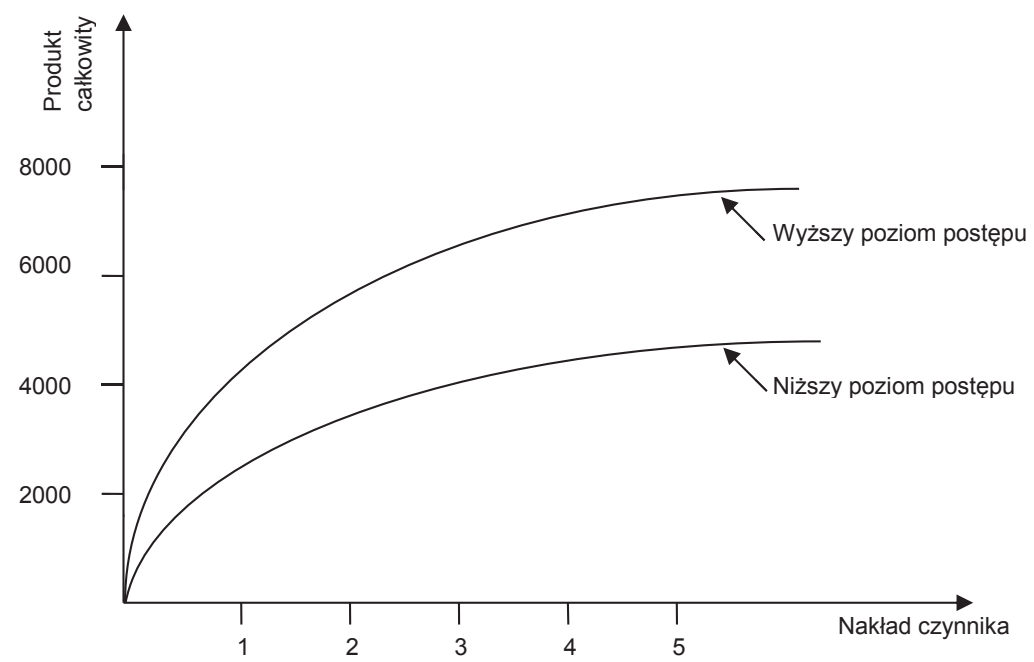

Źródło: opracowanie własne na podstawie: P. Samuelson, W. Nordhaus, Ekonomia, PWN, Warszawa 2008.

W ostatnim czasie szczególną rolę przypisuje się postępowi biologicznemu, który najogólniej ujmując, oznacza doskonalenie cech użytkowych roślin i zwierząt gospodarskich pod kątem jak najlepszego zaspokojenia oczekiwań producentów rolnych i konsumentów ${ }^{251}$. Postęp biologiczny jest swoistym substytutem nakładów rzeczowych i prowadzi do zmniejszenia kosztów produkcji rolniczej. Równocześnie, z uwagi na zmniejszenie nakładochłonności produkcji, sprzyja on ograniczeniu niekorzystnego oddziaływania produkcji rolniczej na środowisko naturalne. $\mathrm{Z}$ tego względu postęp biologiczny zaliczany jest ostatnio do najważ-

stwie rolniczym, PWRiL, Warszawa 1991; B. Klepacki, Technologia produkcji a gospodarstwo rolnicze (ujęcie teoretyczne), [w:] F. Maniecki (red.), Postęp techniczny a organizacja gospodarstw rolniczych, Wydawnictwo SGGW, Warszawa 1997, s. 34-50; F. Tomczak, Gospodarka rodzinna $w$ rolnictwie: uwarunkowania i mechanizmy rozwoju, IRWiR PAN, Warszawa 2005; A. Wicka (red.), Uwarunkowania ograniczania ryzyka w produkcji roślinnej z wykorzystaniem ubezpieczeń, Wydawnictwo SGGW, Warszawa 2013; J. Wilkin, Współczesna kwestia agrarna, PWN, Warszawa 1986; A. Woś, Prognoza przeksztatceń strukturalnych polskiego rolnictwa do 2020 roku, IERiGŻ, Warszawa 1996.

${ }^{251}$ H. Runowski, Postęp biologiczny..., op. cit. 
niejszych czynników rozwoju produkcji rolniczej. O ile bowiem jeszcze w latach 1950-1970 postęp biologiczny decydował o wzroście produkcyjności roślin w 18\%, to w latach 1971-1990 już w 52\% ${ }^{252}$. Oznacza to, że przedsiębiorstwa rolne powinny być zainteresowane wdrażaniem postępu biologicznego zarówno w produkcji roślinnej, jak i zwierzęcej. Warto jednak zaznaczyć, że szczególnie dobre efekty zapewnia łączne wdrażanie osiągnięć postępu biologicznego, technicznego i technologicznego oraz organizacyjnego. Trudno bowiem w pełni wykorzystać osiągnięcia postępu biologicznego $\mathrm{w}$ warunkach stosowania przestarzałej techniki czy technologii. Wysianie nawet najlepszych nasion za pomocą mało precyzyjnego siewnika na źle przygotowaną glebę nie zapewni wysokich plonów roślin. Podobnie żywienie krów o dużym potencjale genetycznym niezbilansowaną paszą nie zaowocuje ich wysoką wydajnością. Odnosząc się do znaczenia postępu biologicznego, nie można zapominać o potrzebie całościowego patrzenia na żywe organizmy, jakimi są rośliny czy zwierzęta. Jednostronne kształtowanie postępu, np. dążenie wyłącznie do maksymalizacji wydajności, z czasem ujawnia szereg niekorzystnych zjawisk, do których można zaliczyć pogorszenie zdrowotności organizmów i częstsze zachorowania oraz związaną z tym potrzebę stosowania dużych ilości środków weterynaryjnych czy chemicznych środków ochrony, co prowadzi do pogorszenia jakości produktów, powodując określony sprzeciw ze strony konsumentów. Kwestie te mogą być łagodzone przez kompleksowe podejście do kształtowania postępu biologicznego. Postęp biologiczny od zarania dziejów stanowił czynnik wzrostu produkcji rolnej, choć jego znaczenie było początkowo niewielkie w stosunku do innych form postępu, takich jak postęp mechanizacyjny, chemizacyjny czy technologiczny. $\mathrm{Z}$ czasem rola postępu biologicznego w rolnictwie wydatnie się zwiększyła.

\subsubsection{Postęp biologiczny i główne efekty jego wprowadzania}

Obecnie uważa się, że mimo wciąż bardzo dużego znaczenia innych kategorii postępu (mechanizacyjny, chemizacyjny, organizacyjny), znaczenie postępu biologicznego jest większe niż innych, gdyż efekt z jego zastosowania oddziałuje w okresie dłuższym niż jeden sezon (wykres 6.7). Nakłady nawozów, środków ochrony roślin, a nawet bardziej staranna pielęgnacja pozwalają jedynie na jednorazowy wzrost plonów (A). Ulepszenia odmian pozwalają na skokowy, trwały wzrost poziomu plonowania (B). Ciągły dopływ ulepszeń prowadzi do stałego, obserwowanego także w długim okresie, wzrostu produktywności $(\mathrm{C})^{253}$.

\footnotetext{
${ }^{252}$ E. Nalborczyk, Postęp biologiczny a rozwój rolnictwa w końcu XX i początkach XXI stulecia, Agricola 33 - suplement, Wydawnictwo SGGW, Warszawa 1997.

${ }^{253}$ K. Day-Rubenstein i in., Crop Genetic resources. An Economic Appraisal, Economic Information Bulletin 2, USDA, Washington, D.C. 2005.
} 
Wykres 6.7. Różne efekty wprowadzenia postępu do produkcji rolniczej

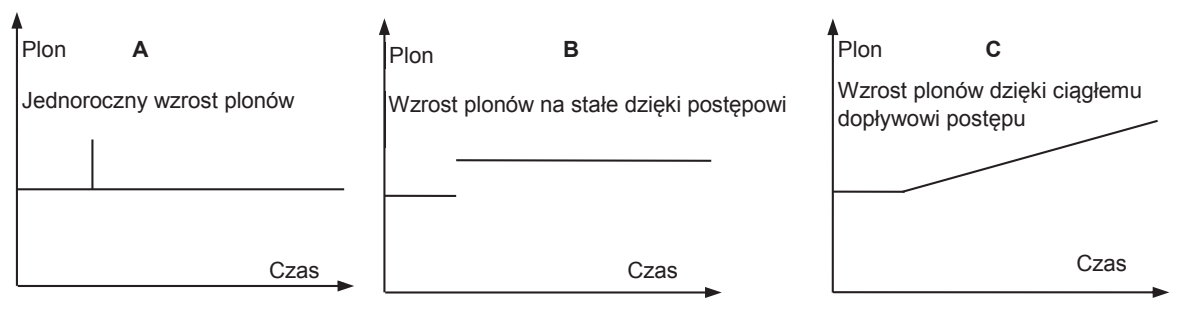

Źródto: opracowano na podstawie K. Day-Rubenstein i in., Crop Genetic resources. An Economic Appraisal, Economic Information Bulletin 2, USDA, Washington, D.C. 2005.

Przedstawiona powyżej zależność jest jednocześnie przyczyną niskiego popytu na nośniki postępu biologicznego, tj. kwalifikowane nasiona. Wynika to z możliwości samodzielnego uzyskiwania rozmnożenia materiału siewnego i korzystania z efektów postępu bez nabywania jego nośników. Współcześnie możliwość taka jest coraz bardziej ograniczana ze względu na oferowanie przez hodowców odmian hybrydowych i genetycznie modyfikowanych, których nie można rozmnażać we własnych gospodarstwach.

Wykres 6.8. Elementy luki plonowania w produkcji roślinnej

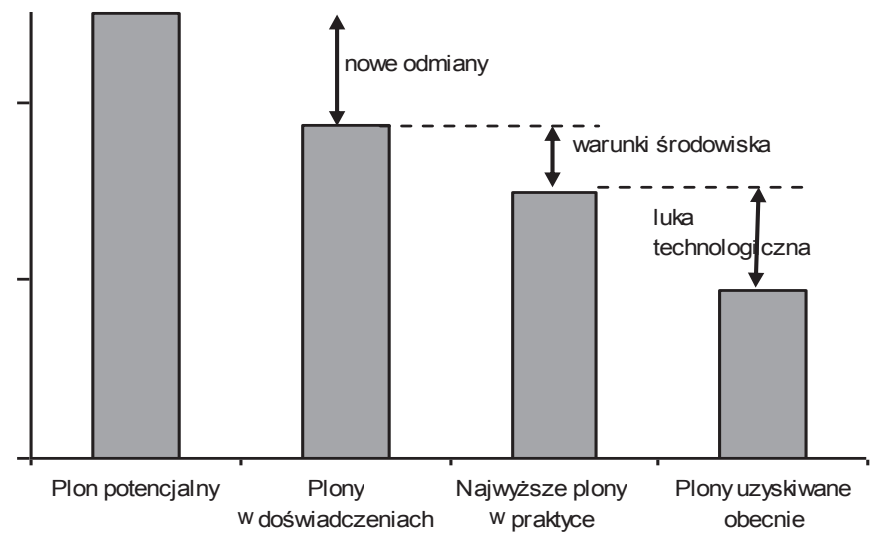

Źródto: opracowanie na podstawie D. Tran, N. Nguyen, Declining Productivity Gains and the Field Gap in Rice, [w:] M. Hall (red.), Farming Systems and Poverty, Improving farmers' livelihoods in a changing World, FAO and World Bank, Rome and Washington, D.C. 2001.

Należy jednak pamiętać, że wysoka produkcyjność procesów uzyskiwana może być jedynie w przypadku, gdy żaden z czynników nie limituje wydajności procesów produkcji. Badania wykonane dla polskiego rolnictwa wskazują, że potencjał produkcyjny odmian jest wykorzystany zaledwie w $50 \%$ zarówno 
ze względu na niskie zużycie nasion kwalifikowanych oraz nieodpowiednią technologię $^{254}$, jak i wysoki udział słabych gleb ${ }^{255}$. Luka wykorzystania potencjału odmian może być określona jako część różnicy między potencjalnym plonem, za który można uznać plon uzyskiwany w doświadczeniach, a plonem przeciętnie osiąganym w rolnictwie. Czynnikami wpływającymi na pojawianie się różnicy plonów są więc: luka technologiczna, warunki środowiska naturalnego i poziom upowszechniania postępu biologicznego (wykres 6.8).

\section{Postęp biologiczny jako źródlo wzrostu produktywności rolnictwa}

W literaturze można spotkać wiele definicji i nazw postępu biologicznego. Używa się niekiedy zamiennie takich pojęć, jak: postęp biologiczny, postęp hodowlany, postęp odmianowy czy postęp genetyczny ${ }^{256}$. Według J. Krzymuskiego ${ }^{257}$ postęp biologiczny $\mathrm{w}$ rolnictwie oznacza wzrost wartości użytkowej roślin uprawnych i zwierząt gospodarskich tworzony przez hodowlę roślin i zwierząt oraz wykorzystanie efektów tej hodowli w produkcji. Oznacza to wieloetapowy proces tworzenia i przekazywania do produkcji nowych odmian roślin oraz ras i typów użytkowych zwierząt. Zdaniem D. Stankiewicz ${ }^{258}$ postęp biologiczny wiąże się z doskonaleniem cech genetycznych organizmów żywych w kierunku podniesienia wydajności i jakości produkcji rolniczej. W odniesieniu do hodowli roślin przejawem postępu biologicznego są nowe metody prac hodowlanych, w tym różne sposoby modyfikowania genotypu roślin, jak również nowe odmiany i gatunki roślin. Takie ujęcie postępu biologicznego kojarzyć należy z postępem hodowlanym, czyli sumą różnych cech wartości gospodarczej i użytkowej wnoszonej przez odmiany do zarejestrowanych zestawów odmian poszczególnych roślin uprawnych. Według D. Mańkowskiego ${ }^{259}$ przez postęp biologiczny należy rozumieć całokształt zmian samoczynnych (naturalnych), bądź wynikających z celowej działalności człowieka (antropogeniczny), w organizmach roślinnych i zwierzęcych wpływających na cechy indywidualne tych orga-

\footnotetext{
${ }^{254}$ L. Wicki, H. Dudek, Wpływ podstawowych nakładów plonotwórczych na poziom i wartość produkcji w gospodarstwach rolniczych, ,Roczniki Nauk Rolniczych. Seria G” 2005, t. 92, nr 1, s. 30-41.

${ }^{255}$ S. Krasowicz, Możliwości zwiększenia produkcji zbóż w Polsce, [w:] Czy Polsce grozi kryzys zbożowy, Wydawnictwo Wieś Jutra, Warszawa 2007, s. 69-70.

${ }^{256}$ J. Krzymuski, Postęp biologiczny w rolnictwie, [w:] A. Woś (red.), Encyklopedia Agrobiznesu, Fundacja Innowacja, Warszawa 1998; H. Runowski, Postęp biologiczny..., op. cit.; D. Mańkowski, Postęp biologiczny w hodowli..., op. cit.

${ }^{257}$ J. Krzymuski, Postęp biologiczny $w$ rolnictwie, op. cit.

${ }^{258}$ D. Stankiewicz, Rola postępu biologicznego w rolniczej produkcji roślinnej, Informacja nr 672, Sejm RP, Warszawa 1999.

${ }^{259}$ D. Mańkowski, Postęp biologiczny w hodowli..., op. cit.
} 
nizmów. W sensie rolniczym jest to całokształt zmian wpływających na wartość technologiczno-użytkową roślin i zwierząt gospodarskich. Postęp biologiczny w rolnictwie ma na celu podniesienie wydajności i/lub poprawienie jakości produkcji rolniczej. Według M. Świtońskiego i S. Malepszego ${ }^{260}$ postęp biologiczny w rolnictwie jest definiowany jako tworzenie nowych genotypów roślin i zwierząt warunkujących powstanie cech lepiej odpowiadających współczesnej praktyce rolniczej. Cechy te związane są z produkcyjnością oraz zdrowotnością roślin i zwierząt, przydatnością wytwarzanych surowców do przetwórstwa, a także oczekiwaniami konsumentów. Postęp ten coraz bardziej zależy od aplikacji osiągnięć genomiki i inżynierii genetycznej. Hodowle roślin i zwierząt korzystają z szerokiej palety technik badawczych genetyki molekularnej, głównie w dwóch obszarach. Pierwszym jest podejmowanie decyzji sekwencyjnych opartych na analizie sekwencji nukleotydów DNA, a drugim poszerzanie zmienności genetycznej w populacjach hodowlanych na drodze modyfikacji genetycznych, polegających przede wszystkich na tworzeniu organizmów (głównie roślin) z obcymi gatunkowo genami. Stwarza to nie tylko atrakcyjne perspektywy uzyskiwania postępu biologicznego, ale również nowe możliwości w zakresie wykorzystania roślin uprawnych i zwierząt hodowlanych. Ostatnie trzydziestolecie przyniosło spektakularne dokonania w obu tych obszarach. Pierwsze zmodyfikowane genetycznie rośliny uprawne oraz transgeniczne zwierzęta domowe uzyskano w pierwszej połowie lat 80 . XX wieku ${ }^{261}$. Rozwój metod hodowli w ujęciu historycznym przedstawiono na rysunku 6.1 oraz w tabeli 6.7.

O ile tradycyjne metody hodowli oparte początkowo na selekcji, a następnie krzyżowaniu roślin nie wywoływały sprzeciwu społecznego, o tyle najnowsze metody hodowlane $\mathrm{w}$ ramach biotechnologii, w tym szczególnie oparte na metodach inżynierii genetycznej i genomice, są przedmiotem zagorzałych dyskusji na temat ich wpływu na zdrowie ludności. Podstawowym działaniem hodowlanym jest selekcja, czyli wybór osobników rodzicielskich następnego pokolenia, a podjęcie decyzji selekcyjnej jest poprzedzone oceną wartości genotypowej organizmów, spośród których ma nastąpić wybór. Ocena taka, do niedawna prowadzona $\mathrm{w}$ oparciu o fenotyp, coraz częściej opiera się na analizie wytypowanych genów lub jest wręcz globalną oceną całego genomu (tzw. selekcja genomowa). Wprowadzenie do selekcji analiz molekularnych markerów genetycznych umożliwiło opracowanie metodologii selekcji opartej na markerach genetycznych $^{262}$. Intensywne badania z zakresu genomiki, a konkretnie budowa-

\footnotetext{
${ }^{260}$ M. Świtoński, S. Malepszy, Postęp biologiczny w rolnictwie w erze genomiki i modyfikacji genetycznych, „Nauka” 2012, nr 1, s. 25-35.

${ }^{261}$ Ibid.

262 Ibid.
} 
nie markerowych map genomu podjęto na początku lat 90. XX wieku. Przełomem w genomice było zakończenie pierwszego etapu sekwencjonowania genomu człowieka i ogłoszenie w lutym 2001 roku dwóch publikacji zamieszczonych w „Nature” i „Science” opisujących jego organizację. Osiągnięcie to otworzyło szerokie możliwości poznania sekwencji genomowych roślin uprawnych i zwierząt hodowlanych.

Rysunek 6.1. Metody i technologie stosowane w hodowli roślin

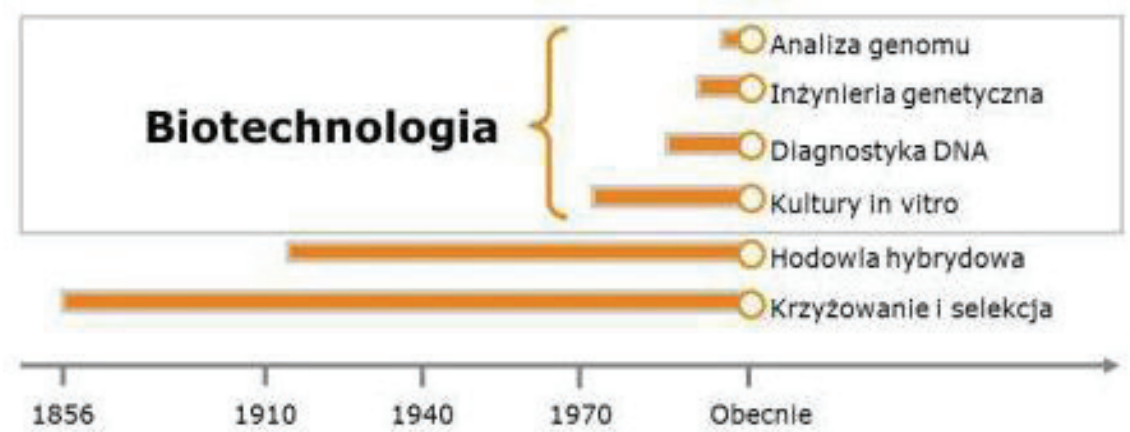

Źródto: https://www.kws.pl/aw/Burak-cukrowy/Hodowla/Metody-hodowli/ erbh/.

Tabela 6.7. Ewolucja metod hodowli roślin

\begin{tabular}{|c|l|}
\hline Rok & \multicolumn{1}{|c|}{ Metody hodowli roślin } \\
\hline od 10 000 lat p.n.e. & Dobór na zasadzie selekcji roślin \\
\hline 1866 & Dobór według zasad Mendla \\
\hline 1900 & Wprowadzenie krzyżowania roślin \\
\hline 1920 & Hodowla hybrydowa \\
\hline 1930 & Hodowla mutacyjna \\
\hline 1960 & Hodowla tkankowa \\
\hline 1996 & Sekwencjonowanie genomu \\
\hline 2000 & Wykorzystanie markerów w hodowli (genomika) \\
\hline
\end{tabular}

Źródto: Herausforderungen für die Landwirtschaft..., op. cit.

Skala wykorzystania modyfikowanych genetycznie roślin systematycznie się zwiększa, poczynając od 1966 roku. Wśród różnych modyfikacji genetycznych najczęściej wykorzystywana w praktyce jest tolerancja roślin na działanie herbicydu zwalczającego jedno- i dwuliścienne chwasty oraz nabycie przez rośliny właściwości uniemożliwiających żerowanie na nich larw szkodników. Omówione zmiany genetyczne organizmów zalicza się do tzw. pierwszej generacji modyfikacji genetycznej. Ostatnio coraz więcej miejsca poświęca się modyfikacjom genetycznym w ramach tzw. drugiej generacji. Prace te polegają na 
uzyskiwaniu roślin modyfikowanych genetycznie, które cechują się np. zwiększoną zawartością witamin czy kwasów omega 3, pozwalających obniżyć poziom cholesterolu. Obecnie zatem występują rośliny genetycznie modyfikowane różniące się między sobą zakresem modyfikacji genowej. Jedne są wynikiem przenoszenia genów z rośliny tego samego gatunku, ale innej odmiany, inne $\mathrm{z}$ kolei polegają na przenoszeniu genów z innego gatunku lub rodzaju rośliny. $\mathrm{Z}$ uwagi na coraz dalej idący zakres manipulacji genowych pojawiają się różne obszary sporu na temat jakości i bezpieczeństwa spożywania produktów żywnościowych wyprodukowanych z surowców uzyskanych z roślin modyfikowanych genetycznie. O ile producenci rolni z USA dość powszechnie wprowadzają do uprawy nasiona roślin modyfikowanych genetycznie, o tyle w Europie proces ten przebiega wolniej, a ostatnio możliwość stosowania tego typu nasion została prawnie zakazana.

\subsection{Postęp biologiczny $w$ produkcji roślinnej}

\subsubsection{Wykorzystanie roślin genetycznie modyfikowanych w produkcji rolniczej}

\section{Cechy uzyskiwane w roślinach genetycznie modyfikowanych}

Do najważniejszych czynników sprzyjających upowszechnianiu produkcji roślin genetycznie modyfikowanych należy uproszczenie produkcji i uzyskanie wyższej odporności na pewne czynniki biotyczne i abiotyczne, które negatywnie wpływają na rośliny i prowadzą do obniżki plonów, mimo stosowania odpowiednich nakładów produkcyjnych i przestrzegania reżimu technologicznego. Rolnicy wskazywali ponadto na inne przyczyny, które brali pod uwagę, podejmując decyzje o uprawie roślin GMO. Było to także zmniejszenie ilości zużywanych pestycydów oraz uproszczenie technologii produkcji.

Wynika z tego, że korzyści są postrzegane przede wszystkim z perspektywy ekonomicznej. Zarówno wzrost plonów, jak i obniżenie kosztów zabiegów i zużycia środków produkcji prowadzą do uzyskiwania wyższego dochodu z produkcji. Szacuje się, że większość, bo 45-95\% korzyści ekonomicznych z produkcji roślin modyfikowanych genetycznie przypada rolnikom, a hodowcy przejmują od 7 do $37 \%$ tej wartości (w zależności od gatunku) ${ }^{263}$. Różnica w poziomie uzyskiwanych plonów, w stosunku do odmian tradycyjnych, wynosi nawet $25-35 \%{ }^{264}$.

\footnotetext{
${ }^{263}$ E.J. Trigo, Veinte Años de Cultivos Genéticamente Modificados en la Agricultura Argentina 2016, http://argenbio.org/index.php?action=novedades\&note=747.

${ }^{264}$ Global Status of Commercialized Biotech/GM Crops: 2016, ISAAA Brief 52, Ithaca, NY 2016.
} 
Przeciętnie korzyści dla rolników wynikające z uprawy roślin GMO w 15\% wynikają z obniżenia kosztów nakładów, a w $85 \%$ z wyższego poziomu plonów ${ }^{265}$. W krajach, w których nie można wykorzystywać do produkcji odmian genetycznie modyfikowanych, w tym w Polsce, nie jest możliwe pełne konkurowanie na równych zasadach z producentami używającymi odmian GMO.

\section{Struktura wedlug gatunków}

Znaczenie roślin genetycznie modyfikowanych nie jest jednakowe dla wszystkich gatunków. Znaczny postęp uzyskano już w hodowli kukurydzy, soi czy bawełny, lecz dla wielu innych gatunków nie ma w tym zakresie komercyjnych osiągnięć. Na wykresie 6.9 przedstawiono udział poszczególnych gatunków w ogólnej powierzchni uprawy roślin modyfikowanych genetycznie na świecie w 2016 roku. Aż 98,8\% zajmują cztery gatunki: soja, kukurydza, bawełna oraz rzepak. Oprócz kukurydzy i rzepaku, rośliny te nie są uprawiane w Polsce, a więc presja konkurencyjna wynikająca z produkcji odmian GMO na polskie rolnictwo nie będzie zbyt duża.

Wykres 6.9. Udział najważniejszych gatunków roślin w ogólnej powierzchni uprawy GMO na świecie w 2016 roku

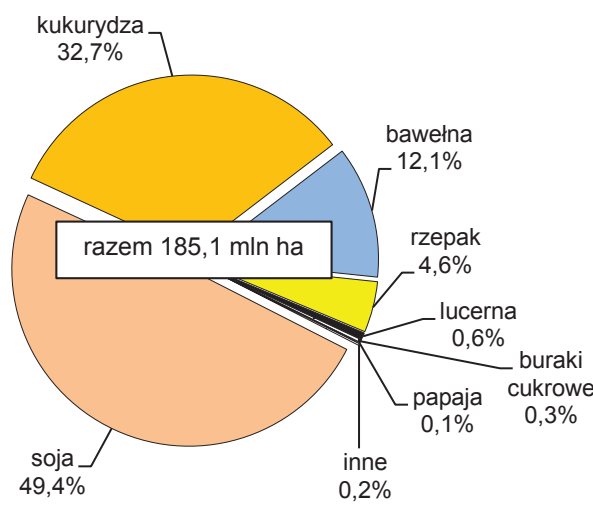

Wykres 6.10. Powierzchnia uprawy najważniejszych gatunków GMO na świecie w 2016 roku (w mln ha) i ich udział w uprawach ogółem (w proc.)

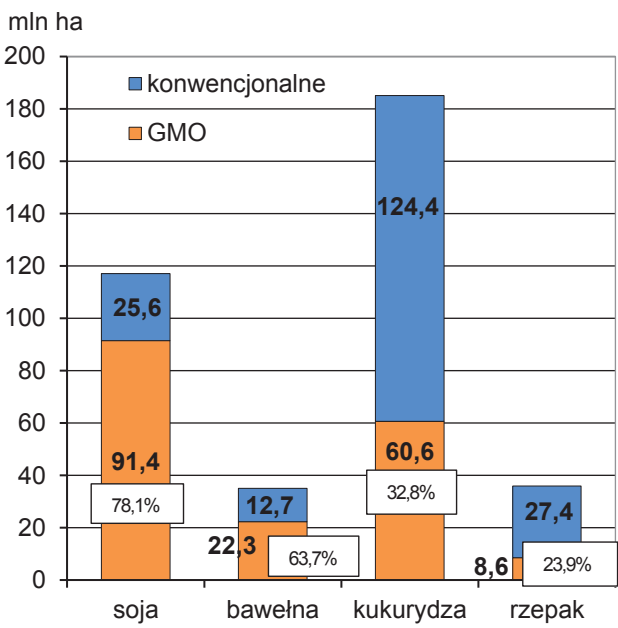

Źródto: opracowanie wtasne na podstawie: Global Status of Commercialized Biotech/GM Crops: 2016, ISAAA Brief 52, Ithaca, NY 2016.

${ }^{265}$ G. Brookes, P. Barfoot, GM crops: global socio-economic and environmental impacts 1996-2015, PG Economics Ltd, Dorchester, UK 2017. 
Biorąc pod uwagę przedstawione wcześniej cztery gatunki roślin, najwyższy udział mają rośliny GMO w powierzchni uprawy kolejno soi, bawełny i kukurydzy (wykres 6.10).

W produkcji soi i bawełny dominują rośliny modyfikowane genetycznie, a w produkcji kukurydzy mają one znaczny udział. W dokonanych modyfikacjach genetycznych największe znaczenie $\mathrm{w}$ produkcji mają rośliny $\mathrm{z}$ tolerancją na herbicydy - 47\% powierzchni produkcji i ze złożonymi odpornościami (np. na herbicydy i szkodniki) - 40\%. Rośliny z odpornością na owady zajmują $12 \%$ powierzchni uprawy GMO.

\section{Powierzchnia produkcji}

Zgodnie z dostępnymi danymi powierzchnia uprawy roślin GMO na świecie w 2016 roku wynosiła $185 \mathrm{mln}$ ha. W 1996 roku było to zaledwie $1,7 \mathrm{mln}$ ha (wykres 6.11). W latach 2000-2016 średnioroczny wzrost powierzchni uprawy tych roślin wynosił $9,1 \%$, ale po 2012 roku widoczne jest spowolnienie tego wzrostu, co oznacza, że następuje pewne nasycenie rynku. Producenci zainteresowani wprowadzaniem GMO do uprawy, o ile jest to dopuszczalne, w większości już podjęli taką produkcję. Dalsza ekspansja wymagałaby, aby powstały rośliny genetycznie modyfikowane innych gatunków. Wprowadzanie ulepszeń, np. w obrębie hodowli kukurydzy genetycznie modyfikowanej poprzez dodanie nowej cechy, nie będzie prowadziło do dalszego zwiększania znaczenia produkcji GMO na świecie. Roczna wartość sprzedaży nasion roślin modyfikowanych genetycznie wynosiła w 2016 roku 15,8 mld USD.

Wykres 6.11. Powierzchnia uprawy roślin genetycznie modyfikowanych na świecie

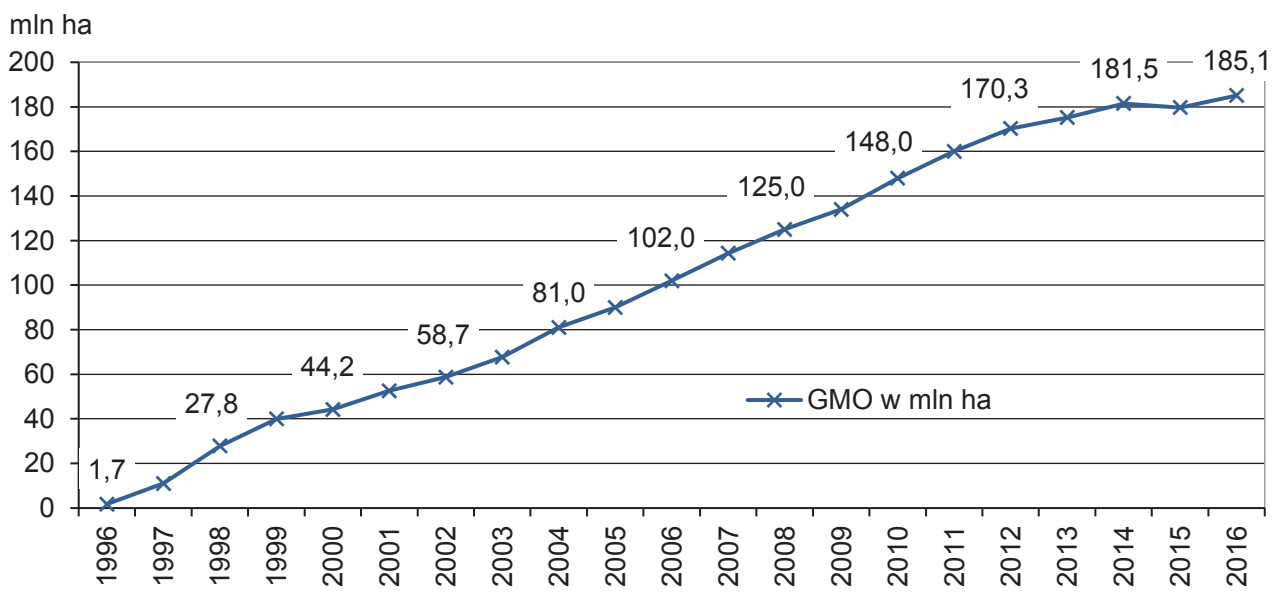

Źródto: Global Status of Commercialized Biotech/GM Crops: 2016, op. cit. 


\section{Struktura produkcji GMO wedlug krajów}

Znaczenie roślin modyfikowanych genetycznie w powierzchni uprawy jest różne w poszczególnych krajach, w których prowadzona jest uprawa roślin GMO (wykres 6.12). W krajach Ameryki Południowej oraz w USA uprawiane są duże areały soi GMO. Kukurydza GMO jest uprawiana głównie w USA, podobnie bawełna GMO, której produkcja jest ponadto rozwinięta w niektórych krajach Azji (m.in. Indie i Pakistan).

Wykres 6.12. Powierzchnia uprawy roślin GMO w głównych krajach, w których prowadzona jest uprawa roślin GMO w 2016 roku (w mln ha) mln ha

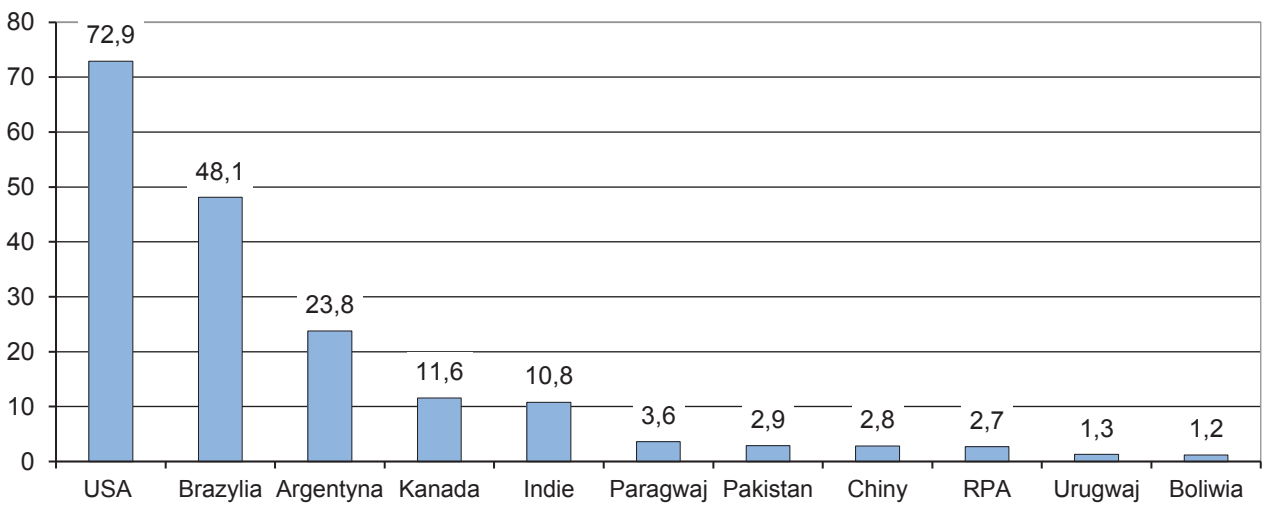

Źródto: opracowanie własne na podstawie: Global Status of Commercialized Biotech/GM Crops: 2016, op. cit.

\section{Dynamika upowszechniania uprawy roślin GMO w USA}

W tabeli 6.8 przedstawiono zmiany powierzchni upraw wybranych roślin genetycznie modyfikowanych w USA. Można zauważyć, że dynamika wzrostu powierzchni przebiegała zgodnie z klasyczną krzywą introdukcji innowacji (patrz wykres 6.5). Rozwój uprawy roślin GMO przebiegał stopniowo. Początkowo, w pierwszej fazie ich upowszechniania, dynamika była stosunkowo niska. Niemniej w okresie 10-15 lat od pojawienia się określonej nowości na rynku zajmowała ona w zasadzie cały rynek.

Pierwsze uprawy roślin modyfikowanych genetycznie miały miejsce w 1996 roku. Od tego czasu następuje dynamiczny rozwój upraw roślin modyfikowanych w zakresie takich roślin, jak kukurydza, soja i bawełna. Dużą dynamiką cechuje się również przyrost uprawy genetycznie modyfikowanego rzepaku i buraków cukrowych. Znacznie wolniej wykorzystuje się modyfikacje genowe w uprawach warzyw. 
Tabela 6.8. Rozwój uprawy roślin genetycznie modyfikowanych w USA

\begin{tabular}{|c|c|c|c|c|c|c|}
\hline \multirow{2}{*}{ Rok } & \multicolumn{2}{|c|}{ Kukurydza } & \multicolumn{2}{c|}{ Soja } & \multicolumn{2}{c|}{ Bawełna } \\
\cline { 2 - 7 } & mln akrów & proc. areału & mln akrów & proc. areału & mln akrów & proc. areału \\
\hline 2000 & 19,89 & 25 & 40,10 & 54 & 9,47 & 61 \\
\hline 2001 & 19,68 & 26 & 50,37 & 68 & 10,88 & 69 \\
\hline 2002 & 26,82 & 34 & 55,47 & 75 & 9,91 & 71 \\
\hline 2003 & 31,44 & 40 & 59,46 & 81 & 9,84 & 73 \\
\hline 2004 & 38,04 & 47 & 63,93 & 85 & 10,38 & 76 \\
\hline 2005 & 42,53 & 52 & 62,67 & 87 & 11,25 & 79 \\
\hline 2006 & 47,78 & 61 & 67,21 & 89 & 12,68 & 83 \\
\hline 2007 & 68,27 & 73 & 58,91 & 91 & 9,42 & 87 \\
\hline 2008 & 68,79 & 80 & 69,66 & 92 & 8,15 & 86 \\
\hline 2009 & 73,42 & 85 & 70,48 & 91 & 8,05 & 88 \\
\hline 2010 & 75,85 & 86 & 71,99 & 93 & 10,21 & 93 \\
\hline 2011 & 81,21 & 88 & 70,46 & 94 & 13,25 & 90 \\
\hline 2012 & 85,50 & 88 & 71,79 & 93 & 11,58 & 94 \\
\hline 2013 & 87,64 & 90 & 72,29 & 93 & 9,23 & 90 \\
\hline
\end{tabular}

Źródło: opracowanie na podstawie J. Fernandez-Cornejo i in., Genetically Engineered Crops in the United States, „Economic Research Report” 2014, nr 162, USDA, Economic Research Service, Washington, D.C.

\section{Rośliny genetycznie modyfikowane - obszary sporu}

Nowoczesne metody osiągania postępu biologicznego związane z biotechnologią, a w szczególności z genomiką, są różnie oceniane zarówno przez producentów, jak i konsumentów. Część producentów rolnych docenia pozytywne efekty wprowadzania organizmów transgenicznych do produkcji rolnej, z kolei producenci hołdujący zasadom ekologii są im przeciwni. Pierwsza grupa producentów dostrzega wiele korzyści osiąganych z uprawy roślin modyfikowanych genetycznie (tabela 6.9).

Tabela 6.9. Przyczyny wprowadzenia odmian GMO do uprawy w USA (proc. wskazań farmerów)

\begin{tabular}{|l|c|c|c|c|}
\hline \multirow{2}{*}{$\begin{array}{c}\text { Przyczyna wprowadzenia } \\
\text { uprawy roślin GMO }\end{array}$} & \multicolumn{4}{c|}{ Rośliny modyfikowane genetycznie } \\
\cline { 2 - 5 } & soja HT & kukurydza HT & kukurydza Bt & bawełna HT \\
\hline Wzrost plonów & 60 & 71 & 77 & 77 \\
\hline Zmniejszenie zużycia pestycydów & 20 & 7 & 6 & 6 \\
\hline Uproszczenie technologii produkcji & 15 & 13 & 10 & 12 \\
\hline Inne & 5 & 9 & 7 & 5 \\
\hline
\end{tabular}

Uwaga: HT - herbicide tolerant (odporność na herbicydy), Bt - Bacillus thuringiensis (działanie owadobójcze)

Źródto: opracowanie na podstawie J. Fernandez-Cornejo i in., Genetically Engineered Crops..., op. cit. 
W przypadku uprawy soi wskazują oni przede wszystkim na możliwości osiągania wzrostu plonów oraz zmniejszenie kosztów zużycia pestycydów ${ }^{266}$. Producenci kukurydzy i bawełny do efektów tych zaliczają głównie wzrost plonowania roślin, a także oszczędności nakładów na uprawę i łatwiejsze zarządzanie procesem produkcyjnym. Rolnicy gospodarujący metodami ekologicznymi akceptują zakaz stosowania roślin modyfikowanych genetycznie.

Tabela 6.10. Wyniki badań dotyczących skłonności konsumentów do zapłaty premii za produkty wolne od GMO oraz produkty pochodzące ze wzbogaconych na drodze modyfikacji genowych roślin

\begin{tabular}{|c|c|c|c|}
\hline Autor & Kraj & Produkt & Gotowość do zapłaty premii \\
\hline $\begin{array}{l}\text { Huffman, } \\
2010\end{array}$ & USA & produkt & $\begin{array}{l}\text { Konsumenci płacą od } 19 \text { do } 26 \% \text { premii za produkt } \\
\text { z wewnątrzgennym dodatkiem witamin }\end{array}$ \\
\hline $\begin{array}{l}\text { Lusk, } \\
2003\end{array}$ & USA & złoty ryż & $\begin{array}{l}\text { Klienci gotowi są zapłacić } 0,93 \text { USD za ryż genetycznie } \\
\text { modyfikowany z dodatkiem witaminy A }\end{array}$ \\
\hline $\begin{array}{l}\text { Hartl } \\
\text { i Herrmann, } \\
2009\end{array}$ & Niemcy & rzepak & $\begin{array}{l}\text { W ankiecie internetowej stwierdzono, że konsumenci } \\
\text { gotowi byli zapłacić } 1,37 \text { euro za pół litra oleju z rzepaku } \\
\text { genetycznie modyfikowanego uzupełnionego kwasami } \\
\text { omega } 3 \text { i } 0,80 \text { euro za pół litra oleju genetycznie modyfi- } \\
\text { kowanego zawierającego związki redukujące cholesterol }\end{array}$ \\
\hline $\begin{array}{l}\text { Bocatelli } \\
\text { i Moro, } \\
2001\end{array}$ & Włochy & produkt & $\begin{array}{l}\text { Konsumenci skłonni są zapłacić dodatkową kwotę } \\
\text { za atrybuty produktu zmodyfikowanego genetycznie, } \\
\text { z kolei innych } 66 \% \text { konsumentów nie oczekiwało premii } \\
\text { za spożywanie żywności modyfikowanej genetycznie }\end{array}$ \\
\hline $\begin{array}{l}\text { Li i in., } \\
2002\end{array}$ & Chiny & ryż & $\begin{array}{l}\text { 80\% konsumentów nie oczekiwało premii cenowej } \\
\text { z tytułu zakupu ryżu modyfikowanego genetycznie }\end{array}$ \\
\hline $\begin{array}{l}\text { Gonzalez i in., } \\
2009\end{array}$ & Brazylia & $\begin{array}{c}\text { maniok } \\
\text { wzbogacony } \\
\text { witaminą A }\end{array}$ & $\begin{array}{l}\text { Konsumenci skłonni byli zapłacić } 60-70 \% \text { więcej } \\
\text { za maniok wzbogacony w witaminy }\end{array}$ \\
\hline $\begin{array}{l}\text { Krishna } \\
\text { i Qaim, } \\
2008 \\
\end{array}$ & Indie & $\begin{array}{c}\text { warzywa } \\
\text { odporne } \\
\text { na szkodniki }\end{array}$ & $\begin{array}{l}\text { W badaniach ankietowych konsumenci skłonni byli } \\
\text { zapłacić 1,5\% premii za warzywa odporne na szkodniki } \\
\text { w wyniku modyfikacji genetycznej }\end{array}$ \\
\hline $\begin{array}{l}\text { Anand } \mathrm{i} \text { in., } \\
2007\end{array}$ & Indie & pszenica & $\begin{array}{l}\text { Z badań wynika, że jeśli nie podamy żadnych informacji, } \\
\text { to konsumenci zapłacą } 7 \% \text { premii za żywność zmodyfi- } \\
\text { kowaną genetycznie, w przypadku informacji pozytyw- } \\
\text { nych premia wzrasta do } 10 \% \text {, a w przypadku dodatko- } \\
\text { wych informacji negatywnych oczekiwać będą } 39 \% \\
\text { obniżki ceny produktu }\end{array}$ \\
\hline $\begin{array}{l}\text { Kimenju } \\
\text { i De Groote, } \\
2008\end{array}$ & Kenia & $\begin{array}{c}\text { mąka } \\
\text { kukurydziana }\end{array}$ & $\begin{array}{l}\text { Ankietowani konsumenci w } 2003 \text { roku deklarowali goto- } \\
\text { wość płacenia 13,8\% premii za żywność genetycznie } \\
\text { modyfikowaną }\end{array}$ \\
\hline
\end{tabular}

Źródło: opracowanie własne na podstawie: J. Fernandez-Cornejo i in., Genetically Engineered Crops..., op. cit.

266 J. Fernandez-Cornejo i in., Genetically Engineered Crops in the United States, „Economic Research Report” 2014, nr 162, USDA, Economic Research Service, Washington, D.C. 
Z kolei konsumenci wyrażają różny stosunek do modyfikacji genetycznych roślin uprawnych (tabela 6.10). Część z nich jest gotowa zapłacić dodatkową premię za produkty pochodzące ze wzbogaconych na drodze modyfikacji genowych roślin. W szczególności chodzi tu o rośliny modyfikowane, w których dodano np. witaminę A lub kwasy z grupy omega 3. Inni konsumenci są w stanie nabywać produkty pochodzące od roślin transgenicznych pod warunkiem możliwości skorzystania z premii w postaci określonego upustu cenowego.

\section{Zakres uprawy roślin genetycznie modyfikowanych}

\section{na przyktadzie wybranych krajów}

Z przeprowadzonych badań wynika, że uprawa roślin genetycznie modyfikowanych zapewnia wzrost plonów oraz pozwala ograniczyć koszty i zużycie pestycydów. Nie uzyskano natomiast jednoznacznych wyników co do wpływu uprawy tych roślin na efekty ekonomiczne. Tylko w jednym badaniu wykazano bowiem wzrost efektu ekonomicznego z tytułu upraw GMO (tabela 6.11).

Tabela 6.11. Ocena wpływu roślin genetycznie modyfikowanych na plony, zużycie pestycydów oraz efekty ekonomiczne

\begin{tabular}{|l|c|c|c|c|}
\hline \multirow{2}{*}{\multicolumn{1}{|c|}{ Wyszczególnienie }} & \multirow{2}{*}{$\begin{array}{c}\text { Źródła } \\
\text { danych }\end{array}$} & plon & $\begin{array}{c}\text { zużycie } \\
\text { pestycydów }\end{array}$ & ekonomiczny \\
\cline { 3 - 5 } & ankieta & wzrost & spadek & wzrost \\
\hline Marra i in., 1998 & ankieta & wzrost & nie analizowano & podobnie \\
\hline Duffy, 2001 & eksperyment & wzrost & nie analizowano & $\begin{array}{c}\text { zależy od stopnia } \\
\text { zainfekowania }\end{array}$ \\
\hline $\begin{array}{l}\text { Beute, Sears } \\
\text { i Schaafsma, 2002 }\end{array}$ & ankieta & nie analizowano & nie analizowano & spadek \\
\hline McBride i El-Osta, 2002 & ankieta & wzrost & spadek & nie analizowano \\
\hline Pilcher i in., 2002 & eksperyment & wzrost & nie analizowano & nie analizowano \\
\hline Dillehay i in., 2004 & eksperyment & wzrost & nie analizowano & $\begin{array}{c}\text { zależy od stopnia } \\
\text { zainfekowania }\end{array}$ \\
\hline Mitchell i in., 2004 & ankieta & wzrost & spadek & nie analizowano \\
\hline $\begin{array}{l}\text { Fornandez-Cornejo } \\
\text { i Li, 2005 }\end{array}$ & eksperyment & wzrost & nie analizowano & nie analizowano \\
\hline Mungai i in., 2005 & eksperyment & wzrost & nie analizowano & nie analizowano \\
\hline Fang i in., 2007 & & &
\end{tabular}

Źródto: opracowano na podstawie J. Fernandez-Cornejo i in., Genetically Engineered Crops..., op. cit.

\section{Koegzystencja upraw modyfikowanych genetycznie $i$ innych}

Istotnym problemem związanym z uprawą roślin genetycznie modyfikowanych jest ich oddziaływanie na produkcję $\mathrm{w}$ ramach innych systemów produkcji (konwencjonalny i ekologiczny). W tabeli 6.12 przedstawiono strukturę powierzchni upraw według systemów produkcji w USA. 
Tabela 6.12. Struktura powierzchni uprawy roślin w różnych systemach produkcji w USA średnio w latach 2012-2014 (w proc.)

\begin{tabular}{|l|c|c|c|}
\hline \multirow{2}{*}{ Rodzaj uprawy } & \multicolumn{3}{|c|}{ System produkcji } \\
\cline { 2 - 4 } & $\begin{array}{c}\text { rośliny genetycznie } \\
\text { modyfikowane }\end{array}$ & $\begin{array}{c}\text { uprawy } \\
\text { konwencjonalne }\end{array}$ & $\begin{array}{c}\text { uprawy } \\
\text { ekologiczne }\end{array}$ \\
\hline Kukurydza & 93,0 & 6,7 & 0,3 \\
\hline Soja & 94,0 & 5,8 & 0,2 \\
\hline Bawełna & 96,0 & 3,9 & 0,1 \\
\hline Rzepak & 94,0 & 6,0 & - \\
\hline Buraki cukrowe & 98,0 & 2,0 & 2,0 \\
\hline Kukurydza cukrowa & 8,0 & 90,0 & 17,0 \\
\hline Kabaczek & 12,0 & 71,0 & 3,6 \\
\hline Warzywa ogółem & 0,6 & 96,0 & 0,27 \\
\hline Uprawy owoców ogółem & 0,03 & 95,7 & \\
\hline
\end{tabular}

Źródto: opracowano na podstawie USDA, Economic Research Service using agricultural yield..., op. cit.

Z przedstawionych danych wynika, że obok upraw roślin genetycznie modyfikowanych w USA występują również uprawy konwencjonalne i ekologiczne. Wspótistnienie różnych systemów produkcji pociąga za sobą pewne ryzyko zmieszania produktów z modyfikacjami genowymi z tymi, które są tych modyfikacji pozbawione. Jest to szczególnie istotne w przypadku produkcji ekologicznej, gdzie konsumenci oczekują produktu uzyskanego zgodnie z zasadami obowiązującymi w tym systemie, a ten nie dopuszcza manipulacji genowych. Stąd też producenci ekologiczni, jak również producenci konwencjonalni bez GMO narażeni są na konieczność ponoszenia dodatkowych kosztów w celu ochrony swoich produktów przed ich zmieszaniem z produktami zmodyfikowanymi genetycznie. Wymaga to stosowania w uprawie odpowiednich stref buforowych, a w czasie zbiorów i magazynowania produktów zapewnienia ich izolacji od produktów zawierających modyfikację genetyczną. Wymaga to również prowadzenia odpowiedniej dokumentacji.

\subsubsection{Efektywność postępu biologicznego w gospodarstwach rolnych}

Ocena efektywności postępu biologicznego w gospodarstwach rolnych jest trudna, gdyż postęp ten jest najczęściej upowszechniany równolegle z innymi rodzajami postępu, w tym technologicznym, mechanizacyjnym i organizacyjnym. Pomimo tych zastrzeżeń niektórzy autorzy podejmują próby oceny efektywności poszczególnych rodzajów postępu ${ }^{267}$. W tabeli 6.13 przedstawiono syntetyczne wyniki uzyskane na podstawie badań gospodarstw rodzinnych.

${ }^{267}$ Z. Wójcicki, A. Szeptycki, Efektywność postępu technicznego w modelowych gospodarstwach rodzinnych, „Problemy Inżynierii Rolniczej” 2016, z. 4(94), s. 5-18. 
Tabela 6.13. Wskaźniki efektywności postępu

w modelowych gospodarstwach rodzinnych

\begin{tabular}{|l|c|c|c|c|c|c|}
\hline \multirow{2}{*}{ Wyszczególnienie } & \multicolumn{6}{|c|}{ Wskaźnik efektywności różnych rodzajów postępu } \\
\cline { 2 - 7 } & $\begin{array}{c}\text { postęp } \\
\text { biologiczny }\end{array}$ & $\begin{array}{c}\text { postęp } \\
\text { chemiczny }\end{array}$ & $\begin{array}{c}\text { postęp } \\
\text { agrozoo- } \\
\text { techniczny }\end{array}$ & $\begin{array}{c}\text { postęp } \\
\text { mechaniczny }\end{array}$ & $\begin{array}{c}\text { postęp } \\
\text { organizacyjny }\end{array}$ & razem \\
\hline Średnio & 1,32 & 2,32 & 2,38 & 0,92 & 1,88 & 1,54 \\
\hline $\begin{array}{l}\text { Średnio nakłady } \\
\text { (w proc.) }\end{array}$ & 23,4 & 13,3 & 12,9 & 33,3 & 17,1 & 100,0 \\
\hline
\end{tabular}

Źródło: Z. Wójcicki, A. Szeptycki, Efektywność postępu technicznego w modelowych gospodarstwach rodzinnych, ,, Problemy Inżynierii Rolniczej” 2016, z. 4(94), s. 5-18.

$\mathrm{Z}$ badań tych wynika, że postęp biologiczny, podobnie jak inne rodzaje postępu wdrażanego w badanych gospodarstwach rolnych, przynosił pozytywne efekty ekonomiczne. Oceniając wpływ poszczególnych rodzajów postępu, należy mieć na uwadze efekty synergii, jakie pojawiają z tytułu współdziałania różnych rodzajów postępu.

\subsubsection{Wykorzystanie nośników postępu biologicznego w produkcji roślinnej w polskim rolnictwie}

Do produkcji są wprowadzane nowe odmiany roślin uprawnych, które są efektem prac hodowlanych. Potencjał zgromadzony w wyhodowanych odmianach roślin uprawnych nie jest jednak w pełni wykorzystany, gdyż występują wyraźne różnice między wysokością plonów uzyskiwanych w prowadzonych doświadczeniach polowych a plonami uzyskiwanymi średnio w produkcji rolniczej w Polsce.

Poziom plonów roślin uprawnych, obok powierzchni zasiewów, decyduje o wielkości zbiorów, a pośrednio o dochodowości produkcji i gospodarstw. Na poziom plonowania wpływają zarówno czynniki zależne, jak i niezależne od producenta. Jednym z ważniejszych elementów technologii produkcji, na który ma wpływ producent, jest zastosowanie wysokiej jakości materiału siewnego odpowiednio dobranej odmiany rośliny uprawnej.

Zmiany poziomu plonowania $\mathrm{w}$ doświadczeniach polowych oraz produkcji masowej dla zbóż ogółem w latach 2000-2016 przedstawiono na wykresie 6.13. Przyrost plonów uzyskiwany w doświadczeniach polowych, w tempie $62 \mathrm{~kg}$ na rok, w ujęciu średniorocznym wynosił $0,92 \%$. W warunkach produkcyjnych dynamika wzrostu plonów była nieco wyższa i wynosiła $71 \mathrm{~kg} / \mathrm{ha} / \mathrm{rok}$, czyli wzrastała $\mathrm{w}$ tempie aż 2,1\% rocznie. Mimo różnej dynamiki utrzymywała się luka plonowania, która w latach 2014-2016 wynosiła średnio 36,9 dt/ha. Wielkość przedstawionej różnicy nie zmniejszyła się znacząco w stosunku do lat 2000-2002, 
kiedy wynosiła ona $34 \mathrm{dt} / \mathrm{ha} /$ rok. Można zauważyć, że mimo wyższej dynamiki wzrostu plonów w praktyce gospodarczej luka plonowania się nie zmniejszyła. Dynamika zmian liczona jest bowiem od wartości bazowej.

Przedstawione zależności świadczą o tym, że poziom wykorzystania postępu biologicznego w produkcji zbóż nie jest wysoki, a co więcej nie zmieniał się znacząco od 2000 roku. Wskazuje to na przeciętnie słabe wykorzystanie potencjału plonowania odmian zbóż. W poszczególnych gospodarstwach, szczególnie dysponujących dobrymi glebami i stosującymi poprawną technologię produkcji, wykorzystanie potencjału plonowania odmian może być wysokie. W skali kraju trudno jest jednak ustalić, czy dominuje znaczenie luki technologicznej, czy środowiskowej.

Wykres 6.13. Porównanie poziomu plonów zbóż ogółem w doświadczeniach polowych oraz w produkcji rolniczej w Polsce

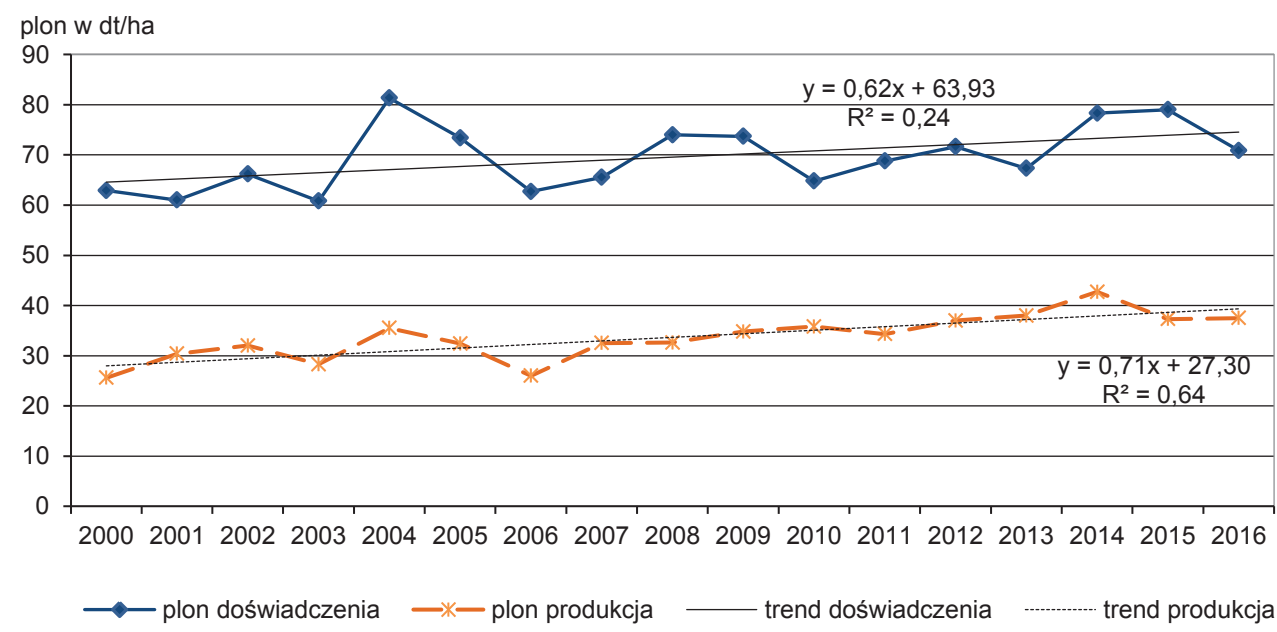

Źródto: opracowanie własne.

Na wykresie 6.14 przedstawiono zmiany w zakresie plonowania ważniejszych gatunków zbóż w Polsce: pszenicy ozimej, żyta, pszenżyta ozimego i jęczmienia jarego. W pierwszej kolejności pokazano zmiany plonowania pszenicy ozimej w doświadczeniach polowych i w praktyce gospodarczej. Podobnie, jak zaobserwowano to w odniesieniu do zbóż ogółem, luka plonowania nie zmniejsza się, gdyż zarówno plony w doświadczeniach, jak i w produkcji wzrastały. W doświadczeniach było to $84 \mathrm{~kg} / \mathrm{ha}$ rocznie, a w produkcji $76 \mathrm{~kg} / \mathrm{ha}$ rocznie. $W$ ujęciu procentowym było to 1,1 i 1,8\% średnio rocznie. Luka plonowania w ujęciu ilościowym nie zmieniała się i zarówno w latach 2000-2002, jak i 2014-2016 wynosiła 40,7 dt/ha. 
Dalej zaprezentowano relacje plonów dla żyta. W przypadku tego gatunku ilościowa luka plonowania wynosiła około $40 \mathrm{dt} / \mathrm{ha}$ i nie zmieniała się $\mathrm{w}$ całym analizowanym okresie. Wyraźne jest natomiast to, że następował wzrost plonowania $\mathrm{w}$ produkcji rolniczej. $\mathrm{W}$ całym okresie wzrost wynosił $2,0 \%$ rocznie, a w doświadczeniach było to $0,2 \%$ rocznie. W przypadku żyta, inaczej niż pszenicy ozimej, postęp w plonowaniu w doświadczeniach był niższy niż w produkcji i wynosił tylko $11 \mathrm{~kg} /$ ha rocznie. Dla produkcji obserwowano wzrost w wysokości $49 \mathrm{~kg} / \mathrm{ha}$ rocznie. Mimo takiego postępu w plonowaniu w przypadku żyta obserwuje się najniższe plony wśród innych gatunków zbóż. Wynika to z faktu, że jest ono uprawiane zwykle na najsłabszych glebach, a więc wzrost plonowania jest ograniczany czynnikami środowiskowymi, na które rolnicy nie mają wpływu. Nie należy spodziewać się istotnego wzrostu plonowania żyta w Polsce.

Kolejnym omawianym gatunkiem zbóż jest jęczmień jary. Jest on uprawiany na powierzchni ponad 700 tys. ha. Także w przypadku tego gatunku następował wzrost plonowania zarówno w doświadczeniach, jak i w warunkach produkcyjnych. Dynamika wzrostu plonów w warunkach produkcyjnych była nieco niższa od obserwowanej w doświadczeniach polowych $(49 \mathrm{~kg} / \mathrm{ha}$ rocznie i $54 \mathrm{~kg} / \mathrm{ha}$ rocznie). Luka plonowania wynosiła na początku okresu $31 \mathrm{dt} / \mathrm{ha}$ i zwiększyła się do 36,8 dt/ha w latach 2014-2016. Podobne wyniki uzyskano dla pszenżyta ozimego, które zajmuje około 1,2 mln ha. W tym przypadku luka plonowania wynosiła około $42 \mathrm{dt} / \mathrm{ha}$ w całym okresie. Dynamika przyrostu plonów w doświadczeniach była dość niska i wynosiła $0,4 \%$ średnio rocznie, a w produkcji było to $1,3 \%$ średnio rocznie.

Biorąc pod uwagę poziom wykorzystania potencjału plonowania odmian zbóż w produkcji, należy stwierdzić, że dla żadnego z gatunków nie nastąpiła istotna zmiana. Nie oznacza to jednak, że nie następował postęp w plonowaniu. W latach 2000-2016 nastąpił wzrost plonowania zbóż w Polsce o około 20\%, przy czym wyższe wyniki uzyskano dla zbóż ozimych. W badaniach wykazano, że udział postępu biologicznego w kreowaniu wzrostu plonowania odmian w doświadczeniach polowych wynosił od 30 do $60 \%$, w zależności od gatunku i poziomu intensywności produkcji ${ }^{268}$. Przenosząc te wyniki na warunki produkcyjne, oznacza to, że w efekcie upowszechniania postępu biologicznego w produkcji zbóż w latach 2000-2016 nastąpił wzrost plonowania zbóż o 10\%. Pozostałą część wzrostu należy przypisać zmianom w technologii produkcji. Wynika z tego, że dzięki wprowadzaniu postępu biologicznego w produkcji zbóż można było uzyskać przyrost zbiorów o około 1,5 $\mathrm{mln}$ ton.

${ }^{268}$ L. Wicki, Postęp $w$ plonowaniu odmian pszenicy ozimej $i$ żyta $w$ doświadczeniach odmianowych w Polsce, ,Roczniki Naukowe Stowarzyszenia Ekonomistów Rolnictwa i Agrobiznesu” 2017, t. XIX, z. 4, s. 224-230. 

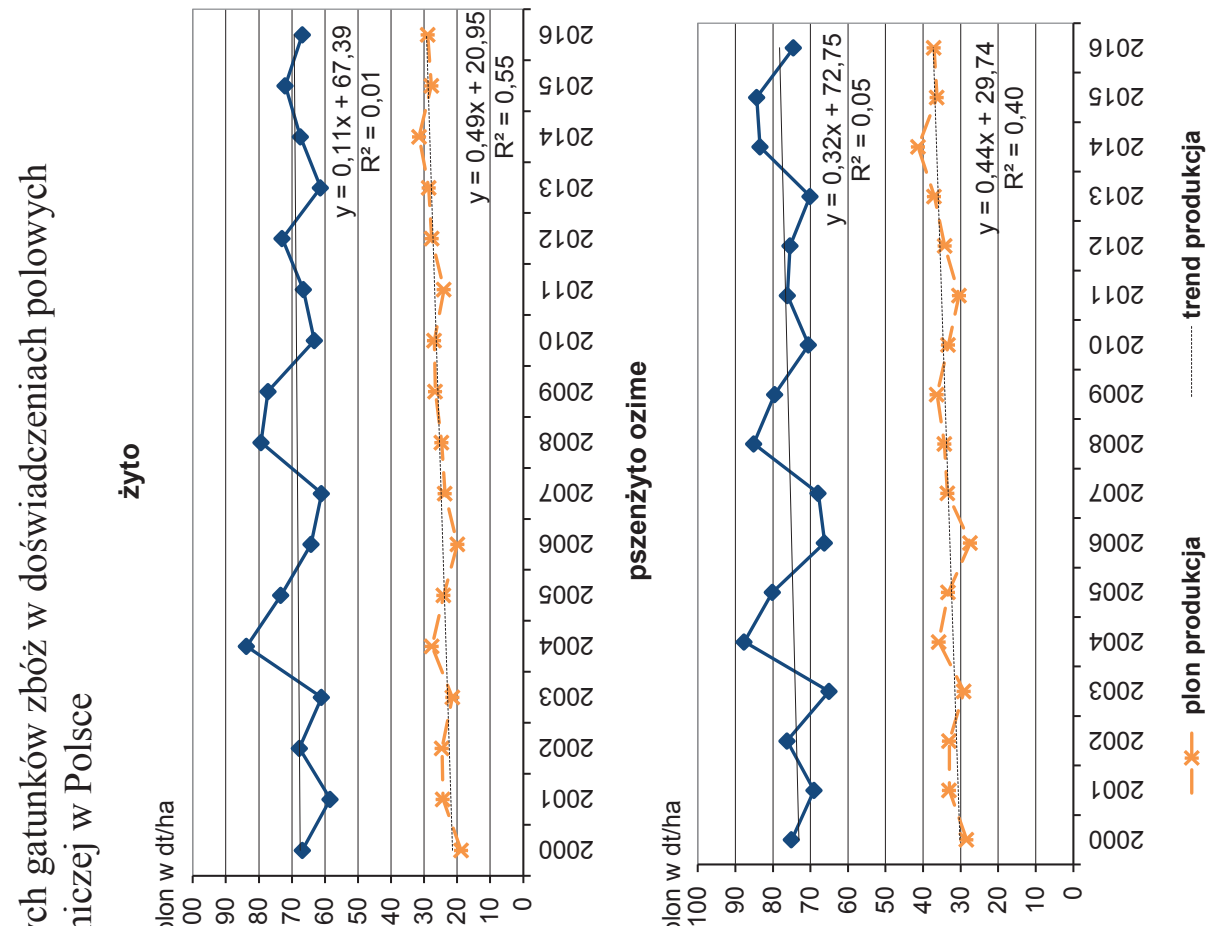

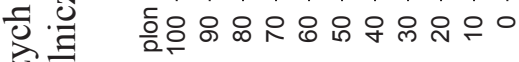

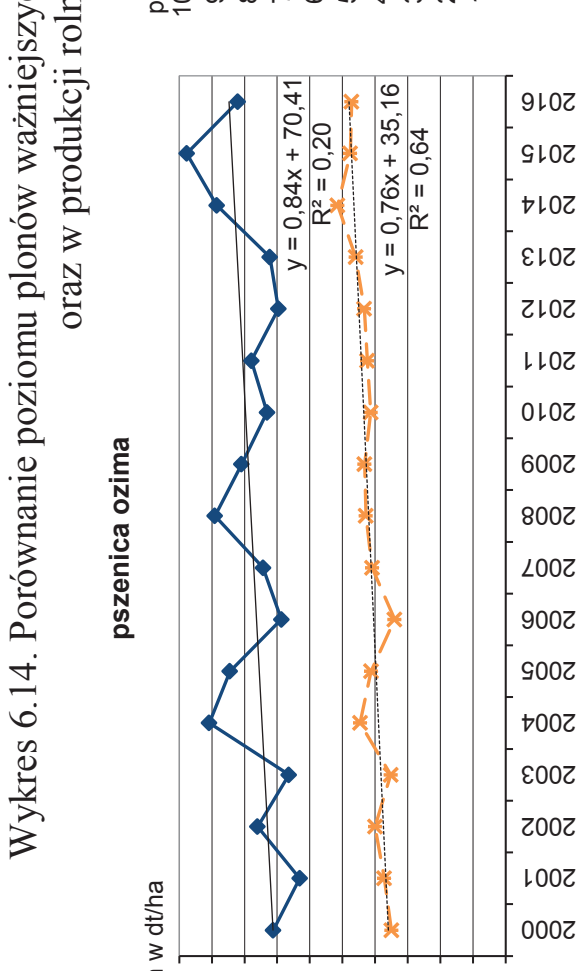

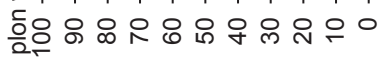

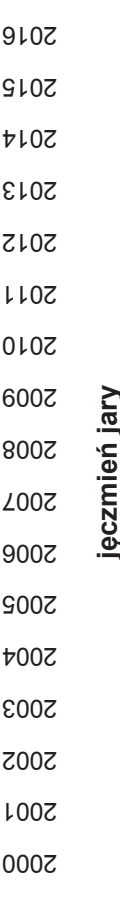

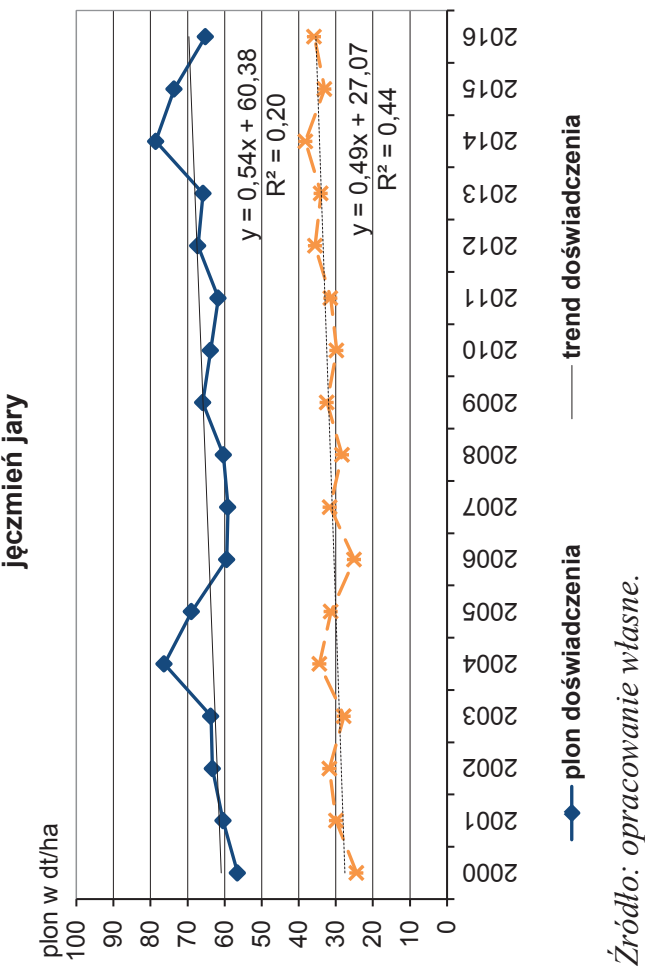


Wzrost efektywności produkcji zbóż może wynikać zarówno z poprawy wykorzystania potencjału plonowania, jak i rozwoju technologii produkcji. Potencjalnie więc w większym zastosowaniu kwalifikowanego materiału siewnego i ulepszaniu technologii produkcji należy upatrywać możliwości wzrostu produkcji zbóż oraz polepszenia jej dochodowości. Głównym ograniczeniem mogą być jednak warunki środowiskowe, przede wszystkim niska jakość gleb.

Nieco inaczej sytuacja przedstawia się w małych gospodarstwach. Jak wykazała B. Gołębiewska ${ }^{269}$, w gospodarstwach tych duża część produkcji jest zużywana na potrzeby wewnętrzne. Takie gospodarstwa nie będą więc zainteresowane stosowaniem nośników postępu biologicznego. Małe gospodarstwa, mimo że stanowią większość, użytkują jednak mniej niż połowę gruntów.

\section{Poziom wykorzystania potencjału plonowania odmian}

Unowocześnianie produkcji rolniczej w Polsce powinno prowadzić do coraz wyższego poziomu wykorzystania potencjału plonowania odmian w produkcji rolniczej. Na wykresie 6.15 przedstawiono poziom wykorzystania potencjału plonowania dla poszczególnych gatunków zbóż i jego zmianę między okresami 2000-2004 a 2012-2016. Można zauważyć, że w przypadku prawie każdego gatunku nastąpił wzrost wskaźnika wykorzystania potencjału odmianowego. Wzrost o 5 lub więcej pkt proc. uzyskano w przypadku: pszenicy ozimej, pszenżyta ozimego, żyta i jęczmienia jarego. Dla pozostałych gatunków było to 2-4 pkt proc. Jedynie dla pszenicy jarej zaobserwowano spadek o 1 pkt proc. Poziom wykorzystania potencjału plonowania odmian w dłuższym okresie także wzrastał, odnotowano wzrost o ponad 6 pkt proc. w latach $1992-2015^{270}$. Dla zbóż intensywnych określono wykorzystanie na poziomie 50\%, a dla zbóż ekstensywnych około $40 \%$.

Na podstawie zaobserwowanych zmian można stwierdzić, że w polskim rolnictwie następuje stopniowa poprawa efektywności w zakresie wykorzystania potencjału plonowania odmian. Mimo że proces ten następuje powoli, należy się spodziewać jego kontynuacji w kolejnych latach. Ponieważ lepsze wykorzystanie potencjału może oznaczać także obniżenie kosztów jednostkowych produkcji oraz przyczynić się do polepszenia efektywności produkcji w polskim rolnictwie. Warunkiem jest korzystanie z postępu biologicznego, co następuje poprzez zakup nasion kwalifikowanych odpowiednich odmian.

\footnotetext{
${ }^{269}$ B. Gołębiewska, Organizacyjno-ekonomiczne skutki zróżnicowania powiązań gospodarstw rolniczych z otoczeniem, Wydawnictwo SGGW, Warszawa 2010.

${ }^{270}$ L. Wicki, Wykorzystanie potencjału plonowania zbóż $w$ produkcji rolniczej $w$ Polsce, „Roczniki Naukowe Stowarzyszenia Ekonomistów Rolnictwa i Agrobiznesu” 2016, t. XVIII, z. 5, s. 267-273.
} 
Wykres 6.15. Porównanie wykorzystania potencjału plonowania odmian według gatunków zbóż w latach 2000-2004 i 2012-2016

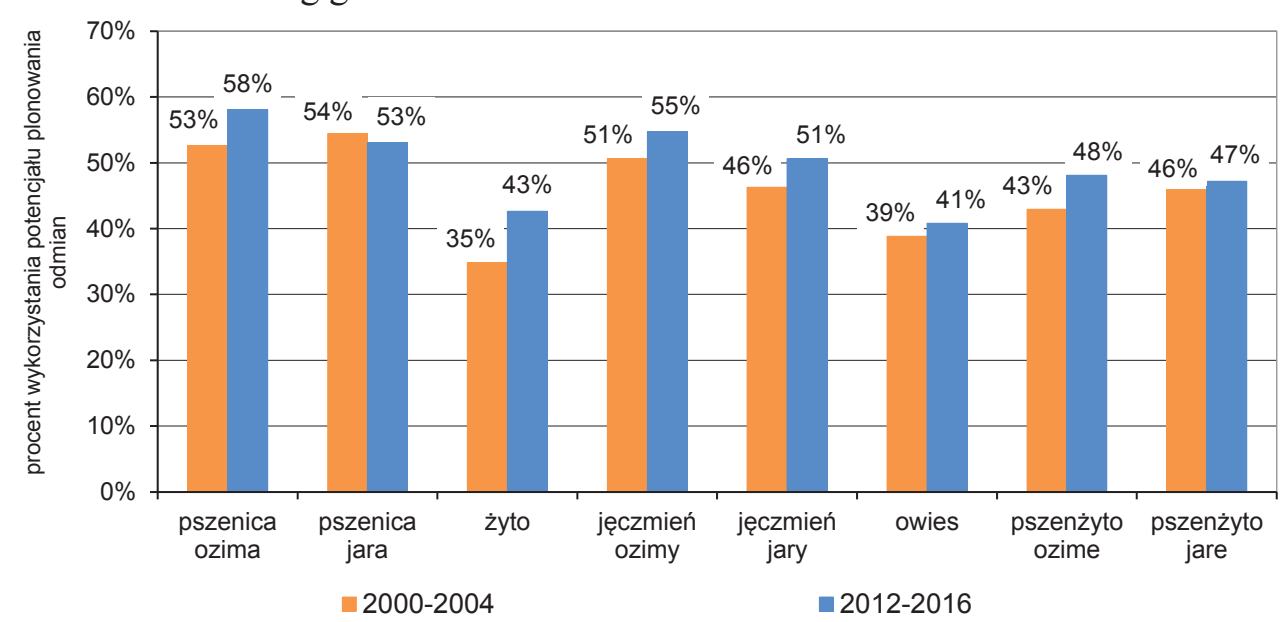

Źródto: opracowanie własne.

\section{Wykorzystanie kwalifikowanego materialu siewnego w produkcji}

Warunkiem skutecznego upowszechniania postępu biologicznego jest zakup nasion kwalifikowanych nowych odmian. W Polsce udział nasion kwalifikowanych $\mathrm{w}$ materiale siewnym był i jest relatywnie niski. L. Wicki ${ }^{271}$ stwierdza, że w Polsce w latach 2000-2008 udział kwalifikowanych nasion w zużywanym materiale siewnym ogółem wynosił zaledwie $10 \%$, podczas gdy w krajach należących do UE-12 wynosił średnio aż 55\%. Niski poziom wykorzystania nasion kwalifikowanych jest jednym z czynników ograniczających potencjał plonowania i wydajność zużywanych nakładów. Także w innych badaniach wskazuje się na wciąż silne ograniczenia popytowe w rozwoju rynku nasion ${ }^{272}$.

Zużycie kwalifikowanego ziarna zbóż w Polsce od 2000 roku charakteryzowało się pewnymi wahaniami. W latach 2000-2007 nastąpił spadek jego zużycia $\mathrm{z}$ około 200 tys. ton do zaledwie 134 tys. ton. Wynikało to z ograniczania w latach 2000-2003 dotacji do sprzedaży kwalifikowanego materiału siewnego, a w latach 2004-2006 zaniechania tego wsparcia. Od 2007 roku ARR rozpoczęła realizację programu wsparcia do powierzchni obsiewanej nasionami kwalifikowanymi, co przyczyniło się do powolnej odbudowy rynku i osiągnięcia w latach 2011-2016 sprzedaży ziarna kwalifikowanego w ilości około 170 tys. ton (wykres 6.16).

\footnotetext{
${ }^{271}$ L. Wicki, Zmiany w zużyciu nasion kwalifikowanych $w$ Polsce, „Roczniki Nauk Rolniczych. Seria G” 2009, t. 96, nr 4, s. 226-237.

${ }^{272}$ D. Majchrzycki, Rynek kwalifikowanego materiatu siewnego pszenicy ozimej w Polsce, „Roczniki Naukowe Stowarzyszenia Ekonomistów Rolnictwa i Agrobiznesu” 2015, t. XVII, z. 3, s. 254-259.
} 
Wykres 6.16. Zużycie kwalifikowanego materiału siewnego zbóż i kwalifikowanych sadzeniaków ziemniaka w Polsce w latach 2000-2016 tys. ton

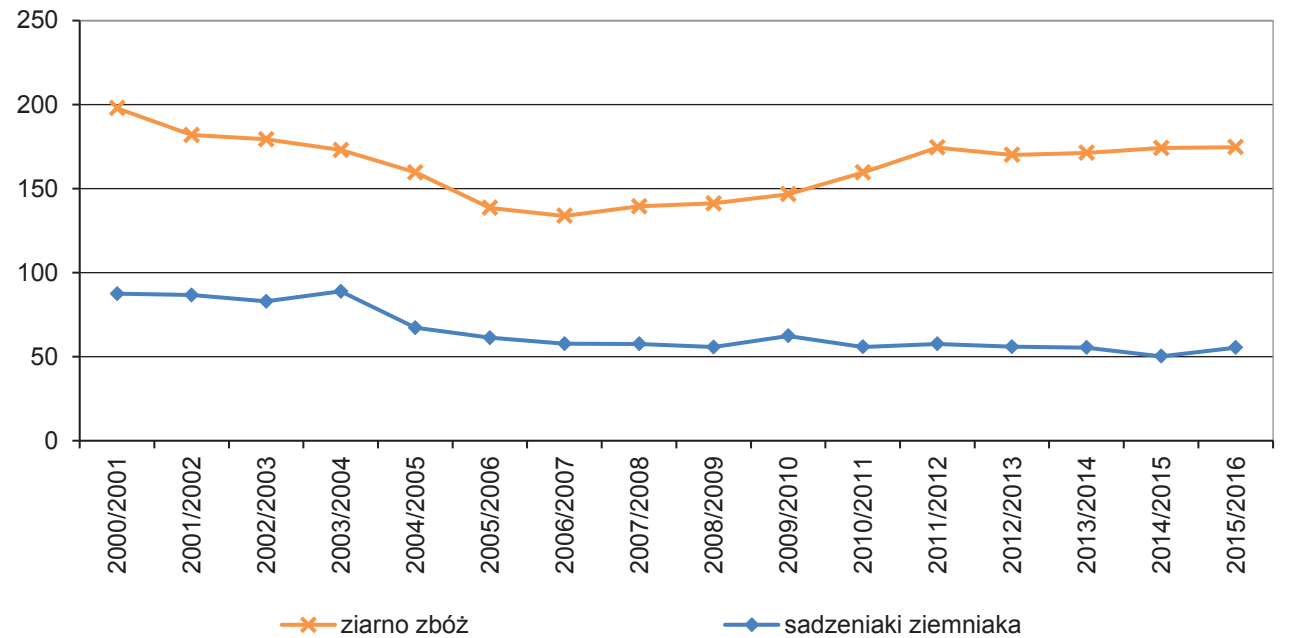

Źródło: opracowanie własne na podstawie danych GUS.

Największy udział w sprzedaży ziarna kwalifikowanego miał materiał siewny gatunków uważanych za intensywne: pszenicy ozimej (65 tys. ton), pszenżyta (30 tys. ton) i jęczmienia jarego (25 tys. ton). Są to jednocześnie gatunki uprawiane na największą skalę. Najwyższy udział powierzchni obsianej materiałem kwalifikowanym odnotowano dla jęczmienia ozimego, pszenicy jarej i jęczmienia jarego oraz pszenicy ozimej. Dla zbóż ekstensywnie uprawianych udział nasion kwalifikowanych w materiale siewnym był bardzo niski i wynosił około $10 \%$. Zużycie ziarna kwalifikowanego w przeliczeniu na całą powierzchnię uprawy zbóż podstawowych z mieszankami wynosiło tylko $12 \%$. Nie można wskazać stałej tendencji w zużyciu nasion kwalifikowanych. Dla części gatunków zużycie to zwiększyło się w omawianym okresie (jęczmień ozimy i żyto), a dla pozostałych gatunków obserwowano spadek lub stały poziom zużycia (wykres 6.17).

$\mathrm{Na}$ podstawie przedstawionych wielkości można określić średni okres wymiany nasion. Najdłuższy kalkulowany okres wymiany nasion ustalono dla żyta 11 lat. Dla pszenżyta i owsa wynosi on 8 lat, a dla pozostałych gatunków zbóż 4-5 lat. Długi okres wymiany nasion oznacza, że rolnicy nie korzystają w pełni z potencjału, jaki dają nasiona kwalifikowane. $Z$ drugiej jednak strony, gatunki uprawiane ekstensywnie charakteryzują się długim okresem wymiany nasion, lecz rolnicy produkujący zboża na glebach lekkich nie mogliby wykorzystać w pełni potencjału odmian, ze względu na ograniczenia wynikające z jakości gleb. 
Relatywnie niski popyt na kwalifikowane ziarno gatunków takich jak żyto czy owies może być wyjaśniany brakiem możliwości ujawnienia się potencjału plonowania w warunkach, w jakich te zboża są uprawiane.

Wykres 6.17. Udział kwalifikowanego materiału siewnego w ogólnej ilości materiału zużywanego do siewu według gatunków w latach 2000 i 2016

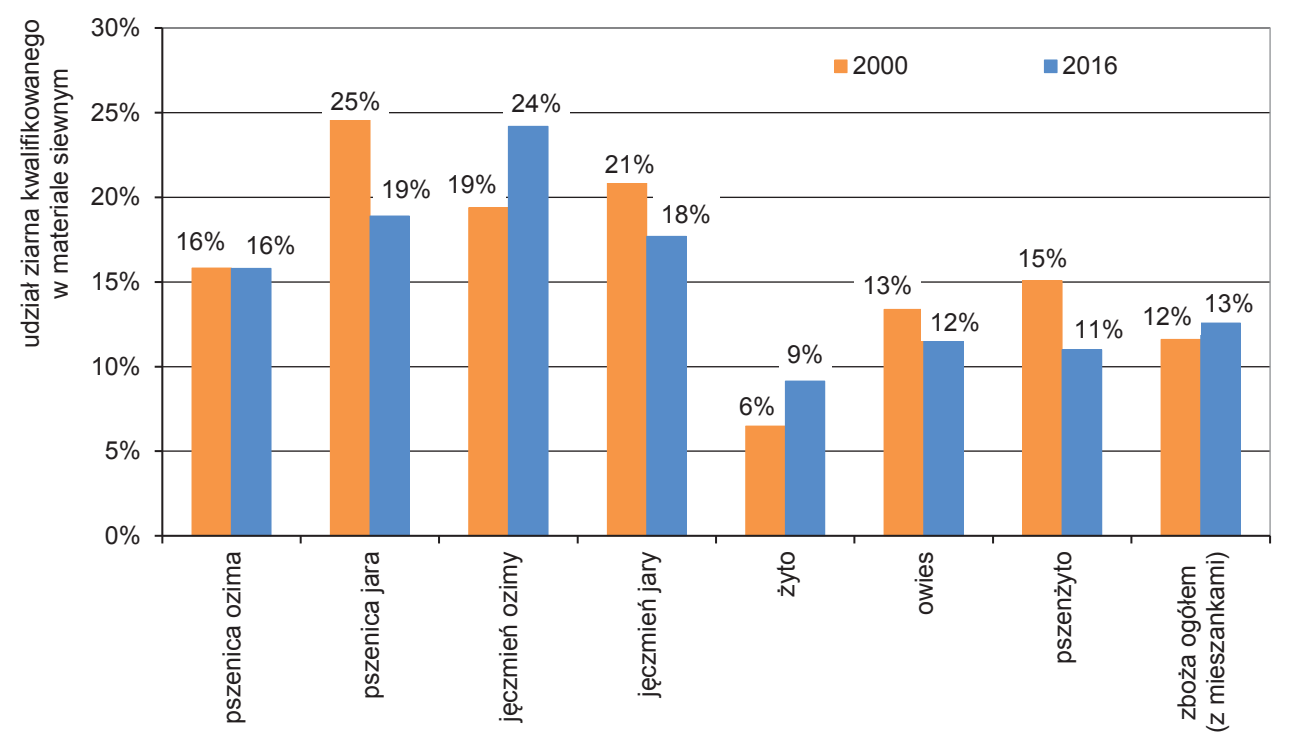

Źródto: opracowanie własne.

\section{Konkluzje}

Reasumując, można stwierdzić, że w Polsce dostępne są odmiany o wysokim potencjale plonowania. Poziom plonów w doświadczeniach osiąga dla każdego z gatunków zbóż 80 dt/ha. Ze względu na występowanie luki środowiskowej i technologicznej czy też gorszych warunków środowiskowych i gorszej technologii produkcji poziom plonów w praktyce rolniczej średnio nie przekracza $40 \mathrm{dt} / \mathrm{ha}$. W latach 2000-2016 następował stopniowy wzrost poziomu plonowania, w tempie około $1-1,5 \%$ rocznie, co oznacza przyrost plonów o $40-60 \mathrm{~kg} /$ ha rocznie zależnie od gatunku. Około 50\% tego wzrostu można przypisać wprowadzaniu postępu biologicznego w zakresie nowych odmian.

Mimo postępu w plonowaniu zwiększała się luka plonowania. Poziom plonów w praktyce rolniczej osiągnął w latach 2012-2016 około 50\% poziomu plonów w doświadczeniach, chociaż był wyższy o 6 pkt proc. niż w latach 2000-2004. Obserwowana luka plonowania była niższa w przypadku zbóż uprawianych intensywnie, takich jak pszenica czy jęczmień. Dla pszenicy ozimej poziom wykorzy- 
stania potencjału plonowania wynosił nawet 58\%. Oznacza to także, że barierą dla wzrostu plonów zbóż ekstensywnych nie jest niewłaściwa technologia, ale raczej ograniczenia wynikające z jakości gleb, na których są uprawiane i towarzyszących warunków środowiska.

Zużycie kwalifikowanego materiału siewnego zbóż w Polsce jest niskie i nie przekracza przeciętnie $12 \%$ ogólnej ilości materiału siewnego. Sytuacja taka utrzymuje się od wielu lat i może być przyczyną gorszego wykorzystania potencjału plonowania. Znaczące zmiany w tym zakresie nie wydają się być prawdopodobne w najbliższym czasie.

Biorąc pod uwagę dokonane ustalenia, należy stwierdzić, że postęp biologiczny może mieć nawet 50\% udział w obserwowanym wzroście plonowania. Dostępność wysokowydajnych odmian jest wystarczająca, a ograniczenia wynikają z niskiego zakresu upowszechnienia materiału siewnego. Bez dodatkowych, szerzej zaplanowanych analiz nie można jednak jednoznacznie stwierdzić, który z elementów luki plonowania ma największe znaczenie: luka środowiskowa, technologiczna, czy brak wykorzystania nowych odmian. Obserwując różnice w plonowaniu zbóż intensywnych i ekstensywnych, można zauważyć, że w części regionów napotyka się na ograniczenia środowiskowe, takie jak niska jakość gleb lub niedobory wody, które są barierą dla wzrostu plonów. Dodatkową barierą może być mała skala produkcji. W małych, nienastawionych na rynek gospodarstwach wykorzystanie kwalifikowanego materiału siewnego jest wielokrotnie niższe niż w gospodarstwach towarowych. Wynika to z innej hierarchii celów w takich gospodarstwach ${ }^{273}$, poza tym napotyka się w nich inne bariery wdrażania postępu, takie jak brak opanowania technologii, brak kapitału itp.

Potencjalnie, przy braku istotnych ograniczeń środowiskowych, poziom wykorzystania potencjału plonowania zbóż może wzrosnąć o około 10 pkt proc., a plony o około 7-10 dt/ha. Wykorzystanie odmian odpowiednich do warunków klimatycznych oraz poziomu stosowanej technologii umożliwi obniżenie jednostkowych kosztów wytwarzania ze względu na to, że około 5-10\% wzrostu może być uzyskane prawie beznakładowo. Nie musi to przekładać się na polepszenie sytuacji dochodowej gospodarstw, gdyż popyt na produkty rolnicze jest mało elastyczny i wzrost produkcji może prowadzić lokalnie do spadku cen skupu. W przypadku stopniowego wyłączania z produkcji gleb marginalnie położnych oraz najsłabszych możliwe jest zapewnienie tego samego poziomu produkcji z mniejszej powierzchni.

${ }^{273}$ B. Gołębiewska, Organizacyjno-ekonomiczne skutki..., op. cit. 


\subsection{Postęp biologiczny w produkcji zwierzęcej}

Na wykresie 6.18 przedstawiono zależność między nakładami a produktywnością jednostkową zwierząt. Wynika z niego, że doskonalenie potencjału genetycznego zwierząt sprzyja łagodzeniu skutków prawa malejącej efektywności nakładów, zgodnie z którym od pewnego poziomu nakładów każdy dodatkowy nakład przynosi mniejszy przyrost wydajności zwierząt.

Wykres 6.18. Zależność między poziomem nakładów a wydajnością jednostkową zwierząt o różnym potencjale genetycznym

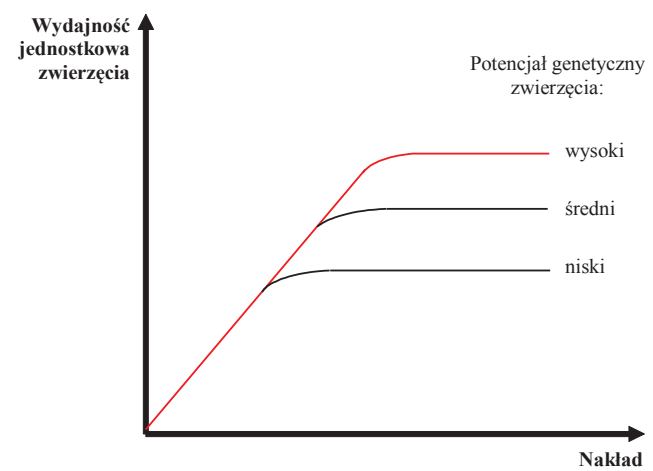

Źródlo: H. Runowski, Koncentracja produkcji zwierzęcej, Wydawnictwo Fundacja „Rozwój SGGW", Warszawa 1994.

Wraz ze wzrostem wydajności mlecznej krów zmniejsza się zużycie energii na 1 litr produkowanego mleka (wykres 6.19). Wynika to przede wszystkim ze zmniejszającego się, wraz ze wzrostem wydajności krów, udziału zużycia pasz na cele bytowe.

Wykres 6.19. Zależność między wydajnością mleczną krów a zużyciem energii na produkcję 1 litra mleka

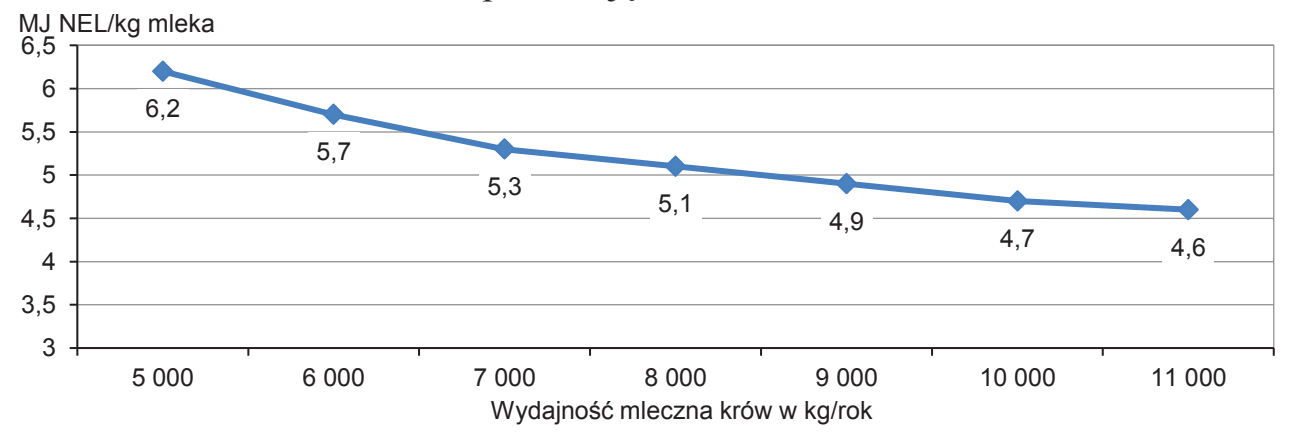

Źródto: T. Jigl, Effizienzsteigerung in der Milchviehhaltung durch optimierte Fütterung, Landwirtschaftliches Zentrum für Viehhaltung, Grünlandwirtschaft, Milchwirtschaft, Wild, Fischerei Baden-Württemberg, Aulendorf. 
Pozytywny wpływ postępu biologicznego na efektywność produkcji w gospodarstwach rolnych potwierdzają również dane zaprezentowane w tabeli 6.14.

Tabela 6.14. Efektywność postępu biologicznego w chowie krów w Turyngii

\begin{tabular}{|c|c|c|c|c|c|c|}
\hline \multirow[b]{2}{*}{ Wyszczególnienie } & \multirow{2}{*}{$\begin{array}{c}\text { Jednostka } \\
\text { miary }\end{array}$} & \multicolumn{5}{|c|}{ Wydajność mleczna krów } \\
\hline & & $<6000$ & $\begin{array}{l}6000- \\
-7000\end{array}$ & $\begin{array}{l}7001- \\
-8000\end{array}$ & $\begin{array}{l}8001- \\
-9000\end{array}$ & $>9000$ \\
\hline Cena mleka & euro/100 kg & 31,8 & 31,7 & 31,5 & 31,3 & 30,9 \\
\hline Przychody ogółem & euro/krowę/rok & 1742 & 2178 & 2468 & 2751 & 3160 \\
\hline Przychody na litr mleka & euro/litr & 33,9 & 33,3 & 32,9 & 32,5 & 31,9 \\
\hline Koszty ogółem & euro/krowę/rok & 2337 & 2454 & 2598 & 2779 & 3083 \\
\hline Koszty na litr mleka & euro/litr & 45,50 & 37,51 & 34,65 & 32,85 & 31,16 \\
\hline Wynik ekonomiczny & euro/krowę/rok & -595 & -276 & -131 & -28 & -78 \\
\hline Wynik ekonomiczny na litr mleka & euro/litr & $-11,59$ & $-4,22$ & $-1,75$ & $-0,33$ & $-0,78$ \\
\hline
\end{tabular}

Źródło: Wirkung von Lebensleistung und Nutzungsdauer der Kühe auf die Ökonomie der Milchproduktion, Thüringer Landesanstalt für Landwirtschaft, Jena, Juni 2008.

Z przedstawionych liczb wynika, że wraz ze wzrostem wydajności mlecznej krów poprawiają się wyniki ekonomiczne produkcji mleka. Przy najwyższych wydajnościach uzyskiwano jednak niższą cenę mleka, co wskazuje na to, że wraz ze wzrostem wydajności mlecznej obserwuje się spadek zawartości tłuszczu i białka w mleku. Coraz częściej podkreśla się, że wraz ze wzrostem wydajności mlecznej skraca się długość życia krów, co wywołuje zastrzeżenia natury etycznej ${ }^{274}$. Doceniając znaczenie postępu biologicznego w produkcji zwierzęcej, warto przeanalizować zmiany, jakie dokonują się w poziomie wydajności mlecznej krów objętych kontrolą użytkowości mlecznej w Polsce w relacji do wydajności krów ogółem (tabela 6.15).

Z danych wynika, że pomiędzy wydajnością uzyskiwaną od krów objętych kontrolą użytkowości mlecznej a wydajnością krów ogółem utrzymują się duże różnice. Watro jednak zauważyć, że różnice te w ostatnich latach zmniejszają się, co świadczy o coraz lepszym wykorzystywaniu w praktyce rolniczej potencjału genetycznego krów, czemu sprzyjają obserwowane procesy koncentracji krów i wykorzystanie w rozrodzie nasienia buhajów o wysokim potencjale genetycznym. Pomimo odnotowanego postępu należy zauważyć, że Polskę od krajów Europy Zachodniej w zakresie wydajności mlecznej dzieli duży dystans, choć ten zmniejsza się w czasie.

${ }^{274}$ H. Runowski, Poszukiwanie równowagi ekonomiczno-ekologicznej i etycznej w produkcji mleka, „Roczniki Nauk Rolniczych. Seria G” 2007, t. 93, z. 2, s. 13-26. 
Tabela 6.15. Wydajność mleczna krów w Polsce (w kg/krowę/rok)

\begin{tabular}{|c|c|c|}
\hline Rok & $\begin{array}{c}\text { Średnia wydajność mleczna krów } \\
\text { ogólem }\end{array}$ & $\begin{array}{c}\text { Średnia wydajność mleczna krów } \\
\text { pozostających pod kontrolą } \\
\text { użytkowości }\end{array}$ \\
\hline 2000 & 3656 & 5379 \\
\hline 2001 & 3741 & 5597 \\
\hline 2002 & 3864 & 5712 \\
\hline 2003 & 3896 & 5851 \\
\hline 2004 & 3965 & 6152 \\
\hline 2005 & 4150 & 6508 \\
\hline 2006 & 4161 & 6664 \\
\hline 2007 & 4288 & 6688 \\
\hline 2008 & 4400 & 6817 \\
\hline 2009 & 4548 & 6935 \\
\hline 2010 & 4800 & 6980 \\
\hline 2011 & 5038 & 7135 \\
\hline 2012 & 5247 & 7396 \\
\hline 2013 & 5524 & 7441 \\
\hline 2014 & 5793 & 7582 \\
\hline
\end{tabular}

Źródlo: opracowanie na podstawie T. Piechowska, Stan obecny i perspektywy hodowli bydla mlecznego w Polsce, ,,Wiadomości Zootechniczne” 2015, t. LIII, nr 2, s. 36-45.

Podobne wnioski wynikają z porównań dotyczących efektów produkcyjnych uzyskiwanych w chowie trzody chlewnej. W tabeli 6.16 przedstawiono wyniki produkcyjne osiągane w chowie trzody chlewnej w Polsce i wybranych krajach UE-15. Wynika z nich, że polscy producenci osiągają wyraźnie słabsze rezultaty niż producenci z tych krajów.

Tabela 6.16. Średnie wyniki produkcyjne w chowie trzody chlewnej w wybranych krajach

\begin{tabular}{|l|c|c|c|c|c|}
\hline \multicolumn{1}{|c|}{ Wyszczególnienie } & Polska & Dania & Niemcy & Austria & UE-15 \\
\hline $\begin{array}{l}\text { Liczba tuczników sprzedanych/rok/lochę } \\
\text { (w sztukach) }\end{array}$ & 15,5 & 25,6 & 22,5 & 21,7 & 23,0 \\
\hline Liczba miotów/rok/lochę (w sztukach) & 1,83 & 2,25 & 2,30 & 2,27 & 2,28 \\
\hline $\begin{array}{l}\text { Zużycie paszy na przyrost kg masa ciała } \\
\text { od odsadzenia do sprzedaży (w kg) }\end{array}$ & 3,42 & 2,66 & 2,92 & 2,92 & 2,89 \\
\hline
\end{tabular}

Źródło: Z. Pejsak, „Przyczyny spadku pogłowia trzody chlewnej w Polsce w ostatnich latach”, materiaty konferencyjne pt. „Rozwój chowu i hodowli trzody chlewnej szansa dla gospodarstw towarowych w Polsce”, Warszawa, 14.12.2012 r. 
Niekorzystnie na tle krajów Unii Europejskiej wypada Polska również w zakresie liczby gospodarstw i przeciętnej ich wielkości obszarowej oraz wielkości stad zwierząt, które są mniej liczne niż w krajach Europy Zachodniej. To właśnie niska skala produkcji zwierzęcej w Polsce jest główną przeszkodą w wykorzystaniu postępu biologicznego ${ }^{275}$.

\subsection{Podsumowanie}

Produkcja żywności na świecie jest obecnie wystarczająca dla zapewnienia wyżywienia ludności. Przewidywany w perspektywie najbliższych trzydziestu lat wzrost liczby ludności o ponad dwa miliardy nieuchronnie prowadzi jednak do pytania, czy wystarczy żywności? Oceny takie są przedstawiane nie tylko w aspekcie wzrostu liczby ludzi, ale także w aspekcie wzrostu zamożności społeczeństw oraz zmniejszającej się liczby ludności wiejskiej i zajmującej się rolnictwem. W związku z tym żywność musi być coraz bardziej przetwarzana, konserwowana, transportowana na duże odległości i długoterminowo przechowywana. $\mathrm{W}$ tej sytuacji zarówno ubytki w trakcie przetwarzania, jak i straty w kolejnych etapach dystrybucji są nieuniknione. Skłonność bogatszych społeczeństw do luksusowej konsumpcji i stosowanie technik marketingowych zachęcających do kupowania prowadzi także do nasilania się zjawiska marnowania żywności.

Obserwowane zmiany dotyczące klimatu, w tym rozkładu opadów, temperatur, długości okresu wegetacji itp. powodują, że występujące i dostępne obecnie odmiany roślin i rasy zwierząt okazują się nie dość przystosowane do nowych warunków. Dodatkowo szybki postęp w technologii produkcji kreuje wymagania $\mathrm{w}$ innych sferach. Możliwości automatycznej obsługi, łatwość w mechanicznym przetwarzaniu stają się powodem poszukiwania takich rozwiązań, w których rośliny i zwierzęta są dostosowywane do ograniczeń ze strony techniki. Przykładem może być podatność owoców i warzyw na automatyczne sortowanie, łatwość omłotu zbóż, szybkość udoju czy budowa wymienia u krów. Ograniczenia wynikające $\mathrm{z}$ nieodpowiednich cech roślin i zwierząt mogą prowadzić do sytuacji, w której nie będzie możliwe, bez dodatkowych nakładów i strat, zastosowanie automatycznych linii sortujących, kombajnów czy automatów udojowych. Nie będzie można w pełni korzystać z osiągnięć w zakresie postępu w technice w rolnictwie.

\footnotetext{
${ }^{275}$ H. Runowski, Tendencje zmian w organizacji i ekonomice przedsiębiorstw rolnych - aspekty teoretyczne, „Zeszyty Naukowe SGGW w Warszawie. Ekonomika i Organizacja Gospodarki Żywnościowej” 2009, nr 75, s. 197-210; W. Ziętara, M. Adamski, Skala produkcji, efektywność $i$ konkurencyjność polskich gospodarstw wyspecjalizowanych w produkcji mleka, ,Zagadnienia Ekonomiki Rolnej” 2014, nr 1, s. 97-115.
} 
Postęp biologiczny, jako element szerzej rozumianego postępu w rolnictwie, umożliwia przełamywanie barier wynikających zarówno z istniejących i pojawiających się ograniczeń w środowisku naturalnym, jak i ograniczeń ze strony rozwijającej się, lecz wciąż niedoskonałej techniki. Przykładem takich ograniczeń mogą być: nasilenie występowania chorób, większa presja szkodników, dłuższe okresy bez opadów, wyższe temperatury w okresie wegetacji, a także ww. ograniczenia techniczne.

Rozwiązaniem części problemów może być kreowanie innowacji biologicznych w ramach hodowli roślin i zwierząt. Dobrym, a jednocześnie szeroko znanym przykładem osiągnięć w tym zakresie są gatunki i odmiany roślin modyfikowanych genetycznie. Uzyskano odmiany, które ze względu na odporność na szkodniki, tolerancję na herbicydy, mogą być uprawiane nawet w regionach z dużą presją szkodników lub, dzięki uproszczeniu technologii produkcji, na dużą skalę, przy relatywnie niskich nakładach. Im bardziej nowe odmiany i rasy przyczyniają się do usprawnienia produkcji, tym większy może to mieć wpływ na poziom kosztów i konkurencyjność produkcji. Warunkiem jest możliwość efektywnego wdrożenia danej nowości.

Postęp, w rozumieniu skutecznego wprowadzania nowości (innowacji), odgrywa coraz większą rolę w kreowaniu wzrostu w gospodarce, większą przy tym niż wzrost nakładów. W rolnictwie postęp jako taki dzielony jest na poszczególne formy. Umożliwia to lepszą ocenę ważności określonych form postępu w danym czasie. Wyróżnia się następujące rodzaje postępu: mechanizacyjny, chemizacyjny, biologiczny, technologiczny i organizacyjny. Są też inne jego klasyfikacje.

W rolnictwie w kolejnych okresach obserwowana była dominacja poszczególnych form postępu. Początkowo najsilniej na wzrost produktywności oddziaływał postęp mechanizacyjny, następnie chemizacyjny w zakresie wzrostu intensywności (nawożenie), chemizacyjny w zakresie substytucji nakładów (ochrona roślin, farmaceutyki), obecnie wskazuje się na dominację postępu biologicznego. Nie oznacza to, że te formy postępu, które nie dominują, tracą na znaczeniu. Wciąż ważny jest postęp mechanizacyjny, szczególnie gdy dotyczy substytuowania pracy ludzkiej lub tzw. rolnictwa precyzyjnego.

Wprowadzanie postępu w rolnictwie prowadzi do zwiększania efektywności ekonomicznej, społecznej lub środowiskowej produkcji. Z punktu widzenia ekonomicznego po upowszechnieniu danej innowacji następuje obniżka jednostkowych kosztów wytwarzania, wzrost wydajności jednostkowej, w tym z jednostki powierzchni. W warunkach mało elastycznego popytu na żywność pojawiająca się większa ilość produkcji prowadzi do obniżenia cen. W efekcie 
głównymi beneficjentami postępu stają się końcowi odbiorcy żywności - konsumenci. Producentom przypada niewielka część dodatkowych korzyści. Oprócz tego zwiększa się konkurencja na rynku produktów rolnych. W warunkach liberalizacji handlu międzynarodowego może to prowadzić do sytuacji, kiedy w danym kraju określona produkcja będzie nieopłacalna ze względu na to, że w innym kraju można dany produkt wytworzyć o tyle taniej, że nawet po dodaniu marży transportowej będzie on konkurencyjny. Szczególne znaczenie ma to w przypadku żywności nietrwałej, dla której uzyskano dłuższy okres trwałości, dzięki czemu może być dłużej transportowana i przechowywana.

Skuteczne wprowadzanie postępu napotyka wiele ograniczeń. Do najważniejszych można zaliczyć bariery środowiskowe, a następnie technologiczne. Niebagatelne znaczenie mają także ograniczenia budżetowe lub nieodpowiednia struktura rolnictwa, czy też zbyt mała skala produkcji. Przykładem ograniczeń dotyczących środowiska może być produkcja pszenicy i kukurydzy. W warunkach przeciętnej jakości gleb w Polsce nie uda się osiągnąć takiego poziomu plonów jak na czarnoziemach na Ukrainie, zakładając podobną technologię uprawy. Inaczej jest w produkcji zwierzęcej, gdzie najważniejszymi barierami są skala produkcji i wysoki koszt wdrażania postępu (nowych rozwiązań).

$\mathrm{O}$ znaczeniu postępu biologicznego i zapotrzebowaniu na innowacje w tym obszarze świadczy szybki rozwój uprawy roślin modyfikowanych genetycznie. W latach 1996-2016 powierzchnia uprawy tych roślin na świecie zwiększyła się stukrotnie z 1,7 do $185 \mathrm{mln}$ ha. Wynikało to z zapotrzebowania na odmiany o określonych cechach. Jako główne przyczyny wprowadzania roślin GMO do produkcji rolnicy wskazywali wyższe plonowanie, ograniczenie zużycia pestycydów i uproszczenie technologii produkcji. W części krajów odmiany GMO dominują w produkcji wybranych gatunków roślin (np. kukurydza, soja i bawełna w USA, soja w Brazylii i Argentynie).

W warunkach polskiego rolnictwa uzyskiwany jest znaczący postęp w hodowli roślin i zwierząt. Potencjał plonowania odmian zbóż dostępnych dla rolników w Polsce osiąga 75-85 dt/ha przy niższym poziomie intensywności, a przy wyższym poziomie intensywności nawet ponad $100 \mathrm{dt} / \mathrm{ha}$. Poziom wykorzystania potencjału plonowania odmian jest $\mathrm{w}$ polskim rolnictwie relatywnie niski. Wynosi on od 40\% dla żyta i owsa do 55-58\% dla takich gatunków, jak pszenica ozima i jęczmień ozimy. Oznacza to, że potencjał plonowania wykorzystywany jest w większym stopniu w produkcji gatunków intensywnych, które są zwykle uprawiane na lepszych glebach. W takich warunkach ograniczenia wynikające z luki środowiskowej (gorszej jakości stanowiska) mają mniejsze znaczenie, a istotną rolę mogą mieć ograniczenia w technologii, która podlega kontroli rolników. 
Mimo relatywnie niskiego poziomu wykorzystania potencjału plonowania odmian obserwowano stały wzrost plonów w produkcji rolniczej. Średnioroczny przyrost plonowania w produkcji w ostatnim dwudziestoleciu wynosił około $2 \%$ średnio dla wszystkich gatunków zbóż. Z dostępnych analiz wynika, że od 30 do $60 \%$ tego przyrostu, zależnie od gatunku i poziomu intensywności produkcji, było uzyskiwane dzięki wprowadzaniu postępu biologicznego w produkcji roślinnej. Dla gatunków, w których dominują odmiany hybrydowe, efekt ten mógł być w ujęciu długookresowym nawet wyższy.

Relatywnie niski wpływ postępu biologicznego na przyrost poziomu plonowania może wynikać także z niskiego wykorzystania nośników postępu biologicznego (kwalifikowanego materiału siewnego) w produkcji. W zależności od gatunku tylko od 10 do $20 \%$ materiału zużywanego do siewu stanowi materiał kwalifikowany. Wyższy udział obserwowany jest dla gatunków uprawianych intensywnie i dominujących w produkcji towarowej rolnictwa. Przy użyciu produkcji na potrzeby własne, czyli w przypadku niskiej towarowości gospodarstw, rola postępu biologicznego jest mała.

W produkcji zwierzęcej znaczące osiągnięcia, prowadzące zarówno do wzrostu produktywności, jak i wzrostu efektywności ekonomicznej produkcji, osiągnięto $\mathrm{w}$ produkcji bydła oraz drobiu. $\mathrm{W}$ okresie ostatnich dwudziestu lat nastąpiła prawie całkowita wymiana pogłowia ras tradycyjnych, o niskiej wydajności, na rasy cechujące się lepszymi cechami produkcyjnymi. Dotyczy to zarówno produkcji mleka, jak i produkcji żywca rzeźnego oraz drobiowego. Rasy przydatne do użytkowania wielostronnego zostały zastąpione rasami z przewagą cech sprzyjających wydajności mlecznej lub mięsnej. Wymiana pogłowia możliwa była dzięki osiągnięciom polskiej hodowli w zakresie udoskonalenia ras, a także dopływowi zwierząt $\mathrm{z}$ hodowli zagranicznych, co przyczyniło się do szybszego ulepszenia pogłowia.

Efektem postępu w zakresie produkcji mleka jest znaczny wzrost wydajności mlecznej krów. W latach 2000-2014 przeciętna wydajność mleczna krów wzrosła z prawie 3,7 tys. litrów do prawie 5,8 tys. litrów, czyli o ponad 58\%. Podobny przyrost, o 2,2 tys. litrów rocznie, uzyskano w stadach podlegających kontroli użytkowości. W 2014 roku wydajność mleczna wynosiła w nich prawie 7,6 tys. litrów, czyli o około 41\% więcej niż w 2000 roku. Trzeba pamiętać, że całościowy postęp w tym zakresie zależał nie tylko od czynników o charakterze biologicznym, ale także technicznym i technologicznym.

Postęp w gospodarce, w tym w rolnictwie, jest ważnym czynnikiem prowadzącym do zwiększania produktywności. Dla rolnictwa światowego w okresie po 2000 roku ustalono, że około $70 \%$ wzrostu produktywności można przypisać 
wprowadzaniu postępu, a tylko 30\% wynika ze zwiększania nakładów materialnych czynników produkcji. Dla Polski ustalono, że mimo łącznego spadku nakładów o 0,9\%, nastąpił wzrost produkcji o 0,6\%. Osiąganie wzrostu produkcji mimo spadku nakładów oznacza, że nastąpiła poprawa wykorzystania dostępnych zasobów przypisywana wprowadzaniu postępu we wszystkich jego formach, w tym substytucji nakładów (postęp technologiczny).

Możliwość kreowania dodatkowych długoterminowych przewag konkurencyjnych polskiego rolnictwa $\mathrm{w}$ związku $\mathrm{z}$ wprowadzaniem postępu jest ograniczona. Wynika to z liberalizacji dostępu do nowości. W poszczególnych krajach istnieje podobna możliwość unowocześniania rolnictwa i uzyskiwania dużych partii wysokiej jakości surowców rolniczych. W ujęciu krótko- i średnioterminowym możliwe jest wspieranie transferu postępu do rolnictwa w celu przyspieszenia jego modernizacji, a co za tym idzie, zapewnienie stabilnej wysokiej pozycji konkurencyjnej. Chłonność polskiego rolnictwa na postęp, w tym postęp biologiczny, zależy w dużym stopniu od jego struktur. Gospodarstwa o mniejszym obszarze i mniejszej sile ekonomicznej oraz o słabszych związkach rynkowych mają ograniczone możliwości wykorzystania w pełni szans wynikających z wdrażania postępu. 


\section{Zakończenie}

Postępujące procesy globalizacji, integracji i liberalizacji gospodarek, sprzyjające upowszechnianiu się paradygmatu otwartego rozwoju gospodarczego i internacjonalizacji działalności gospodarczej, wywołały zmianę charakteru, intensywności i zasięgu konkurencji, która nabrała wymiaru międzynarodowego, polegającego $\mathrm{z}$ jednej strony na konkurowaniu na rynkach międzynarodowych, a z drugiej - konieczności zmagania się z presją konkurencyjną ze strony podmiotów zagranicznych na rynkach regionalnych i krajowych. Ten międzynarodowy wymiar konkurencji sprawia, że podmioty uczestniczące w rynku i konkurujące o korzyści płynące $\mathrm{z}$ udziału $\mathrm{w}$ handlu międzynarodowym stają wobec nowych wyzwań, a warunki, w jakich funkcjonują, są coraz trudniejsze.

Analiza uwarunkowań makroekonomicznych, politycznych i społecznych konkurencyjności sektora żywnościowego w Polsce pozwoliła zidentyfikować czynniki zarówno o pozytywnym, jak i negatywnym wpływie na jego potencjał konkurencyjny, w kontekście wyzwań związanych z globalizacją i cyfryzacją gospodarki. W analizie uwzględniono czynniki społeczne o charakterze strukturalnym, czynniki makroekonomiczne i polityczne związane z funkcjonowaniem zarówno instytucji w państwie, jak i prowadzonymi przez państwo politykami, oraz czynniki społeczne na poziomie mikroekonomicznym związane ze stanem zasobów ludzkich i potencjałem kapitału ludzkiego w sektorze żywnościowym.

Z perspektywy konkurencyjności systemowej wynika, że na poziomie meta podstawową barierą wzmacniania potencjału konkurencyjnego sektora żywnościowego jest niski poziom kapitału społecznego i zaufania w Polsce. Widoczne deficyty $w$ tej dziedzinie nie sprzyjają zmianom oraz dyfuzji innowacji. Możliwie pełne wykorzystanie szans wynikających z rewolucji cyfrowej wymagałoby zwiększenia wysiłków na rzecz zacieśniania współpracy na poziomie lokalnym, koniecznej do tworzenia wspólnych platform i zasobów danych cyfrowych w sektorze. Sytuacja makroekonomiczna pozytywnie wpływała natomiast na konkurencyjność gospodarki żywnościowej w Polsce. Przyczyniały się do tego m.in.: stały realny wzrost PKB na mieszkańca, stabilna polityka monetarna i utrzymywanie dyscypliny w finansach publicznych. Obecne uwarunkowania makroekonomiczne nadal sprzyjają utrzymywaniu przewag cenowych polskiego sektora rolno-spożywczego. Można jednak spodziewać się, że przewagi te będą stopniowo zanikać w związku ze spodziewanym wzrostem kosztów pracy w Polsce. Uwarunkowania polityczne na poziomach makro i mezo związane z funkcjonowaniem instytucji i politykami prowadzonymi przez państwo miały zróżnicowany wpływ na konkurencyjność polskiej gospodarki żywnościowej. 
Negatywnie na konkurencyjność wpływała stosunkowo duża zmienność krajowego otoczenia regulacyjnego, pozytywne impulsy płynęły zaś ze strony regulacji przyjmowanych na szczeblu europejskim. $Z$ kolei polityki sektorowe nie zapewniały dostatecznego wsparcia dla badań, rozwoju i innowacji w sektorze. Zasoby ludzkie w sektorze żywnościowym także nie są dostosowane do wymogów epoki cyfrowej. Niski obecnie poziom kompetencji i wiedzy może zatem opóźniać cyfrową transformację w sektorze. Kluczowe dla poprawy perspektyw wzmacniania konkurencyjności sektora żywnościowego byłoby zwiększenie inwestycji w zakresie rozwoju wykorzystania zdobyczy rewolucji cyfrowej w praktyce życia społecznego i gospodarczego.

Sektor rolno-spożywczy stoi więc przed ogromnymi wyzwaniami wynikającymi z dostosowywania się do nowych uwarunkowań zewnętrznych związanych z rozwojem nowych technologii o potencjalnie dużym wpływie na kształtowanie przewag konkurencyjnych w przyszłości. Równocześnie stoi przed nowymi barierami wynikającymi z narastających nacjonalizmów i tendencji do dezintegracji na poziomie Unii Europejskiej. W obecnej sytuacji ewentualny kryzys instytucji europejskich może negatywnie oddziaływać na perspektywy rozwoju wspólnych polityk, a tym samym na perspektywy rozwoju polskiego sektora rolno-spożywczego. Istotne z punktu widzenia wzmacniania potencjału konkurencyjnego sektora byłoby więc nie tylko wypracowanie strategii cyfryzacji dedykowanej stricte temu sektorowi, ale również zaangażowanie w działania wzmacniające instytucje europejskie w tym obszarze.

Dotychczasowy bilans członkostwa Polski w Unii Europejskiej dla podmiotów polskiego sektora rolno-spożywczego, które zdecydowały się rozwijać zagraniczną wymianę handlową i aktywnie uczestniczyć w procesie internacjonalizacji, jest zdecydowanie korzystny. Świadczą o tym bardzo dobre wyniki polskiego handlu zagranicznego produktami rolno-spożywczymi, w tym przede wszystkim dynamicznie rosnący eksport i wysokie dodatnie saldo obrotów handlowych, a także wyraźna specjalizacja eksportowa sektora. W latach 2004-2016 nastąpił ponad czterokrotny wzrost eksportu oraz siedmioipółkrotny wzrost nadwyżki handlowej. Zwiększył się poziom koncentracji w handlu rolno-spożywczym zarówno pod względem geograficznym, jak i towarowym.

Analiza przewag komparatywnych w handlu rolno-spożywczym Polski, przeprowadzona na podstawie wskaźnika relatywnej przewagi RTA (uwzględniającego sytuację zarówno w zakresie eksportu, jak i importu), która umożliwia przybliżoną ocenę zdolności danego sektora do konkurowania w handlu międzynarodowym, a jednocześnie daje podstawę do oceny jego międzynarodowej pozycji konkurencyjnej, potwierdziła konkurencyjność polskich producentów żywności. W okresie członkostwa w UE Polska posiadała relatywne przewagi 
komparatywne w handlu rolno-spożywczym na rynku światowym, a także z głównymi partnerami handlowymi. Najwyższe przewagi, niemal w całym okresie, polscy producenci żywności odnotowywali na rynku państw UE-13, a najniższe - nieprzerwanie na rynku państw UE-15. Produkty, w handlu którymi Polska posiadała w 2016 roku przewagi komparatywne, stanowiły niespełna 3/4 obrotów handlowych polskiego sektora rolno-spożywczego na rynku światowym. Najogólniej rzecz biorąc, można stwierdzić, że podmioty polskiego sektora żywnościowego pozostawały konkurencyjne na rynku międzynarodowym.

Wysoka dynamika procesów zachodzących we współczesnej gospodarce powoduje, że próbując odpowiedzieć na pytanie, dlaczego jeden kraj czy sektor gospodarki odnosi większe sukcesy w handlu zagranicznym i jest bardziej konkurencyjny od drugiego, wciąż poszukujemy nowych metod objaśniających wymianę handlową i pozwalających oceniać konkurencyjność. Jedną z takich metod jest cenowo-jakościowa metoda badania konkurencyjności oparta na wskaźniku cen relatywnych w eksporcie RC, której zastosowanie pozwoliło stwierdzić, że w latach 2004-2016 Polska miała w eksporcie rolno-spożywczym do państw Unii Europejskiej cenowe przewagi konkurencyjne nad pozostałymi konkurentami. Oznacza to, że ceny oferowane przez polskich producentów żywności na rynkach tych państw były niższe niż ceny oferowane przez krajekonkurentów. Niższe ceny w porównaniu z konkurentami notowano przy tym w eksporcie do państw UE-13 niż do państw UE-15.

Podpisanie umów DCFTA z UE otwiera nowe możliwości dla polskich producentów produktów rolno-spożywczych oraz stwarza możliwości osiągania korzyści w związku z liberalizacją handlu dla obu stron. Umowy te mają jednak działanie długoterminowe, a ich pozytywny efekt jest uzależniony przede wszystkim od tego, czy kraje Partnerstwa Wschodniego rzeczywiście przyjmą i wdrożą zawarte $w$ tych umowach regulacje unijne. $Z$ całą pewnością większe znaczenie będzie miała umowa UE z Ukrainą, która z uwagi na bliskość geograficzną, więzi kulturowe, historyczne i społeczne jest ważnym partnerem handlowym Polski. Z perspektywy Polski zarówno Gruzja, jak i Mołdawia nie są bowiem znaczącymi partnerami handlowymi.

Wraz z postępującą globalizacją i liberalizacją światowego handlu żywnością zwiększa się znaczenie promocji produktów rolno-spożywczych na rynkach zagranicznych. Obecnie aktywna działalność promocyjna nie jest dodatkowym atutem producenta lokującego swoje produkty na rynku, jak uważano jeszcze kilkanaście lat temu, ale warunkiem koniecznym wejścia i utrzymania się na rynku. Podstawowym celem działań promocyjnych podejmowanych przez producentów żywności w UE, w tym w Polsce, staje się podnoszenie świadomo- 
ści konsumentów w zakresie jakości unijnych produktów rolno-spożywczych, ukierunkowane na wzmacnianie ich międzynarodowej pozycji konkurencyjnej.

Produkcja żywności na świecie jest obecnie wystarczająca dla zapewnienia wyżywienia ludności. W związku z przewidywanym wzrostem liczby ludności i zwiększaniem się zamożności społeczeństw, jak również zmniejszaniem się liczby ludności wiejskiej i zajmującej się rolnictwem, w perspektywie najbliższych trzydziestu lat poziom produkcji żywności może okazać się jednak niewystarczający. Z ogólnoświatowego bilansu zapotrzebowania na żywność wynika więc potrzeba wzrostu produkcji rolnej. Tymczasem obserwowane zmiany dotyczące klimatu powodują, że dostępne obecnie odmiany roślin i rasy zwierząt okazują się nie dość przystosowane do nowych warunków. Dodatkowo szybki postęp w technologii produkcji tworzy presję na poszukiwanie takich rozwiązań, w których rośliny i zwierzęta będą lepiej dostosowane do wymagań ze strony techniki.

Postęp biologiczny, jako element szerzej rozumianego postępu w rolnictwie, umożliwia przełamywanie barier wynikających zarówno z ograniczeń w środowisku naturalnym, jak i ograniczeń ze strony wciąż niedoskonałej techniki. Rozwiązaniem części problemów może być kreowanie innowacji biologicznych w ramach hodowli roślin i zwierząt. Dobrym, a jednocześnie powszechnie znanym przykładem osiągnięć w tym zakresie są gatunki i odmiany roślin modyfikowanych genetycznie. Im bardziej nowe odmiany i rasy przyczyniają się do usprawnienia produkcji, tym większy może to mieć wpływ na poziom kosztów i konkurencyjność produkcji. Warunkiem jest jednak efektywne wdrożenie tych nowości.

Możliwość kreowania dodatkowych długoterminowych przewag konkurencyjnych polskiego rolnictwa $\mathrm{w}$ związku $\mathrm{z}$ wprowadzaniem postępu jest ograniczona. W ujęciu krótko- i średnioterminowym możliwe jest jednak wspieranie transferu postępu do rolnictwa w celu przyspieszenia jego modernizacji, a w efekcie poprawa jego pozycji konkurencyjnej. Chłonność polskiego rolnictwa na postęp, w tym postęp biologiczny, zależy w dużej mierze od jego struktur. Gospodarstwa o mniejszym obszarze i mniejszej sile ekonomicznej oraz słabszych powiązaniach z rynkiem mają ograniczone możliwości korzystania z szans wynikających z wdrażania postępu.

Zaprezentowane ujęcie konkurencyjności polskich producentów żywności potwierdza, że jest to zjawisko bardzo złożone i wieloaspektowe. Pozwala ono tym samym na interdyscyplinarne łączenie badań nad konkurencyjnością, tj. czerpanie zarówno z teorii handlu zagranicznego, teorii wzrostu i rozwoju, jak i z perspektywy mikroekonomicznej, obecnej na przykład w teorii zarządzania. Rozważania w tym ujęciu będą kontynuowane w kolejnych latach. 


\section{Literatura}

Acemoglu D., Johnson S., Robinson J.A., Institutions as a fundamental cause of long-run growth, [w:] P. Aghion i S.N. Durlauf (red.), Handbook of Economic Growth 1, Elsevier 2005, s. 385-472.

Adamowicz M., Teoretyczne uwarunkowania rozwoju rolnictwa z uwzględnieniem procesów globalizacji i międzynarodowej integracji, „Roczniki Nauk Rolniczych. Seria G” 2008, t. 94, z. 2.

Adarov A., Havlik P., Benefits and Costs of DCFTA: Evaluation of the Impact on Georgia, Moldova and Ukraine, The Vienna Institute for International Economic Studies 2016.

Aiginger K., Europe's Position in Quality Competition, [w:] Competitiveness Report 2000, European Commission, Brussels 2000.

Aiginger K., The use of unit values to discriminate between price and quality competition, „Cambridge Journal of Economics” 1997, nr 21, s. 571-592.

Aiginger K., Unit values to signal the quality position of CEECs, [w:] Y. Wolfmayr (red.), The Competitiveness of Transition Countries, OECD Publishing, 1998, s. 93-121.

Alexandratos N., Bruinsma J., World agriculture towards 2030/2050: the 2012 revision, Rome FAO ESA Working paper, 2012, nr 12-03.

Altkorn J. (red.), Leksykon marketingu, PWE, Warszawa 1998.

Altkorn J. (red.), Podstawy marketingu, Instytut Marketingu, Kraków 2000.

Ambroziak Ł., Kierunki specjalizacji w handlu zagranicznym Polski z Unia Europejska, [w:] E. Kaliszuk i K. Marczewski (red.), Wpływ członkostwa w Unii Europejskiej na stosunki gospodarcze Polski z zagranica, IBRKK, Warszawa 2009.

Ambroziak Ł., Konkurencyjność cenowo-jakościowa polskich producentów żywności na rynku niemieckim, „Zeszyty Naukowe SGGW w Warszawie. Problemy Rolnictwa Światowego” 2016, nr 16(31), z. 1, s. 7-24.

Ambroziak Ł., Price and quality competition strategies of Polish agri-food products exporters, [w:] T. Löster i T. Pavelka (red.), The 7th International Days of Statistics and Economics. Conference Proceedings, September 19-21, 2013, Prague, Libuše Macáková, Melandrium, 2013, s. 22-32.

Ambroziak Ł., Wpływ umowy o wolnym handlu Unia Europejska-Ukraina na polski import rolno-spożywczy z Ukrainy, ,Studia i Prace Wydziału Nauk Ekonomicznych i Zarządzania Uniwersytetu Szczecińskiego" 2017, nr 49/2, s. 9-22.

Ambroziak Ł., Błaszczuk-Zawiła M., Czy unijne preferencje handlowe maja znaczenie? Przypadek polsko-ukraińskiej wymiany handlowej w latach 2010-2015, „Zeszyty Naukowe Uczelni Vistula" 2016, seria: Ekonomia XI, nr 47(2), s. 19-33.

Ambroziak Ł., Bułkowska M., Całościowe Gospodarcze i Handlowe Porozumienie z Kanada (CETA) oraz Transatlantyckie Partnerstwo $w$ dziedzinie Handlu i Inwestycji (TTIP) a konkurencyjność polskich producentów żywności, [w:] I. Szczepaniak (red.), Konkurencyjność polskich producentów żywności i jej determinanty (1), seria „Monografie Programu Wieloletniego 2015-2019”, nr 11, IERiGŻ-PIB, Warszawa 2015, s. 88-113.

Ambroziak Ł., Szczepaniak I., Jakościowo-cenowe wskaźniki konkurencyjności w handlu produktami rolno-spożywczymi Polski, [w:] I. Szczepaniak (red.), Monitoring i ocena konkurencyjności polskich producentów żywności (2), seria „Program Wieloletni 2011-2014”, nr 40, IERiGŻ-PIB, Warszawa 2012, s. 71-90. 
Ambroziak Ł., Szczepaniak I., Monitoring i ocena konkurencyjności polskich producentów żywności (4). Pozycja konkurencyjna, seria „Pogram Wieloletni 2011-2014”, nr 74, IERiGŻ-PIB, Warszawa 2013.

Ambroziak Ł., Szczepaniak I., Ryzyko kursowe a handel zagraniczny produktami rolno-spożywczymi Polski, [w:] J. Góral i M. Wigier (red.), Ryzyko w gospodarce żywnościowejteoria i praktyka, seria „Monografie Programu Wieloletniego 2015-2019”, nr 48, IERiGŻ-PIB, Warszawa 2017, s. 89-105.

Ambroziak Ł., Szczepaniak I., Skutki rosyjskiego embarga na import produktów rolno-spożywczych, „Przemysł Spożywczy” 2014, nr 9, s. 2-8.

Ambroziak Ł., Szczepaniak I., Wskaźnikowa ocena konkurencyjności handlu produktami rolno-spożywczymi, [w:] I. Szczepaniak (red.), Monitoring i ocena konkurencyjności polskich producentów żywności (1), seria „Program Wieloletni 2011-2014”, nr 25, IERiGŻ-PIB, Warszawa 2011, s. 45-65.

Antczak S. (red.), Marketing. Wybrane problemy, Akademia Obrony Narodowej, Warszawa 2016.

Atluri V., Dietz M., Henke N., Competing in a world of sectors without borders, McKinsey Quarterly, July 2017.

Attitudes towards the impact of digitisation and automation on daily life, Special Eurobarometer 460, May 2017.

Balassa B., Trade Liberalization and Revealed Comparative Advantage, The Manchester School, vol. 33, 1965, s. 99-123.

Baza danych Banku Światowego: http://databank.worldbank.org/.

Baza danych Eurostatu: http://ec.europa.eu/eurostat/data/database.

Baza danych GUS: https://stat.gov.pl/wskazniki-makroekonomiczne/.

Baza danych Międzynarodowego Funduszu Walutowego: http://www.imf.org/en/data.

Baza danych OECD: https://data.oecd.org.

Baza danych WITS-Comtrade: https://wits.worldbank.org/.

Bennett P.D., Dictionary of Marketing Terms, American Marketing Association, Chicago 1995.

Berthou A., Emlinger Ch., The Trade Unit Values Database, CEPII Working Paper, nr 2011-10.

Bossak J.W., Konkurencyjność gospodarki Polski a proces integracji europejskiej i rozwoju gospodarki opartej na wiedzy, [w:] T. Michalski i K. Piech (red.), Konkurencyjność Polski w procesie pogtębiania integracji europejskiej i budowy gospodarki opartej na wiedzy, Oficyna Wydawnicza SGH, Warszawa 2008.

Brady M., Kellermann K., Sahrbacher C., Jelinek L., Impacts of decoupled agricultural support on farm structure, biodiversity and landscape mosaic: some EU results, ,Journal of Agricultural Economics" 2009, t. 60, nr 3, s. 563-585.

Brookes G., Barfoot P., GM crops: global socio-economic and environmental impacts 1996-2015, PG Economics Ltd, Dorchester, UK 2017.

Brynjolfsson E., McAfee A., The second machine age: Work, progress, and prosperity in a time of brilliant technologies, WW Norton \& Company, 2014.

Budnikowski A., Ekonomia międzynarodowa, Polskie Wydawnictwo Ekonomiczne, Warszawa 2017. 
Budnikowski A., Międzynarodowe stosunki gospodarcze, Polskie Wydawnictwo Ekonomiczne, Warszawa 2003.

Bułkowska M., Umowy o wolnym handlu UE z Korea Poludniowa, Singapurem i Wietnamem, [w:] I. Szczepaniak (red.), Konkurencyjność polskich producentów żywności i jej determinanty (2), seria „Monografie Programu Wieloletniego 2015-2019”, nr 38, IERiGŻ-PIB, Warszawa 2016, s. $122-145$.

Burzyński W., Analiza konkurencyjności polskiego eksportu do Unii Europejskiej przeprowadzona metoda jakościowo-cenowa, [w:] J. Kotyński (red.), Korzyści i koszty członkostwa Polski w Unii Europejskiej, t. I, IKCHZ, Warszawa 2000.

Burzyński W., Jasiński L., Analiza poziomu cen osiaganego przez eksporterów polskich na rynku niemieckim w latach 1992-1994, [w:] Polska polityka handlu zagranicznego 1995-1996, IKCHZ, Warszawa 1996.

Burzyński W., Marczewski K., Wojnar J., Analiza cen osiaganych przez eksporterów polskich i konkurentów z krajów Unii Europejskiej na rynku niemieckim w latach 1992-1995, [w:] Zagraniczna polityka gospodarcza Polski 1996-1997, IKCHZ, Warszawa 1997.

Castells M., The rise of the network society: The information age: Economy, society, and culture, t. 1, Wiley \& Blackwell, 2011.

Chechelski P., Korporacje transnarodowe $w$ przemyśle spożywczym $w$ Polsce, Prezentacja z seminarium IERiGŻ-PIB, Warszawa, 6.10.2017.

Commission staff working document accompanying the document "Monitoring the application of European Union law 2016 Annual Report” (Part I: Policy areas, Part II: Member States), Brussels, 6.7.2017.

Cukier K., Mayer-Schoenberger V., The rise of big data: How it's changing the way we think about the world, „Foreign Affairs” 2013, vol. 92(3).

Cyfrowa Polska. Szansa na technologiczny skok do globalnej pierwszej ligi gospodarczej, Raport McKinsey\&Company we współpracy z Forbsem, 2016.

Czyżewski A., Poczta A., Wawrzyniak Ł., Interesy europejskiego rolnictwa w świetle globalnych uwarunkowań polityki gospodarczej, „Ekonomista” 2006, nr 3, s. 347-369.

Day-Rubenstein K., Heisey P., Crop Genetic Resources, [w:] K. Wiebe i N. Gollehon (red.), Agricultural Resources and Environmental Indicators, 2006 Edition, Economic Information Bulletin 16, USDA, Washington, D.C., July 2006.

Day-Rubenstein K., Heisey P., Shoemaker R., Sullivan J., Friosvold G., Crop Genetic resources. An Economic Appraisal, Economic Information Bulletin 2, USDA, Washington, D.C. 2005.

Dietl J., Marketing, PWE, Warszawa 1985.

Digital Scoreboard - Data \& Indicators: http://digital-agenda-data.eu.

Domagalska-Grędys M., Kontekst innowacji w grupach producentów rolnych, „Wieś i Rolnictwo" 2016, nr 1(170).

Drożdż J., Stan przewag cenowych na rynku wybranych produktów przetwórstwa spożywczego, [w:] I. Szczepaniak (red.), Monitoring i ocena konkurencyjności polskich producentów żywności (3). Potencjał konkurencyjny - wybrane elementy, seria „Program Wieloletni 2011-2014”, nr 73, IERiGŻ-PIB, Warszawa 2013, s. 24-41.

Drożdż J., Mroczek R., Tereszczuk M., Rozwój przemystu spożywczego w Polsce i innych krajach Unii Europejskiej, [w:] R. Mroczek (red.), Przemiany strukturalne przemystu spożyw- 
czego w Polsce i UE na tle wybranych elementów otoczenia zewnętrznego, seria „Monografie Programu Wieloletniego 2015-2019”, nr 12, IERiGŻ-PIB, Warszawa 2015, s. 89-105.

Duchnowska E., Konkurencyjność cenowo-jakościowa polskiego handlu zagranicznego, [w:] K. Marczewski (red.), Ceny w handlu zagranicznym Polski. Aspekty makro- i mikroekonomiczne, Dom Wydawniczy ELIPSA, Warszawa 2014.

Dulleck U., Foster-McGregor N., Stehrer R., Wörz J., Dimensions of Quality Upgrading in CEECs, wiiw Working Paper, 2004, nr 29, Wien.

Edelman Trust Barometer 2016, https://www.edelman.com/post/trust-food-beverage-five-steprecipe-success/.

Esser K., Hillebrand W., Messner D., Meyer-Stamer J., Systemic competitiveness: new governance patterns for industrial development, GDI/Frank Cass, London 1996.

Eurostat, Newsrelease Euroindicators, 139/2017 - 15 September 2017.

Export and Import Price Index Manual. Theory and Practice, IMF, 2009.

Fernandez-Cornejo J., Wechsler S., Livingston M., Mitchell L., Genetically Engineered Crops in the United States, „Economic Research Report” 2014, nr 162, USDA, Economic Research Service, Washington, D.C.

Figiel S. (red.), Wybrane aspekty innowacyjności w sektorze rolno-spożywczym, seria „Monografie Programu Wieloletniego 2015-2019”, nr 10, IERiGŻ-PIB, Warszawa 2015.

Firlej K., Wzrost konkurencyjności przedsiębiorstw przemysłu spożywczego poprzez doskonalenie działań w obszarze zarzadzania wiedza, [w:] I. Szczepaniak (red.), Monitoring i ocena konkurencyjności polskich producentów żywności (3). Potencjat konkurencyjny - wybrane elementy, seria „Program Wieloletni 2011-2014”, nr 73, IERiGŻ-PIB, Warszawa 2013, s. 101-112.

Firlej K., Kowalska A., Piwowar A., Competitiveness and innovation of the Polish food industry, „Agricultural Economics” 2017, nr 63(11), s. 502-509.

Firlej K., Żmija D., Transfer wiedzy i dyfuzja innowacji jako źródło konkurencyjności przedsiębiorstw przemystu spożywczego w Polsce, Fundacja Uniwersytetu Ekonomicznego w Krakowie, Kraków 2014.

Frey C.B., Osborne M.A., The future of employment: how susceptible are jobs to computerisation?, „Technological Forecasting and Social Change” 2017, t. 114, nr C, s. 254-280.

Fuglie K.O., Rada N.E., Resources, Policies, and Agricultural Productivity in Sub-Saharan Africa, „Economic Research Report” 2013, nr 145, USDA, Economic Research Service, Washington, D.C.

Gavrilescu C., Voicilaş D.-M., Changes in the Romanian agrifood trade competitiveness in the post-accession period, „Management Theory and Studies for Rural Business and Infrastructure Development" 2014, vol. 36, nr 4, s. 823-834.

Global Status of Commercialized Biotech/GM Crops: 2016, ISAAA Brief 52, Ithaca, NY 2016.

Goenaga M., Radtke P., Speicher K., Westinner R., Ops 4.0: Fueling the next 20 percent productivity rise with digital analytics, April 2017, https://www.mckinsey.com/businessfunctions/operations/our-insights/ops-4-0-fueling-the-next-20-percent-productivity-rise-withdigital-analytics.

Gołębiewska B., Organizacyjno-ekonomiczne skutki zróżnicowania powiązá́ gospodarstw rolniczych z otoczeniem, Wydawnictwo SGGW, Warszawa 2010. 
Gotowość do wspótpracy, Komunikat z badań CBOS, nr 22, Warszawa, luty 2016.

Górska-Warsewicz H., Świątkowska M., Krajewski K., Marketing żywności, Wydawnictwo JAK, Warszawa 2013.

Greenaway D., Hine R., Milner C., Country specific factors and the pattern of horizontal and vertical intra-industry trade in the United Kingdom, „Weltwirtschaftliches Archiv” 1994, nr 130(1), s. 77-100.

Guzek M., Międzynarodowe stosunki gospodarcze. Zarys teorii i praktyki handlowej, Wydawnictwo Wyższej Szkoły Bankowej w Poznaniu, Poznań 2004.

Hartigan J.C., The U.S. tariff and comparative advantage: A survey of method, „Weltwirtschaftliches Archiv" 1981, vol. 117(1), s. 65-109.

Heady E., Ekonomika produkcji rolniczej, PWRiL, Warszawa 1967.

Heijman W., Krzyżanowska Z., Gędek S., Kowalski Z., Ekonomika rolnictwa. Zarys teorii, Wydawnictwo Fundacja „Rozwój SGGW”, Warszawa 1997.

Henke R., Benos T., De Filippis F., Giua M., Pierangeli F., Pupo D'Andrea M.R., The New Common Agricultural Policy: How do Member States Respond to Flexibility?, „Journal of Common Market Studies" 2017, s. 1-17.

Herausforderungen für die Landwirtschaft, Herausgeber Bayer AG, Communications and Public Affairs, Leverkusen 2015.

Herer W., Procesy wzrostu w rolnictwie, PWE, Warszawa 1970.

http://ec.europa.eu/agriculture/quality/door/list.html?\&filterReset=true.

http://unctad.org/en/PublicationsLibrary/wto2016_en.pdf.

http://www.arr.gov.pl/mleko-w-szkole.

https://ec.europa.eu/neighbourhood-enlargement/neighbourhood/eastern-partnership_en.

https://ec.europa.eu/poland/news/170901_ue_ukraine_pl.

https://www.kws.pl/aw/Burak-cukrowy/Hodowla/Metody-hodowli/ erbh/.

Informacja o rozmiarach i kierunkach czasowej emigracji z Polski w latach 2004-2016, Notatka informacyjna $\mathrm{z}$ dn. 16.10.2017 r., GUS.

Jambor A., Babu S., Competitiveness of global agriculture: Policy lessons for food security, Springer International Publishing Switzerland, 2016.

Janecki J., Pomiar i ocena stabilności makroekonomicznej w Polsce, „Acta Universitas Lodzensis. Folia Oeconomica" 2017, t. 2, nr 328.

Jansen R., Calculation of external trade indices based on unit values - training module, UN DESA, Statistics Division, 2009.

Jigl T., Effizienzsteigerung in der Milchviehhaltung durch optimierte Fütterung, Landwirtschaftliches Zentrum für Viehhaltung, Grünlandwirtschaft, Milchwirtschaft, Wild, Fischerei Baden-Württemberg, Aulendorf.

Jorgenson D., Morris S., The Economics of productivity, Edward Elgar Publishing Limited, Cheltenham 2009.

Kall J., Reklama, PWE, Warszawa 1995. 
Kawecka-Wyrzykowska E., Wsparcie finansowe w ramach Wspólnej Polityki Rolnej dla Polski w latach 2014-2020: ile na poprawę dochodów rolniczych i na wzmacnianie konkurencyjności rolnictwa?, [w:] I. Szczepaniak (red.), Konkurencyjność polskich producentów żywności i jej determinanty (1), seria „Monografie Programu Wieloletniego 2015-2019”, nr 11, IERiGŻ-PIB, Warszawa 2015, s. 67-87.

Kiełbasa B., Puchała J., Innowacyjność młodych rolników i ich postawy wobec zmian na przykładzie gospodarstw rolnych położonych $w$ regionie rozdrobnionego rolnictwa, ,Roczniki Naukowe Stowarzyszenia Ekonomistów Rolnictwa i Agrobiznesu” 2015, t. XVII, z. 1, s. 107-111.

Kierul Z., Majewski E., Postęp techniczny w gospodarstwie rolniczym, PWRiL, Warszawa 1991.

Klepacki B., Technologia produkcji a gospodarstwo rolnicze (ujęcie teoretyczne), [w:] F. Maniecki (red.), Postęp techniczny a organizacja gospodarstw rolniczych, Wydawnictwo SGGW, Warszawa 1997, s. 34-50.

Kołodko G.W., Koźmiński A.K., Nowy pragmatyzm kontra nowy nacjonalizm, Prószyński i S-ka, Warszawa 2017.

Kotler P., Marketing, Wydawnictwo Rebis, Warszawa 2005.

Kowalski A., Rolnictwo wobec wyzwań globalizacji, [w:] I. Szczepaniak i K. Firlej (red.), Przemyst spożywczy - makrootoczenie, inwestycje, ekspansja zagraniczna, Wydawnictwo Fundacja Uniwersytetu Ekonomicznego w Krakowie, IERiGŻ-PIB, Kraków-Warszawa 2015, s. 11-26.

Krasowicz S., Możliwości zwiększenia produkcji zbóż w Polsce, [w:] Czy Polsce grozi kryzys zbożowy, Wydawnictwo Wieś Jutra, Warszawa 2007, s. 66-78.

Krugman P.R., Obstfeld M., Ekonomia międzynarodowa. Teoria i praktyka, t. 1, Wydawnictwo Naukowe PWN, Warszawa 2007.

Krzymuski J., Postęp biologiczny w rolnictwie, [w:] A. Woś (red.), Encyklopedia Agrobiznesu, Fundacja Innowacja, Warszawa 1998, s. 581-585.

Latruffe L., Competitiveness, Productivity and Efficiency in the Agricultural and Agri-Food Sectors, „OECD Food, Agriculture and Fisheries Working Papers”, OECD Publishing 2010, nr 30 .

Legatum Prosperity Index 2016, http://www.prosperity.com.

Macron E., Initiative for Europe. A sovereign, united, democratic Europe, 26 September 2017, http://www.elysee.fr/assets/Initiative-for-Europe-a-sovereign-united-democratic-EuropeEmmanuel-Macron.pdf.

Majchrzycki D., Rynek kwalifikowanego materiatu siewnego pszenicy ozimej w Polsce, „Roczniki Naukowe Stowarzyszenia Ekonomistów Rolnictwa i Agrobiznesu” 2015, t. XVII, z. 3, s. 254-259.

Makki S., Tweeten L., Thraen C., Investing in research and education versus commodity programs: Implications for agricultural productivity, „Journal of Productivity Analysis” 1999, t. 12 , s. 77-94.

Manyika J., Lund S., Bughin J., Woetzel J.R., Stamenov K., Dhingra D., Digital globalization: The new era of global flows, McKinsey Global Institute, 2016.

Mańkowski D., Postęp biologiczny w hodowli, nasiennictwie i produkcji ziemniaka w Polsce. Część I. Przeglad ilościowych metod oceny postępu hodowlanego i odmianowego, Biuletyn Instytutu Hodowli i Aklimatyzacji Roślin, nr 251, Radzików 2009.

Marciniak S., Innowacje i rozwój gospodarczy, Ośrodek Nauk Społecznych PW, Warszawa 1997. 
Marciniak S. (red.), Makro- i mikroekonomia. Podstawowe problemy, Wydawnictwo Naukowe PWN, Warszawa 2005.

Martin A., Mercurio B., Doha dead and buried in Nairobi: lessons for the WTO, „Journal of International Trade Law and Policy" 2017, t. 16, nr 1, s. 49-66.

Messner D., The Network Society: Economic Development and International Competitiveness as Problems of Social Governance, Routledge, 2013.

Meyer-Stamer J., Systemic Competitiveness, http://www.meyer-stamer.de/systemic.html.

Michalewski T., Umowy o stowarzyszeniu z UE w ramach partnerstwa wschodniego - wybrane zagadnienia, [w:] M. Sadowski (red.), Z badań nad prawem, administracją i myśla polityczna, Uniwersytet Wrocławski, 2015.

Michalski E., Marketing. Podręcznik akademicki, Wydawnictwo Naukowe PWN, Warszawa 2003.

Ministerstwo Rozwoju, Plan na rzecz Odpowiedzialnego Rozwoju, Warszawa 2016.

Misala J., Historia rozwoju teorii i polityki konkurencyjności międzynarodowej, Wydawnictwo Szkoły Głównej Handlowej, Warszawa 2009.

Misala J., Międzynarodowa konkurencyjność gospodarki narodowej, Polskie Wydawnictwo Ekonomiczne, Warszawa 2011.

Misala J., Międzynarodowa zdolność konkurencyjna i międzynarodowa konkurencyjność gospodarki narodowej, Politechnika Radomska, Radom 2007.

Murawski M.P., Znaczenie promocji w działalności marketingowej przedsiębiorstwa, Wydawnictwo Promotor, Warszawa 2010.

Nalborczyk E., Postęp biologiczny a rozwój rolnictwa w końcu XX i początkach XXI stulecia, Agricola 33 - suplement, Wydawnictwo SGGW, Warszawa 1997.

Narodowy Bank Polski, Szybki Monitoring NBP. Analiza sytuacji sektora przedsiębiorstw, nr 04/17, Warszawa, październik 2017.

Nielsen J., Price-quality competition in the exports of the Central and Eastern European Countries, „Intereconomics” 2000, nr 35(2), s. 94-101.

Nordhaus W., Innowacje, wzrost $i$ dobrobyt. Postęp techniczny w ujęciu teoretycznym, PWN, Warszawa 1976.

Nowacki R. i Strużycki M. (red.), Reklama w procesach konkurencji, Wydawnictwo Difin SA, Warszawa 2011.

Nowak A., Gąsior R., Integracja pozioma producentów rolnych-możliwości i bariery, „Annales Universitatis Mariae Curie-Skłodowska", sectio H - Oeconomia 2017, t. 51 , nr 1.

Ndlovu T., Mariussen A., From Competitive Agility to Competitive Leapfrogging: Responding to the Fast Pace of Change, [w:] L.M. Carmo Farinha, J.J.M. Ferreira, H. Lawton Smith i S. Bagchi-Sen (red.), Handbook of Research on Global Competitive Advantage through Innovation and Entrepreneurship, Information Science Reference, IGI Global, 2015.

Nosecka B., Dybowski G., Globalne megatrendy a wzrost gospodarczy i rozwój oparty na wiedzy - sektor żywnościowy, seria „Monografie Programu Wieloletniego 2015-2019”, nr 17, IERiGŻ-PIB, Warszawa 2015.

Olczyk M., Konkurencyjność. Teoria i praktyka, Wydawnictwa Fachowe CeDeWu.PL, Warszawa 2008. 
Olson M., Sarna N., Swamy A.V., Governance and growth: A simple hypothesis explaining cross-country differences in productivity growth, ,Public Choice” 2000, t. 102, nr 3-4, s. 341-364.

Pawlak K., Poczta W., Międzynarodowy handel rolny, Polskie Wydawnictwo Ekonomiczne, Warszawa 2011.

Pejsak Z., „Przyczyny spadku pogłowia trzody chlewnej w Polsce w ostatnich latach”, materiały konferencyjne pt. „Rozwój chowu i hodowli trzody chlewnej szansą dla gospodarstw towarowych w Polsce", Warszawa, 14.12.2012 r.

Peneder M., Competitiveness and industrial policy: from rationalities of failure towards the ability to evolve, „Cambridge Journal of Economics” 2017, t. 41, nr 3, s. 829-858.

Piechowska T., Stan obecny i perspektywy hodowli bydta mlecznego w Polsce, „Wiadomości Zootechniczne" 2015, t. LIII, nr 2, s. 36-45.

Piotrowski J., Wpływ umowy o wolnym handlu Unii Europejskiej z Ukraina na import polskiwstępna ocena, „Unia Europejska.pl” 2016, nr 6, s. 27-38.

Porter M.E., Clusters and the new economics of competition, Boston: Harvard Business Review, 1998, t. 76, nr 6.

Porter M.E., Heppelmann J.E., How smart, connected products are transforming competition, „Harvard Business Review” 2014, vol. 92(11), s. 64-88.

Prus P., Czynniki hamujace chęć organizowania się rolników w grupy producentów rolnych, [w:] S. Zawisza (red.), Perspektywy rozwoju grup producentów rolnych - szanse i zagrożenia, Wydawnictwa Uczelniane Uniwersytetu Technologiczno-Przyrodniczego, Bydgoszcz 2010.

Prus P., Marcysiak T., Goszka W., Wielewska I., Działalność ośrodków doradztwa rolniczego $w$ procesie integracji poziomej $w$ rolnictwie $w$ opinii członków grup producentów rolnych, „Roczniki Naukowe Stowarzyszenia Ekonomistów Rolnictwa i Agrobiznesu” 2014, t. XVI, z. 3, s. 242-246.

Pugel T.A., International Economics, McGraw-Hill, International Edition, 2012.

Rembisz W., Identyfikacja procesów wzrostowych w sektorze rolno-spożywczym, seria „Monografie Programu Wieloletniego 2015-2019”, nr 22.1, IERiGŻ-PIB, Warszawa 2015.

„Rocznik Statystyczny Przemysłu 2016”, GUS, Warszawa 2016.

Rodrik D., Populism and the Economics of Globalization, „National Bureau of Economic Research" 2017, nr 23559.

Rodrik D., Subramanian A., Trebbi F., Institutions rule: the primacy of institutions over geography and integration in economic development, „Journal of Economic Growth” 2004, t. 9, nr 2, s. 131-165.

Rojewski M., Rychlik T., Stańko S., Czynniki ksztaltujące poziom produkcji i dochodów w rolnictwie, PWRiL, Warszawa 1987.

Rozporządzenie Parlamentu Europejskiego i Rady (UE) nr 1305/2013 z dnia 17 grudnia 2013 r. w sprawie wsparcia rozwoju obszarów wiejskich przez Europejski Fundusz Rolny na rzecz Rozwoju Obszarów Wiejskich (EFRROW) i uchylające rozporządzenie Rady (WE) nr 1698/2005, z późn. zm., Dz. Urz. UE L 347/487 z 20.12.2013.

Rozporządzenie Parlamentu Europejskiego i Rady (UE) nr 374/2014 z dnia 16 kwietnia 2014 r. w sprawie obniżenia lub zniesienia ceł na towary pochodzące z Ukrainy, Dz. Urz. UE L 118 z 22.04.2014. 
Rozporządzenie Parlamentu Europejskiego i Rady (UE) nr 978/2012 z dnia 25 października 2012 r. wprowadzające ogólny system preferencji taryfowych; http://eur-lex.europa.eu/legalcontent/PL/TXT/HTML/?uri=CELEX:02012R0978-20160101 \&qid=1455871043509\&from=PL.

Rozporządzenie Parlamentu Europejskiego i Rady (UE) nr 1144/2014 z dnia 22 października 2014 r. w sprawie działań informacyjnych i promocyjnych dotyczących produktów rolnych wdrażanych na rynku wewnętrznym i w państwach trzecich oraz uchylające rozporządzenie Rady (WE) nr 3/2008, Dz. Urz. UE L 317/56 z 4.11.2014.

Rozporządzenie Rady (WE) nr 1698/2005 z dnia 20 września 2005 roku w sprawie wsparcia rozwoju obszarów wiejskich przez Europejski Fundusz Rolny na rzecz Rozwoju Obszarów Wiejskich (EFRROW) z późn. zm., Dz. Urz. UE L 277/1 z 21.10.2005.

Runowski H., Koncentracja produkcji zwierzęcej, Wydawnictwo Fundacja „Rozwój SGGW”, Warszawa 1994.

Runowski H., Postęp biologiczny w rolnictwie, Wydawnictwo SGGW, Warszawa 1997.

Runowski H., Poszukiwanie równowagi ekonomiczno-ekologicznej i etycznej w produkcji mleka, „Roczniki Nauk Rolniczych. Seria G” 2007, t. 93, z. 2, s. 13-26.

Runowski H., Tendencje zmian w organizacji i ekonomice przedsiębiorstw rolnych - aspekty teoretyczne, „Zeszyty Naukowe SGGW w Warszawie. Ekonomika i Organizacja Gospodarki Żywnościowej” 2009, nr 75, s. 197-210.

Samuelson P., Nordhaus W., Ekonomia, PWN, Warszawa 2008.

Scott J., The future of agricultural trade governance in the World Trade Organization, „International Affairs" 2017, t. 93, nr 5, s. 1167-1184.

Shaping the future of work in Europe's digital front-runners, McKinsey Global Institute, October 2017.

Siggel E., International Competitiveness and Comparative Advantage: A Survey and a Proposal for Measurement, „, Journal of Industry, Competitiveness and Trade” 2006, nr 6.

Sikorska A. (red.), Kierunki przeobrażeń strukturalnych oraz uwarunkowania rozwoju rolnictwa i obszarów wiejskich, seria „Monografie Programu Wieloletniego 2015-2019”, nr 18, IERiGŻ-PIB, Warszawa 2015.

Single Market Scoreboard, Performance by Member State - Poland, http://ec.europa.eu/internal_ market/scoreboard/performance_by_member_state/poland/index_en.htm\#maincontentSec2.

Smid V., Encyklopedia promocji i reklamy, Wydawnictwo PSB, Kraków 2001.

Spoleczeństwo informacyjne $w$ Polsce. Wyniki badań statystycznych z lat 2012-2016, GUS, Warszawa 2016.

Sprawozdanie z działalności Agencji Rynku Rolnego w 2012 (2015 i 2016) roku, Warszawa 2013 (2016 i 2017).

Stankiewicz D., Rola postęu biologicznego w rolniczej produkcji roślinnej, Informacja nr 672, Sejm RP, Warszawa 1999.

Stiglitz J.E., The causes and consequences of the dependence of quality price, „The Journal of Economic Literature" 1987, nr 25, s. 1-48.

System Monitorowania Rozwoju Strateg: http://strateg.stat.gov.pl.

Szczepaniak I., Ceny żywności w Polsce i Unii Europejskiej w 2016 r., „Przemysł Spożywczy” 2017, nr 10, s. 2-6. 
Szczepaniak I., Jakościowo-cenowe strategie konkurencji w polskim handlu produktami rolno-spożywczymi, [w:] I. Szczepaniak (red.), Monitoring i ocena konkurencyjności polskich producentów żywności (5). Synteza, seria „Program Wieloletni 2011-2014”, nr 115, IERiGŻ-PIB, Warszawa 2014, s. 67-81.

Szczepaniak I., Konkurencyjność polskiego przemystu spożywczego na rynku krajowym i międzynarodowym - wybrane elementy, „Roczniki Naukowe Stowarzyszenia Ekonomistów Rolnictwa i Agrobiznesu" 2014, t. XVI, z. 4, s. 281-287.

Szczepaniak I., Krajowe i importowane surowce w produkcji żywności w Polsce, „Przemysł Spożywczy" 2017, nr 4, s. 2-5.

Szczepaniak I., Price advantages of Polish food producers in the European Union market, [w:] Ł. Ambroziak, M. Bułkowska, I. Szczepaniak, Assessment of the competitiveness of Polish food producers in the European Union, series „Multi-annual Programme 2011-2014”, nr 126.1, IAFE-NRI, Warsaw 2014, s. 102-115.

Szczepaniak I., Quality and price competition strategies in trade in agri-food products of Poland with the European Union, [w:] Ł. Ambroziak, M. Bułkowska, I. Szczepaniak, Assessment of the competitiveness of Polish food producers in the European Union, series „Multi-annual Programme 2011-2014”, nr 126.1, IAFE-NRI, Warsaw 2014, s. 86-101.

Szczepaniak I., Uwarunkowania zewnętrzne konkurencyjności polskich producentów żywności, [w:] I. Szczepaniak (red.), Konkurencyjność polskich producentów żywności i jej determinanty (1), seria „Monografie Programu Wieloletniego 2015-2019”, nr 11, IERiGŻ-PIB, Warszawa 2015, s. 50-66.

Szczepaniak I., Tereszczuk M., The improvement in the international competitiveness of the Polish food sector and its support with public funds during Poland's membership in the EU, [w:] A. Sorrentino, S. Severini i C. Cicatiello (red.), The Value of Food. Internazionalization, competition and local development in agro-food systems, Proceedings of the 52nd SIDEA Conference, Rome/Viterbo, September 17th - 19th, 2015, Rivista di Economia Agraria, vol. 71, nr 1 (Suppl.) - 2016, s. 134-143.

Sztompka P., Kapitat społeczny. Teoria przestrzeni międzyludzkiej, Wydawnictwo Znak, Kraków 2016.

Sztucki T., Promocja, reklama, aktywizacja sprzedaży, AW Placet, Warszawa 1995.

Ślusarczyk B., Międzynarodowa pozycja konkurencyjna Polski. Teoria i praktyka, Wydawnictwa Fachowe CeDeWu.PL, Warszawa 2011.

Świtoński M., Malepszy S., Postęp biologiczny w rolnictwie w erze genomiki i modyfikacji genetycznych, „Nauka” 2012, nr 1, s. 25-35.

Tangermann S., Direct Payments in the CAP post 2013, document requested by the European Parliament's Committee on Agriculture and Rural Development, IP/B/AGRI/IC/2011_003 PE 438.624, 2011.

Tereszczuk M., Ocena pozycji konkurencyjnej przemystu spożywczego w Polsce na tle wybranych państw Unii Europejskiej, [w:] I. Szczepaniak (red.), Konkurencyjność polskich producentów żywności i jej determinanty (2), seria „Monografie Programu Wieloletniego 2015-2019”, nr 38, IERiGŻ-PIB, Warszawa 2016, s. 93-121.

The competitive position of the European food and drink industry, Final Report, ECSIP Consortium, Luxembourg: Publications Office of the European Union, 2016. 
The Future of Food and Agriculture, Trends and Challenges, Food and Agriculture Organization of the United Nations, 2017.

The State of Food and Agriculture, Food and Agriculture Organization of the United Nations, Rome 2012.

The World Bank Annual Report 2008, http://siteresources.worldbank.org/EXTANNREP2K8/ Resources/YR00_Year_in_Review_English.pdf.

Tilman D., Balzer C., Hill J., Befort B.L., Global food demand and the sustainable intensification of agriculture, Proceedings of the National Academy of Sciences, 2011, nr 108(50), s. 20260-20264.

Tomczak F., Gospodarka rodzinna w rolnictwie: uwarunkowania i mechanizmy rozwoju, IRWiR PAN, Warszawa 2005.

Tran D., Nguyen N., Declining Productivity Gains and the Field Gap in Rice, [w:] M. Hall (red.), Farming Systems and Poverty, Improving farmers' livelihoods in a changing World, FAO and World Bank, Rome and Washington, D.C. 2001.

Trigo E.J., Veinte Años de Cultivos Genéticamente Modificados en la Agricultura Argentina 2016, http://argenbio.org/index.php?action=novedades\&note $=747$.

Układ o stowarzyszeniu między Unią Europejską i Europejską Wspólnotą Energii Atomowej oraz ich państwami członkowskimi, z jednej strony, a Gruzją, z drugiej strony, Dz. Urz. UE L 261/4 z 30.08.2014, http://eur-lex.europa.eu/legal-content/PL/TXT/PDF/?uri=CELEX:32014 D0494\&from $=$ PL.

Układ o stowarzyszeniu między Unią Europejską i Europejską Wspólnotą Energii Atomowej oraz ich państwami członkowskimi, z jednej strony, a Republiką Mołdawii, z drugiej strony, Dz. Urz. UE L 260/4 z 30.08.2014, http://eur-lex.europa.eu/legal-content/PL/TXT/PDF/?uri= CELEX:22014A0830(01)\&from=PL.

Układ o stowarzyszeniu między Unią Europejską i Europejską Wspólnotą Energii Atomowej oraz ich państwami członkowskimi, z jednej strony, a Ukrainą, z drugiej strony, Dz. Urz. UE L 161/3 z 29.05.2014, http://eur-lex.europa.eu/legal-content/PL/TXT/PDF/?uri=CELEX: 22014A0529(01)\&from=PL.

Urban R., Czynniki wzrostu konkurencyjności polskiego przemystu spożywczego, „Zagadnienia Ekonomiki Rolnej" 1999, nr 2-3, s. 20-30.

USDA, Economic Research Service using agricultural yield survey data form USDA, National Agricultural Statistics Service, 2013.

Ustawa z dnia 22 maja 2009 roku o funduszach promocji produktów rolno-spożywczych (Dz.U. z 2009 r., nr 97, poz. 799).

Vollrath T.L., A theoretical evaluation of alternative trade intensity measures of revealed comparative advantage, „Weltwirtschaftliches Archiv” 1991, nr 130, s. 265-279.

Wasilewska A., Wasilewski M., Stan, kierunki i efektywność innowacji w przedsiębiorstwach przetwórstwa rolno-spożywczego, Wydawnictwo SGGW, Warszawa 2016.

Wicka A. (red.), Uwarunkowania ograniczania ryzyka w produkcji roślinnej z wykorzystaniem ubezpieczeń, Wydawnictwo SGGW, Warszawa 2013.

Wicki L., Efekty upowszechniania postępu biologicznego w produkcji roślinnej, Wydawnictwo SGGW, Warszawa 2010. 
Wicki L., Postęp $w$ plonowaniu odmian pszenicy ozimej $i$ żyta $w$ doświadczeniach odmianowych w Polsce, „Roczniki Naukowe Stowarzyszenia Ekonomistów Rolnictwa i Agrobiznesu” 2017, t. XIX, z. 4, s. 224-230.

Wicki L., Wykorzystanie potencjatu plonowania zbóż w produkcji rolniczej w Polsce, ,Roczniki Naukowe Stowarzyszenia Ekonomistów Rolnictwa i Agrobiznesu” 2016, t. XVIII, z. 5, s. 267-273.

Wicki L., Zmiany w zużyciu nasion kwalifikowanych w Polsce, „Roczniki Nauk Rolniczych. Seria G” 2009, t. 96, nr 4, s. 226-237.

Wicki L., Dudek H., Wpływ podstawowych nakładów plonotwórczych na poziom i wartość produkcji w gospodarstwach rolniczych, „Roczniki Nauk Rolniczych. Seria G” 2005, t. 92, nr 1, s. 30-41.

Wieś polska - charakterystyka ludności rolniczej, Komunikat z badań CBOS, BS/138/2013, Warszawa, październik 2013.

Wigier M., The competitiveness of Polish agriculture after accession to the EU, „Economics of Agriculture” („Ekonomika Poljoprivrede”, Belgrade) 2014, vol. 61, nr 1.

Wijnands J.H.M., Verhoog D., Competitiveness of the EU food industry. Ex-post assessment of trade performance embedded in international economic theory, LEI Wageningen UR, February 2016.

Wiktor J.W., Promocja. System komunikacji przedsiębiorstwa z rynkiem, Wydawnictwo Naukowe PWN, Warszawa 2006.

Wilkin J., Współczesna kwestia agrarna, PWN, Warszawa 1986.

Wirkung von Lebensleistung und Nutzungsdauer der Kühe auf die Ökonomie der Milchproduktion, Thüringer Landesanstalt für Landwirtschaft, Jena, Juni 2008.

World Economic Forum, The Global Competitiveness Report 2017-2018, http://reports.weforum. org/global-competitiveness-index-2017-2018/.

World Trade Statistical Review, World Trade Organization 2017, https://www.wto.org/english/ res_e/statis_e/wts2017_e/wts2017_e.pdf.

Woś A., Prognoza przekształceń strukturalnych polskiego rolnictwa do 2020 roku, IERiGŻ, Warszawa 1996.

Woś A., Rachunek ekonomiczny w rolnictwie, PWRiL, Warszawa 1966.

Wójcicki Z., Szeptycki A., Efektywność postępu technicznego w modelowych gospodarstwach rodzinnych, „Problemy Inżynierii Rolniczej” 2016, z. 4(94), s. 5-18.

WRI Annual Report 2013, http://www.wri.org/sites/default/files/WRI_2013_Annual_Report fulldraft_100314.pdf.

WTO Trade Review Statistics 2017.

WTO, World Tariff Profiles 2016.

Ziętara W., Adamski M., Konkurencyjność polskich gospodarstw mlecznych i z chowem bydła rzeźnego na tle analogicznych gospodarstw z wybranych krajów, Prezentacja z seminarium IERiGŻ-PIB, Warszawa, 13.10.2017.

Ziętara W., Adamski M., Skala produkcji, efektywność i konkurencyjność polskich gospodarstw wyspecjalizowanych w produkcji mleka, „Zagadnienia Ekonomiki Rolnej” 2014, nr 1, s. 97-115.

Zintegrowana Taryfa Celna UE (TIRAC 2017), http://ec.europa.eu/taxation_customs/dds2/taric/ taric_consultation.jsp?Lang=en\&SimDate $=20170101$. 


\section{EGZEMPLARZ BEZPLATNY}

Nakład 650 egz., ark. wyd. 14,6

Druk i oprawa: ZAPOL Sobczyk Spółka Jawna 